


$$
\text { ชै }
$$




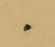







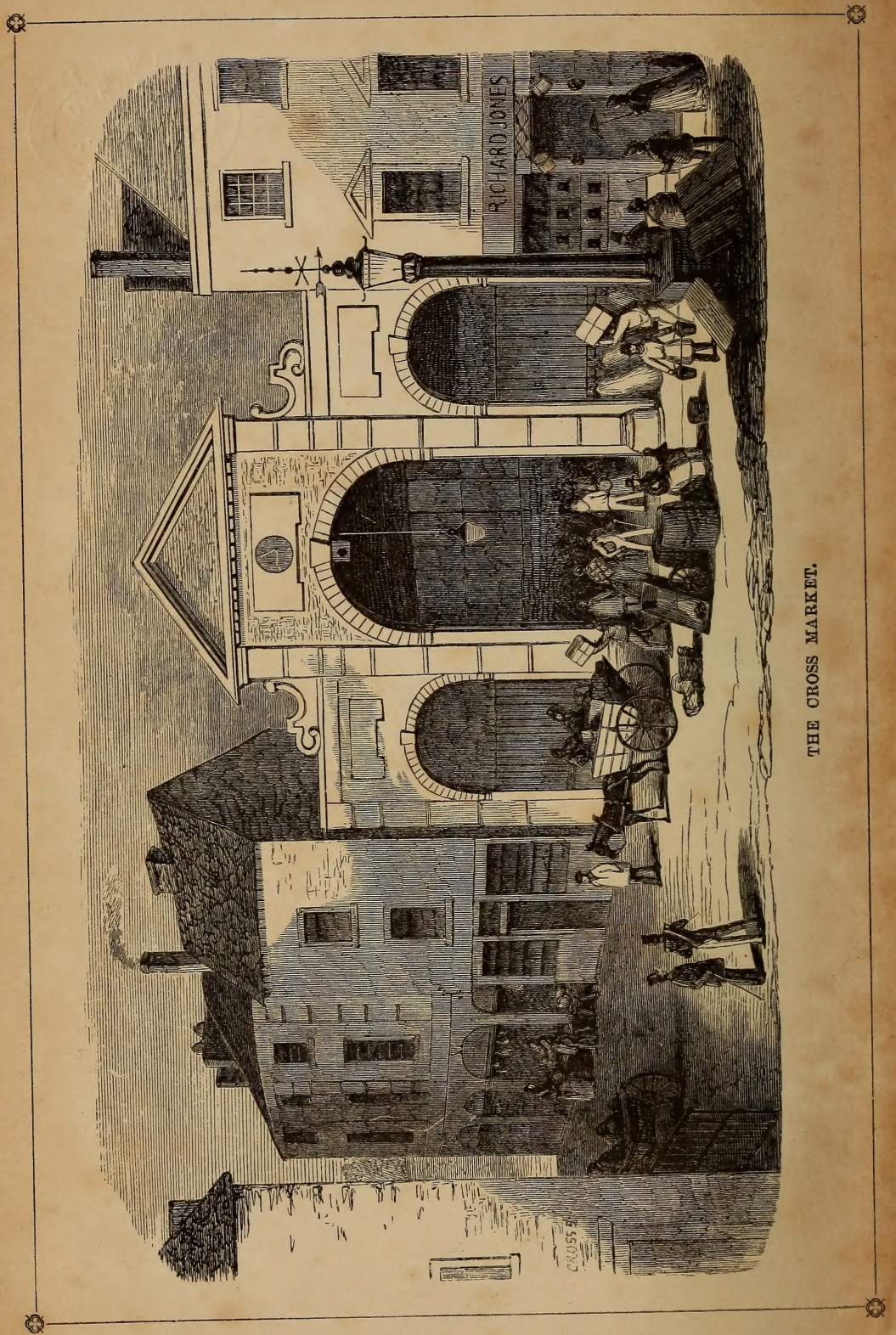


THE

\section{HISTORY OF OSWESTRY,}

COMPRISING THE

BRITISH, SAXON, NORMAN, AND ENGLISH ERAS;

THE

TOPOGRAPHY OF THE BOROUGH; AND ITS

ECCLESIASTICAL AND CIVIC HISTORY:

WITH NOTICES OF

BOTANY, GEOLOGY, STATISTICS, ANGLING, AND BIOGRAPHY:

TO WHICH ARE ADDED

\section{SKETCHES OF THE ENVIRONS.}

ILLUSTRATED WITH WOOD-ENGRAVINGS,

By MR. PERCY CRUIKSHANK, after Sketches by MR. ROBERT CRUIKSHANK.

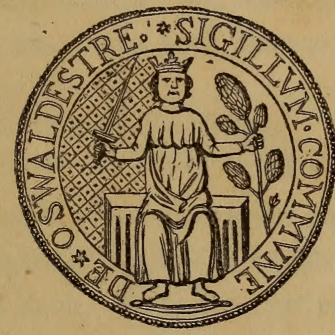

WRITTEN AND COMPILED

\section{BY WILLIAM CATHRALL,}

AUTHOR OF "THE HISTORY OF NORTH WALES," “WANDERINGS

IN NORTH WALES," \&c.

OSWESTRY :

PRINTED AND PUBLISHED BY GEORGE LEWIS.

ENTERED AT STATIONER' HALI. 


$$
5487.02
$$

$$
\begin{aligned}
& \text { DA690 } \\
& .08 \mathrm{C}^{3}
\end{aligned}
$$




\section{解retinter.}

The issue of this volume has been "the accident of an accident." I was called by commercial business last autumn to Oswestry, where I found, temporarily Iocated, a man with humour at his finger-ends, and of "infinite jest" on paper. I allude to Mr. Robert Cruikshank, an artist scarcely inferior to his celebrated brother, Mr. George Cruikshankpar nobile fratrum, who have both successfully laboured in their vocation to

"Shoot folly as it flies,

And catch the living manners as they rise."

Mr. Robert Cruikshank, pleased with the rich and diversified scenery of the neighbourhcod of Oswestry, undertook to illustrate the present book. To be thus pictorially aided was a distinction, and I therefore cheerfully complied with the wish of the respectable publisher, to try my "'prentice hand" at a History of the Borough. Mr. Cruikshank has well executed. his task. What may be my portion of merit will be determined by the judgment, not critically severe, I hope, of my readers.

The History of Oswestry and its neighbourhood is, however, worthy of a more elaborate and carefully-wrought 


\section{PREFACE.}

volume than that which I now send forth; and I should have been glad had some pen, abler than my own, been employed in the completion of so desirable a work. Oswestry is not deficient in the talent or learning necessary to produce a voluminous history; but until the historic mantle fall upon some kindred spirit, that can evoke with magic skill the dramatis personce and chequered incidents of bye-gone ages, and beguile his readers with beautiful delineations of his native hills and vallies, the good citizens of Oswestry must, I fear, content themselves with the present volume, whose chief excellence, if it possess any, may be found to consist in supplying a collection of interesting facts, connected with the town and district, hitherto dispersed through many publications.

In preparing this volume for the press much delay has occurred from the pressure of other and more anxious engagements. In wading, however, through musty tomes and modern books, I have been instructed and solaced by the way. The Past reveals little else than vandal darkness and the pride and pomp of feudal power. Lords and their vassals figure chiefly in the discordant scene, and ignorant dependence is too commonly seen prostrate at the feet of favourites, in court or field, of ambitious and despotic monarchs. The Present has a more genial and encouraging aspect. Religion, with her gentle handmaids, Literature, Science, and Art, is shedding its radiance even over this district, so long the theatre of Border-feuds, strife, and injustice. The Future, therefore, indicates still more agreeable promise; and those of the present generation who are co-operating in the good work already begun, of endeavouring to make the world better than they found it, will have the consolation of leaving to posterity an inheritance more precious than silver or gold. 


\section{PREFACE.}

I cannot close these remarks without thankfully acknowledging the assistance $I$ have derived, from several gentlemen of the town and neighbourhood, in the prosecution of my labours. If I could have stirred up many others to the grateful task of elucidating the history of their native or adopted place of residence, I should have been still more satisfied. I take this opportunity of mentioning the names of The Rev. Thomas Salwey, Vicar of Oswestry, Richard Redmond Caton, Esq., F. S. A., Edward Williams, Esq., of Lloran House, R. J. Croxon, Esq., Charles Sabine, Esq., and one or two other gentlemen, who, with a becoming feeling of respect for the ancient borough, have kindly aided me by various contributions.

I am sensible of many imperfections in the volume; but I trust, by the generous support of the Public, I may be enabled, at some not far distant day, to revise my pages, and render them still more worthy of acceptance.

\section{WILLIAM CATHRALL.}

Oswestry, October, 1855. 


\section{LIST OF SUBSCRIBERS.}

Asterley Miss, Willow-street Attree R. W., Esq., Plasmadoc

Bassett Joseph, Esq., solicitor Berry Joseph, Accountant Bennion Edward David, Esq., Summer Hill

Baugh Robert, Llanymynech

Bull William Isaac, Esq., solicitor

Bickerton George Morrel, brazier

Bartlett Charles Archibald, 32, Paternoster Row, London

Buckley Miss Eliza

Broughall John, Esq., Fernhill, Whittington

Barlow Thomas, Esq., postmaster, Worksop

Barnes William, Osberton Hall, Notts

Bayley Joseph, Quadrant

Casher Rev. Frederick, Incumbent of Trinity Church

Corbett Vincent, Esq.

Caton Richard Redmond, Esq., F.S.A.

Croxon Richard Jones, Esq., Town Clerk

Crutchloe Henry, Lloran Cottage

Cooper George, Esq., Salop-road

Cullis William, Lower Brook-st.
Corney William, confectioner and spirit merchant

Churchill Benjamin, Esq., Bellan House

Cross Thomas, Ornithologist

Cox J., porter merchant, Birmingham

Clarke Mrs., 3, Devonshire-terrace, Paddington, London

Cruikshank Percy, Pentonville, London

Churchill Miss, Bellan House (2 copies)

Crippin R., Church-street

Cross William B., Cross-street

Cartwright Samuel, Abbey Foregate, Shrewsbury

Donne Rev. Stephen, the Schools (12 copies)

Dovaston John, Esq., Nursery, West Felton

Davies Henry, Esq., solicitor

Davies John, draper

Davies Edward, confectioner

Davies Captain, Llanymynech

Dicker Phillip Henry, Esq., surg.

Davies Messrs. R. \& W., Golden Eagle

Downes Richard, Esq., Haughton Grange 


\section{LIST OF SUBSCRIBERS.}

Davies Edward, Esqu, surgeon, Llansilin

Davies Henry, schoolmaster, Llandrinio

Duckett Mrs. Tamar, the Lodge

Davies Mrs. E., Chirk

Duncan John, Esq., solicitor, 2, New Inn, Strand

Davies W. M., Waterloo-house

Davies Giles, Lower Brook-street

Davies Thomas, Greenwich

Davies John, Erwallo, Glyn

E DWARDS James, Esq., Upper Brook-street (2 copies)

Edmunds Rev, Edw., M.A., Vicar of St. Michael's, Southampton

Eddy Walter, Mine Agent, Fron, Rluabon

Evans Edward, auctioneer

Edwards Thomas, Esq., Cae Glas

Edwards Ed., Commercial Hotel

Eyeley Edward, organist

Evans R. D., Esq., Meifod

Edwards James Coster, Trefynant

Edwards Thomas, chandler

Evans John, ship builder, Morbum, Machynlleth

Edwards Alfred, Hanwell, Middlesex

Edmunds Griffith, Albion Hill

Edisbury James, Esq., Wrexham

Edisbury J. F., Esq., Holywell

Ellis Henry, English Walls

Evans Edward, Liverpool Gas Co.

Evans William, Glascoed

Edwards Edward, currier

Edwards William, Queen's Head

Evans John, Church-street

Ewing John, gardener, Osberton Hall

Fitz-William, The Right Hon. The Earl (4 copies)

Fitz-William, The Hon. Lady Charlotte Wentworth, Wentworth House

Fitz-William, The Hon. M, S. C. Wentworth

Fitz-William, The Hon. Lady Dorothy H. Wentworth

Francis Captain, Aberystwith

Fallon Rev. J. M., Ballee Rectory, Ireland
Fuller William, Esq., Salop-road

Furnin The Rev. J. P., Rode Parsonage, near Lawton, Cheshire

Faulder F. J., Esq., St. Ann'ssquare, Manchester

Fox John, accountant

Gore William Ormsix, Esq., M.P. for North Shropshire

Grey William, Esq., New Burlington-street, London

Gray Thos., Esq. architect, Chester

Greenwood J. W., Esq., London

Goodwin John, Beatrice-street

Galloway Charles, Halston

George Roger, Willow-street

Giles Henry, Cross-street

Gornall Mrs. Jane, Swan Inn

Griffiths William, Esq., solicitor, Dolgelley

Hill The Right Hon. The Viscount, Lord Lieutenant of the County of Salop

Hales John Miles, Esq., Lower Brook-street

Hill T. Esq., Upper Brook-street

Hill T. W., Esq., Upper Brook-st

Hargraves James, Esq., Whittington ( 2 copies)

Hayden Wm. Henry, 17, Warwick-square, London

Higgins Samuel, draper

Holland George, Whittington

Husband Rev.J., Rectory, Selattyn

Hopwood F. A., Station Master, Gobowen

Hardman Thomas, 14, Slaterstreet, Liverpool

Hughes T., Esq., solr., Wrexham

Hughes Miss Catherine, Churchstreet

Hughes Alexander, Willow-street

Hughes Miss Anne, Salop-road

Humphreys Edmund, East Sheen, Richmond ( 2 copies)

Hughes John, Savings' Bank

Hilditch George, Esq., Salop-road

Heaton Rev. H. E., M.A., perpetual curate of Llangedwin

Hodgkinson R., Esq., estate agent, Osberton, Worksop

Howell David, Willow-Street (2 copies) 


\section{LIST OF SUBSCRIBERS.}

Hughes Thos., Esq., Plasnewydd, Llansilin

Jones, Rev. Llewelyn Wynn, M.A., Curate of Oswestry (2 copies)

Jacob Rev. L. R., Rhuabon

Jones John, Esq., solicitor

Jones Miss Harriette, Church-st.

Jones Thomas, Esq., Boughton, Chester

Jones Joseph, wine merchant

Jones Edward, Plas Issa, Rhuabon

Jones Mrs. Frances, London House

Jones John, hair dresser

Jones Edwin, Union-place

Jones James Thomas, Esq., Brynhafod ( 2 copies)

Jones Oswald Croxon, Esq., Enfield, Middlesex

Jones Mrs. Mary Watkin, Crossstreet

Jacques Edwin William, Esq., Llangollen

Jones Henry, tobacconist

Jones Thomas, Esq., Brook-street

Jones John, Esq., Domgay, Llandisilio

Jeryis Geo. Boot Inn, Whittington

Jones Rev. D. L., Meifod

Jones Rev. Walter, Llansilin

Jones Richard, Cross-street

Jones Richard, Salop-road

Jones Thomas, builder, Chester

Jones Gwen, Cross-street

Jones Henry, grocer, Cross-street

Jones John Pryce, Willow-street

Jones John, Cross

Jones Richard, Esq., Bellan Place, Rhuabon

Jones Edward, Mine Agent, Llwynymapsis

Kenyon John Robert, Esq., Recorder of Oswestry

Kinchant Richard Henry, Esq., Park Hall

King John Edward, Cross Keys Hotel

Kilner Richard, Brittania Inn

LovetT Joseph Venables, Esq., Belmont

LLoyd, Mrs., Aston Hall
Longueville Mrs., Pen-y-lan

Longueville Thomas Longueville, Esq.

Lloyd Rev. Albany Rosendale, Hengoed

Large Joseph, Esq., surgeon

Lewis Richard, Osberton Hall, Notts (4 copies)

Lloyd David Edward, Cross

Lloyd David, Wynnstay Arms Hotel

Lewis Charles Thomas, 38-9, Holloway Head, Birmingham (6 copies)

Lewis Henry, painter, Beatrice-st.

Lloyd Rev. David, Trefonen

Lewis William, Elephant and Castle, Newtown

Leah John, Esq., Willow-street

Lewis Henry, building surveyor $\&$ contractor, Chester ( 2 copies)

Lever William H., Esq., Chirk

Lewis Miss Margaret, Cross

Lees S. S., National Schools

Lyons Aaron, Jeweller, Leg-street

Lloyd Miss M. A., Willow-street

Milton The Hon. Viscountess, Osberton, Notts

Milton The Hon. Selina, Viscountess, Osberton Hall, Notts

Mickleburgh Chas. Esq., Montgomery ( 2 copies)

Minshall Thomas, Esq., solicitor

Morris Edward, Esq., Salop-road.

Morris William, builder

M'Kie William Hay, Scybor Issa

Morgan Captain, 54, Terrace, Aberystwith

Minett William, Esq., Maesbury

Meredith Edward, Rednal

Morris Joseph, Esq., Shrewsbury

Morgan John, Wynnstay

Moreton and Son, Cross

Morgan Thomas, Willow-street

Mytton John, Church-street

Manning Benjamin, Esq., Warwick-square, London

Martin John, Esq., Gold Mine, Dinas Mowddy (3 copies)

Monk Charles, Llangollen

Morris George, Porkington

Morgan R., A berystwith 


\section{LIST OF SUBSCRIBERS.}

M'Kie William H., Melbourne, Australia

Morris John, builder (2 copies)

Morris Thomas, chemist, Worksop, Notts

Norfolk The Most Noble His Grace the DuKe of (Baron of Oswestry), Arundel Castle, Sussex (4 copies)

Nicholson J. Esq., Upper Brookstreet

Oswell Edward, Esq., solicitor

Owen M. Wynne, Esq., Plas Wilmot

Owen George, Esq., Park Issa (2 copies)

Oliver Irwin, Leg-street

Owen Elizabeth, 5, Upper Parade, Leamington

Oliver John, druggist, Liverpool

Powis The Right Hon. the EARL OF (Lord of the Manor of Oswestry), Powis Castle

Portman The Right Hon. Lord, Bryanstone House, Dorset

Portman The Hon. William Berkeley, M. P.

Phillips John, Esq., Cross

Porter Isaac, Esq., Salop-road

Pryce Thomas, Cross-street

Powell John Richard, Esq., Preesgwene

Price William, Esq., Fulford, York

Phillips the Rev. John Croxon, Tynyrhos

Pearson Mr. S., clothier, 2, Lamb's Conduit-street, London

Penson Richard Kyrke, Esq., Willow-street

Price Miss Mary, The Cross

Phillip and Son Messrs., Liverpool

Penson'Thomas M ainwaring, Esq., Chester

Price Miss Elizabeth, Confectioner, Cross

Peate Jane, Porkington Terrace

Pierce Mrs. H., 87, Park Terrace, Green Heys, Manchester

Perkins Samuel, Bailey Head

Pearson W., J. Munn and Co., Manchester (4 copies)
Powell William, Salop Road

Parry Thomas Price, Willow-st.

Provis William A., Esq., Crossstreet

Pearce R.A., Esq., Worksop, Notts

Rogers Thomas, Esq., Stone House

Roberts Thomas Vaughan, Esq., solicitor

Roberts Thomas, Esq., Glyndwr, St. Asaph

Roberts John, Esq., Cross-street

Roberts Maurice, draper

Roberts David, Leg-street

Rogers E., Church-street

Roberts John Askew, Bailey Head

Rodenhurst Charles, Whittington Roderick William, Esq., surgeon

Redrobe James, Royal Oak

Roberts Miss, Brook-st. Cottage

Roberts R., gas proprietor

Roberts E., Willow-street

Roberts William Whitridge, Melbourne, Australia

Reed Mrs., London

Ruscoe John, Horse Shoe Inn

Salwey Rev. Thomas, Vicar of Oswestry

Sabine Charles, Esq., solicitor

Smith Frederick William, Esq., Ruthin (3 copies)

Smale William, chemist

Sharwood Messrs, S. and T., 120, Aldersgate-street, London (2 copies)

Saunders George James, chemișt Sage Mrs. Catherine, Middletonroad

Smith Captain, Dinas Mowddy

Smith Henry, Supervisor, Inland Revenue

Savin Thomas, draper

Stokes Mrs., Rock Ferry

Sides Miss Sarah, Fron, Rhuabon

Sissons Henry, stationer, Worksop, Notts

Shaw Henry, ironmonger, Worksop, Notts

Smith Benjamin, innkeeper, Norton, Notts 


\section{LIST OF SUBSCRIBERS.}

Tipton Edward Blakeway, Esq., Distributor of Stamps for Shropshire and North Wales

Thomas Edward Wynne, Esq., Cross

Tomkies John, Esq., Manchester (2 copies)

Thomas Rev John, Liverpool

Thomas John, maltster

Tucker St. Felix, Esq, H.M.C., West Derby-road, Liverpool

Taylor John, shoemaker

Tyley Thomas, Sun Inn

Thomas Henry, Coney Green

Thompson John, Leg-street

Towers Mr., Angel Hotel, Dalestreet, Liverpool

Thompson Thomas, Chester

VenablesRowland Jones, Esq., Oakhurst

Vaughan Robert Chambre, Esq., Burlton, Shrewsbury

Venables Mrs. Eliz., Whittington

West Frederick Richard, Esq. M.P., Ruthin Castle

West Frederick Myddleton, Esq. Williams Edward, Esq., Lloran House ( 4 copies)
Wilding John Powell, Esq., Montgomery

Whalley George Hammond, Esq., Plasmadoc

Waite George, Esq., New Burlington-street, London

Williams Rev. Rt., Rhydycroesau

Webster Benjamin Esq., Adelphi Theatre, Strand, London

Wood Richard, Leg-street

Woods Richard, farmer, Osberton, Worksop

Williams J. Vincent, Accountant

Wright Edmund, Esq., Halston

Wynn Edward, Black-gate

Williams Edward, Belle Vue, Wrexham

Williams Rt., draper (2 copies)

Williams Samuel, The Llys

Winter John, Chirk

Webb Miss J. C., Melbourne, Australia

Windsor William, Babin's Wood

Windsor Samuel, Powis Castle

Wilson William, upholsterer

Williams G. H., Esq., The Lymes

Williams William, Esq., 295,

Kent-St., Southwark, London

Williams Michael, Railway Station

Whitridge Mr, bookseller, Carlisle 


\section{学位政。}

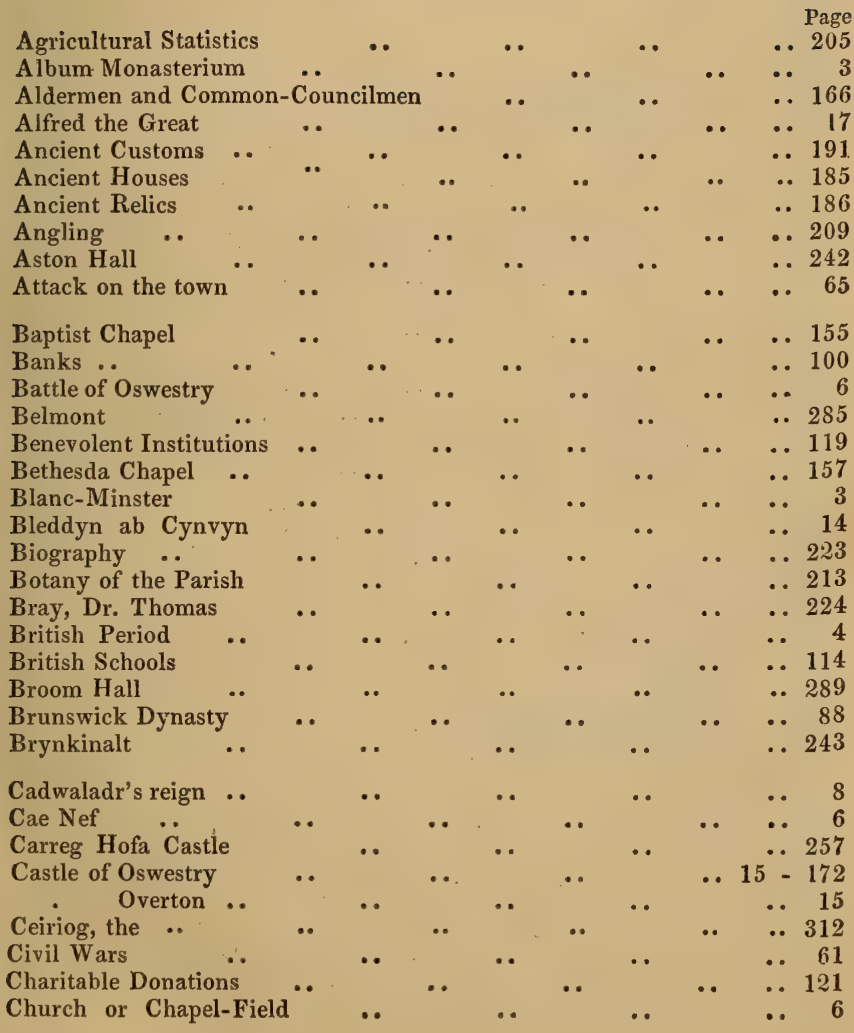


INDEX.

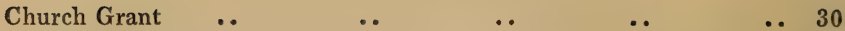

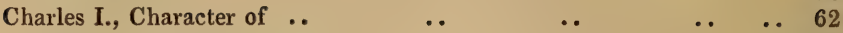

$\begin{array}{lllllll}\text { Charter, First Royal } & \text {. } & & \ldots & \ldots & \ldots & \\ \text { Charter }\end{array}$

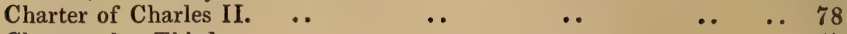

$\begin{array}{llllll}\text { Charter the Third } & \ldots & \ldots & \ldots & \ldots & 47\end{array}$

Chirk

Chirk Castle

Clawdd Coch

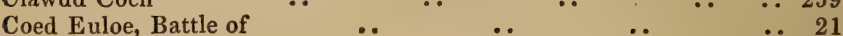

$\begin{array}{lllllll}\text { Cranage's Daring } & \ldots & \ldots & \ldots & \ldots & \ldots & 66\end{array}$

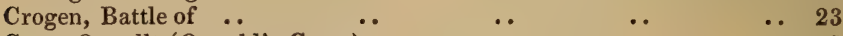

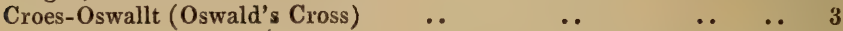

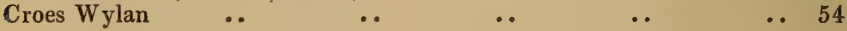

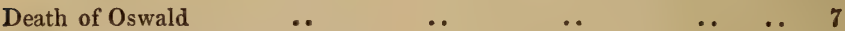

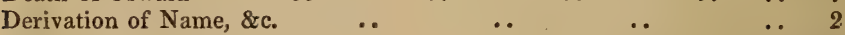

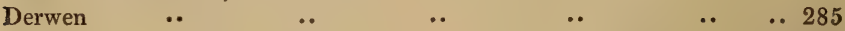

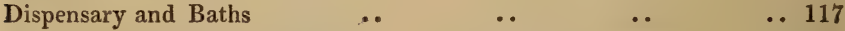

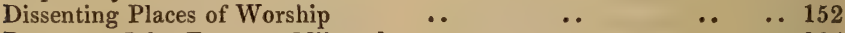

Dovaston, John Freeman Milward _ _ $\quad$. $\quad$.. 224

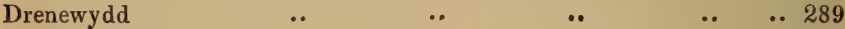

$\begin{array}{llllll}\text { Ecclesiastical History } & \ldots & \ldots & \ldots & \ldots 132\end{array}$

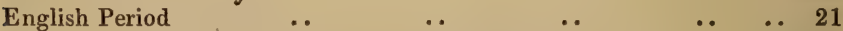

Extension Line (Oswestry and Newtown) Railway _. $\quad$.. 198

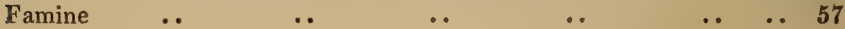

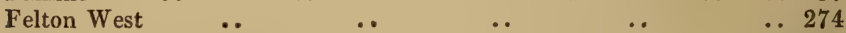

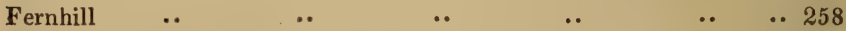

$\begin{array}{lllllll}\text { Fitz-Alan, William } & \ldots & \ldots & \ldots & \ldots & \ldots & 15\end{array}$

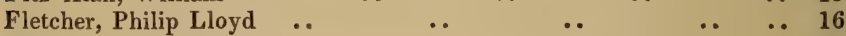

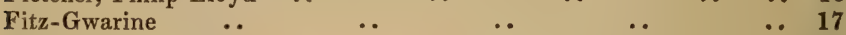

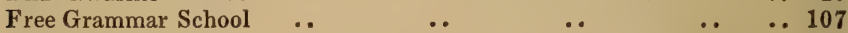

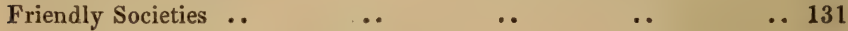

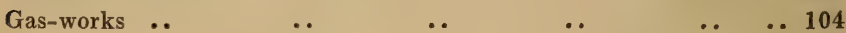

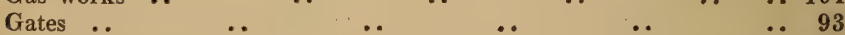

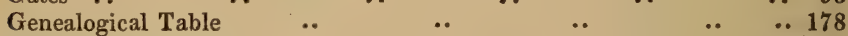

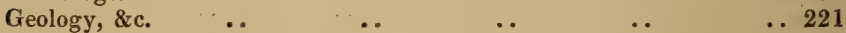

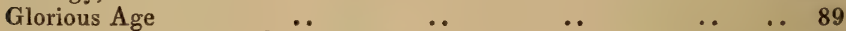

$\begin{array}{llllll}\text { Glyndwr Insurrection } & \ldots & \ldots & \ldots & \ldots & \\ \end{array}$

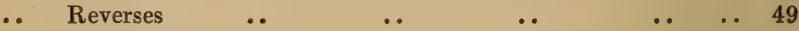

$\begin{array}{lllllllllll}\text {.. } & \text { Death of .. } & \ldots & & \ldots & & \ldots & & \ldots & 50\end{array}$

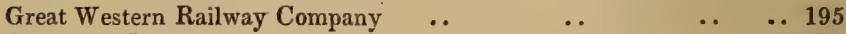

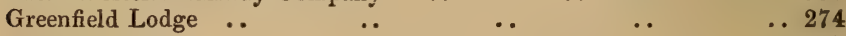

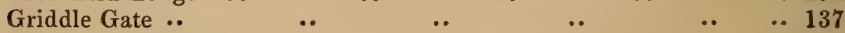

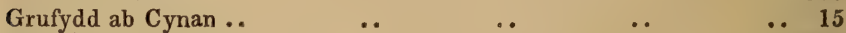

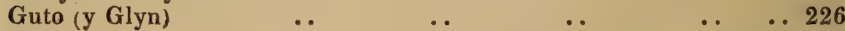

$\begin{array}{llllllll}\text { Halston } & \ldots & & \ldots & & \ldots & & \\ \end{array}$

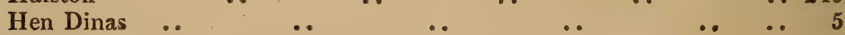

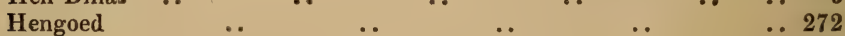

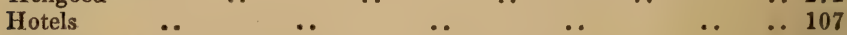

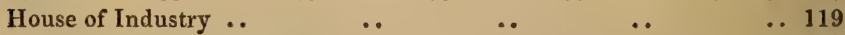

Humphreys, Humphrey, D.D. $\quad \ldots \quad$.. $\quad \ldots \quad \ldots 227$ 


\section{INDEX.}

Huntington, Execution of. .

Hywel Dda (the Welsh Justinian)

.. 35

.. 13

Independent Methodist Chapel

Ingratitude of (Common Wealth) Parliament

.. 157

Invasion of Wales

.. 73

.. 21

Jones, Thomas

.. 227

King Oswald..

Knockin

.. 5

.. 253

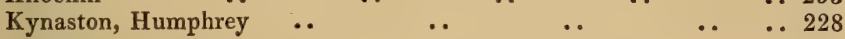

Le Strange, Roger ..

Lighting

Lodge, the

Llanforda

Llangollen Vale

Llanymynech

Llanyblodwel

Llansilin

Lloyd, Colonel

Lloyd, Bishop

Llynclys (or Llynclis) Pool

Lupus, Hugh

Llwyd, Edward

Llywarch Hen

Llywelyn ab Jorwerth

.. 17

.. 96

.. 273

.. 260

.. 292

.. 254

.. 262

.. 261

.. 63

.. 83

.. 211

.. 16

.. 230

.. 8

.. 27 .

Madog

Maelor

Marrow's Assault

Marches Lordships .

Margery Bruce

Markets and Fairs ..

Markets

.. 15

.. 15

.. 69

.. 17

.. 180

.. 97

102-3

Maserfield

Mathrafal

Maud Verdon

Maurice, William

Mayors, List of

Mayor's Blunders

Mediolanum

Montgomery, Roger de .

Morda, the

Morlas, the

Morus, Hugh

Monuments within the Church

.. 7

... 9

.. 15

.. 231

.. 164

.. 85

.. 259

.. 16

.. 212

.. 212

.. 231

.. 139

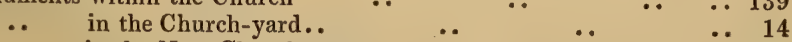

Morva Rhuddlan

in the New Church-yard ..

Mortimers, the

Mount Pleasant

Municipal and Civil Government

.. 147

.. 113

.. 31

.. 290

.. 158

.. 163 
INDEX.

Murage, the

Myddelton, Sir Thomas .. Mytton, Major-General

Mytton, the late John, Esq.

National Schools

Natural History

Newport, Mr.

Norfolk, Duke of

Norman Period

Notabilia

Oakhurst

Offa's Dyke

Old Chapel ..

Oswald's Well

Oswestry Race-course

.. Castle, Burning of

.. Government of ..

.. As it was ..

.. recent History of

. Castle Hill

Owain Brogyntyn

Oswald and Penda

Parliament, the Great

Parish Church

., Sunday School

Park Hall

Penda, the Mercian King

Pengwern

Pentre Pant

Pentre Poeth

Penylan

Perry, the

Plague, records of ...

Plot to remove the markets

Poor Rate Return-Oswestry town and parish (1855)

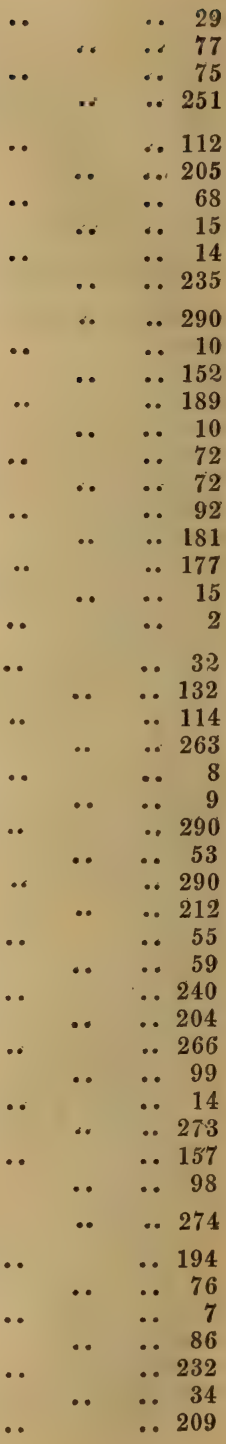

Population ..

Porkington

Post Office

Powys Vadog

Preesgwene House

Primitive Methodist Chapel

Public Establishments and Institutions

Quinta, the .

Railway Communication

Restoration, the

Review of Ancient History

Revolution, the

Reynolds, John

Richard II., death of

Rivers.. 


\section{INDEX.}

Rhyd-y-croesau

Rhyd-y-croesau Church ..

Roberts, the Rev. Peter

Rug

Sacheverell, Dr

Salter, Mr. Robert

Savings' Bank

Saxon Period

Selattyn

Shrewsbury, the Battle of..

Siarter Cwtta, the Short Charter

Site of the town

Sketches of the Environs of Oswestry

. 290

.. 150

.. 232

.. 15

Social Improvement..

Society for Bettering the Condition of the Poor

Spot, Dick

St. Martin's

Stamp Office

Statistics

Streets

Sweeney Hall

.. 86

.. 234

.. 101

.. 9

.. 269

.. 37

.. 24

.. 91

.. 241

.. 88

.. 129

.. 233

.. 272

.. 101

.. 201

.. 95

.. 291

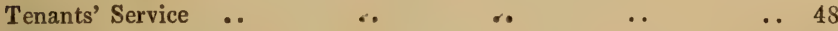

Theatre

. 104

.. 90

.. 184

Town Walls ..

Tre'r Cadeiriau

Tre'r Fesen .

Trefaldwyn

Trefonen Church

Tre Meredydd

Trevor, Sir John

Trinity Church

Tyn-y-Rhos

Visit of Baldwin and Giraldus ..

. 3

.. 6

.. 13

. 149

.. 14

.. 159

.. 144

.. 278

Vicars, List of

.. 25

.. 151

Walter the Stewart

.. 179

Watt's Dyke

$1-12-13$

Welsh Cloth Market

.. 51.

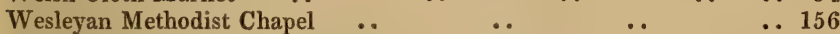

Whittington ..

William the Conqueror

Wood Hill Hall

Wynnstay

Young Men's Institute

Zion Chapel..

.. 275

.. 10

.. 291

.. 286 


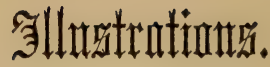

\section{THE TOWN.}

Beatrice Gate ...

Church Gate and Arenue...

Corn Market and Street Views

Dispensary and Public Baths

Free Grammar School

Griddle Gate ...

New Gate

National Schools

try Castle (from an ancient drawing belonging

Dudleston)

The Old Chapel

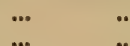

Parish Church...

... $\quad$...

Powis Market, Guildhall, and Bailey Head

St. Oswald's Well

Trinity Church...
...

...

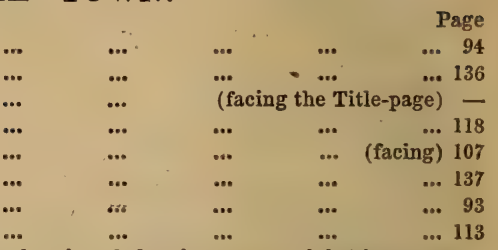

... (facing) 172

... ... 155

... (facing) 132

... (facing) 103

... $\quad$... 190

$\ldots \quad \ldots 148$

\section{THE ENVIRONS.}

$\begin{array}{llllllll}\text { Brynkinalt } & \ldots & \ldots & \ldots & \ldots & \ldots & \ldots & \text { (facing) } 243 \\ \text { Chirk Castle } & \ldots & \ldots & \ldots & \ldots & \ldots & \ldots & \text { (facing) } 244 \\ \text { Halston } & \ldots & \ldots & \ldots & \ldots & \ldots & \ldots . & \text { (facing) } 249 \\ \text { Llanymynech } & \text { Church } & \ldots & \ldots & \ldots & \ldots & \ldots & \ldots 2255 \\ \text { Park Hall } & \ldots & \ldots & \ldots & \ldots & \ldots & \ldots & \text { (facing) } 263 \\ \text { Porkington } & \ldots & \ldots & \ldots & \ldots & \ldots & \ldots & \text { (facing) } 266 \\ \text { Selattyn Church } & \ldots & \ldots & \ldots & \ldots & \ldots & \ldots 2 \\ \text { Whittington Castle } & \ldots & \ldots & \ldots & \ldots & \ldots & \text { (facing) } 281 \\ \text { Wynnstay } & \ldots & \ldots & \ldots & \ldots & \ldots & \ldots & \text { (facing) } 287\end{array}$




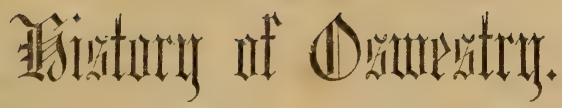

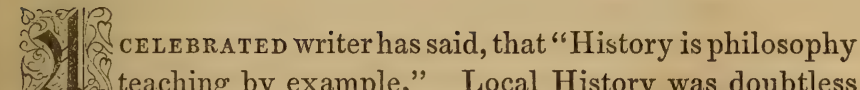
included in the reflection of the distinguished essayist, when he penned the memorable sentence, which has for years past been adopted as a national maxim. In Local History we have handed down to us facts and fiction, both grave and gay ; traditions and customs illustrative of popular habits and manners; records of national edicts and social laws; municipal mandates, and parochial practice; doleful notes of superstition and ignorance, with gratifying statistics of the progress of truth and enlightenment; pleasing reports of the advancement of science and art, mechanical ingenuity, and industrial pursuits ; and, speaking comprehensively, with a keen glance at the past, we descry enough, in the chequered examples of byegone times, to help us on in wisdom's ways.

With these preliminaries, let us now lead our readers pleasantly onward through the devious paths and labyrinths of Oswestry's varied history, beguiling them, perchance, by the way, with all that is agreeable pertaining to the Ancient and Loyal Borough, which, from its antiquity, its scenes of martial daring and prowess, the tranquil beauty of its surrounding landscapes, and its primitive, as well as modern 


\section{HISTORY OF OSWESTRY.}

relation to some of the sweetest spots of CAMBRIA, has commanded the admiration and homage of historians, painters, and poets.

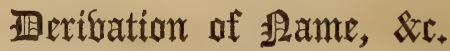

The derivation of the name of the Borough is still, and perhaps ever will be, involved in obscurity. As a place of retreat for the Cymry, or early Britons, when chased from the south by the Roman invaders, it is not unlikely to have had a primitive name that has been lost in the flood of ages. Pennant, whose industry and historical research have earned for him lasting fame, dates the commencement of its history in the Saxon period, not anterior to the celebrated conflict at Oswestry between Oswald, the Christian King of the Northumbrians, and Penda, the Pagan King of the Mercians, which occurred in the year 642. Other Welsh biographical and historical writers trace the origin of its name to a much earlier period, and contend that Oswal, a son of Cunedda Wledig, sovereign of the Stratclyde Britons, and who lived in the early part of the fifth century, received from his father, as a tribute for special military services, an extensive grant of land, called from him Osweiling, in which the present town of Oswestry is situated. The coincidence is extraordinary that two distinguished chieftains should have flourished-although upwards of two centuries had rolled between their reigns-bearing names so similar to each other, that from either, it may be presumed, the town could, not inappropriately, have derived its present designation. The evidence in favour of Oswald's right to the sponsorship of Oswestry is, however, in our opinion, so strong, that we must accord the honour to the Northumbrian Monarch, until the Cambrian or British claim shall be more authoritatively established. In the battle between Oswald and Penda, history informs us that the former was defeated and fell; that the barbarian victor ordered that the body of the slain monarch should be cut in pieces, and "stuck on stakes dispersed over 


\section{DERIVATION OF NAME.}

the field as so many trophies; or, according to the ancient verses that relate the legend, his head and hands only were thus exposed :-

' Three crosses, raised at $\boldsymbol{P}$ enda's dire command, Bore Oswald's royal head and mangled hands.' "'

After this battle the Welsh, or Cymry, (who seemed to have possessed for some time the district including Oswestry,) had called it Croes-Oswallt (Oswald's Cross), in allusion to Penda's ignominious exposure of Oswald's slaughtered body. The spot where the battle was fought is said to have borne the name of Maeshir (the long field), as marking the length and obstinacy of the conflict. In the fulness of the Saxon period the town was known as Oswald's Tree, in evident reference to Oswald's death, and subsequently, to the present day, "without let or impediment," by the name of Oswestry.

Industrious and talented antiquarian writers have given to the town other names and derivations. For instance, we are told that it was termed by the Saxons Blanc-Minster, White-Minster, Album-Monasterium, from its " fair and white Monastery," whilst the Cymry, or "Old Britons," as Williams denominates them, "called the town Tre'r Fesen, Tre'r Cadeiriau, the Town of the Oak Chairs," or, as another writer has it, "the Town of Great Oaks." These terms bear special allusion to Oswald's unfortunate arrival in this district; for the ancient seal of the town, cut in hrass, represents King Oswald sitting in his robes on a chair, holding a sword in his right hand, and an oak branch in his left, with the words around, "De Oswaldestre sigillum commune." In repeating the long and tedious catalogue of names and derivations, it will be proper to mention that one writer renders the designation Tre'r Cadeiriau as follows:- "Oswestry was called by the Britons Tre'r Cadeiriau, literally the Town of Chairs, or Seats, commanding an extensive view, (as Cadair Idris, the chair of Idris, and others,) as there are several eminences commanding such views in the neighbourhood." 


\title{
REVIEW OF ANCIENT HISTORY.
}

Here is a chapter on civic nomenclature and varied derivation, very curious, perhaps, to many readers, but little edifying to those who ask with the poet, "What's in a name?" And yet, ancient civic names, like many other ancient relics, have valuable and salutary uses. They are as finger-posts to the Past; in some instances inviting us to the honest path of truth and honour; in others deterring us from the rugged ways of ignorance and error. In almost all respects they enable us to institute comparisons and form contrasts between men and manners in ancient and modern days. Whilst looking at such names, we are too frequently reminded of times when Might overcame Right, and are gently led with thankful spirits to the Present, when, in our own happy and highly-privileged age, every Briton can sit "under his vine and under his fig-tree," none daring to make him afraid.

\section{REVIEW OF ANCIENT HISTORY.}

\section{The 1 britisyly 狂rion.}

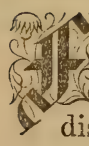

Or ages the site of the town, with the surrounding district, was the theatre of brutal contention, rapine, and aggrandisement. Here, as in the Border-Lands of Scotland, it was

\author{
"The good old rule, \\ * * * the simple plan, \\ That they should take who have the power, \\ And they should keep who can."
}

Education had not spread her benign wings over the people, to hush them into peace; and too commonly they who possessed the strongest physical power and the wildest barbarism became, in turns, "Lords of the Ascendant." There is no record extant that the Roman invaders of Britain pitched their tents within the Oswestrian district; and yet it is more than probable that part of the legion, which traver- 
sed from the south of our island, actually touched at Llanymynech Hill (a Roman settlement beyond doubt), and most likely constituted a portion of the army which, under Suetonius, found its way along the mountain-passes of North Wales into Anglesey, may have halted there, if the ground was pre-occupied by the invaded Britons, or the ancient encampment, Hen Dinas, had then stood. We can produce nothing more than conjectural evidence of such a visit. There is no Roman architecture in the town, to mark the presence of the invaders, nor are there Roman relics rich as those discovered at Llanymynech. If the Britons occupied Hen Dinas during the Roman visit to the district, the destruction of that encampment may have been accomplished by the Roman marauders; and yet it is believed by some that the Britons possessed Oswestry, intact, from before the death of Oswald to the invasion of Offa. A Roman invasion of Oswestry, and the real history of Hen Dinas (or Old Oswestry, as it is termed,) are therefore alike still involved in mystery.

On this "vexed question" we may add the following :"Remarking to a gentleman," says Mr. Hutton, "that I had gleaned some anecdotes relative to Oswald, he asked me if I had seen Old Oswestry, where, he assured me, the town had formerly stood. I smiled, and answered him in the negative. He then told me, " that the town had travelled three quarters of a mile to the place where it had taken up its present abode.' This belief, I found had been adopted by others with whom I conversed."

The earliest sovereign possession of Oswestry, noted in the Welsh historic page, was in the beginning of the fifth century, as already referred to. Oswal, son of Cunedda Wledig, is there represented to have been its first monarch. The Welsh Chroniclers, however, furnish no details of his reign; and no event connected with the town is subsequently recorded, till the memorable one of King Oswald's attack upon the Mercian King Penda, August 5th, A. D. 642. Oswald and Oswy 


\section{OSWALD AND PENDA.}

were sons of Adelfrid, the seventh King of Northumberland. These young Princes had been driven out of the kingdom of their father by Cadwallawn, who had before been expelled from Wales, his rightful possession, by Edwin. Oswald, after seventeen years' exile in Scotland, was restored to his kingdom by the overthrow and death of Cadwallawn. During his exile Oswald is said to have been baptized in a Christian church. He brought with him from Scotland a Christian bishop, Aidan, who preached Christianity to the people, and Oswald assisted him in his ministrations. The young ?iorthumbrian King appears to have been zealous in the Christian cause, both in the pulpit and the field. Penda was a pagan prince, and had united with Cadwallawn in laying Northumbria waste. Oswald's Christianity was not strong enough, it would seem, to subdue his revenge against Penda. The two monarchs at length met, a bloody conflict ensued, and Oswald was slain. The site of the closing scene of this memorable battle is said to have been a field called Cae Nef (Heaven's Field), "situated on the left of the turnpike road leading to the Free School." The writer from whom we quote mentions, that "Oswald approached with his army to what is called Maes-y-llan, or Church Field, then open." "About four hundred yards west of the church," he adds, "is a rising ground, where the battle began. The assailant appears to have driven Penda's forces to a field nearer the town, called Cae Nef. Here Oswald fell." These minute particulars give increased interest to the combat; but the writer does not state any authority for the details. We suppose it must have been merely traditionary. At the present time the sites of Cae Nef, and Church or Chapel Field, are well known to most of the inhabitants of the town. Oswald's remains were first interred in the monastery of Bradney, in Lincolnshire, and afterwards, in 909, removed to St. Oswald's, in Gloucestershire. The memory of the deceased King seems to have been held in great veneration, for churches, in various parts of the kingdom, still bear his name, as patron saint. 


\section{DEATH OF OSWALD.}

Speed, in his "History of Great Britaine," with his accustomed quaintness and minute graphic description, sums up Oswald's closing scene in the following language :- "But as the sunne hath his shadow, and the highest tide her ebbe, so Oswald, how holy soeuer, or gouernment how good, had emulators that sought his life, and his Countries ruine: for wicked Penda the Pagan Mercian, enuying the greatnesse that King Oswald bare, raised warres against him, and at a place then called Maserfeild, in Shrop-shire, in a bloudie and sore fought battle slew him; and not therewith satisfied, in barbarous and brutish immanitie, did teare him in peeces, the first day of August, and yeere of Christ Iesus six hundred forty two, being the ninth of his raigne, and the thirty eighth of his age : whereupon the said place of his death is called to this day Oswaldstree, a faire Market Towne in the same Countie. The dismembred limmes of his body were first buried in the Monastery of Bradney, in Lincolnshire, shrined with his standard of Gold and Purple erected ouer his Tombe, at the industry and cost of his neece Offryd, Queene of Mercia, wife vnto king Ethelred, and daughter to Oswyn that succeeded him. From hence his bones were afterwards remooued to Glocester, and there in the north side of the vpper end of the Quire in the Cathedrall Church, continueth a faire Monument of him, with a Chapell set betwixt two pillers in the same Church."

From the death of Oswald to 777, Oswestry is reported, as already mentioned, to have been in undisputed possession of the Britons. What its faithful history was during that long period we are unable to state. If the Britons did really occupy it, no event worthy of record seems to have occurred. If the Britons were preserved in peace, no chronicle is handed down to us of their social or industrial habits within the halycon time. Whether they improved their land, instructed their minds in arts useful to their tribe, or were sunk in ignorance, sloth, and selfishness, there is no voice or pen to 
inform us. Three centuries later than this period the domestic architecture of the Cymry was in the lowest state of rudeness. One of the regal mansions of Hywel Dda, their great law-giver, was made of peeled rods; the people lived in wattled huts; and a gentleman's hall was valued according to the number of posts it contained. These were filled up with wattled twigs and clay. The only notice we have of the period is in the Welsh Chronicles, and from them we learn that Cadwaladr (son of the Cadwallawn who was defeated and slain in a battle with King Oswald, near Denisbourne, in Northumberland,) the last of the Welsh Princes who assumed the title of Chief Sovereign of Britain, reigned over the Britons from A. D. 634 to 703 , and was succeeded by Idwal Iwrch, or the Roe. In one of the Welsh Triads, Cadwaladr is called "one of the three canonized kings of Britain," for the protection which he gave to the primitive Christians when dispossessed by the pagan Saxons; and his long reign is mentioned as having been peaceable, mainly in consequence, we are told, of his mother being sister to Penda, the Mercian king. Rhodri Molwynog, a brave and warlike prince, and grandson of Cadwaladr, succeeded to the western part of Britain about the year 720 , and was engaged in constant hostilities with the Saxons until near the close of his life, in 755. These dottings from Welsh history show that the Britons had not peace within their borders during the long period already mentioned, and that "battles and murders" were still the constant theme and employment of the Britons and Saxons. It is hardly probable that the Britons possessed this district peaceably, and not unlikely that they still had to fight for their lives and property, inch by inch, and foot to foot. War, even in the present day, is the curse of nations ; it fosters animosities, engenders ignorance and vice, and brutalizes man. What, then, must have been the effect of constant wars and incursions upon the British people by their invaders? The Britons had among them, about this period, their great bard, Llywarch Hen, a man ranked among 


\section{THE SAXON PERIOD.}

the wise bards of the Court of Arthur, and whose poetical effusions display profound talent, if not genius, for so rude an age; but we have no proofs that they profited much by his vigorous instructions, although his life was lengthened out to one hundred and fifty years. 'The art of printing was unknown in Llywarch's days, otherwise his humanizing productions might have wrought peace and harmony amongst both the oppressors and the oppressed.

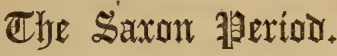

The period had now arrived when the sovereignty of the Britons was so powerfully disputed that they were compelled to yield to the cohort strength of the impetuous Offa, King of the Mercians. Mercia was the largest of the Anglo-Saxon kingdoms, and London was its capital. Offa passed the Severn with a mighty force, drove the Britons from their fertile and lovely plains, and limited the princedom of Powys to the western side of the celebrated ditch still known by the name of Offa's Dyke. 'Offa enjoyed a victorious reign, from the year 755 to 794 . During that period the finest part of Powys became a confirmed part of the Mercian territory, and Shropshire was permanently annexed to England. Owen and Blakeway, in their invaluable "History of Shrewsbury," remark, "Though there can be no doubt that the cession of Shropshire was obtained from the British Prince (Eliseg, it is supposed,) only by the military preponderance of the Saxon, yet it seems equally certain that it must finally have been the subject of a pacific negociation. A work of so much labour as Offa's Dyke, evidently designed, according to his practice in other places, as the line of demarkation between two kingdoms, could never have been carried into execution without the concurrence of the sovereign on each side of that boundary. * * * * The prince, thus despoiled of the fairest portion of his dominions, retired to Mathrafal, on the Vyrnwy, five miles beyond Welshpool, while Pengwern, 


\section{OFFA'S DYKE.}

degraded from the dignity of a metropolis, passed under the yoke of an English conqueror, and henceforth to be known by the name of Shrewsbury, a name of Saxon origin."

Offa's Drke, called by the Britons Clawdd Offa, extended nearly a hundred miles along the mountain border of Wales, from the Clwydian hills to the mouth of the Wye. Part of the Dyke may be traced at Brachy Hill, and Leintwardine, in Herefordshire, continuing northward from Knighton, in Radnorshire, over part of Shropshire, entering Montgomeryshire between Bishop's Castle and Newtown. It again appears in Shropshire, near Llanymynech, crosses Cern-y-bwch (the Oswestry race-course), descends to the Ceiriog, near Chirk, where it again enters Wales, and terminates in the parish of Mold, beyond which no traces of it are discovered. Offa may have imagined that the Clwydian hills, and the deep valley that lies at their base, would serve as a continuance of the prohibitory line. Pennant tells us, that in all parts the Dyke was constructed on the Welsh side, and that there are numbers of small artificial mounts, the sites of small forts along its course. In the MS. "Historia Wallica," we are informed, that the work of forming this Dyke, forty feet in height, occupied a numerous band of men, "6 able and accustomed to work in the fields," more than seven years. This great line of demarcation answered but little purpose as a line of defence, or even of boundary. The Border Lands were still the scenes of sanguinary contests, and superior force alone repelled the Britons. Severe laws were enacted against any that should transgress the limits prescribed by Offa; and one of these enactments declared, that "the Welshman who was found in arms on the Saxon side of the Dyke was to lose his right hand." These laws, however, were unheeded by the Britons. They deeply felt their injuries, and concerted means of revenge, and, as they hoped, emancipation. They formed an alliance with the kings of Sussex and Northumberland, broke through the boundary, 
attacked Offa's camp, slew great numbers, and the Mercian king himself narrowly escaped with a small remnant of his army. On this disaster Offa retired into his own dominions, meditating vengeance. Hostages having been given to him by the Britons, a short time before, during a brief period of peace, he now dealt out to them severe treatment, strictly confining them, and selling, or reserving for perpetual slavery, their wives and children. Still breathing destruction he marched into the confines of Wales with a powerful army, but for years was gallantly repelled by the Britons. At length the contending forces met on Rhuddlan Marsh (now the scene of peaceful arts, the Chester and Holyhead Railway passing over it), and the Britons, under the command of Caradog, were entirely defeated with terrific slaughter, their leader being slain in the conflict. 'The fury of the Saxon prince did not cease with victory. He savagely massacred the men, women, and children who fell into his hands; and, according to tradition, the remaining Britons, who had escaped the enemy's sword, fleeing with haste over the marsh, perished in the waters by the flowing of the tide. This tragedy has been carried down to posterity by a plaintive Welsh melody, called Morva Rhuddlan, the notes of which are amongst the most touching and deeply-pathetic of Cambrian minstrelsy.

Having traced Offa's Dyke, it is necessary to describe the course of WAтT's DyкE, as the space between these two great lines of demarcation was deemed neutral ground both by the Britons and their invaders, and subsequently, during the Norman period, became part of what is denominated the Marches, although it is difficult to define correctly the precise extent of territory they occupied. Watt's Dyke is supposed by various writers to have been constructed anterior to the time of Offa. Its course is marked by Pennant as follows :"It appears at Maesbury, in the parish of Oswestry, and terminates at the river Dee, below Basingwerk Abbey. The southern end of the line is lost in morassy grounds; but was 


\section{WATT'S DYKE.}

probably continued to the river Severn. It extends its course from Maesbury to the Mile Oak [on the old road from Oswestry to Shrewsbury]; from thence through a field [now belonging to Edward Williams, Esq., Solicitor, of Oswestry], called Maes-y-garreg-llwyd, between two remarkable pillars of unhewn stone [strongly resembling Druidic altar stones]; passes by the town [below the Shelf-bank Field], and from thence to Old Oswestry, and by Pentreclawdd to Gobowen, the site of a small fort called Bryn-y-Castell, in the parish of Whittington; runs by Prys Henlle and Belmont; crosses the Ceiriog, between Brynkinallt and Pont-y-blew Forge, and the Dee, below Nant-y-Bela; from whence it passes through Wynnstay Park, by another Pentreclawdd, to Erddig, where there was a strong fort on its course; from Erddig it runs above Wrexham, near Melin Puleston, by Dolydd, Maesgwyn, Rhos-ddû, Croes-oneiras, \&c.; goes over the Alûn, and through the township of Llai, to Rhydin, in the county of Flint, above which is Caer-estyn, a British post; from hence it runs by Hope church along the side of Molesdale, which it quits towards the latter place, and turns to Mynydd Sychdyn, Monachlog, near Northop, by Northop Mills, Bryn-Moel, Coed-y-Llys, Nant-y-Flint, Cefn-y-Coed, through the Strand Fields, near Holywell, to its termination below the Abbey of Basingwerk." The Chester and Shrewsbury Railway intersects these two ancient dykes. At the junction of the branch line to Brymbo, Minera, \&c., the railway crosses Watt's Dyke, and continues to run on the left side of it, travelling from Chester, for about fourteen miles, until Gobowen is reached, where the line again crosses the dyke; the superintendants of modern improvements, especially railway engineers and contractors, paying little if any deference to mere antiquities. By this route the railway traveller passes a considerable distance on the neutral ground, where alone, for many years, the trade and commerce of the Britons, the Saxons, and the Danes, were transacted. Offa's Dyke at Brymbo is about two miles to the right, from Chester, and 


\section{WATT'S DYKE.}

runs parallel with the railway for about eighteen miles. Churchyard, in his "Worthies of Wales," thus chronicles, in his quaint verse, the use to which the "free ground" was applied in early days:-

"Within two miles, there is a famous thing

Called OFFA's DyKe, that reacheth farre in lengthe;

All kind of ware the Danes might thither bring;

It was free ground, and called the Britaines' strength.

W AтT's DYкE, likewise, about the same was set,

Between which two, both Danes and Britaines met."

For many years after Offa's memorable defeat of the Britons on Rhuddlan Marsh, the history of the district conveys but little information interesting in the present day. "Wars, and rumours of wars," are the only topics on which past historians have filled their pages in reference to this period. Rhodri Mawr (Rhoderick the Great), one of the most celebrated warriors and princes of Wales, succeeded to the sovereignty of North Wales and Powys in 843 . In the year of his succession his territories were invaded by Berthred, King of Mercia, whom he defeated with great loss. Rhodri left three sons, and, according to the law of gavel-kind, he divided his dominions among his children. His son Mervyn had the principality of Powys, with the palace of Mathraval. His three sons were called $y$ tri thywsog taleithiog, or diademed princes, from their wearing diadems of gold set with precious stones; and Anarawd, his eldest son, received a yearly tribute from the Prince of Powys. Contentions still continued, and intestine divisions kept the Britons in as violent commotion as if they were battling with their avowed enemies on the border. Mervyn did not long enjoy his dominion, as he was slain in 892 by his own subjects, headed by his brother Cadell, who took possession of the throne. The reign of Cadell was also brief, and his son Hywel Dda (Howel the Good) succeeded him. The Welsh Justinian, as Hywel has been called, died in 984, deservedly honoured by his subjects, and leaving four sons, all of whom perished in the desolating wars to which his country soon after fell a prey. 


\section{POWYS VADOG.}

\section{The A̛orman łyeriờ.}

Saxon dominance was now rapidly approaching to its close; and the Britons were about to be exposed to the incursions of a new body of invaders, under the usurpation of William, surnamed the Conqueror. Bleddyn ab Cynvyn, with his brother, obtained in 1062 the sovereignty of North Wales and Powys, through the influence of the Saxon King Edward. Bitter hostilities subsequently occurred between Bleddyn and his kindred; at length the succession to the whole principality passed from his children, but Powys-land devolved to his sons, and came at length entire to Meredydd, the eldest born, after the contentions and slaughter incident in those days to such partitions. Oswestry, we are told, was called Trefred (a contraction of Tre Meredydr, Meredydd's Town), in honour of this prince, but after his death the name was soon discontinued, and the town resumed its former appellation of Oswald's-tree, or Oswestry. His eldest son, Madog, inherited from his father the tract known by the name of Powys Vadog, which consisted, according to the division of the times, of five cantrevs, or hundred townships; and these were subdivided into fifteen commots, or cwmwds : 


\section{FITZ-ALAN.}

To Madog is assigned the honour of erecting the Castle of Oswestry. Whether he is entitled to this distinction it would be difficult now to prove. Welsh historians assert, that he built also the Castles of Overton (Flintshire) and Caereinion, and that in the former, which received the additional name of Madog, he resided. Powell says of him, that he was "ever the King of England's friend, and was one that feared God, and relieved the poor." Madog married Susanna, daughter of Grufydd ab Cynan, Prince of North Wales, by whom he had two sons, Grufydd Maelor and Owain ab Madog. To the first he gave the two Maelors, Yale, Hopedale, Nanheudwy, Mochnant-is-Rhaiadr, \&c.: to Owain, the land of Mechain-is-Coed; and to his natural son, Owain Brogyntyn, a nobleman of distinguished talents, he granted the lordships of Edeirnion and Dinmael. The last-named Owain resided at Brogyntyn, near Oswestry, now called Porkington, whence he assumed his surname. His dagger and cup are still preserved at Rûg: and many families in Merionethshire and Denbighshire are directly descended from him. Madog's second wife was Maud Verdon, an Englishwoman of noble lineage. He died in $\mathbf{1 1 5 9}$ at Winchester, whence his body was conveyed to Meivod, in Montgomeryshire, where it was deposited in the Church of St. Mary, which he himself had built some years before. His widow is stated to have been married to William Fitz-Alan, Lord of Clun, and he, in right of his wife, obtained the town and castle of Oswestry. FitzAlan was a descendant of Alan, one of the companions of the Conqueror, and was the first of his name who bore the title of "Baron of Oswaldestre." Alan was progenitor of the entire noble family which from him derived the name of Fitz-Alan, and for many succeeding centuries were the most distinguished personages in Shropshire. From this powerful race is descended the present Duke of Norfolk, who holds the title of "Baron of Oswaldestre," in addition to his other patrician honours. His Grace's ancestor, Thomas, Duke of Norfolk, married Lady Mary, daughter of Henry, 
the last Earl of Arundel named Fitz-Alan, 13th Elizabeth, when the barony of "Oswaldestre" was conveyed to the Duke.

The Norman conquest was "a heavy blow and great discouragement" to the impetuous Britons. During that eventful period almost the whole of Shropshire was parcelled out, and bestowed by William the Conqueror on his kinsman, Roger de Montgomery, as a reward for his great military services in the conquest. The Earl of Shrewsbury, whilst thus taking possession of Powys, among his other newlyacquired lands, brought under his subjection the town and castle of Trefaldwyn, (from Baldwin, Montgomery's lieutenant,) which fortress he strongly fortified, and afterwards called it after his own family name. Hugh Lupus, Earl of Chester, (the founder of the Grosvenor family,) likewise did homage for Englefield and Rhûvoniog, with the country extending along the sea shore from Chester to the waters of Conway. Ralph Mortimer did the same for the territory of Elvel; as did Hugh de Lacie for the lands of Eulas ; and Eustace Cruer for Mold and Hopedale. Brady relates out of Domesday, that William the Conqueror granted to Hugh Lupus North Wales in farm, at the rent of $£ 40$ per annum, besides Rhos and Rhûvoniog. These Norman Barons erected fortresses on their lands, and, so far as they were able, settled in them English and Norman defenders. In a MS., relating to the Welsh Marches, from the library of the late Philip Lloyd Fletcher, Esq., of Gwernhaylod, in Flintshire, it is stated " that about this time, Bristol, Gloucester, Worcester, Shrewsbury, and Chester were rebuilt and fortified, and formed a line of military posts upon the frontiers. Thus the last asylum of the Welsh was invested on almost every side, or broken into by their enemies. The kingdom of North Wales, reduced to the island of Anglesey, to Merioneth and Caernarvonshire, and to part of the present counties of Denbigh and Cardigan, still preserved the national character and 
importance. The natives of Wales, aided by the virtue and courage of their Princes, became more formidable than ever to the English; and at times, as they acquired union with additional vigour from despair, their invaders, instead of being able to make new conquests, held those which they had already obtained by a precarious tenure. William's policy, in giving to his barons the power to make such conquests in Wales as they were able, led to the erection of the Marches Lordships, of which Oswestry formed a part. These lordships consisted of more than a hundred petty sovereignties, and were the fruitful source of innumerable disorders, till their partial suppression in the reign of Henry VIII. Pennant says, that William's design was, in establishing these seignories and jurisdictions, to give to those whom he had brought over to. England the power of providing for themselves, and to reduce, at the same time, the opposition of the Welsh people. The precise extent of the Marches Lordships it is difficult, as we have already said, to define. During the Saxon period the Severn was considered the ancient boundary between England and Wales. The lands conquered by Offa on the western side of that river were annexed to Mercia, and afterwards incorporated with the monarchy by Alfred the Great. The term Marches signifies generally the limits or space between England and Wales, of which the western part of Shropshire, Oswestry included, formed a principal portion. Of the Norman Barons, besides the first Earl of Shrewsbury, who did homage for royal grants of territory, were Fitzalan for Oswestry and Clun; Fitz-Gwarine for Whittington; and Roger le Strange for Ellesmere. The tenure by which the Baronies Marches were held was, that "in case of war the lords should send to the army a certain number of their vassals ; that they should garrison their respective castles, and keep the Welsh in subjection. In return for these services the lords had an arbitrary and despotic power in their own domains. They had the power of life and death, in their respective courts, in all cases except those of high treason. 
In every frontier manor a gallows was erected; if any Welshman passed the boundary line fixed between the two countries, he was immediately seized and hanged. Every town within the Marches had a horseman armed with a spear, who was maintained for the express purpose of taking these offenders. If any Englishman was caught on the Welsh side of the line, he suffered a similar fate. The Welsh considered everything that they could steal from their English neighbours as lawful prize." After the conquest of Wales by Edward I. the Baronies Marches were continued, but under regulations somewhat different from the former. In the reign of Edward IV. they were governed by a Lord President and Council, consisting of the Chief Justice of Chester, and three Justices of Wales. In cases of emergency other parties were called in. By a statute passed in the reign of Henry VIII. the principality and dominion of Wales became formally annexed to England; and all the Welsh laws, and most of their peculiar customs and tenures, were by this statute entirely abolished. By this statute also four new counties were formed, Brecknockshire, Denbighshire, Montgomeryshire, and Radnorshire. The Marches became annexed partly to England, and partly to the new counties of Wales. The President and Council of the Marches were however allowed to continue as before, and their general court was held at Ludlow. A statute was passed in the reign of William III., by which the government of the entire principality was divided between two peers of the realm, on whom was conferred the title of Lords Lieutenant of North and South Wales. From that period the Lordship Marches were entirely abolished.

There is another salient point in the history of Wales which it will not be inappropriate here to mention. Many of our readers have heard or read of the Royal Tribes of Wales. "The five regal Tribes, and the respective representative of each, were considered as of royal blood. The fifteen common Tribes, all of North Wales, and the respective 


\section{THE ROYAL TRIBES.}

representative of each, formed the nobility, were lords of distinct districts, and bore some hereditary office in the palace. Grufydd ab Cynan, Prince of North Wales, Rhys ab Tewdwr, of South Wales, and Bleddyn ab Cynvyn, of Powys, regulalated both these classes, but did not create them; as many of the persons, placed at their head, lived before their times, and some after. Their precedence, as it stands, is very uncertain, and not governed by dates; the last of them were created by Davydd ab Owain Gwynedd, who began his reign in 1169 . We are left ignorant of the form by which they were called to this rank. Mr. Vaughan, of Hengwrt, informs us that ' Grufydd ab Cynan, Rhys ab Tewdwr, and Bleddyn ab Cynvyn made diligent search after the arms, ensigns, and pedigrees of their ancestors, the nobility and kings of the Britons. What they discovered by their pains in any paper or records, was afterwards by the Bards digested, and put into books, and they ordained five Royal Tribes, there being only three before, from whom their posterity to this day can derive themselves, and also fifteen special Tribes, of whom the gentry of North Wales are for the most part descended!" "

It will be seen from the foregoing pages that we have abstained from all minute detail in our description of the continued struggles for mastery between the Welsh and their own kindred, as well as of the strife for power and dominion between the Cambrian princes and their foreign invaders. These scenes in the history of Wales are nothing more, to use the eloquent language of Warrington, than " a recital of reciprocal inroads and injuries-a series of objects unvaried and of little importance, which pass the eye in a succession of cold delineations, like the evanescent figures produced by the camera obscura. The characters and events are not brought distinctly into view, nor are they sufficiently explained, to enable the historian to judge of their proportions, their beauty, or defects; whence he can neither develope the principles of action, nor trace the connection of causes with effects, by 


\section{WILLIAM FITZ-ALAN.}

leading incidents, or by the general springs which govern human affairs." "The story of our country under its native princes," observes another impartial writer on Welsh history, " is a wretched calendar of crimes, of usurpations, and family assassinations; and in this dismal detail we should believe ourselves rather on the Bosphorus than the banks of the Dee." The British or Welsh rulers had doubtless much to complain of against their Roman, Saxon, and Norman invaders; but their own conduct towards their own people - to those who by affinity claimed their protection and regard-was quite as guilty as that of their foreign foes.

Throughout the entire reign of Henry I. we read in the Welsh annals of nothing but "a series of retaliated injuries arising in regular succession; evils naturally springing from the passions, where they usurp the sword of justice." Henry died about the year 1135, and Stephen succeeded to the English throne, and was soon embarked in a sea of troubles. Engaged in continual hostilities, and in supporting a doubtful title, he prudentiy concluded a peace with the Welsh, and allowed them to retain the territories they had lately recovered, free of homage or tribute. The incidents of Stephen's reign were marked by no feature of national interest'; and the only reference made to it in connection with this district is William Fitz-Alan's espousal of the claim made by the Empress Maud to the English crown. His union with other noblemen, to dethrone Stephen, exposed him to danger, and he was compelled to leave the kingdom, abandoning his lands and other property to the incensed monarch. Whilst an exile from England he remained faithful to the interests of the Empress ; and on his return to this country on the death of Stephen, and the accession to the throne of Henry II., he reaper the reward of his spirit and fidelity, by receiving back all his forfeited honours and estates, including the Castles of Oswestry and Clun. Of Oswestry Castle we shall speak particularly in subsequent pages. Of Clun we may at 20 


\section{THE INVASION OF WALES.}

present say, that it remained in the direct line of William Fitz-Alan down to the reign of Queen Elizabeth, when the last Earl died. By the marriage of Mary Fitz-Alan with Philip Howard, the son of Thomas, Duke of Norfolk, it became vested in that noble family. From them it passed to the Walcotts, and afterwards, by purchase, to Lord Clive, in whose family it continues. The Duke of Norfolk still retains the title of "Baron of Clun," as well as that of "Baron of Oswaldestre."

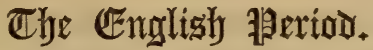

Henry was an inveterate and formidable enemy to the interests of Wales. He speedily employed his utmost force in attempting to subjugate the Cambrian people; and it is recorded of Madog ab Meredydd, Prince of Powys, who had united with the enemies of his country, that he incited the English king to an invasion of North Wales. Henry listened to the solicitations of the Powysian prince, and eagerly exerted every means for the conquest of the country. He quickly raised a powerful army, and marched without delay into North Wales. Mathew Paris states that the levy of Henry, raised at this time, amounted to 30,000 men. Owain Gwynedd, in this campaign, gallantly led the Welsh, and in one of the actions, at Coed Euloe, near Hawarden, Flintshire, the monarch himself, who had encamped near the field of battle, escaped from the hands of the Welsh with the greatest difficulty. The English forces, having been strengthened, pursued the Welsh, and at length Prince Owain, fearful that his army would perish for want of provisions, concluded a peace with the King of England. He himself and his chieftains submitted to do homage to Henry, and to yield up the castles and districts in North Wales which, in the last reign, had been obtained from the English. Lord Lyttleton tells us, that to complete this humiliating position, Owain was obliged to deliver up two of his sons as pledges of his future obedience. The year after this important event a general 
peace took place between England and Wales; the princes and all the chieftains of South Wales repaired to the court of England, where Henry granted peace, on the Welsh doing homage for their own territories, and formally ceding to him the districts recovered from the English in the last reign. This peaceful state of things was but of short duration. Rhys, the son of Grufydd ab Rhys, immediate heir to the sovereign power of South Wales, having been outraged by several English lords, threw off his allegiance, commenced a revolt, and rallied around him a numerous force, which perplexed and baffled the English monarch. Shortly afterwards, fired by the gallant example of Rhys, the Prince of North Wales (Owain Gwynedd), and all his sons, his brother Cadwaladr, and the chieftains of Powys, united with him, in the endeavour to regain their independence and honour. After some slight skirmishes with the Welsh, Henry gathered together a formidable force, with which he marched into Powys, breathing slaughter and extermination against the inhabitants. All the historical writers, in describing this fearful onslaught, admit that few events of ancient times were more deeply stained with the blood of innocence. The English army, formed of the choicest troops, from Normandy, Anjou, Flanders, Brittany, and other territories which Henry possessed in France, entered the Welsh confines at Oswestry, where it was encamped for some time. The forces of North Wales were collected under the command of Owain Gwynedd and his brother Cadwaladr; the army of South Wales was headed by the chivalrous Rhys ab Grufydd; and the men of Powys were led by Owain Cyveiliog, and the sons of Madog ab Meredydd. The combined forces of the Welsh assembled at Corwen, where they awaited the approach of the English. Henry, burning with ardour to attack the enemy, marched his army to the banks of the Ceiriog, near the present village of Chirk, and at once ordered that the woods on each side of the river be cut down, to prevent ambuscades and sudden approaches of the enemy. It is related by some writers, that 
on the passage of the Ceiriog Henry was in imminent danger of losing his life: attempting to force a bridge, an arrow aimed at him by the hand of a Welshman must inevitably have pierced his body, if Hubert de St. Clare, Constable of Colchester, perceiving the danger, had not in a moment sprung before his sovereign and received it into his own bosom, and thereby met with his death-wound. Whilst the English soldiers were employed in felling the woods, a detachment of the Welsh forces forded the river, and suddenly attacked the van of Henry's army, composed of pikemen, considered to be the most daring and gallant portion of his soldiers. A fierce battle ensued; many were killed on both sides, but at length Henry gained the passage, and advanced onward to the Berwyn mountains, to recruit his troops. 'There he remained in camp for several days. The Welsh were posted on the mountain-heights opposite, watching with lynx-eyed care every movement of the enemy. They succeeded in cutting off his supplies, and his army was reduced to extreme distress and privation, for want of food for man and horse. To increase his difficulties, sudden and heavy rains fell, which rendered the country on the Berwyn side so slippery and dangerous, that neither men nor horses could stand on their feet. Torrents of water, from the incessant rains, poured down from the mountains into the vale where Henry was encamped; and, unable to maintain his ground amidst all these unexpected disasters, he retired, with great loss of men, and, what was more annoying to his vaunting spirit, with defeat and disgrace. Fired with revenge, and urged by the barbarism which ever marks the tyrant, he commanded that the eyes of all the hostages which had been placed in his hands should be put out. The two sons of Rhys ab Grufydd, Prince of South Wales, and the two sons also of Owain Gwynedd, Prince of North Wales, became the unfortunate victims of Henry's cruelty. Holinshead, in his Chronicles, tells us, that besides these young chieftains, the atrocious monarch caused the sons and daughters of several Welsh lords to be treated with the same severity; ordering 23 


\section{SIARTER CWTTA.}

the eyes of the young striplings to be pecked out of their heads, and the ears of the gentlewomen to be stuffed.

In the annals of Wales this battle is ranked among the brightest achievements of the Welsh, in their long-continued struggles for liberty. The site is known by the mournful designation of Adwy'r Beddau, or the Pass of the Graves. The conflict is called in most of the ancient books, "The Battle of Crogen." Yorke observes, "it has been erroneously said that the term Crogen was used in contempt and derision of the Welsh; but that was not the truth : the English meant to express by it animosity, and the desire of revenge." "Many of the English," he adds, "were slain, and buried in Offa's Dyke, below Chirk Castle, and the part so filled up is to be seen, and forms a passage over it, called to this day $A d w y^{\prime} r$ Beddau, or the Pass of the Graves." The late Mr. William Price, in an annotated edition of his "History of Oswestry," published in 1815, has the following note on the Battle of Crogen :- " Owain Gwynedd slept at Tyn-y-Rhos, the present residence of Richard Phillips, Esq., who has still in preservation the bedstead he at that time lay upon. Likewise a Deed or Lease of a piece of land, of five acres, for $2 \mathrm{~s}$. $8 \mathrm{~d}$. per year; with a cock and hen at Christmas, and a man a day in the harvest; which still preserves the name."

Turning for a moment to the civil government of Oswestry, it may be mentioned that in the reign of Henry II, the first Charter was granted to Oswestry, by William, Earl of Arundel. The Welsh called it "Siarter Cwtta," the Short Charter. It was a Charter of protection, of which there were many granted about this period. It states, "I have received in protection my Burgesses of Blanc-Minster. Richard de Chambre was Constable of White-Minster. Thomas de Rossall held Rossall, of John Fitz-Alan, in chief, of one knight's fee at White-Minster." Guto (y Glyn), an excellent poet who flourished from 1430 to 1460 , a native of 24 


\section{VISIT OF BALDWIN AND GIRALDUS.}

Llangollen, and domestic bard to the Abbot of Llanegwestl, or Valle Crucis, near that romantic town, speaks of WhiteMinster in his days. He says, "I know not of any Convent of Monks superior to White-Minster."

About the year 1188, William Fitz-Alan, Earl of Arundel, gave a sumptous banquet in the Castle of Oswestry, to Giraldus Cambrensis, and Baldwin, Archbishop of Canterbury, on their return from Wales, the bleak and barren mountains of which they had just travelled over, in an attempt to incite the people to the intended Crusade to the Holy Land. Giraldus seems to have considered that the entertainment given by the Norman Earl was too luxurious for saintly personages. He speaks, however, with much complacency of the comfortable accommodations provided for him and the Archbishop at Shrewsbury, whither they repaired from this town. " "From Oswestry," says he, " that Prelate and his retinue came after Easter (1188) to Slopesbury, where they remained some days to recruit and refresh themselves, and many assumed the cross in obedience to the precepts of the Archbishop, and the gracious sermon of the Archdeacon of St. David's. Here also they excommunicated Oen de Cevelioc (Owain Cyveiliog, Prince of Powys), because he alone of all the Welsh princes, had not advanced to meet the Archbishop." The visit of Giraldus and Baldwin to Oswestry might have been induced by a two-fold motive, namely, to partake of the princely hospitality of Fitz-Alan, in his baronial castle, and to hold "ghostly communication" with Regner, Bishop of St. Asaph, who at this period resided in Oswaldestre.

The succeeding portion of Henry II's long reign was largely occupied with plans and movements to subdue the Welsh princes and their people. After repeated struggles, the English monarch saw, with exulting spirit, that he had reduced Cambrian independence to a bye-word of contempt, by seducing them from patriotism and virtue, and rendering 


\section{BURNING OF THE CASTLE.}

them a disunited and improvident people. When he had accomplished this signal victory over them, and hoped to enjoy further years of sovereign power in comparative ease and tranquillity, the fate even of monarchs was dealt out to him. His mortal career was ended, and he was "gathered to his fathers :"-

"The glories of our blood and state are shadows, not substantial things ;

There is no armour against fate ; Death lays his icy hand on kings."

Henry was succeeded by Richard, his son, surnamed Cœur-deLion, whose reign continued for about ten years, when he was slain at the siege of Chalons, in France, and John, his brother, ascended the throne. During Richard's monarchy the town of Oswestry was not marked by any event worthy the record of the contemporary historian.

The reign of John was distinguished by strong enmity to the Welsh. In 1211 he assembled a large army at Oswestry, and was there joined by many of the Welsh Chieftains, his vassals, with whom he marched to Chester; resolving to exterminate the people of North Wales. It is revolting to trace the history of this feeble-minded and capricious king. His reckless attacks upon Wales, and his inveterate quarrel with his son-in-law, Prince Llywelyn ab Jorwerth, added to his troubles, and probably hastened his end. As a last effort against Wales, resenting Llywelyn's stern defence of Cambrian independence, John demolished the castles of Radnor and Hay; and then, proceeding to the Marches, he set fire to Oswestry Castle, then under the governorship of John Fitz-Alan, (who had united with the barons of England in renouncing allegiance to the English Monarch, on his refusal to confirm their constitutional rights,) and burnt it to the ground.

In the reign of Henry III. John Fitz-Alan, who was reconciled to the king, procured for his Manor of Blanc- 


\section{LLYWELYN AB JORWERTH.}

Minster the grant of a Fair on the eve, the day, and the day after St. Andrew's feast. The Bailiffs were also made clerks of the market, with privilege to imprison any person detected in forestalling; for which they were paid twenty marks as a consideration. These petty officers, "dressed in a little brief authority," abused their power, and gave occasion to frequent remonstrances from the inhabitants. Powel, who seems to have paid great deference to " the powers that be," concludes, not very logically, we think, that it was " no wonder that so many of the grievances which the Welsh so much complained of to Edward I. should originate from this place."

The historic facts recorded subsequent to this period are brief and meagre. We are told that in 1233 Oswestry was again destroyed by fire. Llywelyn ab Jorwerth had just made an inroad into the county of Brecknock, destroying all the towns and fortresses belonging to that territory; he then invested the castle, lay before it a month, raised the siege, finding his efforts to be fruitless, set fire to the town, and pursued his way to the Marches. Conflagration and ruin marked his progress: he burnt the town of Clun, in Salop, demolished Redde Castle, in Powys, and laid Oswestry in ashes. A few months afterwards, Llywelyn and Lord Pembroke, having joined their forces, made another inroad into the English Marches, and having rendered all that country a scene of devastation, they finished their fiery career by laying part of the town of Shrewsbury (Frankwell, it is supposed,) in ashes.

Early in the reign of Edward I. that monarch was intent on bowing the stubborn neck of Llywelyn ab Grufydd (the last native sovereign Prince of Wales). Llywelyn was refractory, and ambitious to maintain his order. Edward summoned him to a parliament in London, but Llywelyn refused to comply with the royal command. In reply, he offered (Oct. 14, 1276-7,) to repair to Montgomery, or to "the 


\section{THE TOWN WALLS.}

White Monastery of John Fitz-Alan," as Oswestry was then called, but declined a journey to the metropolis of England. On the receipt of this answer, by which Edward, resolute to exact a personal obedience, was, or affected to be, greatly enraged, the Parliament immediately condemned Llywelyn as a rebel, for his non-appearance. The melancholy end of the Welsh prince is well known. "If," says an elegant historian, "the valour of Llywelyn, his talents, and his patriotism, had been exhibited upon a more splendid theatre,-on the plains of Marathon, or in the straits of Thermopylœ,-his name would have been recorded in the classic page, and his memory revered, as an illustrious hero, and as a gallant assertor of the rights of nature."

Edward did not confine his attention to Wales only, but extended it to the Borders, and included in his eagle-eyed glance the town of Oswestry. " Provision was made," says Pennant, " against future insults ; for in the reign of Edward I. the town (Oswestry) was surrounded with walls. This happened when that politic monarch meditated the conquest of Wales; he therefore thought proper to secure this town, one of the keys of the country, with proper defence." He commenced the erection of the walls in 1277. They are said to have been about a mile in circumference, with an intrenchment on the outside, which could be filled with water from the numerous streams in the vicinity. Edward's order to put Oswestry into a state of defence issued from Shrewsburythe seat of his government for several months-and his letters patent, directed to the Bailiffs and Burgesses of the ancient town, are worthy of record, as they show the mode in which taxation was levied in early days. This curious document is as follows :-

"Of the Murage of Oswaldestre. The King to the Bailiffs and Burgesses, and the other good men of Oswaldestre greeting.

"Know ye that we have granted in aid of enclosing our 28 


\section{THE MURAGE.}

town of Oswaldestre, that from the feast of St. Thomas the Apostle in the twelvth year of our reign to the end of twenty years thence ensuing, ye may take in the same Town, to the reparation of the walls of the same Town, of every horse-load of corn to be sold, one halfpenny ; of every horse and mare, $o x$ and cow sold, one halfpenny ; of every hide of horse and mare, ox and cow, fresh, salt, or tanned, one farthing ; of every cart bringing salted flesh to sell, twopence; of five bacons sold, one halfpenny; of a salmon fresh sold, one halfpenny ; of ten sheep, goats, or pigs sold, one penny ; of ten fleeces of wool, one penny; of one hundred skins of sheep, goats, stags, hind bucks and does, one penny; of every hundred skins of lambs, kids, hares, rabbits, foxes, cats, and squirrels, one halfpenny; of every cart of salt to sell, one penny; of every horse-load of salt to sell by the week, one farthing; of every horse-load of cloth to sell, one penny ; of every entire cloth to sell in the town of Gloucester, one penny; of every cloth of silk brocaded and diapered with gold, one penny ; of every cloth of silk without gold and chef de cendall, one halfpenny; of every dole of wine to sell, two pence; of every horse-load of honey to sell, one penny ; of every dole of honey to sell, four pence ; of every sack of wool to sell, four pence; of every truss of cloth to sell brought by cart, four pence ; of every horse-load of cloth to sell, or other diverse and small things coming to be sold in the same town, one halfpenny ; of every cart of iron to sell, one penny ; of every horse-load of iron to sell, one halfpenny; of every carriage of lead to sell, two pence ; of tallow and lard to sell, one farthing; of every hundred of alum and copperas to sell, one halfpenny; of two thousand onions, a farthing; of every thousand of herrings to sell, one halfpenny; of every hundred of boards to sell, one halfpenny ; of every mill sold, one penny; of every thousand of laths sold, one penny ; of every new cart sold, one halfpenny ; of every hundred of faggots to sell, one halfpenny ; of every quarter of salt, one farthing ; of every twelve horse-loads of coal sold, one halfpenny; of 


\section{CHURCH GRANT.}

every thousand of all manner of nails to sell, except cart nails, one farthing; of a thousand of cart nails to sell, one halfpenny; of every hundred of horse shoes and clouts to carts to sell, one halfpenny; for every truss of any sort of merchandise coming for sale to the aforesaid town, of the value of two shillings, one farthing; of every cauldron sold to brew, one penny; of every quarter of oatmeal to sell, one halfpenny: And we therefore command that ye take the said custom to the end of the term aforesaid, but the term of the said twenty years being compleat, the said custom ceases and is done away. In witness, \&c."

Pennant states that the walls were begun in the sixth of Edward I., and that "the murage or toll was granted on the inhabitants of the county, which lasted for six years, in which time it may be supposed the walls were completed."

Archbishop Peckham visited Oswestry, June 12, 1284. He was received with great respect by Anian, Bishop of St. Asaph, the clergy, and others. Anian obtained from the king a confirmation of the rights and privileges of his church, and received from John Fitz-Alan, Earl of Arundel, and Baron of Oswestry and Clun, the grant to his church of one hundred acres of land at St. Martins, paying yearly at Midsummer, for ever, a pair of gilt spurs ; with the condition, that neither the bishop nor his successors should alienate the same. This grant is dated at Album Monasterium, 1271. Richard, son of the said John Fitz-Alan, afterwards confirmed it, and also gave forty-five acres more, with the manor-house belonging thereto. Anian had a long dispute at Rome respecting the placing of a vicar in Blanc-Monasterium, the tithes of which his predecessor had given to the Abbey of Shrewsbury. The issue was, that the abbot, for the peaceable enjoyment of his tithes, gave the whole of his lands at St. Martins, upon paying two Welsh knives yearly. These said knives, if now produced at Sheffield, would doubtless disturb the risible faculties of the keen knife-manufacturers there. 


\section{THE MORTIMERS.}

Edward II. was much annoyed and harassed in the latter part of his reign, partly from his want of fidelity to many of his most distinguished nobles, the two Mortimers, uncle and nephew, among their number. A revolution broke out against the king, in 1325, concocted, it is said, by the queen and her favourite, Roger Mortimer, Lord of Wigmore, in which the French monarch also took part. A strong feeling for and against Edward was manifested in Shrewsbury, where the Mortimers were well known. Edmund, Earl of Arundel, was one of the few peers who had preserved their loyalty to the crown. He assembled a multitude of his Welsh tenantry at Oswestry, with a view of seizing Shrewsbury for the king. Arundel was, however, apprehended near Shrewsbury, with certain of his adherents, after an obstinate struggle. The Earl was taken from that town to Hereford, where he expiated his loyalty on the scaffold. For this "service" the "good men of Salop" had all the goods and chattels found upon him. After his execution, the queen, to show her attachment to her paramour, Lord Mortimer, obtained the Castle of Oswestry for that favourite. In 1324, Edmund, Earl of Arundel, granted two shops in Leg-street, to the burgesses of Oswestry for ever, on payment of 13s. 4d. yearly. This grant is witnessed by "Lord Richard, Abbot of Haggemon," and others, and "dated at Oswaldestre, on the feast of St. Michael, in the 18th year of the reign of King Edward, the son of King Edward."

Edward III.'s reign was long and glorious. It was distinguished by the ever-memorable battle of Cressy. Part of the inhabitants of this town doubtless contributed to the victory thus obtained; for in 1346 the king directed Richard FitzAlan to raise two hundred of his vassals from Oswestry and Clun, to attend him in the French wars.

In 1397 Richard, Earl of Arundel and Surrey, was attainted and executed, when Richard II. seized all his lands and 31 


\section{THE GREAT PARLIAMENT.}

manors, and granted them to William le Scrope, Earl of Wiltshire. In the Historia Regum Angliae we find the following bit of superstition entertained at this period. On this occasion the Earl of Arundel must, of course, have deeply regretted his contempt of the marvellous stone of which John Ross, the Antiquary, of Warwick, writes. "The earl," says this grave author, "kept a raven in his court; and one day, as he was playing at chess in the garden, the bird," or, as Ross suggests, "a spirit in that form, brought up (eructavit) a stone having the virtue of invisibility. The earl set no value upon it, contrary to the advice of his nobles; and soon after, being arrested by strong hand, he was committed to ward, and finally beheaded."

The king, having put down all opposition to certain measures which he was resolved to carry, by the execution of Arundel, and the murder of his uncle of Gloucester, adjourned his Parliament at Westminster to Shrewsbury, and from thence to Oswestry. An apprehension of tumult among the Earl of Arundel's tenantry in this county, from his violent death, and the seizure of his estates, was probably the reason for making both Shrewsbury and Oswestry the scene of that national assembly. The Parliament met at Shrewsbury Jan. 29, 1397-8, and was designated The Great Parliament. In this regal visit he displayed great magnificence, and entertained the members with a sumptuous banquet, he appearing among the people in his costly royal robes. Whilst in Shrewsbury Richard made Chester a Principality, and annexed to it the Castle of Holt, the lordship of Bromfield and Yale, Chirkland, and various other places in Wales and on the Borders. During the proceedings in Parliament it was ascertained that deadly hatred subsisted between the Dukes of Hereford and Norfolk. These noblemen had been jointly concerned in the impeachment of Arundel and his fellow-sufferers, at Westminster. Norfolk, touched by remorse for his share in the ruin of a patriotic peer, or desirous 
of ensnaring his late confederate, who had charged Norfolk with using words disrespectful to the king, fell into open quarrel with Hereford, who made the matter a subject of public accusation in the Parliament against his antagonist. The king, unwilling that any discourse about himself should be made the subject of open discussion, suddenly closed the proceedings of Parliament, and adjourned to Oswestry. In the assembly there the dispute between the two Dukes was recommenced, and the king resolved that it should be ended by a duel between the belligerent parties at Coventry. The combat did not take place, as the Duke of Norfolk refused to fight; upon which Norfolk was banished from the kingdom for ever, and Hereford for ten years. As a mark of the royal favour, Richard granted, before the Parliament closed, the first Charter conferred upon Oswestry, by which the town was incorporated by the name of "The Bailiffs and Burgesses of Oswestry, infra Palatinatum Cestrioe in Marchia inter Angliam et Walliam." The Charter, which was founded upon the one granted just before at Shrewsbury, exempted the Burgesses from all contributions and exactions whatsoever, throughout the kingdom, the city of London excepted. . It bears date, August 14, 1399.

The close of Richard's kingly rule was near. His love of idle show and magnificence, his delight in popular applause, the buzzing about him of parasites and flatterers, and his indulgence in pleasures, were followed by a brief scene of bitter existence, which ended in degrading humiliation and painful death. The eyes of Henry of Lancaster, Duke of Hereford, had long been directed towards the throne, and he actively employed his agents to place him upon it. The classic historians of Shrewsbury assure us that, either from the disgust occasioned by outrages perpetrated upon the Burgesses, by Richard's body-guard, or disorderly multitudes brought into the town during the sittings of his Parliament, "it is certain that the revolution which placed Henry of Lancaster on the 
throne had the entire concurrence of the inhabitants of these parts (Shropshire). When the Duke proceeded into Wales to circumvent the unhappy Richard, he passed through Ludlow and Shrewsbury, and was joined here (Shrewsbury) by the Lords Scales and Bardolph, Sir Robert and Sir John Legh, and other gentlemen of Cheshire." Richard, after suffering much indignity, was secured a prisoner in Flint Castle, by the great conspirator Lancaster, and from thence was led in the Duke's train to Chester. Here Bolingbroke delivered the subdued monarch to the Duke of Gloucester and Thomas, Earl of Arundel, saying, "Here is the murderer of your father, you must be answerable for him." $\mathrm{He}$ was subsequently conveyed to Pontefract Castle, where he was basely assassinated by a band of armed ruffians, four of whom he killed with a battle-axe before he fell.

The untimely death of Richard caused an immediate change in the government of Oswestry. Its newly-created lord, the Earl of Wiltshire, fell a victim to popular fury, and Thomas, son of the attainted Earl of Arundel, was restored to the manorial rights and dignities of Oswestry. The Earl of Huntington, the king's brother, fled into the county of Essex; but passing through a village belonging to the Countess of Hereford (sister of the deceased Richard, Earl of Arundel), he was discovered, and arrested. The countess apprized the new monarch, Henry, of the capture, and desired him to send to her the young Earl of Arundel, her nephew, that he might witness the mode in which she intended to avenge herself of her brother's death. The Earl of Arundel posted to the place where Huntington was prisoner, and loaded him with reproaches. The countess delivered the captive nobleman, bound with chains, into the hands of eight thousand of her vassals, whom she called together for the occasion. The wretched prisoner, struck with terror at the preparations made to take away his life, sued for mercy, and protested that he had not committed the foul act of which he 


\section{EXECUTION OF HUNTINGTON.}

was accused. Had the countess restrained her rage, and listened to reason and justice, she would have found that Huntington was not a guilty murderer, but that Richard, Earl of Arundel, was brought to the block mainly by the treachery of the Earl of Nottingham. Heedless of his protestations and cries for mercy, she commanded her vassals to cut him to pieces. His assembled executioners are said to have taken pity upon him; whilst the countess and young earl strenuously urged his death. Maddened by rage, she exclaimed, "Curse on ye all, villains; you have not the courage to put a man to death." This violent exclamation roused an esquire, who offered himself as executioner. $\mathrm{He}$ seized the hatchet, and approached Huntington, but was so touched with his tender complaints, that he trembled with emotion; and returning to the countess, his eyes being filled with tears, he said, "I would not put the earl to death for all the gold in the world." The countess, full of indignation, looking at him "unutterable things," exclaimed, "Do what thou hast promised, or thy own head shall be cut off." When he heard this he was so afraid that he knew not what to do, and approaching the earl again said, "Sir, I entreat your pardon; forgive me your death." He then struck him a violent blow on the shoulder, which felled him to the ground. Huntington sprang up again, and said, "Alas, man, why do you treat me thus? For God's sake kill me more easily." The esquire then struck him eight times on the shoulder, being so terrifier that he could not aim his blows at the neck. Another blow followed, which fell on the neck, when the wretched nobleman, suffering pain and agony from his cruel treatment, cried out, "Alas, dear friend, have pity upon me, and free me from my pain." The executioner then seized a knife, and cut the Earl's throat, separating his head from the body.

The Glyndwr or Glendower insurrection arose about this period, and the town of Oswestry greatly suffered from it. 


\section{THE GLYNDWR INSURRECTION.}

Owain Glyndwr was descended on the mother's side from Llywelyn, the last sovereign Prince of Wales, his father, Grufydd Vychan, having married Helen, a grand-daughter of that puissant chieftain. He studied the law at one of the Inns of Court in London, and finally was admitted as a barrister. He may have quitted his profession, for we find he was appointed an esquire to Richard II., to whom he was devotedly attached, and whose fortunes he followed even to Flint Castle, and till his royal master's household was dissolved. He had been knighted by King Richard, and was married early in life to Margaret, daughter to Sir David Hanmer, of Hanmer, in Flintshire, one of the Justices of the Court of the King's Bench. His resentment against Henry IV. was strong and implacable. He had suffered deep private wrongs from the usurpation of the king, and burned with indignation to avenge himself.

Owain Glyndwr's sudden appearance as a military leader of his countrymen roused their ancient martial spirit, and thousands flocked to his standard. In the year 1400 the town of Oswestry was burned, the Welsh having attacked it ; and in 1403 Owain Glyndwr assembled his forces in the town, that he might join Lord Percy (surnamed Henry Hotspur) against the king. The Welsh leader dispatched to the "tented field" his first division only, amounting to 4000 men, whose prowess was distinguished on the day of battle. The great body of his troops, about 12,000 in number, did not approach nearer than Oswestry, they having been detained at the siege of Kidweli Castle. It is thought by some writers, that Owain did not remain inactively at Oswestry. Gough, the historian, mentions, that about two miles from Shrewsbury, where the Pool road diverges from that leading to Oswestry, "there stands an ancient decayed Oak Tree, of which there is a tradition, that Glyndwr ascended it to reconnoitre; but finding that the king was in great force, and that the Earl of Northumberland had not joined his son, he fell 


\section{THE BATTLE OF SHREWSBURY.}

back to Oswestry, and immediately afterwards retreated into Wales."

In the "Beauties of England and Wales," the Shropshire history edited by Mr. Rylance, we find the following passage on Glyndwr's alledged abandonment of Hotspur "at his utmost need :"- "The army of Glyndwr, amounting to twelve thousand men, had remained inactive at Oswestry during the battle. There is a tradition that he himself quitted that place in disguise, and hastening to Shrewsbury, hid himself in a gigantic oak, which commanded a full view of the field; and that after witnessing the discomfiture of his friends, returning with speed to Oswestry, he withdrew his forces into Wales, whither he was pursued by Prince Henry." Hulbert, too, in his "History of the Town and County of Salop," referring to the famous battle, says, "Owain Glyndwr beheld the battle of Shrewsbury, instead of sustaining, by his arms, the cause of his ally, the gallant and intrepid Hotspur." Another writer on this memorable event declares, that had Glyndwr brought up his reserved troops when Hotspur by his impetuous onslaughts was within an ace of victory, or when the brave warrior was slain, the battle would have been won, and the royal forces entirely routed. Taking these allegements to be truths, Glyndwr perpetrated a baseness which all faithful men must condemn.

Many writers have taken pains to solve the question, "Did Owain Glyndwr act merely as an idle spectator at the battle of Shrewsbury; or did he actually lead his corps de reserve to Shelton, to aid the gallant Hotspur ?" No author that we have read has settled that doubtful inquiry. Owain's hatred of Henry, and his ardent efforts to give freedom to his countrymen, with his chivalrous bearing in the rebellion he had created, would suggest no evidence that Glyndwr was pusillanimous ; and yet history furnishes alleged facts strongly reflecting upon his heroic spirit, and almost charging him 


\section{THE BATTLE OF SHREWSBURY.}

with craven cowardice. To conclude that Glyndwr was actuated by base and unmanly curiosity in perching himself upon a branch of the Shelton Oak would be to brand his name with infamy; and yet, if he 'were espying the battle from that famous tree, his troops being close in reserve, but not in action, an accusation no less severe must ever rest upon his character as a chieftain and a man. On this interesting subject, which will always engage the attention of historical readers, a poet of bright fancy and manly sentimentDovaston of Westfelton-has given sarcastic expression to an opinion, in a Miltonic sonnet on the Shelton Oak, that Owain Glyndwr, at the battle of Shrewsbury, was a traitor to gallantry and faith :-

"Tradition says, and why not trust Tradition,

When many a haunt breathes, hallowed by her song,

From this Great Oak, backed by twelve thousand men,

Wrung at their country's wrongs and murdered king,

Glyndwr, the wise, the bountiful, the brave,

Beheld young Percy fall : and conquest crown

The perjured Bolingbroke.--Bright youth, he cried,

Thy spur is cold. One thoughtless act hath lost

An Empire's tide. Mark what the great have said-

'The better part of valour is discretion,'

For safe on prudence every good attends."

"The Battle of Shrewsbury" is not only "clad," as the same poet fancifully describes, "in cold-hearted History's homely weeds," but "garlanded with Avon's dewy flowers." The conflict is part of the history of this district; and the narrative we subjoin, from the able pens of the historians of Shrewsbury, will attract the attention of all who value "pure English, undefiled :"-

"Of the famous and severely-contested battle which ensued under the walls of our town, the awful prelude to so many more between the rival houses, through the remainder of the century, we have five contemporary and perhaps independent narratives; but one of them is a mass of errors, and another 


\section{THE BATTLE OF SHREWSBURY.}

extremely succinct, and of the others only one is circumstantial: nor is any of them sufficient to satisfy the minute curiosity of the local historian : but the best account that can be drawn from a comparison of the whole, supplied in some instances by a consideration of the ground, and in a few others by modest conjecture, shall be laid before the reader as the conclusion of the present chapter.

"We are unable to trace the progress of Hotspur's long march from the North to Shrewsbury, a journey of not less than 250 miles. He probably set out in the beginning of July; and skirting along the eastern side of Cheshire, where his army received a considerable augmentation, passed through Stafford, and was joined there by his uncle the earl of Worcester. The king, aware of his intention to gain possession of Shrewsbury, and desirous of cutting off his junction with Glendower, pursued him with hasty marches. We find his majesty on the 16 th of July at Burton-upon-Trent, and

- on the 17th at Lichfield: whence, finding that he could not overtake his enemy, he hastened on to reach Shrewsbury before him. He would naturally take the Watling Street road, and enter this town over the Abbey Bridge. The route of Hotspur was more to the north, in order to keep up a communication with the Severn, so important for his junction with Glendower. In all probability he marched through Newport, by High Ercall and Haghmond Hill; and hoped to gain admittance through the North or Castle Gate. The king arrived just in time to save the town: he entered it only a few hours before Hotspur, who reached the Castle Foregate on the evening of Friday, July 19th, and the king's forces could not have advanced from Lichfield before the morning of that day. They were certainly here before Percy : for, aware of the intention of that young nobleman, and desirous to save the Castle from his attack, they set fire to that extensive suburb, and marched out of the Castle gates to offer him battle. Hotspur, unwilling to bring his army 


\section{THE BATTLE OF SHREWSBURY.}

into action at the close of a toilsome march, and learning, from the royal banner which waved on the walls, that the king was in possession of the town, called off his followers from the attack, and retired to the Bull-field, an extensive common which stretched from Upper Berwick to the East. He thus protected his rear by the woody and impervious precipices extending to Leaton shelf, and had the river not only on his side, but also, if it had not entirely deserted its ancient channel under Cross-hill, (as there is reason to believe it had not, in his front also. This position enabled him likewise to communicate readily over that stream by the ford of Shelton with the forces of Glendower, when they should arrive, as he hoped, on the opposite bank. Here he passed the night in council. His army consisted of 14,000 chosen men, of whom a considerable part were of the county of Chester, at that time eminent for its skill in archery; but, if Hall is correct, the royal army was nearly double that number; for he writes that above 40,000 men were assembled on both parts, and every circumstance of the battle proves that the king was at the head of a very superior force. His situation was, however, by no means devoid of anxiety. He must have been conscious how slender the title was which he possessed to the throne: and how ill-disposed his peerage of the realm were to maintain him upon it. From the Castle he might view, as the dawn arose, the plain which stretched to the north glittering with hostile arms : while the dreadful Glendower was believed to be in full march from Oswestry, to join the rebels with his Welsh forces. But the difficulties of the crisis only sufficed. to call forth his energies and display his talents.

"Henry was himself a distinguished warrior. In earlier life he had, in company with his princely uncle the duke of Gloucester, travelled into the north of Europe in quest of martial glory ; and under the banners of the renowned Teutonic order had made a glorious campaign against the Pagans of Lithuania. He was still in the vigour of life, being much 


\section{THE BATTLE OF SHREWSBURY.}

under forty years of age, and an adversary every way worthy of the gallant Percy ; whom, relying upon the superiority of his numbers, he determined, if possible, to force to an engagement, before that nobleman should receive his reinforcements from Wales or the north. By break of day, therefore, he dispatched, it is probable, a strong force, under the nominal command, for it could be no more, of the young prince, the future hero of Agincourt, but then a youth of fourteen years, to come up with Hotspur at Berwick, if possible. He himself, with the main body, appears to have marched out on the Hadnall road, ready to proceed as occasion might demand, either to the north of Cross Hill and Almond Pool, and close the rebels between his two divisions; or else to advance further on upon that road, where it branches off to Shawbury, with the view of cutting off their retreat, if Hotspur, aware of his design, should attempt to march to the east. It happened as the king anticipated. Hotspur, on his advance, broke up in some disorder, and marched by Harlescot and Abright Hussey to Hately-field, which stretches from thence eastwards. Here, however, finding it impossible to avoid an engagement, on account, as we may suppose, of the obstruction to his retreat presented by the king's movement above mentioned, he made his stand in the rear of a field of peas nearly ripe; behind which he stationed his army, and hoped thereby to deter the king from advancing over a tract which must necessarily impede his operations.

"He then addressed his little army in a short harangue, of which Walsingham has preserved the heads. 'We must desist,' said he, 'from any further attempt to retreat, and turn our arms on those that come against us. Ye see the royal banner, nor is there time to seek a passage even though we wished it. Stand, therefore, with steadfast hearts: for this day shall either promote us all, if we conquer; or deliver us from an usurper, if we fall: and it is better to die in battle for the common wealth, than after battle by the sentence of 
our foe:" and with this, to support the courage of his men by proving his design to fight to the outrance, he dispatched two of his esquires, Knayton and Salvayn, with that strange defiance, in which he loads the king with the most horrid crimes. $* * * *$

"No one has informed us how the king received this furious manifesto. He had something else to engage his attention. He proceeded to marshal his forces, dividing them into two columns, or wedges. Of one of these he took the command himself, and entrusted the other to his son. The front rank of his own column was led on by his nephew the young earl of Stafford, a soldier of conspicuous valour, on whom he had that morning conferred the high office of constable of England, recently enjoyed by the earl of Northumberland. Previous to the final onset, the king, in compliance with the customs of chivalry, bestowed the honour of knighthood on certain of his most distinguished esquires. Hotspur, perceiving that an engagement was unavoidable, called for his favourite sword. His attendants informed him that it was left behind at Berwick, of which village it does not appear that he had till then learned the name. At these words he turned pale, and said, 'I perceive that my plough is drawing to its last furrow, for a wizard told me in Northumberland that I should perish at Berwick: which I vainly interpreted of that town in the North.' His courage did not, however, yield to the impressions of superstition; he rallied his spirits, and arranged his troops with his usual ability: assigning their respective stations to his uncle Worcester, the Scottish earl of Douglas, his recent captive at Halidown, sir Richard Venables, baron of Kinderton, Hugh Brow, Hugh Vernon, and others. His troops appear to have been chiefly stationed on the north side of the spot now occupied by the church in a field still called the Hateleys : on the east side of the church is a field denominated the King's croft, in which, it may be presumed, were ranged those which the king commanded in person. 42 


\section{THE BATTLE OF SHREWSBURY.}

These positions exactly agree with the objects which we have assigned above to the respective leaders; and lend, it is hoped, some confirmation to the conjectural part of the preceding narration.

"While the hostile armies, drawn up in battle array facing each other, waited, with mute expectation, the sound of the trumpet, the dreadful signal for combat, two venerable divines, 'Thomas Prestbury, lord abbot of Salop, and the clerk of the privy seal, advanced out of the royal army, and proceeded towards that of Percy. The king, desirous to spare the blood of his subjects, offered him and his adherents pardon and peace, and redress of all grievances of which they could justly complain. Hotspur was touched by these unexpected overtures, made under circumstances of such numerical inequality, and requested his uncle of Worcester to repair to the royal presence in company of these holy men, and state the grounds on which he had taken up arms. The king, we may suppose, was in his turn somewhat softened by the sight of the earl, who had been so recently engaged in the domestic office of governor to the prince of Wales ; and a recollection of the obligations he had received from the Percy family might mix itself with his other reflections. It is certain that to the remonstrances of Worcester, delivered in a fierce and haughty tone, he listened with respect, and replied with a condescension which, in the opinion of the spectators, was somewhat unbefitting the royal dignity. A contemporary writer has preserved, though with a mistake of the person, the dialogue supposed to have passed between them. The king ' counselled him to put himself on his grace.' To which the other replied, 'I trust not in your grace.'- 'I pray God,' rejoined the king, 'that thou mayest have to answer for the blood here to be shed this day, and not I. March on standardbearer!' and the battle was set.-It is certain that the stern temper of Worcester rejected all attempts at conciliation: he was conscious how deeply he had been engaged in fomenting 


\section{THE BATTLE OF SHREWSBURY.}

the quarrel; and, on his return to his friends, he misrepresented the demeanour of Henry in such a manner to his nephew, that the latter, with whatever reluctance, was compelled to relinquish all hopes of accommodation. At length, therefore, much of the day having been consumed in these fruitless negociations, both parties flew to arms, and the air was rent with the war-cries of 'St. George' on one side, and 'Esperance Percy' on the other. In the meanwhile, Glendower had advanced as far as Shelton on the opposite bank of Severn, where he awaited the issue of the contest, determined to proceed or retire according to its event. He is said, by the constant tradition of the country, to have ascended there the branches of a lofty oak, whose venerable trunk yet remains, for the purpose of viewing the battle; at least of gaining, from personal inspection, the earliest intelligence of its event.

"The fight began by furious and repeated volleys of arrows from Hotspur's archers, whose ground, as may be seen, greatly favoured that kind of warfare: and they did great execution on the royal army. The king's bowmen were not wanting in return, and the battle raged with violence. The military art had not yet attained that perfection which almost supersedes the effect of individual exertion; and Hotspur, with his associate Douglas, bent on the king's destruction, rushing through the midst of the hostile arrows, pierced their way to the spot on which he stood. To adopt the vivid language of a contemporary, 'in the ardour of his spirit, he assembled a band of thirty warriors, broke into the royal army, and made a great alley in the midst thereof,' (such was the terror which his presence inspired) ' even to the stoutest of the king's guards.' Monstrelet says, Henry was thrice unhorsed by the Scottish earl, and would have been taken or slain had he not been defended and rescued by his own men. And the fortune of the day would have been forthwith decided, if the Scottish earl of March had not withdrawn him 


\section{THE BATTLE OF SHREWSBURY.}

from the danger; for the royal standard-bearer was slain, his banner beaten down; and many of the chosen band appointed to guard it (among whom were the earl of Stafford and sir Walter Blount,) were killed by these desperate assailants,while the young prince of Wales was wounded in the face by an arrow. In short, notwithstanding all the exertions of the royalists, victory seemed inclined to favour the rebel army, who fought with renewed ardour, from an opinion naturally derived from the overthrow of his standard, that the king himself had fallen, and animated each other to the combat with cheering and redoubled shouts of 'Henry Percy, king! Henry Percy, king!"

"In this critical moment the gallant Percy, raging through the adverse ranks in quest of his sovereign, fell by an unknown hand; alone, and hemmed in by foes. The king lost no time to avail himself of this event. Straining his voice to the utmost, he exclaimed aloud, 'Henry Percy is dead!' The sound was heard by either army: into those it struck dismay, while these it animated and encouraged. The rebels fled in every direction, nor could the king, anxious as he was to terminate the slaughter, restrain the impetuous pursuit of his own troops, till the flower of Cheshire, two hundred knights and esquires (besides pages and footmen) were slain. Douglas broke through, and endeavoured to escape in the direction of Haghmond-hill: being closely pursued, and leaping from a crag, he experienced a severe injury, and was captured: but the king, in admiration of his valour, set him at liberty. The loss in both armies was great. * * * * An ancient manuscript rates the number of gentlemen at two thousand two hundred and ninety-one, besides commons. They were chiefly buried, says that authority, in a great pit, the dimensions of which are there specified, and over which the present church of Battlefield was afterwards erected: but many are stated to have lain dispersed in various directions for the space of three miles about the field of 
battle: a fact which confirms what has been said above of the desultory nature of the conflict. Others, of the most distinguished rank, were interred in the neighbouring town, chiefly in the cemetery of the Dominican or St. Mary's Friars.

"The body of Hotspur was at first delivered to his kinsman lord Furnival for interment, and it was by him committed to the ground with the suffrages of the church, and with all the honours which, in that haste, could be procured as due to his rank. It is painful to reflect, that the king afterwards repented him of this generous attention to the remains of deceased valour. He caused the corpse to be taken out of the tomb in which it had been laid, and to be placed between two mill-stones in the public street, near the pillory; where, as if he feared lest the general sympathy should rescue it from its ignominious situation, it was kept under military guard, till the head was severed from the body, which was divided into quarters, and transmitted to several cities in the realm."

Thus closes this circumstantial and able description of the celebrated battle of Shrewsbury ; an event so interesting in the annals of the county, that we make no apology for having transferred so detailed an account of it to our pages. A nobler theme could not well be conceived for the lay of a minstrel. "The characters of the leaders, both of the royal and of the rebel party, the chivalrous spirit of the times in which they lived, and the magnitude of the cause that roused them to arms, are circumstances highly susceptible of poetical description, while the train of incidents from the very origin to the termination of the feud, is of that romantic east which requires little embellishment from fiction. There is indeed one objection which may have deterred our later Poets from the undertaking; it is, that the ground which Shakspeare has trod is sacred; but without any violation of the reverence due to his memory, it may be wished that this magnificent subject had also been celebrated by the muse that sang the tale of Flodden Field." 


\section{THE THIRD CHARTER.}

We have already stated that on the deposition of Richard II. the Earl of Wiltshire, recently appointed lord of the Manor of Oswestry, fell a victim to popular fury, and Thomas, son of Richard, Earl of Arundel, was restored in blood. This last-named nobleman was a liberal supporter of the Corporation of Oswestry. In 1406 he gave it a release for $£ 100$ (a large sum in those days,) which that body was indebted to him, in consideration of the distresses which the town had suffered during the Glyndwr insurrection. He also obtained pardon from the king for his vassals in Chirk, Bromfield, and the Manor of Oswestry, for the share they had taken in that rebellion. In the same year with the release he granted a most extensive Charter to the town, containing many matters showing the customs of the times. This Charter ordered, that "neither the lord nor his heirs should confiscate or seize the effects of persons with or without will in the corporation; that no burgess should be compelled to be the lord's receiver-general, but only collector of the issues arising within the borough ; that the burgesses should be discharged from all fees demanded by the Constable of the castle, or any of his menial servants, for any felonies or trespasses committed out of the same liberties, when brought to the prison of the castle; saving that the Constable might receive one penny at his own election, from every mansion-house in the town, and a farthing from every cottage, on the feast of St. Stephen annually ; that the burgesses should be free for the future from all excise of ale, brewed and sold in the town, which had hitherto been payable at the rate of seven-pence for every Bracena cervisice exposed for sale; that they were to be freed from the duty of Amobyr, or Lyre-Wyte; that whoever lived in the house of a burgess, and happened to die there, the burgess was to have a heriot after his decease, in the same manner as the Uchel$w y r$, or freeholders residing on the lands of the lord in the Hundred of Oswestry; that no Shrewsbury ale should be sold in the town without license, while any ale brewed in the 
town was to be had, under the penalty of $6 \mathrm{~s} .8 \mathrm{~d}$.; that none of the inhabitants of the lordships of Oswestry, Melverley, Kinardsley, Edgerley, Ruyton, and the eleven towns, should drive or carry any cattle, corn, or victuals, or other wares, to any foreign fair or market, before the same had first been exposed for sale in the town of Oswestry, under the penalty of $6 \mathrm{~s}$. $8 \mathrm{~d}$.; that none of the lord's tenants should be compelled to pay the redditus advocarii for the security of the castle," \&c. The Amobyr of the Welsh, and the Lyre-Wyte of the Saxons, were fines paid by the vassal to his lord, to buy off the power to violate domestic relations. Pennant gives a different interpretation to the term Amobyr, but does not succeed in giving us its literal and precise meaning. There is one curious fact mentioned in the aforesaid Charter, and which, even in these days must excite a smile. The respective sixand-eightpences of the gentlemen who now study "Coke upon Littleton" was actually prescribed even so far back as the fifteenth century. It would be a still more curious fact developed, were we acquainted with the lord of the Manor's law-adviser when this Charter was granted, because we might perhaps then be able, from the knowledge of that fact, to ascribe the origin, if not honour, of lawyers' six-and-eightpences to the ancient Borough of Oswestry!

According to Pennant, "until the time of the above-mentioned Charter, the lord's Welsh tenants of the Hundred of Oswestry were accustomed by their tenure to keep watch and ward, for three days and three nights, at the four gates of the town, during the fairs of St. Andrew and St. Oswald, with a certain number of men called Kaies; but these treacherously, with others, ravaged and plundered the place. On this the tenants were compelled to pay a sum of money as wages to a sufficient number of Englishmen, as the burgesses should think convenient, for the custody of the four gates; and the Welsh men were for ever to be discharged from that duty. The vassals of the Earl of Arundel in these 


\section{GLYNDWR'S REVERSES.}

parts were of a mixed nature ; either descendants of the Norman followers of Alan, or of the native Welsh, who were most numerous, and bore an hereditary dislike to their cotenants of foreign stock. The Welsh part was called Walcheria, and lay in the upper part of the parish."

Reverting to Owain Glyndwr's career, we see that his escape from the Shelton Oak, at the Battle of Shrewsbury, did not deter him from fresh enterprises. Evidently regardless of the ruin of his allies-they, as Leland tells us, "whom he promised to unite with" at that battle-he continued to infest the English borders, where he committed great havoc, the king being unable, from the want of funds, to resist his aggressions. Owain's marauding parties committed serious damage to Shrewsbury and several of the adjoining townships, and extended their ravages as far as Buildwas Abbey, which they wasted with fire, so that divine service was for a time discontinued, and the monks were reduced to the greatest poverty. At length Henry directed a writ to Edward Charlton, Lord Powys, to raise forces with which to subdue the renewed rebellion; and similar orders were sent to Lords Arundel and Grey, and Sir Richard L'Strange, Lord of Knockin, Ellesmere, and other bordering manors. Glyndwr had despatched to Shrewsbury two of his best officers, Rhys Ddu and Philipot Scudamore, to command the insurrectionary party ; but Lord Powys, having promptly obeyed the orders of his sovereign, fortified several castles, and speedily took as prisoners the above-named two leaders, and they were both soon afterwards executed in London. Holinshed says, that "Glyndwr himself in the same year, dreading to show his face to any creature, and finally lacking meat to sustain nature, for mere hunger and lack of food miserably pined away and died." He was living, however, six years later, but in a state of concealment, chiefly at the house of one of his daughters, married to a gentleman of Herefordshire named Monnington. In July, 1415, the new king Henry V., 
anxious to leave his country in tranquillity before he engaged in the war with France, offered a pardon to Glyndwr; and this would probably have been accepted by the Cambrian chieftain, had not the negotiation been interrupted by his death, which occurred September 30th, 1415, in the 61st year of his age. It is said that David Holbetch, Steward of the manors of Oswestry, Bromfield, and Yale, and founder of the Oswestry Free Grammar School, took a distinguished part in this negotiation, and obtained the promised pardon for Glyndwr. Tradition states that he was buried in the churchyard of Monnington-on-Wye.

With Glyndwr ceased most of the troubles and calamities which had too long afflicted the English and Welsh Borders. The superstitious charm with which Owain's name had been invested by his countrymen soon faded away, and his life, though startling in a rude and ignorant age, soon proved that he was "in the common roll of men!" Shakspere was justified in creating him, poetically, as self-idolatrous, for his daring incursions and fiery movements indicate that he believed himself to be of the meteoric class, to curb oppression and give liberty to the enslaved. For years after Glyridwr's fall Oswestry, for aught that history tells us to the contrary, lay in comparative repose, entirely free from foreign aggression. Intestine feuds and disorders seem to have been the chief disturbers. The Welsh were arrayed against the English, and the latter appear to have had no less enmity against their Cambrian neighbours. To Pennant's industrious and accurate research we are indebted for the scanty notices collected of the history of this period. Among the records of the Drapers' Company of Shrewsbury, he tells us there is the following order:-"25 Eliz. 1513. Ordered, that no Draper set out for Oswestry on Mondays before six o'clock, on forfeiture of six shillings and eightpence; and that they wear their weapons all the way, and go in company-not to go over the Welsh Bridge before the bell toll six." 


\section{WELSH CLOTH MARKET.}

However numerous and fierce marauders were in the days here referred to, it would seem that peaceful employments were nevertheless pursued by the inhabitants of Oswestry, and that their manufactured cloth was of so good a quality as to be held in high repute among the Shrewsbury Drapers. The "contests, robberies, and disturbances in the Marches of Wales" still continuing with unabated force, and both Welsh and English seeming to have considered everything as lawful plunder which they could seize in each other's territory, the Stewards, the Constable, and Lieutenant of Oswestry and Powys entered into covenants in the year 1534, to restrain these plundering excursions. It was agreed, that "if, after a certain day then fixed, any person of one lordship committed felony in the other, he should be taken and sent into the lordship where the offence was committed, to receive punishment; and that if any goods or cattle were stolen from one lordship and conveyed into the other, the tenants and inhabitants of that lordship should either pay for the same within fifteen days, or otherwise four principal men should remain in bail, a main-prize, till they were either paid for or recovered."

Notwithstanding these rigorous measures, the evil still continued; and so alarmed were certain of the inhabitants of Shrewsbury, and regardful of the safety of their fellow-burgesses who had to visit Oswestry market weekly, that prayers for their preservation were offered up in one of the churches, on Monday mornings, before they started on their perilous journey. A timid gentleman, William Jones, Esq., left to the Drapers' Company “one pound six-shillings and eightpence, to be paid annually to the Vicar of St. Alkmond's Church, for reading prayers on Monday mornings, before the Drapers set out for Oswestry market!" Pennant informs us that at this period "Oswestry was the great emporium for Welsh cloth; a privilege to which it was well entitled from its vicinity to those districts of Wales in which that important branch of commerce was manufactured, at a period 51 
when the English trader could not, with any degree of safety, trust himself in the Principality. To this town (Oswestry) the Drapers of Shrewsbury repaired every Monday. We learn the fact from a curious MS. Chronicle of the last-mentioned town, which relates that 'on Monday, Dec. 5th, 1575, the Drapers of Shrewsbury had like to have been robbed, if they had not been privately warned; but the bailiffs and a great company went, strongly armed, upon their usual trade toward Oswestry. The robbers proposed to rob them in the dale between Shelton and Shrewsbury, and lay over night in Master Sherar's barn, on the other side of the water.' The whole narrative, which is told much at length in the Chronicle, exhibits the unsettled police of a country slowly emerging from a state of barbarism, and strongly reminds the reader of the inimitable scene at Gadshill, so admirably pourtrayed by our great dramatic bard in the first part of Henry IV." The same writer adds, "notwithstanding, however, this and similar proofs of the general insecurity of the country, the Welsh manufacturer was unwilling to meet the purchaser even half way with his commodities. 'Not satisfied,' says our countryman Dr. Peter Heylyn, in his Cosmography, 'with having fixed the market at Oswestry, they sought to draw the staple more into their own country.' The MS. quoted above informs us, under the year 1582, that it would have been removed thence, 'to the great decay of that town and of Shrewsbury, yf Sir Thomas Bromley, being Lord Chancelor, had not by his great wisdom opened the same to the Queen's Majestie, for which godly deede theye of the said townes are contynewally bownde to praye daylye.' Lord Chancellor Bromley was a Shropshire man, and possessor, by purchase from the Earl of Arundel, of the Castle and Lordship of Shrawardine; he was therefore personally interested in the prosperity of the county, and by his influence at Court enabled to promote it." It would further appear, that the market was continued at Oswestry, so that it is likely that Lord Bromley's interposition at Court prevailed. In 1585 the Welsh 


\section{PENTRE-POETH.}

cloth market was removed from Oswestry to Knockin, the plague having broken out in this borough, and destroyed " three-score and four persons, and no more ;" according to the parish register. The plague continued from April to August, when it entirely disappeared, and the market was held, as before, in Oswestry.

Oswestry was visited with other calamities some few years before this period. In 1542 a fire broke out in the town, which was so destructive, that " two long streets with great riches" were consumed; and in 1567 there was another fire, which destroyed "seven-score within the walls, and three-score without." The suburb still known by the name of Pentre-Poeth (the burnt end of the town) suffered severely, and may have derived its designation from this destructive fire; or, as Price intimates, from the frequent fires that may have occurred there during the conflicts between the Welsh and English. These accidents were looked upon, at the time, through astrological telescopes, by Camden, the historian, and a Dr. Childrey. They both gravely ascribed these events to astrological phenomena, Camden seriously remarking, "that the eclipses of the sun in Aries have been very fatal to this place; for in the years 1542 and 1567, when the sun was eclipsed in that sign, it (Oswestry) suffered much by fire!" After reading such absurdity as this from men professing to be learned, we have reason to be thankful that we are living in a more enlightened and scientific age.

A few years before the conflagration last referred to, the town was visited by a no less alarming evil. In 1559 pestilence consigned to the grave, within one year, more than five hundred of the inhabitants. The disease which thus afflicted the people is stated to have commenced with profuse perspiration, (from which it was called " the sweating sickness,") and to have continued until the death or recovery of the patient. Its operation was quick and powerful, and cure or death occurred within twenty-four hours. Those persons who were seized in 


\section{CROES WYLAN.}

the day were put to bed in their clothes to wait the issue; and those seized in the night were desired to remain in bed, but not to sleep. The desolation of the town during the long continuance of the plague is described in affecting language by the writer of the clever historical sketches, on the History of Oswestry, that appear in Mr. Roberts's publication, entitled "Oswald's Well:"- "It was then that Croeswylan received its name. Croes wylan, or the Cross of weeping, was there erected, the base of which still remains to be seen. To this, with superstitious reverence, all the people resorted. The diseased and dying sought in grief beneath its sacred shadow a preparation for the doom to which they were appointed, and there they languished till that doom was fixed. Before it, the whole and healthy ones confessed and deplored their sins, and deprecated the vengeance of heaven. 'Throughout the succeeding century this foul contagion lurked on our shores, and at intervals visited our town, converting it into a vast charnel house. Its attacks were so insidious and sudden that the glow of health suffered no process of removal, but instantly fled, as scared and affrighted on the approach of the fell devourer. During its presence no sights were to be seen but the wan and sickly visage of those who were dying, or the panic-stricken gaze of the man yet uninfected, almost delirious with alarm, and starting from the touch of the dearest friend of his heart. The air was rent with shrieks and laden with lamentation. Death alone seemed contented and satisfied, and sat like a monster unmoved as he banqueted on hundreds of his victims. All commerce was at a stand-still. Every house was locked, the inmates scarcely venturing upon a communication with each other, much less exposing themselves to contact with those without. With foreboding reluctance they breathed the breath of heaven, pregnant as it was with the seeds of death. If one of their number was attacked, no consideration of friendship or kindred spared him the aggravation of being hurled into the street, there to await the regular anival of the dead-cart. That sad accompani- 


\section{RECORDS OF THE PLAGUE.}

ment of the contagion, the gibbet of the scene, rolled sullenly along the death-smitten streets upon its gloomy mission, and never returned without the sad evidences of the rapid progress of the desolating scourge. In the ears of the expiring it must have sounded like the toll of the passing bell, the knell of their speedy departure. Upon it, whether dead or just gasping for life, the diseased victims were heaped, and hurried off to the brink of a huge pit, dug, probably, in a corner of the Old Churchyard, into which they were remorselessly thrown. Everything bespoke the presence and working of a mighty power, in league with 'the King of terrors.' All human ties were forcibly disrupted, every human sympathy was sacrilegiously immolated, until the people were reduced to that extremity of sadness, in which life is burdensome for its sorrows, and death terrible for the grim and ghastly shroud in which it lies hid."

The market was held, during the Plague, at Croes wylan, that the people from the surrounding country-places should not visit the town, and thereby suffer from the infection. No doubt that with the dreadful scourge stalked, hand in hand, gaunt poverty. It may be easily imagined that the poor suffered severely from the sickness, and that many of them required relief. We have some testimony before us that the public authorities of the time sympathized with the sufferers. The following extracts from the "Accompt of Richard ap Lley, Muringer of the town of Oswestr, for and from the xvj day of September, in the 2nd yere of our sovraynge Lady Elizabeth," show how pecuniary aid was rendered to certain parties :-

"The sayde accomtante doth asc alowaunce for rent bayted to the Towlers (toll-takers) for one qr. in considracion of the PLAGE :

Fyrst to the executors of John Vyghan Allso, \&c. rent bayted to Thomas ap Rc. for Wolyws-gate Allso, \&c. to David Glover the elder, for Newe-gate Allso, \&c. to Wyling Lloyd, for Betresce-gate s. d.

- $\mathrm{xx} \ldots$

- $\quad \mathrm{xx}$..

- $\quad$ xiij iiij 


\section{ALLOWANCE TO THE SUFFERERS.}

Allso, \&c. to David ap David, for Blak gate

Allso, \&c. rent of Crofft-pystil, in the hande of Rc. ap Mrdyth, dyssessed

Allso, \&c. money payde for wrytinge of a suplycacion to my lord of Arundell

Allso, \&c. for Lewys Tayler, and Guttyn Furbur, beinge unpayde for setting of stales, by reason of the Plage - _ - -

Allso, \&c. for Rc. Lewther, for one qr. beinge absent from the towne

Tanners. Allso, \&c. for a qr. rent unto tanners beinge apsent in in tyme of the plage; and fyrste, Thomas Baker ( 2 other similar items)

Glovers. Itm. The sayde accomptaunt dothe asc alowaunce for them that are deade or fled, and them that are in decaye; and fyrst, Thomas ap John Wyling, beinge a poore man (five others fied, \&c.)

iiij ij

ij ..

.. xij

..xiiij

.. $\mathrm{xx}$

..xiiij

Buchers. Imp. the sayde accomtant, \&c. Lewys, bucher, that is dead (one for the like and 7 fled) -

Corvsers.

Edward Gorg, fled ( 2 others fled) -

.. $v$

.. iij

Backers. David ap sr. Rc. saythe that he dothe not occupey his backhowes, and prayth alowance - David Bobyth hathe ben longe secke, and asc alo .. vi .. $\mathrm{ilj}_{\mathrm{j}}$

Hucksters. Jonet vrch. David ap Morys asc alowance for a qr. Rent (1 other)

Alle Selers. Edward Lloyd praythe alowance for a qr. .. $\mathrm{x}$ David Glover the elder, in lycke manner - Richard Salter was longe sycke, and praythe alowance

Thomas Glover praythe alowaunce for half a yere; aledginge, that he sold no alle for that space (3 others)

Payments for the provision of the genrall Feast unto the Coo-burgesses according to the aunsient costom, holden the vth day of Desember, in the thryde yere of the raynge of our sovraynge layde Ellizabeth, by the grace of God quene of England, \&c. at the making of this accompt:

Whete. Fyrste, the saide accomptaunt hathe payde for ii stryckes and a hoope of whette for brede and for peys

s. $d$.

Maullt. Allso payde for iii strycke of maullt xj $\cdots$

Boochers. Allso payde for a qr. and ii rybes of byff _ _ _ vj viij Allso payde for mytton for to make peys for this feast $i j$ vj $\ldots \ldots \ldots \ldots \ldots \ldots \ldots$ for $\mathrm{iij} l b$, ressyns $\quad$ - $\quad \ldots x i j$ 


\section{FAMINE.}

Cloves, \&c.Allso payde for cloves, masses, aud saffrone _ _ _ _. vj Allso payde for synamon and sugr. - : $\quad$ - $\quad$ - . . vij

Itm. pd. for buttr. spent at this feast - _ $\quad$ - $\quad \ldots$ viij

Chese. Allso payde for chesses - - - - - ij ix

Nyttes, \&c.Allso pd. for appells and nyttes $\quad-\quad \quad-\quad \quad-\quad \ldots x v j$

Saullt. Allso payde for a hoope of sallt for the byff - $\quad$ - . $\mathrm{x}$

This Accompt was made before us, the persons under-named, then Bailiffe of the said Towne,

John STANNey, Thomas Evans.

With these awful calamities the people endured severe privation, both as to food and clothing. Provisions had risen so enormously in price as to place even the coarsest food beyond the reach of the poor. We are told that so deficient were the working-classes of the commonest provision, that they were glad to resort, for subsistence, to horse-bread, composed of beans, oats, and bran. "The good old times" are too frequently quoted as periods of comfort, compared with the present days; but such facts as have been now related must convince every Englishman of right feeling that, howeverhumble his lot, he still possesses "a goodly heritage."

For a considerable time no event occurred in Oswestry worthy of detailed notice. In the 42nd of Elizabeth, Coke, Attorney-General, acknowledges all the liberties and franchises of Oswestry, by an order that all further proceedings on the part of the Crown, on a writ of Quo Warranto against the Bailiffs and Burgesses of Oswestry, should wholly cease. In 1603 a dispute took place between the Bailiffs, Burgesses, \&c. and the Earl of Suffolk, then lord and owner of the town and manor, the former body having, in numerous assembly, resolved to maintain the rights and privileges granted to them by Richard II., and confirmed by their "late sovereigne of famous memorye, queene Elizabeth." A petition setting forth their grievances, mainly caused by the Earl of Suffolk's steward, had been presented by them to the Lord President of the Marches ; to which Lord Suffolk replied as follows :- 


\section{SUFFOLK'S LETTER.}

\section{"To his good freinds, the Burgesses and Townesmen of his Towne and Manor of Oswester :}

I HAVE of late receaved a Letter from my hon ${ }^{\text {ble }}$ good Lord and freind, the L. President of Wales, $w^{\mathrm{ch}}$ declared unto mee, a great desire in his $L^{p p}$ to give some satisfaction to you uppon a Peticon given him from $\mathrm{yo}^{\mathrm{r}}$ Towne, as exceptinge against the Course wch Mr. Lloyd, my Officer, healde with you. Nowe you must knowe, that I doe, and will avowe him in such things as he, in his discreation, shall find to bee profitable for mee $\mathrm{w}^{\mathrm{ch}}$, perchaunce, may bee displeasinge to you, but herin you may further wronge $\mathrm{yo}^{\mathrm{r}}$ selves then you are aware off; for yf you shall deny to yeald mee thoes Rights \& Proffits that are due unto me, as Lord of the Manor, you must then knowe, that I doe look for at Mr. Lloyds hands such a resistance of $\mathrm{yo}^{\mathrm{r}}$ wills as I may not bee prejudized thereby : \& I knowe his understandinge $\&$ discreation is such, as he would not drawe mee into frivolous and needles questions. - Therefore I must tell you, that yf you have refused the duties whch belonge unto mee, that I will execute my remedies as the lawes of the Land will allowe mee. But, becawse I wolde not be thought rigorous, and that yt may appeare that my L : President hath the powre of an honorable 8 kind ffreind in mee, $I$ am contented that yf you doe sende upp to the Tearme at Winchester, such as shall have powre to followe the cawse in the behaulf of you all, that then the questions $w^{\text {ch }}$ are risen between the Steward $\&$ you shall, yf yt may be, have an end; by Councill chosen of each syde; $w^{\text {ch }}$ Course shall please mee well : but yf yt happen otherwise, the fault shall not be myne, for I desire not contencons ; but then of necessety, Lawe must determyn them. In the meane tyme, I charge you all to carry $\mathrm{yo}^{\mathrm{r}}$ selves respectively and duetifully to my Officers; for you must learn to obey, yf you will desire to be obeyed; $w^{\text {ch }}$ you, being a Corporate Towne, should principally desire. And soe I leave you for this tyme, untill I heare further from you. From the Court at Wylton, this 25th of October, 1603.

$\mathrm{Yo}^{\mathrm{r}}$ Lovinge freind $\&$ Lord,

\section{SUFFOLKE."}

James I. in 1616, granted a Charter to the town, thus removing " divers doubts and ambiguities" which had " arisen concerning the ancient liberties, francheses, \&c., of the town and borough of Oswaldstre," and extending their liberties and privileges, as well as confirming them a body corporate, by the name of "the Bayliff and Burgesses of Oswestry, in the Countie of Salope." 


\section{PLOT TO REMOVE THE MARKET.}

About this period a heavy blow was struck at the commerce of the town, by the Drapers of Shrewsbury (a reference to whose complaints and apprehensions has already been made), "who weary," says Pennant, "of their weekly journeys to Oswestry, determined to transfer the market to their own town, from that in which Queen Elizabeth had established it. But this attempt proved in the first instance abortive. The Lordship of Oswestry was enjoyed at this time by Thomas Howard, Earl of Suffolk, to whom it had been granted by the late queen, in the 43rd year of her reign. He was in great favour with James, in whose Court he held the office of Lord Chamberlain, and to whom he had recently recommended himself by his vigilance and promptitude in the discovery of the Gunpowder Plot. Possessed of the highest notions of the privileges of the peerage, and jealous of the infringement of his rights by the traders of Salop, he issued his mandate to them by one of their own body,-Arthur Kynaston, merchant of the staple, a younger brother of the house of Ruyton,-to desist from such attempts in future. Their answer is recorded in their own books : it is entitled 'The copy of a letter sent by the Company to the Earle of Suffolk, Lord Chamberlain of his Majestie's househoulde, ye 24th June, 1609.' ' 'Right Honerabell,-Your letter bearing date the second of this June, by the hands of Mr. Kiniston wee have received: wherein ytt appereth yor Lordship was informed that wee the Societie of Drapers wentt aboute by underarte and menenesse to withdraw your markett of Walsh clothe from your towne of Oswester;' and they proceed to exculpate themselves from the charge in those phrases of submission which were in that day the established usage of inferiors in their addresses to those above them. This was their tone during the plenitude of the Earl's power, which, five years after the date of this letter, received a great increase by his appointment to the exalted post of Lord High Treasurer of England. During this time we may be sure 


\section{ITS SUCCESS.}

' the market for frize and cottons continued, where, according to Heylin, it was originally fixed, at Oswestry.' But in 1618, the King's necessities caused an enquiry into the management of the treasury, and Suffolk, whose unbounded expenses in his magnificent palace at Audley-End, had brought him into pecuniary difficulties, was fined by the Court of Star Chamber in the vast sum of $£ 30,000$, and dismissed from all his employments. The clemency of James mitigated this enormous fine, but the influence of the Earl of Suffolk was gone; and in 1621 the Shrewsbury Drapers made an order upon the books of their Company, "That they will not buy cloth at Oswestry, or elsewhere than in Salop."

As we have shewn in a preceding page, the struggles of the Welsh, to recover the freedom they had lost, terminated with the death of their last great leader, Owain Glyndwr. "Their wild spirit of independence, and their enthusiasm for liberty," says the eloquent historian whom we have already quoted, "from this period gradually declined. The blood of their beloved Princes was nearly extinct; and their native bravery was subdued, or rendered ineffectual, by their intestine divisions and by their repeated misfortunes. When fierce valour and unregulated freedom are opposed to discipline, to enlarged views, and to sound policy, the contest is very unequal : it is not therefore surprising that the genius of England at length obtained the ascendancy. It was, indeed, an interesting spectacle, and might justly have excited indignation and pity, to have seen an ancient and gallant nation, falling the victims of private ambition, or sinking under the weight of a superior power. But such emotions, which were then due to that injured people, have lost at this period their force and their poignancy. A new train of ideas arises; when we see that the change is beneficial to the vanquished-when we see a wild and precarious liberty succeeded by a freedom which is secured by equal and fixed laws-when we see manners hostile and barbarous, and a spirit of rapine and cruelty, 


\section{THE CIVIL WARS.}

softened down into the arts of peace, and the milder arts of civilized life-when we see this Remnant of the Ancient Britons uniting in interests, and mingling in friendship with their conquerors, and enjoying with them the same constitutional liberties; the purity of which, we trust, will continue uncorrupted as long as the British Empire shall be numbered among the nations of the earth."

We now approach a period in our national history which has ever been viewed, by opposing political parties, in a conflicting spirit. The turbulent elements of

\section{THE CIVIL WARS}

were not allayed until Death had silenced the two great actors in the tragic and murderous drama. The present volume, devoted principally to local history, is not an appropriate organ in which to discuss the merits and demerits of Charles I. and his sturdy rival Cromwell. Charles was doubtless guilty of many gross violations of his prerogative, and plunged into a reckless course of misgovernment, accompanied with galling taxation, which the people, beginning to learn the lessons of liberty, and to understand the genius of the British constitution, would not tamely submit to.

The ill-fated monarch, looking at him through the long vista of two centuries, was greatly to be pitied. The son of a king, who disregarded the instructions of his wise preceptor, Genrge Buchanan, and who, in his rule over the English people, was prodigal, unprincipled, and tyrannical, he ascended the throne with a corrupt education, and urged to despotism and injustice by his infamous minister Villiers, Duke of Buckingham, he speedily exhibited in his regal capacity, a passion for power, which, as Macauley remarks, soon became " a predominant vice; idolatry to his regal prerogative, his governing principle. The interests of the crown legitimated every measure, and sanctified in his eye the widest deviation 


\section{CHARACTER OF CHARLES I.}

from moral rule." Such was the son of a kingly father who was fond of cockfighting, and the brutal pleasures of inebriation, who utterly neglected the affairs of state on the plea that "he should not make a slave of himself;" who sold titles and privileges of all kinds, that his vices might be fed; and who basely deprived people of their patents, after having paid for them to himself. These were only a small portion of the sire's iniquities. What surprise then can be entertained that Charles, his son, walked much in the father's footsteps! Notwithstanding his despotic and infatuated measures, to which all the evils of the civil wars may be traced, yet he had many excellencies; and the closing scene of his unhappy life proved that had he been blessed with a wiser tutelage, and taught to govern with a just and righteous hand, he might have descended into the tomb with virtue and honour, embalmed in the grateful recollections of his country.

Of his powerful rival and successor much has, and still may be said, in his praise and condemnation. His character, however, singular and erratic as it was, was mixed, as that of other men; and whilst he displayed a religious enthusiasm and sanctity in most of his public acts, apparently impressed with the conviction that he "was doing God service" in the course in which he had embarked; yet the troublous events of his life-the fears, anxieties, and weakness of his mortal nature-must have convinced him, if he sincerely believed. in the religion of which he made so loud and trumpet-tongued a profession, that "he had done many things which he ought not to have done, and left undone many things he ought to have done." Now that we look calmly back upon Cromwell's life, we can see much in his administrative policy that elevated the nation during his transient rule, and that has shed its salutary influences even upon the present generation; but the deep, dark spot in his escutcheon-the murder of Charles -a crime which harrows up the feelings, and rouses the indignation of all right-minded men - that foul murder, with 


\section{COLONEL LLOYD.}

all its cruel and inhuman associations, blots out any excellency that he ever did achieve, and stamps his character indelibly as that of a religious, enthusiastic professor only, and not of a Christian man. Charles may have been guilty, and deserving of punishment for his misrule; but we have yet to learn that Cromwell had plenary power to execute the mandate of JEHOVAH, and to have adopted the inspired exclamation, "Vengeance Is Mine!"

"At the breaking out of the Civil Wars," says Pennant, " the whole of Shropshire, with few exceptions of persons and none of places, adhered to the cause of royalty. Oswestry, like the rest, was garrisoned for the king. The town was defended by a new gate and draw-bridge; the castle was fortified very strongly; and to prevent it from being commanded by the church, in case of the capture of the town, the steeple was pulled down, and a part of the sacred edifice was also demolished." The same popular author, with his fervid nationality, and strong royalist principles, adds, with evident pride and delight, "The garrison consisted chiefly of Welsh (a people almost to a man staunch in the cause of their sovereign)." The governor of Oswestry Castle at this disturbed period was a Colonel Lloyd. Edward Lloyd, Esq., of Llanvorda, compounded for his estates, as a royalist, in the sum of $£ 300$; and at the period of which we write (1643) he was in the prime of life, and therefore physically able to assume the important command of Governor of the Castle. Colonel Thomas Mytton, of Halston, near Oswestry, a man well skilled in military art, and of great personal courage, had united as a commander with the Parliamentary forces, and first signalized himself in an assault upon the town of Wem, which he seized and garrisoned; that place soon became the centre from which attacks were directed against the royalist garrisons in the neighbouring towns. Mytton's success at Wem was achieved in the latter end of August, 1643 ; and although he actively assisted the Parliamentary 63 
army in its attacks upon other parts of the country, he frequently visited Wem to concert measures for fresh conquests. In January of the following year, a plan was there determined upon for a sudden and covert attack upon Oswestry. The story is on record that Mytton well knew the bon vivant qualities of the Governor of Oswestry. It was said of this royalist Commandant, that in the social circle he was the life and soul of the company, and that when he entered upon the convivialities of the table, he found it a difficult matter to interrupt the rosy hours by wending homewards. Colonel Mytton might know the frailties of his gallant opponent; and, with a strategetic: art unworthy of a modern general, he devised a scheme for capturing the Governor and seizing the town of Oswestry. The anecdote proceeds to state, that Colonel Lloyd was to be invited to dinner at the house of a neighbouring gentleman; and Mytton calculated that no dinner invitation would be refused by good-humoured Col. Lloyd. The plot included the spread of further net-work, in which the unsuspecting Governor was to be surely caught. His gastronomic and vinous attachments were to be plentifully gratified; and whilst indulging in bacchanalian revels, a military force, under Mytton's direction, was to enter the dining room in which the innocent Governor was carousing, to seize him, vi et armis, take him before his own garrison, in Oswestry, and there compel him to issue orders to his officers to surrender the town and castle. The plot, as we have described it, was partly successful, but eventually failed. Colonel Lloyd accepted the apparently-friendly invitation to dinner; and all went merrily on with him for a brief period. The detachment of troops was sent from Wem to take him prisoner, so that the first act of the drama was nearly completed. Whilst, however, the Parliamentarians were on their way to surprise him, two of their scouts were seized by some royalist friends; they confessed their share in the treacherous plot; the Colonel was apprized of the danger he was in, fled from the habitation of his Judas-like host, 


\section{ATTACK ON THE TOWN.}

reached the "post of honour" which he had so improperly abandoned for the pleasures of the table, and secured from the grasp of his enemies both the town and castle. Colonel Lloyd's misconduct was reported, it seems, to the royalist commander-in-chief, who removed him from his important position, and appointed as his successor Sir Absetts Shipman.

The parliamentary leaders were numerous and powerful, and they were all fired with zeal and enthusiasm in the cause which they espoused. The town of Oswestry was a military post of distinction in their eyes; and to possess it was an achievement " devoutly to be wished." Oswestry stood on a towering height, vigilantly watching the varied movements of the parliamentary hosts, and protecting the communication between the town and Wales. The opposite party were equally active and observant. Colonel Mytton was well acquainted, from his local connexion, with the strength and resources of the town, and brought to his aid, in his meditated attack upon it, Sir Thomas Fairfax, the equal to Cromwell in military tactics. In the month of March, 1644, Fairfax and Mytton, with a strong force under their command, made a sudden attack upon the town, which was gallantly repulsed by Prince Rupert (the King's nephew), who commanded the royalist troops in garrison. This triumph was but of short duration, for the town was attacked in a few months afterwards, and in this renewed onslaught, the parliamentary forces were victors. The Battle of Oswestry, if such it may be called, was fought on the 22nd June. The Earl of Denbigh, a young parliamentary leader of some military talents, and son of a nobleman who had died in defence of the crown, suddenly left the main body of his army, and marched, with his "forlorn hope" upon Oswestry, determined upon taking the town by a coup de main. He reached the vicinity in company with Colonel Mytton, about two o'clock in the afternoon of June the 22nd, the former probably knowing, from the "false brethren," as spies were then called, that 65 


\section{CRANAGE'S DARING.}

the garrison was partly defenceless, the Governor having imprudently gone to Shrewsbury with certain parliamentary prisoners. Denbigh's force consisted merely of two hundred infantry, and two troops of cavalry. The engagement was short and sharp. After a hot affair of about two hours, in which Lord Denbigh's artillery played fiercely upon the garrison with small and great shot, a breach was made in the walls of the town, and the infantry poured in, headed by Major Fraser, with the loss of only one man killed and three wounded. "The New-gate," adds Pennant, "was next demolished by the cannon, when a young fellow, one George Cranage, went with a hatchet, and cutting down the chains of the draw-bridge, enabled the cavalry also to enter. The besieged made an attempt to maintain the Church, but soon finding it untenable, fled to the castle. Hither they were closely pursued, and the pioneers were quickly called in to undermine its walls; in which, we are informed, the skill as well as valour of Colonel Mytton was very conspicuous. He was probably enabled, from his residence in the neighbourhood, to direct the miners to proceed with most effect. But the daring valour of Cranage again anticipated these slower operations. He was persuaded to hang a Buttar (a petard) at the castle-gate! Being well animated with sack, he undertook this desperate attempt, crept with the engine from house to house, till he got to that next to the castle, fastened it to the gate, set fire to it, and escaped unhurt! The gate was then burst open, and the garrison, finding it impossible to make any further resistance, surrendered the castle upon promise of quarter for their lives. * * * * It is greatly to the honour of the victorious commanders that they restrained their soldiers from pillage, at the expense of a gratuity of $£ 500$. One can scarcely err in ascribing this noble and uncommon act of mercy to Colonel Mytton's solicitude for the welfare of his neighbours. The Earl dispatched intelligence of his success to the Parliament. His letter was read to the House of Commons, on the 27th 


\section{CALUMNIES AGAINST THE VICTORS.}

June, giving an account of his taking the town and castle of Oswaldstree, with 400 prisoners and 300 arms. Thanks were voted to him for this his good service, and former testimonies of affection to the house." The circumstantial narrative proceeds to state that "his Lordship returned, after this exploit, to his main army at Drayton," and left Colonel Mytton in defence of the town. The fall of Oswestry was a severe blow to the royal party. Besides opening a door for the reduction of North Wales to the power of the Parliament, it lowered them in the scale of public opinion, a loss, in the declining posture of their affairs, of incalculable importance. Active and energetic as were both Lord Denbigh and Colonel Mytton, in their attack upon Oswestry, still they did not escape the slanders even of their own party. The Earl of Denbigh seems to have felt their calumnies acutely, for a few months after the siege his Lordship wrote a letter to Mytton, vindicating the gallantry of both; which we subjoin :-

"COLL. MITTON,

I will not trouble you with the injuries that are offered to you and myselfe, by the Committe of Wem. I am sure you have deserved more of the Parliament then the rest of that Committe. Captaine Clive, as I am informed, reports I was not at the takeing of Oswaldstre, and that my horse stood att too great a distance; I am sure they entred with the foote ; but the false representations of passages heere shall not divert me from those occasions that may fully expresse me to be

Your faithfull frend and servant,

"Condor, 29th Oct. 1644."

DENBIGH."

At this period the King's position was critical and alarming. In the early part of the month he determined to take refuge within the walls of Shrewsbury, in his march through Worcester and Bewdley. Waller, the parliamentary leader, hearing of Charles's movements, broke up from Oxford, and hastened in the direction of Shropshire. On this intelligence the King left Shrewsbury, and retraced his steps. The battle of Copredy Bridge (June 29th) terminated in the defeat of the parliamentary furces; and in July the Earl of Denbigh, encouraged by his success at Oswestry, drew his forces towards Shrewsbury, but 
was repulsed by the royalist army, with a loss of 120 of his men. The King's defeat at Marston Moor (July 3rd) added, however, to his disasters and dangers. The whole of Shropshire was in arms, and jeopardy and distress stared every man in the face.

Among the prisoners taken in the late disaster at Oswestry was Francis Newport, Esq., who had served both in the short and long Parliaments. The historians of Shrewsbury have furnished us with an interesting account of this distinguished man :- "Mr. Newport was son and heir of Sir Richard Newport, of High Ercall, one of the knights of the shire. This young gentleman was but just eligible to serve in parliament, having arrived at full age only on the 23rd day of the preceding February. He manifested the same ardent loyalty which actuated his father : and ventured, with rare but honourable gallantry, to vote for the acquittal of Lord Strafford, at a time when such votes exposed those who gave them to no small personal hazard; the populace, with their usual toleration of sentiments differing from their own, denouncing all such, fifty-six in number, as Straffordians; and exposing their names to execration and danger by public placards. Mr. Newport was soon expelled from the house as a malignant; appeared in arms against the parliament; and was among the prisoners taken at Oswestry, on the capture of that town by the Earl of Denbigh and Colonel Mytton. It is needless to say that he suffered very considerably in his estate : being obliged to compound in the large sum of $£ 5284$, in addition to $£ 3287$, and $£ 170$ a year extorted from his father for the same crime of loyalty. Yet though attached to the monarchy, he was friendly to the rights of the subject; and it is not a little remarkable, that he who had suffered so deeply for the first Charles, was so much disgusted by the base and arbitary measures of the two succeeding kings, by the last of whom he had the honour of being dismissed from the office of lord lieutenant of this county; that he was a 


\section{COLONEL MARROW'S ASSAULT.}

great promoter of the Revolution, and was excepted, by the abdicated monarch, from his general pardon. He was created earl of Bradford by king William; and died Sept., 1708, in the eighty-ninth year of his age."

The town of Oswestry was now in the hands of the parliament. arians, under the temporary Governorship of Colonel Mytton, but was not long permitted to remain quietly in the power of the victors. Only one short week elapsed before a formidable attempt was made by part of the royalist army, under Colonel Marrow, a skilful and intrepid commander, to retake the town, and drive the parliamentary forces from their position. Colonel Marrow invested the town with 3,500 infantry, and 1,500 cavalry, and maintained a close siege for the three following days. This sudden assault greatly embarrassed Colonel Mytton, whose only hope for relief was from Sir Thomas Myddleton, his kinsman by marriage, who was then stationed at Knutsford, in Cheshire, more than fifty miles distant. Colonel Mytton, however, succeeded in making Sir Thomas acquainted with his position in less than twelve hours from the commencement of the royalist attack; and the gallant knight, who was heartily engaged in the parliamentary cause, immediately mustered three regiments, namely, Booth's, Mainwaring's, and Croxen's, with Major Lothian at the head of the reserve, and marching onwards with all speed, reached in two days within sight of Oswestry - it is supposed between Halston and Whittington. During this interval of time the royalists had not obtained full possession of the town, though consisting, as Sir Thomas Myddleton says, "of the most valiant commanders and soldiers, drawn out of the garrisons of Chester, Cheshire, Shrewsbury, Shropshire, Ludlow, Denbighshire, Flintshire, and other places." They had possessed themselves of the Church, but had made no inroad upon the Castle. Myddleton's approach having been made known, Colonel Marrow marched out from the town, determined to attack him before his troops could recruit themselves 


\section{THE DEFEAT AND PURSUIT.}

after their long march. "They had taken the passage of water neere to Whittington," says Sir Thomas, in his letter to Lenthall, the Speaker, "and very furiously assaulted and charged us, but were repulsed and forced to retire, through the courage of our horse, who most courageously entertained the enemy. Three several times the skirmish was doubtful; either side being forced so often to retreat. But in the end, our foot forces, coming up, relieved the horse, beat back the enemy, and pursued them with such force, that our horse being thereby encouraged, which indeed was formerly weary, joining with the foot, they put the enemy to an absolute flight, in which we pursued them five miles towards Shrewsbury, to a place called 'Felton Heath,' and where we remained after their flight, again masters of the field. In the skirmish with the enemy, and in the pursuite, we lost several of our horse, some of our troopers, but never a footman, which I am yet informed of. As for the enemy they lost several stout men; had many of them taken prisoners, some of them being of great quality, as the Lord Newport's eldest son; and besides, in their flight, such was their haste, that we found in our pursuite the highway as it were strewed with bread, cheese, bacon, and other good provisions ; clothes, and such necessary appurtenances to an army, besides some whole veals and muttons, new killed." Sir Thomas adds, that "his forces followed up their blow nearly to Shrewsbury, and that Majors Manley and Whitney were afterwards taken under the walls of that town, in pursuite of them."

This affair closed the struggle between the royalist and parliamentary forces for the possession of Oswestry. On the very day on which Sir Thomas Myddleton raised the siege, Prince Rupert was signally defeated at Marston Moor, with the loss of ten thousand men killed and taken prisoners. Colonel Mytton must subsequently have delegated his command as temporary Governor of Oswestry, as we find him soon afterwards actively engaged in commanding the parlia- 


\section{AN OFFER OF AID.}

mentary troops in the conquest of Shrewsbury. That event happened early in 1645 , when the town was placed in the hands of the parliamentarians. At this period we find Mytton named, in several public documents, as Major-General in the parliamentary army; and some time afterwards as Commanderin-chief of the forces in North Wales.

All the historical records referring to this period give evidence of the arduous duties of General Mytton, and of the difficulties which he had suffered in maintaining his hold upon Oswestry. A letter which we here give indicates the straits he was in, and at the same time the friendly offers of support made to him in the county. The letter is from a Mr. Edward Mynshull, of Bearstone, near Drayton:-

"Hono ${ }^{\text {ble } t} \mathrm{~S}^{\mathrm{r}}$,

I came to Drayton, hearinge you were there, butt unfortunately mist of you, $\mathrm{yo}^{\mathrm{r}}$ honor lyeinge in Stafforde the night before; I have since then waited $\mathrm{yo}^{\mathrm{r}}$ retorne from London, haveinge 30 able men in readiness, and 20 of them well armed, to doe $\mathrm{yo}^{\mathrm{r}}$ honor servise. I have kepte them together upon my owne charge, and should have bin glad they might have bin accepted in Ossestrie, to doe duty for theire free quarters till $\mathrm{yo}^{\mathrm{r}}$ honor had returned. I motioned this to Major Goldegay, butt itt could nott be granted without an order from the Comitte. Sr, I am resolved to doe you servise, or no man; and for my fidelity, I will engage $£ 400$, paid in Shropshire, and if you please, as much in Cheshire; if yor honor please, I could wish to have a comission sent me by the first, because I only tooke itt in direction from $\mathrm{yo}^{\mathrm{t}}$ honor, and whether thatt may suporte me in $\mathrm{yo}^{\mathrm{r}}$ honor's absence, (should $\mathrm{I}$ be questioned) I make a doubte of. $S \mathrm{~S}$, my request is, I may have order by the first, to martch to Osestree, where I and my men will doe duty for free quarters, (requireinge noe pay) till yo $^{r}$ honor retorneth; and lett me receive order from Major Goldegay to thatt purpose, if you soe please, for were I settled in a garrison, I could have men sufficient. I beseech $\mathrm{yo}^{\mathrm{t}}$ honor retorne me $\mathrm{yo}^{\mathrm{r}}$ pleasure by the first, and I shall willingly embraice yor commands; if yo ${ }^{r}$ honor send to Hugh Bate, Shoemaker, in Wem, he will convey $\mathrm{yo}^{\mathrm{r}}$ letter to $\mathrm{Mr}$. $\mathrm{J}^{\mathrm{m}}$. Grosvenor, in Berson, from whence itt will come safe to me. $\mathbf{S}^{\mathbf{r}}$, I pray for $\mathrm{yo}^{\mathbf{r}}$ honors prosperity and safe retorne, and whilst I live I shall remaine

Att yor servise,

"Berson, April 25th, 1645."

EDWARDE MYNSHULL." 


\section{GOVERNORSHIP OF OSWESTRY.}

The fall of Shrewsbury into the power of the Parliament was marked by "a solemn thanksgiving throughout the City of London," on the 12th March ; Mytton was summoned to appear before the House of Commons on the 29th of that month, and "Master Speaker, in the name, and by the command of the whole House, gave him hearty thanks for his many and faithfull services done to the state; giving him all encouragement to persist in the same: especially for that gallant service of Shrewsbury; assuring him that he shall never want the encouragement of the House of Parliament in his undertakings."

General Mytton had evidently embarked all his energies in the parliamentary cause ; yet notwithstanding the tribute paid to him by the Commons, it does not appear that he obtained from that source any more substantial honours. This neglect seems to have given him much pain. A letter to him from the Duke of Northumberland, about this period, shews that even the Governorship of Oswestry was not actually accorded to him till late in the year 1645. The letter we subjoin :-

" $\mathrm{Sr}$,

By an indisposition in my health, I have not beene able for some dayes to attend the Committie of both kingdomes, so as I can not give you so good an account of your businesse as I desired, but I heare that a commission for your being governor of Oswallds-tree is alreadie signed; to-morrow I shall make a further enquirie after this particular, and if it be in my power to contribute any thing towards your satisfaction, none shall more readily assist you then

Your very affectionate freind and servant,

"London, Nov. 21, 1645."

NORTHUMBERLAND."

"For my very loveing Freind, Col. Mytton."

The conquest of Shrewsbury, by the parliamentary troops, is generally acknowledged to have been achieved by the gallantry and superior tactics of General Mytton; and having 
accomplished so signal a service for his party, he naturally expected, now that the Governorship of that town was vacant, that the office would be conferred upon him. His ancient relation to the town, his ancestors having been inhabitants and burgesses for upwards of four centuries, added strength to his claim. All his important services to the Parliament were, however, of no weight, and the Governorship was bestowed upon another man. We are told that "Colonel Mytton's politics were getting very fast out of fashion. He had sided with the Parliament only for the limitation of prerogative, not for the subversion of the monarchy. The Presbyterians, to whom, it appears, he belonged, had no insurmountable objections to the office of a king, provided he was under their controul: or to a national establishment of religion, if its revenues were at their disposal. But those who commence important changes in a state have seldom the satisfaction of reaping the fruit of their labours. Spirits more ardent, with views more extensive, step in between them and. the consummation of their designs." With Sir William Waller, another of the ablest and most successful commanders of the Presbyterian party, he could say, "after the expence of so much blood and treasure, all the difference between our former and present estate is this, that before-time, under the complaint of a slavery we lived like freemen; and now, under the notion of a freedom, we live like slaves, enforced by continual taxes and oppressions, to maintain and feed on our miseries."

Although General Mytton had been thus ungratefully treated by the Parliament, he still occupied his military position, for we find that in 1648 he was engaged with Sir Thomas Myddleton in the attack upon Caernarvonshire and Anglesey. In June of that year the Speaker of the House of Commons communicated to him a letter, highly approving his "good and faithfull service" against "Sir John Owen and his rebellious crewe." The letter referred to is a curiosity, as it 
shows the blasphemous freedom which Cromwell's parliament took with the holy name of GoD :-

"Sir,

I received a letter súbscribed by yourself and the Governor of Conway, wherein you gave an account of the late successe wherewith God hath beene pleased to blesse the forces under both yor commands and coniductes in $\mathrm{yo}^{\mathrm{r}}$ late expedition into Carnarvonshire, against Sir John Owen and his rebellious crewe, $w^{\text {ch }} \mathrm{I}$ have imparted to the house, and hath beene there read. $Y_{0}{ }^{r}$ good and faithfull service in that expedition is soe well represented, that $I$ am comanded, as from the house and in their name, to returne thanks for the same, $w^{\text {ch }}$ hereby I doe, and you are desired to do the like to those officers and souldiers under the charge and comand $w^{\text {ch }}$ God hath beene pleased to make instrumentall in the obteyning of such a seasonable mercy, and withall to represent to the house what course (like to be effectual) may bee taken for remunerating ye officers and souldiers for their good service. This beeing all $I$ have in comand at present, I shall only add that I am

$Y \mathrm{O}^{\mathrm{r}}$ assured loveing freind,

"June the 13th, 1648."

WM. LENTTHALL, SPEAKER."

Lenthall, the Speaker, was profuse, as we have shewn, in compliments, but still no substantial mark of favour upon General Mytton was bestowed. The Committee to whom the appointment of Governor of Shrewsbury Castle had been referred had long before found "reasons of weight to put another" in that office, after having held it in their own hands for some time. In 1647 the Governorship was filled by Humphrey Mackworth, Esq., of Betton, a Presbyterian, and Colonel in the army, who occupied the post till his death, in 1654, and having been one of Cromwell's Privy Council, was buried in Henry VII.'s Chapel in Westminster Abbey, on the 26th December, with great magnificence. He was succeeded in office at Shrewsbury by Thomas Hunt, Esq., representative of the town in Parliament, and a Colonel in the army. Mytton retired to London, from what immediate cause there is no record to show; but some writers assert that he resigned his command. In 1651 we find that the Parliament again solicited Major-General Mytton's services, the following 


\section{DEATH OF GENERAL MYTTON.}

letter having been forwarded to him by the President Bradshawe. The kingdom was disturbed at this period by the Scottish Covenanters, under the nominal command of Charles II. :-

$$
\text { " } \mathrm{S} r \text {, }
$$

The Scotts army being now entred into England, and bending their course towards those parts where wee know you have a good interest, wee conceive your presence there may bee of use for the service of the Commonwealth; wee therefore desire you forthwith to repaire into the Countie of Salop, and there, with the rest of your fellow Commissioners, doe your best endeavour, and put out your interest there for the raiseing of what force of horse and foot you can, for the service of the Commonwealth in this present exigency of affaires.

Signed in the name and by order of the Councell of State, appointed by authority of Parliament,

"Whitehall, 14th August, 1651." JO : BRADSHAWE, Prsidt." "For Major General Thomas Mytton."

Most probably by this time General Mytton had grown tired with the hard toils of intestine warfare, and become disgusted with the faithlessness of the men whom he had so ardently and faithfully served; for we do not find that he complied with Bradshawe's letter, or took any further part in public affairs. He died in the metropolis in the year 1656, and his body was takeri down to Shrewsbury, and interred in St. Chad's Church there.

\section{THE RESTORATION.}

It is unnecessary here to do more than merely advert to the unhappy close of Charles I.'s reign, the triumphs of Cromwell, and the bold and manly efforts made by Charles II. to obtain the Crown which had been so violently wrested from his father. Although Cromwell had made himself Lord Protector of England, Scotland, and Ireland, yet he reposed not on a bed of roses. "Every party in the kingdom soon became disgusted with Cromwell's dominion. The royalists were indignant to see the ancient monarchy usurped by an upstart who had no hereditary claim upon their allegiance; 


\section{THE RESTORATION.}

the republicans were mortified to see all their blood and efforts, which had been spent for the setting-up of the Commonwealth, lavished only for the support of a government which, in everything but the name, was a most despotic monarchy; the Presbyterians were chagrined at the favour of their rivals, the Independents, and at a general toleration of every religious denomination (except the Church of England)." Conspiracies and plots were hatched in many parts of the land; and the Protector was kept on the alert by daily intelligence that the exiled king would challenge the usurper, and claim the British throne as soon as a favourable opportunity presented itself for so bold an enterprise. Cromwell, however, after various struggles with the royalist forces, was summoned to "the house appointed for all men living." He was succeeded, for a brief period, by his son Richard, who speedily retired from public life. General Monk, who had been an intrepid commander both of the royalist and the parliamentary forces, and who possessed powerful influence in the country, on the death of the Protector Cromwell wisely threw the weight of that influence into the royalist scale, and adopted measures at once to bring back Charles II. from France to England. Upon that joyful event all ranks hastened to return to their allegiance, and on the 29th of May, 1660, Charles II. set his foot again upon British soil, and immediately assumed the functions of sovereignty.

During the events to which we have been adverting the town of Oswestry suffered much privation and distress by the feuds and divisions into which all classes of men were thrown. A letter from Mr. John Griffith to Major-General Mytton, dated January 7 th, 1650, shows that Oswestry was enduring much hardship. The letter, which is copied from the Halston MSS., is as follows :-

"Honor'd Sir,

I receaved a note from

to write unto $\mathrm{yo}^{\mathrm{r}}$ honor concerning our sufferings. I presume yo ${ }^{\mathrm{r}}$ honor 


\section{SIR THOMAS MYDDLETON.}

knowes the maner of our sufferings, and how we may be releeved is better known to you then to us. The Baylifes and the rest of the sufferinge people of Oswestree depende much upon your assistance, and hope yo ${ }^{\mathrm{r}}$ honor will have a fitt opportunity to doe this poor towne good.

I shall make bould to put yo honor in mind of your promise to draw a petition to the Parliament wth $\mathrm{yo}^{\mathrm{r}}$ owne handes, $\mathrm{w}^{\text {ch }}$ we all hope you will doe before $\mathrm{yo}^{\mathrm{r}}$ returne, and then $\mathrm{yo}^{\mathrm{r}}$ honor shall further ingadge the whole towne ever to pray for $\mathrm{yo}^{\mathrm{r}}$ honor, and especially

Yor servant,

"Osw., the 7th of January, 1650."

JOHN GRIFFITH."

"To the Honrable Major Generall Mytton, at London."

There are no records extant showing precisely the position of civil and military affairs, as regards the town of Oswestry, in the struggles of Charles II. for the Crown. The parliamentary party held firm possession of all towns which they had taken, and against Charles they fought as fiercely as against his murdered father. Whatsoever the position of Oswestry was at the period to which we are referring, that of a valiant neighbour, Sir Thomas Myddleton, of Chirk Castle, was dangerous and deeply painful. In 1659, upon the royalists of Cheshire, headed by Sir George Booth, declaring in favour of Charles, the venerable old man, then eighty years of age, decided in favour of the ancient constitution, believing monarchy to be indispensable to the settlement of the nation, and proclaimed Charles II. at Wrexham. For this act he suffered severely, but was named afterwards as Commanderin-chief of the Counties of North Wales, and as Governor of Shrewsbury, although this latter nomination seems to have embarrassed Sir Edward Hyde, Chief Minister of Charles II., as likely to clash with the views of his friend Lord Newport, who had ever been a staunch friend to the royalist cause.

The events of public interest that occurred in connection with the town subsequent to the Restoration were "few and far between." The most important act in Charles II.'s reign was his grant in 1673 of a Charter, which, looking at 


\section{CHARTER OF CHARLES II.}

the privileges it confers upon the town, is considered by some to be the Magna Charta of Oswestry. Its importance to the borough, as its provisions are still acted upon in the leading Law-Court of the town, justifies us in giving a correct abridgment of it:-

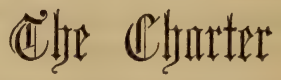

was granted "to the ancient Borough and Corporation of Oswestry, alias Oswaldstrey, in the County of Salop: That they be encorporated by the name of The Mayor, Aldermen, Common-council-men, and BuRgesses of Oswestry ; and that they are empowered to purchase lands to them and their heirs for ever, and to give and bequeath or otherwise dispose of the same: That the said corporation may have one common seal for dispatching of all business concerning the said borough; and to change and make new their same seal, as often as they shall think convenient: That there be Twelve Aldermen and Fifteen Common-council-men; whereof one of the said aldermen is to be Steward: and that whoever is chosen steward, must come in as an alderman. And that there shall be chosen a discreet person for Recorder, well learned in the law, who must be one of the Common-council-men: That the said borough may have one house of meeting, to be called the Guild-hall of the said town; and that the mayor, aldermen, common-council-men, steward, and recorder may meet there, or in any other convenient place within the said borough, for making, establishing, \&c. any laws, orders, \&c. for the better government of the said corporation: and to declare in what manner the said mayor, \&c. may manage themselves in the negociation of the said borough: and that the said mayor, aldermen, \&c. or the greatest part of them, may imprison the bodies or impose fines or otherwise, upon all such as shall offend against the said laws, \&c. and that the one moiety of the said fines to be levied for the use of the said mayor, aldermen, \&c.; and the other moiety to the use of the lord of the manor: provided, such laws, \&c. be not repugnant to the laws of the land, or contrary thereto, or prejudicial to the lord of the manor: That Richard Pope, first mayor, continue in his mayoralty from the day of the date hereof, until the next Friday after the feast of St. Michael, the Archangel, 1674, and until another be sworn in his stead. Sir John Trevor, knt.; Morgan Wynne, esquire; Edward Owen, Richard Edwards, Richard Lloyd, the aforesaid Richard Pope, gentlemen; Gabriel Edwards, woollen-draper; Hugh Price, woollen-draper; John Jones, mercer; Richard Jones, John Blodwell, gentlemen; and John Lloyd, mercer, to be the first aldermen: and to continue in their office during life, unless for just cause any of them shall be removed by the mayor, aldermen, common-council-men, $\&$ c. or the 


\section{THE CHARTER.}

greatest part of them.-Richard Price, brewer; Richard Jones, mercer; John Glover, tanner; Richard Jones, glover; Edwd. Evans, apothecary ; John Jones, glover; John Muckleston, shoemaker; Thomas Edwards, gentleman; Thomas Edwards, baker; Nathaniel Jones, brewer; Hugh Edwards, shoemaker; Timothy George, mercer; Thomas Vaughan, chandler; William Price, butcher; and Thomas Felton, brasier, to be the first common-council-men; and to continue in office during life, unless removed as aforesaid. The mayor, \&c. to meet on the next Friday after Michaelmas, yearly, and to choose at that time, out of the common-council-men, a new mayor; and to swear him in then, if present, or within twenty-one days next after such election, before the old mayor or (in his absence) before two or more of the aldermen of the said borough. If the mayor happen to die, or be removed out of his place for not well demeaning himself, or for any other just cause, before the expiration of the said year, that then and in such case, the aldermen, and common-council-men, \&c. or the major part of them, shall elect and choose another mayor for the executing the said office of mayoralty during the remainder only of the said year. And upon the decease of any aldermen or common-council-men, to choose others to make up the number; administering to them their oaths for the executing of their places : and that they shall be sworn in the presence of the mayor, or (in case of his absence) of the aldermen, common-council-men, or the major part of them. In case the mayor be sick or absent, that the mayor may constitute and appoint one of the aldermen to be his deputy ; and that being duly sworn, he may officiate the place of mayoralty during such sickness or absence, as fully and effectually in every respect as the said mayor might or could have done personally. When Morgan Wynne, the present Recorder, dies, or should happen to be dismissed, that the mayor, aldermen, \&c., choose another, able and experienced in the law, within one month after such decease or dismission. The mayor, coroner, steward and recorder, during the time and term of holding their places, shall be Justices of the Peace, \&c., and that each and every of them are Clerks of the Market, to settle weights and measures, and all other laws and ordinances incident thereto; and to officiate the same as fully and effectually as any other of his Majesty's justices of the peace might or could do. Sir John Trevor, knight; Robert Owen, and Edward Kinaston, esquires, or any of them, to swear the first mayor ; and that the mayor being sworn, he is to swear the coroner, steward, recorder, \&c. That the mayor, steward, and recorder, or any two of them (whereof the mayor to be one) may keep a Quarter Sessions for all offences, as fully and effectually as the justices of the said county of Salop may do ; and that any one of them may commit to the common gaol of the said county any person accused of treason, murder, man-slaughter, or felony, whatsoever: and that the justices of the said county have no power to intermeddle with the said borough upon any cause whatsoever. That the 
mayor (for the time being). shall choose any inhabitants of the borough, Constables; and to swear them in accordingly. The mayor to choose two Sergeants, to attend upon him or his deputy, when required; and to continue for one year (if they well demean themselves): and that the said sergeants shall carry two maces with his Majesty's and successors' arms, and the arms of the lord of the manor thereon, in their hands or upon their shoulders bare-headed, before the mayor, when required: and that the said sergeants shall be sworn by the mayor, for the due executing of all precepts, warrants, \&c. The last mayor to be Coroner, who shall have as full power to officiate as any other coroner in any of his Majesty's counties hath, or may have; and not to execute his power before he besworn before the mayor or his deputy: and upon the death of any coroner, the mayor, aldermen, \&c., to choose another. A Court of Record to be kept every Friday, at the guild-hall, before the mayor or his deputy; and to try all actions and causes whatsoever, as fully as the bailiffs and burgesses formerly did, or as fully as any corporation in his Majesty's kingdom do, or did formerly: and that the mayor, \&c. shall have to their use the one moiety of the issues, amerciaments, \&c. ; and the other moiety thereof, to the use of the lord of the manor. John Morral to be Common Clerk of the Borough, and Clerk of the Court ; and may have a deputy, to be appointed by the steward: that the common clerk to be nominated by the lord of the manor, and to be sworn, as well as all other officers by the mayor: that if he shall not reside in the said borough, then he shall employ, in his absence, an honest and able attorney of the said court, to be approved of by the steward : and the said attorney shall officiate in the time of his absence. - Six Attornies to be of the court: whereof four to be chosen by the mayor, and two by the steward. One Marshal, or Crier to be chosen by the mayor. The mayor, aldermen, \&c. to have within the borough a Gaol or Prison, for detaining of all prisoners, committed by the mayor, steward, or recorder, or any of them: and that the mayor, recorder, clerk of the market, common clerk, marshal, keepers of the prison, and sergeants (for the time being) shall receive such Fees, \&c. as the bailiffs, \&c. of Ludlow, and the said borough, have hitherto received. [Ludlow fees are half of the Common Pleas.] All burgesses and other inhabitants of the said borough to pay scot and lot, and to be assessed for the maintenance, good order, and further profit of the same; and in default of payment, distresses to be laid upon their goods.-The mayor, \&c. to have power to elect persons who have served seven years' apprenticeship, or that have been householders (paying scot and lot) seven years within the said borough, Burgesses : and with the approbation of the steward, to make any other person burgess of the said borough; and so continue, unless for any just cause he be expelled by the mayor, \&c. No Stranger or Foreigner shall exercise any Trade in the borough (except it be in time of fair) unless he be a burgess ; nor keep any shop, without special licence from the mayor, 


\section{THE CHARTER.}

aldermen, \&c. or the major part of them: the mayor, \&c. to punish such foreigners and strangers by fines, and to distress upon their goods, in default of payment. The mayor and.corporation, and burgesses, Exempt from serving on Juries out of the borough, at assizes or quarter-sessions. The corporation to have return of writs; and all which returns to be made by the mayor. No high-sheriff, or any of his officers, to enter the liberty, unless in defect of the mayor for the time being. The mayor or clerk to receive recognizances, according to form of Statute Merchant, or Acton Burnell; and to make execution, \&c. as fully as any other town can do, by virtue of the said statute: and that there shall be a seal for the sealing of those recognizances. The mayor and corporation may purchase lands, \&c. not exceeding $£ 50$ a year, but such as are not held in capite or knight's service. The said borough is to enjoy two Markets weekly, for ever; that is, one on Wednesday and the other on Friday. To have a Fair on the 2nd, 3rd, and 4th days of March, yearly; and the fairs on the 1st and 2nd of May, the 4 th and 5th of August, and the 29th and 30th of November, to be continued as heretofore. And if any of the said fairs shall fall upon the Lord's-day, then the same to be kept on the Monday following. The mayor, \&c. may hold a Court of Pie-poudre at the time of the fairs; and to take the usual tolls of markets and fairs-all rights, \&rc. of the lord of the manor excepted.

The privileges secured to the inhabitants of the borough by this Charter must, at the time of its being granted, have been very valuable, and no doubt contributed greatly to the good government and prosperity of the town, during subsequent times. Some of such privileges have been superseded by the provisions of the Municipal Corporation Act, 5 \& 6, William 4th, cap. 76, entituled "An Act to provide for the Regulation of Municipal Corporations in England and Wales," and other modern enactments ; but others still remain, although the value and convenience of them appear in some degree to be overlooked. The Charter secures some peculiar privileges with respect to trade which may not probably harmonize with modern views and notions; but the privileges, of trying at Quarter Sessions all offences, except felonies, committed within the borough, and of suing for debts, unlimited in amount, in the Court of Record, ought not to be regarded otherwise than as precious relics of byegone times. It is true, that the Court of Quarter 


\section{THE CHARTER.}

Sessions has been constantly and regularly held by the most able Recorder, J. R. Kenyon, Esq.; but the Court of Record has of late years been so seldom ressorted to, that on a late occasion, when a cause was tried before it, a local newspaper referred to it with special wonder, hinting its surprise that, in a place where the weapons of legal warfare were so easily obtained, the inhabitants should so long have ceased to use them, and to remain in peace amongst themselves, without any legal strife in a Court of Record. Although, however, debts without limit, as regards amount, may be sued for, the final process of the Court is confined to the borough, and cannot be put in force beyond its boundary; and this circumstance, connected also with the facilities for the recovery of debts afforded by the Small Debts Act, has rendered resort to the Court of Record less frequent than, under other circumstances, it doubtless would have been; still, to have it is a privilege, as is also the exemption from serving on Juries at the Assizes, or County Quarter Sessions, secured by the Charter.

The Restoration brought with it, of course, the ascendancy of loyal subjects and monarchical principles in all parts of the realm. Charles, however, did not make the wisest use of the power and influence he had newly acquired; and the closing hours of his life proved that his religious principles, unfixed and vacillating, were ill adapted to the requirements of the age. Howsoever much other parts of the kingdom were disturbed during this reign, the town of Oswestry would seem to have resumed a tranquil position: the injury and damage sustained in it during the many years of disquietude and war were partially restored; the ancient Church was gradually repaired; but the Castle, so dilapidated and broken down, was permitted to lie in ruins; the crown made no effort to restore it; and by degrees its shattered walls and fallen columns were carried away by nocturnal depredators, until at length the vestiges of the fortress consisted of little more than the mound still left in our sight. 


\section{BISHOP LLOYD.}

In 1681 , only four years before Charles's death, a polemic scene was enacted in Oswestry, which, from the celebrity of the parties engaged in it, forms no uninteresting feature in the history of the town. Charles's reign was marked by odious political intolerance and injustice. He aimed at absolutism, and was as regardless of religious liberty as of religion itself. The controversy to which we have alluded occurred in the Guildhall of Oswestry, in September, 1681, and was conducted throughout in a spirit of candour and moderation not frequently to be witnessed in that turbulent period. The leading parties engaged were Dr. Lloyd, Bishop of St. Asaph (the prelate who preached the first sermon in the Chapel Royal to William III.), and the distinguished Philip Henry, of Broad Oak, Flintshire (father of the erudite and evangelical Matthew Henry, the Commentator on the Bible). Other nonconformist Ministers were present, and took part in the proceedings, especially Mr. James Owen, then of Oswestrybut afterwards of Shrewsbury Seminary for the education of Dissenting Ministers-a man of considerable acquirements and genuine piety. The Bishop, upon his elevation to the episcopal chair, was desirous of securing the conformity of those who dissented, and "that he might do it with the cords of a man, he resolved to reason the matter with them, and endeavour to effect their conviction by discourse, in which he had a very great facility both by learning and temper." The account from which we derive these particulars goes on to state, that "one of the most eminent nonconformist ministers in his diocese was Mr. James Owen, of Oswestry. The Bishop had several interviews with $\mathrm{Mr}$. Owen in private. At last he appointed a meeting to be held in the Town Hail, Oswestry, on Tuesday, the 27th of September, 1681, at which , he requested $\mathrm{Mr}$. Owen to give an account 'by what right he exercised the ministry, not having episcopal ordination.' $\mathrm{He}$ also directed him to procure any other ministers he could to assist him, for 'he would be glad to hear what any of them had to say for themselves.' Mr. Owen sought the co83 


\section{POLEMIC DISCUSSION.}

operation of Mr. Henry, which, after much hesitation, was granted; to whom also was joined Mr. Jonathan Roberts, 'a plain man of great integrity, and a very good scholar.' On the day appointed the Bishop made his appearance with the famous Henry Dodwell. 'In those days of intolerance, some parties had refrained from engaging in the controversy, 'lest it might be prejudicial to their liberty. The Bishop, however, was pleased to promise that no thing which should be said, by way of argument, should be any way turned to the prejudice of the disputants, nor advantage taken of it to give them trouble.' There was convened a large number of the gentry and clergy of the neighbourhood, the magistrates of the town, and a great concourse of people. The discussion lasted from two in the afternoon till between seven and eight at night. 'Much was said, pro and con, touching the identity of bishops and presbyters, the bishoping and unbishoping of Timothy and Titus, \&c. It was managed with a great deal of liberty, and not under the strict laws of disputation.' 'The Bishop won golden opinions from all parties on account of the gravity, calmness, and evenness of spirit' with which he conducted his part; while he seems to have been so much gratified with the temper of his opponents, as to have formed from that time a most intimate friendship with Mr. Henry." The report does not inform us whether the Bishop was convinced by the arguments of the nonconformists. That Philip Henry retained his opinions is undeniable; for he never ceased advocating, with Christian zeal and moderation, the principles of nonconformity. It is gratifying, however, to read of so tolerant and well-conducted a disputation in so persecuting an age; it speaks much in favor of the just and beneficent spirit of Bishop Lloyd.

The reign of James II. offers no particular incident in relation to Oswestry. As a sovereign he was worthless and dangerous. His darling objects were, the establishment, throughout the land, of the Roman Catholic religion, and the restriction of popular freedom. During his brief occupation 


\section{A MAYOR'S BLUNDER.}

of the throne he paid a visit to Shrewsbury and Whitchurch; and on his way from the metropolis sojourned at Ludlow for a night, and passed through the Strettons. The people of Shrewsbury had not been favoured with a royal visit for nearly half a century, and were now disposed to give the monarch a cordial reception. All the public functionaries were trained and disciplined as to duty, for an incident had occurred in the royal progress, so ludicrous in character, that the Shrewsbury corporation resolved it should not be reenacted amid their loyal congratulations. The story to which we refer may be true or fabulous; but it is too good not to be connected with a notice of James's reign: and, after all, the mayor of the town where the scene is laid, in adopting literally the promptings of the learned recorder, was not, to use a common phrase, "so great a fool as he seemed to be." If King James had received those promptings in a wise spiritmirth-exciting as they must have been-he might have been a good sovereign, and had around him loyal and devoted. subjects.

The mayor whose absurdities we are about to describe is said to have been both illiterate and dull, incapable of reading or remembering an address. It was settled therefore, says the tale, that the recorder should stand behind him, to set him right if he happened to be out. When they (the corporation) were ushered into the royal presence, and the chief magistrate was about to commence his harangue, as he appeared somewhat sheepish and embarassed, his friend! y monitor whispered in his ear, "Hold up your head, sir, and Lok like a man!" Mistaking this for the beginning of his speech, he boldly stared the king in the face, and roared out, "Hold up your head, sir, and look like a man!" Alarmed at the frightful blunder just made, the recorder whispered to the chief magistrate (who at this moment must have resembled the celebrated Mayor of Garrat, with two nosegays in his coat), "What the d-l do you mean, sir?" The mayor, as stolid as ever, and 


\section{THE REVOLUTION.}

nothing abashed, thundered out the recorder's exclamation as boldly as before. The recorder, indignant and irritated, muttered, "By heavens, sir, you'll ruin us all!" His worship, taking this to be a continuance of the speech, and still staring his majesty full in the face, with a yet louder voice repeated, "By heavens, sir, you'll ruin us all!" Even kingly patience could bear this no longer, and rising, his majesty in an angry tone demanded what was the meaning of this jargon? when the recorder laid before him "the facts of the case," and the king passed the affair by with a gracious smile.

\section{THE REVOLUTION.}

The Revolution of 1688 brought over to England William III.; and his reign was followed by that of "good Queen Anne." Her reign has been termed the Augustan era of English literature, as it was graced with the polished writings of Sir Isaac Newton, Addison, Steele, Farquar (who laid the scene of his comedy, "The Recruiling Officer," in Shrewsbury, and who, in his epistle dedicatory, first used the lively sentiment, "To all friends round the Wrekin," now one of the social laws of Salop), of Vanbrugh, Prior, Pope, Parnell, Garth, Gay, cum multis aliis. Instructed as the nation was by these and other eminent men, still bigotry and enthusiasm were evidenced by many in matters of religion and politics. In the year 1709 the nation was thrown into a gentle ferment by the indiscreet conduct of the government towards an obscure clergyman named Sacheverell (who had long been starving on a poor curacy in London), in consequence of his having preached and published two scurrilous and intemperate sermons, of which red-hot politics were the staple. He was summoned to the bar of the House of Lords, and impeached. The Whig ministry viewed his attacks with alarm and he was sentenced not to preach for three years. This persecution, as the proqeedings of the government were called at once martyrised Sacheverell, who suddenly found himself famous. "A entleman residing in the neighbourhood of Oswestry, Robert 


\section{DR. SACHEVERELL.}

Lloyd, Esq., of Aston, sympathized with the suffering Sacheverell, and . became his friend. Mr. Lloyd had been the doctor's pupil at Magdalen College, Oxford; and as the rectory of Sylattyn, in his gift, became vacant at this juncture, he presented it to the high-church meteor. This was doubtless a god-send to the doctor, who set off from London, to take possession of his new living, with all the state which a corrupt popularity could give to him. A Tory writer of Queen Anne's reign tells us that "he entered upon his triumphant progress to Shropshire. He was magnificently entertained at Oxford by the University, and received in the other great towns he passed through (Shrewsbury and Oswestry included) with the loud acclamations and joyful congratulations of the people, upon his deliverance from whig persecution." In Shrewsbury the crier was sent about to proclaim his arrival, and the bells were rung in honour of the event. As he passed through Oswestry, it is related, the crowd assembled to witness his arrival was so great, that an enthusiastic old woman, a great dabbler in politics and religion, no doubt, was so excited in her endeavours to obtain a sight of the distinguished bigot, that she succeeded only in catching a passing glance at his figure and periwig. "I could see only part of the holy man," she exclaimed, "but I console myself with having had a sight of his ever-blessed wig as he rode along." This sort of mummery was not confined to Oswestry. In many towns people were desirous to have their new-born infants christened with a name so revered; which, having been transmitted through succeeding generations, is not yet extinct in this county. On his return to London he met with nothing but laudations, except at Worcester, where, by the direction of Bishop Lloyd, a suitable rebuff was administered to him. Of Dr. Sacheverell nothing more was heard worthy of transcription. Like most other men whose popularity is created by intolerant doctrines in religion or politics, he speedily found that his sudden greatness was as mutable as it was undeserved. 
The death of Queen Anne, in 1714, secured to the kingdom the Brunswick Dynasty. The Act of Settlement, passed in the reign of William III., provided that the crown of Great Britain should henceforth be held only by Protestant Princes. James Stuart, Queen Anne's brother, known more popularly as the Pretender, could not reign in England because he was a Roman Catholic, and George, Duke of Brunswick, and Elector of Hanover, a Protestant Prince, whose mother was grand-daughter of James I., became King of Great Britain. The Brunswick succession has continued till the present time, the united kingdom deriving especial benefits from the reigns of the three Georges, of William IV., and of Queen Victoria. Under the sway of George III. enlarged freedom, civil and religious, was extended to his subjects; arts, science, and commerce flourished, and the people made rapid advancement in religious and moral improvement. The memorable wish of the venerable monarch George III., "That every one of his subjects should read and possess the Bible"-a far more generous sentiment than that of the French King who desired to see the day when every one of his subjects should be able to put a fowl into the pot once a week-was largely realized through the instrumentality of Robert Raikes, Dr. Bell, and Joseph Lancaster, the great promoters of education in the land, and by, also, the foundation of the British and Foreign Bible Society, whose distribution of the Scriptures gave an impulse to religious and benevolent efforts which have been increasing in usefulness and efficiency to the present day. Under the auspices of George IV. the nation derived numerous blessings, deficient as he was of many of the bright qualities that ought to shine in the moral diadem of a British King. The reign of William IV. - the Sailor King, as he has been familiarly but appropriately called-was rendered illustrious by his intense regard for the interests of the people, and his sanction to the second Great Charter of British rights. Under the mild and gracious rule of our beloved Sovereign Quenen Victoria, tlie rights and privileges of Britons are Lield sacred; literature, arts, and science have acquired "a \&8 


\section{A GLORIOUS AGE.}

more than double sway;" commerce and manufactures, in a multiplicity of forms, for the comfort and luxury of mankind, have careered onwards with giant steps, that have astonished and delighted the wisest and the best ; the social comforts of all classes of the British community are rendered almost boundless by the progress of invention, the ingenuity of mechanical skill, and the unceasing activity of all industrial pursuits; the unrighteous laws that prohibited the importation of corn have been abolished; free trade in bread has been established with all the nations of the earth; ancient grinding monopolies have been destroyed; national imposts reduced; the just demands of the people speedily granted; harsh feudal laws, carrying with them inhuman punishments, have been blotted out of the Statute-book ; "man's inhumanity to man," under the sanction of Acts of Parliament, has been softened if not wholly subdued; the just principle of national brotherhood, inculcated by divine precept, has gained vital force; religion has become less sectarian, and more thoroughly Christian in profession and practice; the helping hand of man to his brother man, in the hour of necessity, is seen now more actively at work than ever; the people at large are united as one man, in all great designs of philanthropy and benevolence, and in all puissant combinations against injustice and oppression; our QueEN and her enlightened and virtuous Consont are ever watchful for the country's weal. The reign of VICTORIA is thus far the brightest page of regal history, because it has been pre-eminently the best. We may sum up in the eloquent language of Dr. Southwood Smith:"We live in a glorious age. The rapidity of the progress of liberal opinion, and I will add, of liberal feeling, within these few years has been unexampled in the history of our race. Sometimes indeed the tide of improvement like the tide of the ocean may appear to have receded; but soon, as if deriving strength from its momentary retreat, slow, majestic, irresistible, it has rolled beyond its former limit; but, unlike its type, it has not returned, $a^{r}$ i it will not return, to the boundary it has passed." 


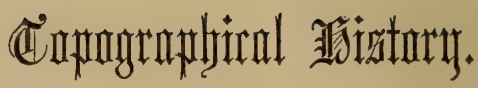

I

SWESTRY is one of the most interesting of the English Border towns, as we have already endeavoured to show; its early history, in various conflicting ages, being crowded with incidents to give to it a lasting renown. In its present state it offers numerous claims to public attention; and the time does not seem far distant when it will take its rank among the more flourishing towns of the empire. Having railway communication direct with the metropolis, the great seats of manufacturing industry in the northern counties, and by a new line of conveyance, both of passengers and goods, via the rapidly-rising town and port of Birkenhead, with the sister kingdom, its importance and improvement will quickly increase. Nor is the contemplated railway extension from Oswestry to Welshpool and Newtown to be overlooked, as that may soon lead to the still further construction of a railway forming a junction with the projected line from the latter place to the busy town of Llanidloes, and stretching onward till it reaches the great harbour in course of formation at Milford Haven. With such "means and appliances" the trade and commerce of Oswestry are not likely to retrograde; and although we possess not the poetical and sanguine temperament of Griffith of Glyn Ceiriog, who, some centuries ago, fancied that "in merchandise it resembled Cheapside," in London, yet we have no doubt that Oswestry, which is now prospering commercially, and diffusing much good, both morally and religiously, will advance steadily forward in the 90 
march of general and social improvement. We are too gallant not heartily to concur on another point with the Welsh poet just quoted. In his days, he says, "The handsomest women, and the most becomingly drest, are those of Oswestry." If we did not unhesitatingly applaud this opinion of a Welshman, we should consider ourselves unworthy the name of Englishmen!

The site of Oswestry is remarkable. It stands upon more elevated ground than any other town in Shropshire, being 450 feet above the level of the sea. Its commanding position freely exposes to the gaze of the delighted spectator a range of landscape scenery which, for variety, beauty, and grandeur, cannot be excelled in any part of the kingdom. On the heights above the town the prospect expands. To the southeast the fertile vale of Salop displays its diversified charms, the Nesscliff Rock, Hawkstone (Lord Hill's beautiful ancestral residence), and the huge and venerable Wrekin peering forth in the distance; whilst the high ridges of the Longmynd and Stiperstones form an uninterrupted chain along the Welsh border, with the bold and abrupt acclivities of Cefn-y-Castell and Moel-y-Golfa; and the Breidden, crowned with Rodney's Pillar, completes the great natural panorama. Towards the east the Macclesfield hills, dividing Cheshire from Derbyshire, appear. The view on the Welsh side is equally impressive, and may well be called "the paradise of Cambria."

The fullest topographical description of ancient Oswestry that we have discovered is that of Harrison, who wrote in 1564. He says, "Oswester is eighteen miles from Shrewsburie, and containeth a mile within the walls. It hath in like sort foure suburbs or great streets, of which one is called Stratlan, another Wuliho, the third Beterich, wherein are one hundred and forty barns, standing in a row, belonging to the citizens or burgesses, and the fourth named the Black Gatestreet, in which are thirtie barns maintained for corne and haie. There is also a brooke running thorough the town by 91 
the crosse, coming from Simon's well, a bowshot without the wall, and going under the same, between Thorow-gate and New-gate, running under the Black-gate. There is another, over whose course the Baderikes or Baderich-gate standeth, and therefore called Baderich brooke; the third passeth by Willi-gate or New.gate, and these all fall, together with the Crosse brooke, a mile lower by south, into the Mordaunt." Leland, the historian, who briefly sojourned in the town in the reign of Henry VIII., informs us that the northern part, or Beatrice-street, at that period contained "many barns for corn and hay, to the number of vii score several barns;" the eastern, or Black-gate, " $\mathrm{xxx}$ barns for corn, with other houses "]onging to the townesmen." The same writer adds, "There be within the town iii most notable streates, the Cross-streate, the Bayly-streate, and New-gate-streate. The houses withyn the town be of timbre, and slated. There is a castell, sette on a mont be likelihood made by hand; and ditched by south-west, betwixt Beatrise-gate and Willow-gate, to the which the wall comith. There be no towers in the waulles besides the gates. The town is dicked about, and brokettes ren ynto it." Camden describes Oswestry in his day as "a place of good traffic, inclosed with a wall and ditch, and fortified with a castle." Pennant's brief description brings us nearer to the present time. "Oswestry," he says, "stands just in Shropshire, on the very border of the British frontier. It is $17 \frac{1}{2}$ miles from Shrewsbury, 11 from Llangollen, and $179 \frac{1}{2}$ from London. The country for several miles round is delightfully varied with hills, vales, wood, and water, and abounds in rich scenery. The prospect on the Montgomery side is terminated abruptly by the august ridge of the prominent mountains of Breiddyn. It is upon higher ground than any other town in Shropshire."

The Walls referred to by these writers were erected, as we have already stated, by Edward I. (probably under the superintendance of his celebrated architect Elreton, who built both 


\section{THE GATES.}

Conway and Caernarvon castles), that he might secure Oswestry as a key to his intended conquest of Wales, and render it less liable to the plundering incursions of the Welsh. These walls were about a mile in circumference, with a skilfully-made intrenchment on the outside, which could be filled with water from the springs in the vicinity. Some remains of this ancient fortification may still be traced, and part of its boundary-line is designated, up to the present time, as "the Walls."

There were four Gates, the only inlets into the town, and they stood as strong fortresses in times of disquietude and danger. As the town advanced in trade and commerce the Gates became exceedingly inconvenient for the passage of carriages and merchandize, and in 1766, the Black-Gate was taken down by consent of Earl Powis, the lord of the manor. Rylance assures us that "Black-Gate was demolished in consequence of its having become so low in the arch, that loads could scarce go under, having been rendered so by several pavements being put one over the other to repair the street, and make a vent for the water, which made the passage through it bad."

The convenience rendered to the town by the removal of the Black-Gate induced the Corporation to obtain the consent of the lord of the manor to the removal of the three other Gates. In 1782 an arrangement was accordingly made for their demolition, and the materials were used in the erection of the borough prison. The New-Gate was' erected in the reign of Edward II., and was used as a prison and guard-room 93

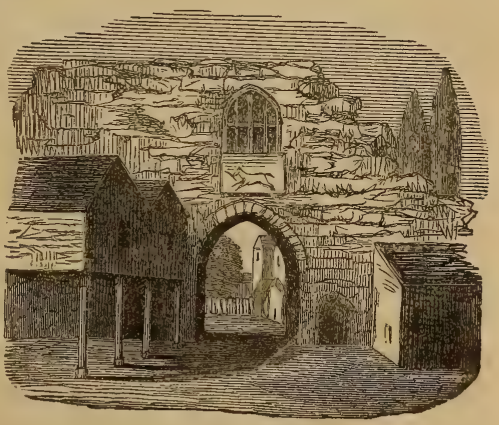

THE NEW GATE, 


\section{THE STREETS.}

for the soldiers. Over the New-Gate (as is seen in our engraving) was the figure of a horse in full speed, with an oaken bough in his mouth. Pennant remarks, "There is a conjecture, but I will not pretend to say how well warranted, that it alluded to the generous breed of horses which Powysland (of which this was part) was famous for, derived from some fine Spanish stallions introduced by Robert de Belesme, Earl of Shrewsbury."

Beatrice Gate is said to have been named in compliment to Beatrice, the Queen of Henry IV., and in all probability was built in that king's reign, as his sojourn in this district, during

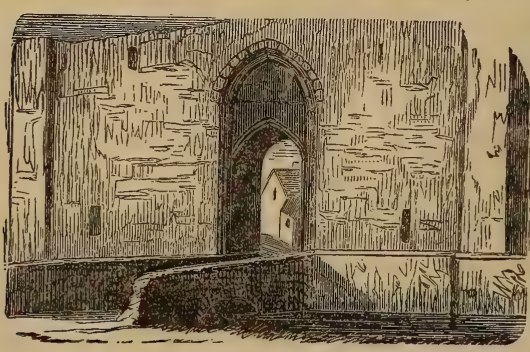

BEATRICE GATE. his long onslaughts upon the Welsh, connected him much with the neighbourhood. The gate was a handsome building, with a guard-house on each side, and over it the arms of the Fitz-Alans (a lion rampant). It is said to have been built by Thomas, Earl of Arundel.

Willow-Gate, or Wallia-Gate, derived its name from the road, in which the gate was situate, leading directly into Wales.

The borough has now assumed, from a number of improvements made in it, a highly-respectable appearance. ChurchStreet may vie, in neatness and public accommodation, with the leading thoroughfare of any similarly-sized town in the kingdom. Willow-Street is an active business thoroughfare, the two Banks and the Post-Office being situated there; Beatrice Street is the only thoroughfare to the Railway Station, and is therefore, with Leg-Street, the chief street of traffic. Bailey-Street, principally confined to shops, is a leading 


\section{THE STREETS.}

approach to the Powys Market, Guildhall, and public offices; whilst Upper Brook-Street is a pleasant location, and will doubtless soon become a favourite site for villa residences; at least, its beautiful situation, and the fine healthy country to which it is proximate, entitle it to such a distinction, Salop Road is on the march of improvement, and some good modern houses are erected in it; but yet its dwellings are irregular in size and appearance, and some time may elapse before it exhibits much of harmony or attraction, as a leading thoroughfare, unless the projected railway extension through the town gives, as may reasonably be expected, a stimulus to house-building in this district. The innovating hand of modern improvement has not hitherto effected much change in the central and more dense portions of the town. Let us "wait a little longer," and the unsightly dwellings deemed palaces by our forefathers, but which, compared with modern domestic houses, are little better than huts or hovels, will give place to habitations worthy of this age, so properly distinguished for its sanatory regulations and general progress. Such ancient and dilapidated buildings are mere figments of days gone past, and atone not, by their pictorial beauty, for their ruined and desolate condition. The flagging of the leading public streets, recently determined upon, and which has been partly carried into effect, will be one of the greatest improvements already adopted in the borough The principal thoroughfares in the entire town will speedily be flagged in the same style, so that in a short time the inhabitants, ladies especially, will be able to perambulate the streets, and amuse themselves "a-shopping," without paying for it the hard penalty of walking in their fashionable boots or slippers over a flinty pavement. This improvement is being effected from the funds of a voluntary subscription, to which a large number of the professional gentry and trading classes have liberally subscribed. The various roads leading from the town are wide and well-constructed, and are generally kept in a good traveilling condition. 


\section{LIGHTING THE TOWN.}

The town is lighted with gas, and has been so for many years past. The honour of introducing gas-light into Oswestry is due to Mr. Robert Roberts, civil engineer, a man of much talent in his profession, and of singular perseverance and industry. The origin of lighting the town with gas may be told in a few words. In the year $1819 \mathrm{Mr}$. Charles Stanton, at that time Manager of the Oswestry Theatre, which had been recently built, entered into an arrangement with $\mathrm{Mr}$. Roberts to light the Theatre during the season. Mr. Roberts had been hitherto experimenting on a small scale, and was not fully prepared to enter upon so important a piece of work as illuminating the Theatre. His persevering habits prevailed, and he agreed with Mr. Stanton that the Theatre should be lighted on a certain evening. To introduce gas into a large public building was deemed an event of no common magnitude in those days. The appointed evening, in September 1819, at length arrived, and Mr. Roberts succeeded in lighting the Theatre with a brilliant gas, which astonished all beholders. The performances on that evening were for the benefit of Miss Stanton, the Manager's daughter. Some tradesmen in the town quickly availed themselves of this new light; others followed in the wake; and in the winter season of 1821, the leading streets of the town were for the first time illuminated with gas. Places of religious worship soon afterwards adopted gas. The Welsh Methodist Chapel, in WillowStreet, first used it; the Wesleyan Methodist Chapel, Salop-Road, followed; and the Old Parish Church, then and still under the vicarage of the Rev. Thomas Salwey, was afterwards lighted, forty burners being introduced, including lights at the entrance doors. The other places of religious worship quickly followed the example; and in a very few years gas became the universal light in all public places, private houses, and commercial and trading establishments. In 1821 the public, or street-lamps, were only 10 in number; there were 123 private lights; and one chapel lighted with five lights. In 1854 there were-private lights, 925 ; public 


\section{MARKETS AND FAIRS.}

lamps, 66; Church and Chapel lights, 112. The lighting of the borough has been much improved since gas was first introduced here. It is still under the superintendence of Mr. Roberts, who, now an octogenarian, is of hale health, and of as active and bustling habits as he was in the days of his youth.

Oswestry is a market-town, and the chief market is held every Wednesday. It is abundantly supplied from the surrounding highly-cultivated agricultural country, and the articles brought for sale are generally of the very best quality. Welsh mutton, poultry, and fruits of rare delicacy are among the choice morsels which the exquisite gourmand may ever find, in their due season, in the Oswestry market. Apples and pears, produced in the vicinity, and offered for sale here, might successfully vie with the best of those fruits grown in Guernsey, Jersey, or the sunny orchards of Kent. There is a small market held on the Saturday, principally for the accommodation of the numerous labouring classes employed in the neighbourhood.

Twelve Farrs are also held in the town, all of which are conducted with great spirit, and attended by a large class of buyers and sellers. A Fair is held on the first Wednesday in every month.

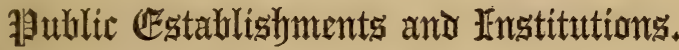

Imagine a party of strangers visiting Oswestry, having heard much spoken in favour of its neatness and beauty, and the picturesque scenery by which it is surrounded; and stretch forth your imagination, gentle reader, by supposing that this party have been comfortably supplied with viands, and perchance "the cup which cheers, but not inebriates," by mine host of the Cross Keys or the Wynnstay Arms. Having discussed these good things, they may perhaps hasten out in quest of "the lions" of the place. "Let us away to the 
Museum!" probably exclaims one of the ladies of the party who is ever in search of the utile as well as the dulce. "This is a charming spot," she perhaps adds, "for mineralogical and geological curiosities. 'The country, we are told, abounds in productive lead, copper, and coal mines. We shall surely collect much useful information in this practical and exploratory district, and return home wiser than when we came." "Bravissimo!" may be the cry and echo of most of the party, "Miss Aimwell is ever zealous in good works, and to-day she is bent upon providing for us no common store of rational pleasure and information. Let us hasten to the Museum, therefore, at once." The party, we suppose-for it is merely a fancy sketch-hie away towards the imaginary Museum, full of glee, anticipating the pleasure of exchanging compliments with the Curator, and one Director at least, and of inspecting a carefully-selected collection of natural curiosities, comprising, of course, attractive productions in the mineral world; specimens in ornithology; some of the many wonders and "gems of purest ray serene," snatched from the deep caverns of the ocean; rare marbles and pebbles chiselled out of rocks and caves, mountains and dells; botanical rarities, and floral, horticultural, native and exotic products; with gatherings from the realms of art, science, fancy, and literature. Do the imaginary party discover the Museum, or a Public Library, or any Institution whatever, in which Lord Bacon's axiom is illustrated, that "knowledge is power?" No such thing is in existence. The fancied party-or fanciful party, as some people would denominate them-have been in search of " the baseless fabric of a vision." Like Puff, in Sheridan's "Critic," they might say, with a slight interpolation,

"The Museum we cannot see,

Because it's not in sight!"'

Turning from the gay to the grave, we reiterate, there is no Museum in the town; nor even a Public Library, on a scale worthy of so respectable a community. We wish it were 98 


\section{THE POST OFFICE.}

otherwise; and the day is not far off, we trust, when the reproach will be wiped away, and Oswestry shall shew an example in this respect deserving of all praise.

\section{THE POST OFFICE}

Is situated in Willow-Street. Post-Mistress, Miss Sarah Babington, who has held her appointment since May, 1831. The Post Office was removed from Church-Street to WillowStreet, in October, 1839.

DESPATCH OF LETTERS, \&c.

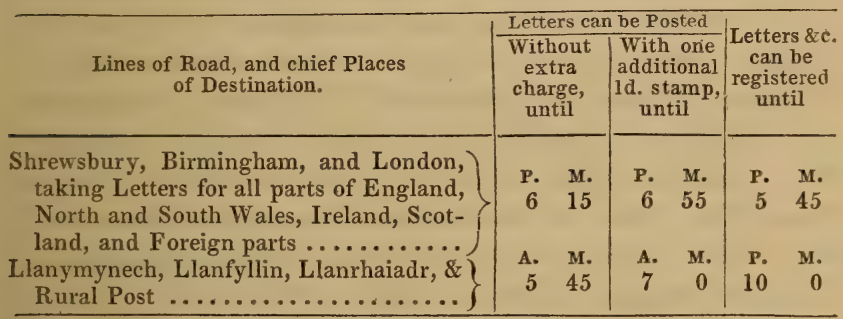

DELIVERY.

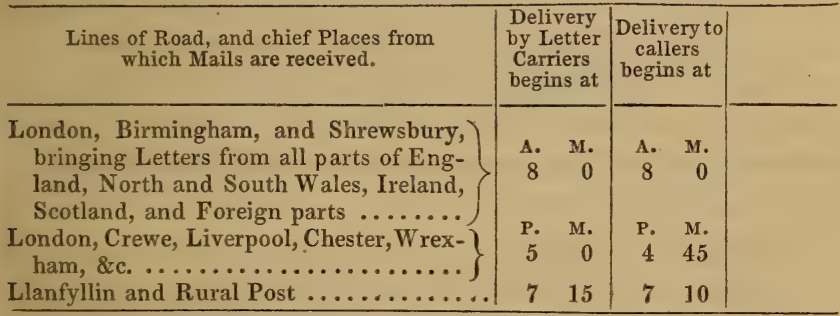

On Sundays there is only one Delivery by Letter Carriers (commencing at 8 a. m.), and Letters are delivered at the Window, from 8 until 10 a. m. only.

\section{REGULATIONS.}

Ordinary Business:-From the beginning of March to the end of October, this Office is, on Week-days, opened to the Public, for ordinary Business, at $7 \mathrm{a}$. m., and during the remaining months at half-past 7 . It is always closed at 10 p. $\mathrm{m}$. On Sunday the Office is open only from 8 till 10 a. m. ; but the Letter Box remains open as on other days. 


\section{THE BANKS.}

The inhabitants of Oswestry have now the privilege of receiving letters from London, both by the evening and morning mails. The new postal regulation, by which letters may be posted in London in the evening, after seven o'clock, and up to eight in the morning, is of great importance to tradesmen and others in Oswestry, as it enables them to reply to such letters on the evening on which they are delivered.

\section{THE BANKS.}

There are two Banks in the town. The OLd BANk, under the firm of "Croxon, Jones, Longueville, and Co.", is situated in Willow-Street, and has been established for upwards of seventy years. The original co-partners were Messrs. Gibbons, Croxon, and Sheppard. The present co-partners are Thomas Longueville Longueville, Esq., John Croxon, Esq., Richard Jones Croxon, Esq., and James Thomas Jones, Esq., who is also Acting Manager. Mr. Jones's father (Mr. Charles Thomas Jones) likewise discharged the duties of Manager of this Bank for the long period of thirty-five years. In such capacity, also in that of Chief Magistrate, and as a warm friend to every useful institution in the borough, he earned the grateful esteem of his fellowtownsmen. This Bank issues $£ 5$ notes, payable here or in London: issue limited by law to $£ 18,470$. Circulation, on an average of the last five years, $£ 10,180$.-Draw on Masterman and Co., Nicholas Lane, London.

The North and South Wales Bank, also situated in Willow-Street, is a Branch to the Bank bearing that title, established April, 1836, in Liverpool. The Oswestry Branch was opened June, 1836. There are fifteen Branches of the North and South Wales Bank established in the Principality and the Borders. Manager :-Mr. F. Roberts, appointed September, 1845.-Draw on the London and Westminster Bank.

\section{THE SAVINGS' BANK,}

On the Bailey Head, was established in 1818; and at the present time it is in a state of great prosperity, showing the 


\section{THE SAVINGS' BANK.}

careful and economic habits of a large portion of the labouring classes in this thriving district. From the annual account of the Trustees of the Bank, ending 20th November, 1854, it appears, that the balance in favour of the Depositors amounted to $£ 69,975$ 18s. 11d. The number of Depositors whose respective balances, including interest, did not exceed $£ 1$ each, was 77 ; of those $£ 1$, and not exceeding $£ 5,303$; ditto above $£ 5$, and not exceeding $£ 10,270$; ditto above $£ 10$,

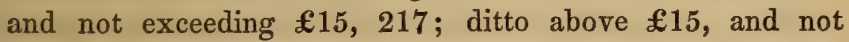
exceeding $£ 20,146$; ditto above $£ 20$, and not exceeding $£ 30,253$; ditto above $£ 30$, and not exceeding $£ 40,194$; ditto above $£ 40$, and not exceeding $£ 50,113$; ditto above

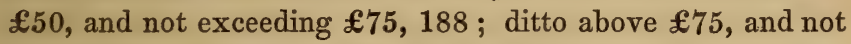
exceeding $£ 100,89$; ditto above $£ 100$, and not exceeding $£ 125,49$; ditto above $£ 125$, and not exceeding $£ 150,23$; ditto above $£ 150$, and not exceeding $£ 200,41$; ditto exceeding $£ 200,2$. The total number of Depositors was 1965 ; Charitable Societies, 30; and Friendly Societies, 31. The total number of accounts was 2026. The affairs of the Bank are conducted by ten Trustees and fourteen Managers.

Treasurer :-Thomas Longueville Longueville, Esq. Secretary :-Mr. John Hughes.

The Bank is open for business every Wednesday, from twelve till two o'clock.

\section{THE STAMP OFFICE}

Is situated in Leg-Street. Sub-Distributor, Mr. George Lewis.

\section{THE MARKETS.}

Until very recently the town of Oswestry had not provided any market-sites worthy of the name. As the town, however, advanced in population and trading pursuits, and agriculture and farming in general progressed in the neighbourhood, the want of new and convenient public markets began to 


\section{THE MARKETS.}

be seriously felt, and most of the inhabitants, and gentlemen connected with the neighbourhood, were disposed to contribute towards the completion of such desirable improvements. A very liberal spirit was manifested in favour of so excellent a design ; a public subscription was set on foot; and at length the sum of $£ 3202$ was raised, which was laid out towards erecting the Cross Market, as that was considered to be the most desirable to commence upon. But this sum being found insufficient to cover the cost even of this Market, it was agreed by the Town Council to apply to Parliament for an Act, empowering them to effect further Market Improvements in the borough, and to raise $£ 5000$ for that purpose. Accordingly a Bill was presented to Parliament, in 1848, entitled "The Oswestry Markets and Fairs Bill," and in February of that year Mr. Fowler, Surveying Officer of the Commissioners of Woods and Forests, attended at Oswestry, to hear evidence upon the proposed markets. R. J. Croxon, Esq., TownClerk, appeared for the promoters, and having pointed out, in a long address, the evils arising from holding the Fairs and Markets in the public streets, called several witnesses in support of his statement. Mr. Fowler reported favourably of the objects of the promoters; and in the same Session of Parliament the Act received the royal assent. The measure being so far successful, no time was lost in carrying out this creditable project; and on June 6th, 1849, the Cross Market, for the sale of butter, eggs, poultry, fruit and vegetables, was opened. Part of the market is also used for the sale of butchers' meat. The Powis Market-HaLl, forming one side of the Bailey Square, was opened on the same day. The chief part of the buildings of which the Powis Market is composed, as well as the site on which the new portion of the Market stands, was presented to the town by the late Earl of Powis, Lord of the Manor and Lordship of Oswestry, his Lordship merely stipulating that he and his successors should have the use of the new Guildhall when the same was wanted for holding the Manor Courts. The site on which 
.

. .

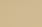




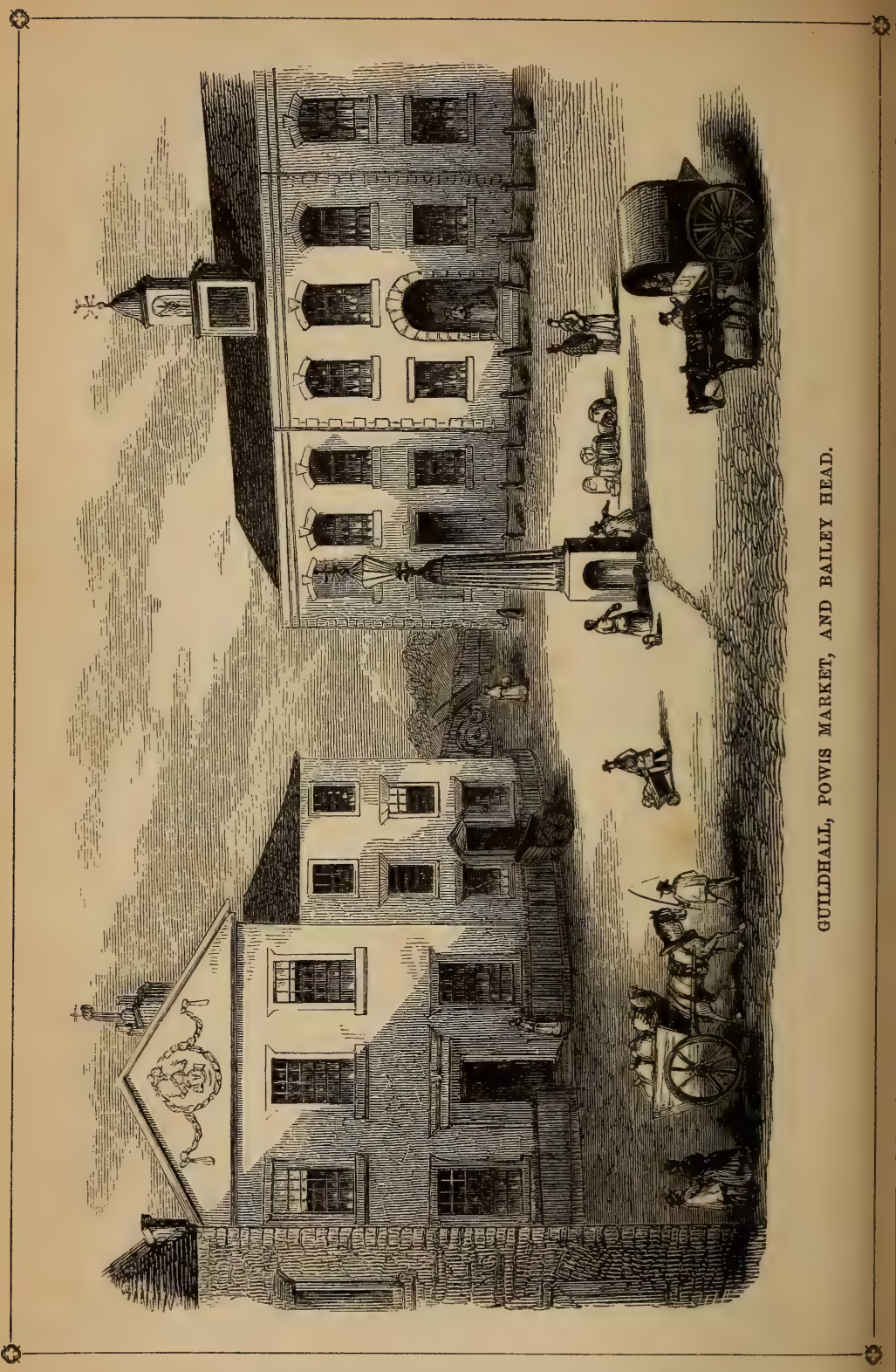




\section{THE MARKETS.}

the Cross Market was built, being in the centre of the town, had been covered with shops and dwellings, all of which were purchased at a cost of upwards of $£ 2,700$. Mr. Thomas Penson was the architect employed on this Market, and Messrs. Griffith and William Morris contracted for its erection. The market is spacious and convenient, is covered in, and has three entrances, the main one being from the Cross. The Powis Market-Hall, in which accommodation is given to farmers and general dealers in cheese, butter, and grain, is a plain stone-fronted edifice, with a high clock turret. The front part of the building was formerly used as the GuildHall, at the back of which new buildings have been erected, in brick, and partly covered with glass. This market has been found to be exceedingly convenient, especially in the winter season; and the accommodation thus rendered to buyers and sellers has contributed so much to increase their number, that a considerable extension to the market is contemplated. The Cattle Market comprises an extensive piece of ground, situated between Church-Street and Croxon's Square, which was purchased from $\mathrm{Mr}$. George Withers Edwards, at a cost of $£ 1050$. It is exceedingly well attended, and fully justifies the expectations of all parties engaged in its formation. The Horse MARKET is situated at the back of the Powis Market. The site on which it is held, comprising 4256 square yards, was purchased for $£ 279$. Both of these markets were opened on Wednesday, 4th July, 1849.-Mr. George Cooper is Treasurer of the Markets; and Mr. John Donald Superintendent.

Most of the leading gentlemen of the town had taken an active interest in the formation of the new markets, and no one was more zealously engaged in promoting them than Peploe Cartwright, Esq., to whom, after the completion of these public improvements, a service of plate, consisting of a silver salver, tureen, and four corner dishes, was presented on behalf of the Corporation and a numerous body of the inhabitants of 103 


\section{THE GAS-WORKS.}

the town and neighbourhood, as a testimony of their sense of his many "public services in forwarding the improvements of the town, and in particular for his able, zealous, and untiring exertions in promoting the establishment of the fairs and market accommodations," The presentation of the plate took place December 26th, 1850, in the Powis Market-Hall, in the presence of a numerous assembly. The Recorder of the borough, John Robert Kenyon, Esq., presented the plate, in an appropriate and eloquent speech; and Mr. Cartwright responded with ability and feeling. On the same day, as a further testimonial to Mr. Cartwright, a public dinner was given to him, at the Wynnstay Arms Hotel, on which occasion the festive enthusiasm which distinguishes the Salopian gentry was more than ordinarily displayed, The entire proceedings of the day passed off with the utmost satisfaction.

\section{THE GAS-WORKS}

Were erected in 1842 , at the sole expense of Mr. Robert Roberts, the proprietor, on a piece of land situated near Gallows-tree Bank turnpike gate, the original works in Willow-Street having long before been found too small and inconvenient to meet the increasing requirements of the town. The new works were built on an extended scale, and comprise a retort-house, purifying house, with a large tank and gasometer. The apparatus is of the usual character, including condenser, purifier, scrub, with fire-clay retorts, hydraulic main, \&c. The chimney is square, and spiral in form, tapering to the top, and forms an object of interest on the approach to the town from Shrewsbury.

\section{THE THEATRE}

Is a small neat building in Willow-Street, but is not often occupied, It is the property of William Ormsby Gore, Esq., who, when he built it, doubtless considered he was providing means of rational entertainment for the inhabitants. But Melpomene and Thalia have lost their charms in this district; 104 
and the immortal works of Shakspeare, Jonson, Fletcher, Massinger, Colman, Sheridan, Knowles, Bulwer, and others, are doomed to shed their fragrance only in the library or study. Thirty years ago the acted drama was deemed a genial and instructive amusement, and the boxes, pit, and gallery of Oswestry Theatre were frequently crowded with fashionable and attentive audiences. About the period to which we refer the Theatre was under the careful and clever management of Mr. Charles Stanton, who, with his family, "gained golden opinions," and a more than decent competence, by his histrionic labours. During the time he presided over the Thespian realm, he succeeded in attaching to his corps theatrique many ladies and gentlemen of talent and high principle, who afterwards figured with advantage in more extended spheres of their profession; and whilst he held the reins of government, he deserved and received the good opinion of his supporters. After having thus briefly adverted to theatricals in Oswestry, it will not be inappropriate to mention, that on no occasion, perhaps, in the history of provincial dramatic performances, were more brilliant and exhilarating scenes displayed than in 1822, when a number of ladies and gentlemen, most of them residents of the town or neighbourhood, kindly volunteered their services as dramatis personce in a series of dramatic productions. Three performances were determined upon, that a fund might be raised for establishing in the town a Public Library. The first took place February 15th, when the comedy of "Speed the Plough," and the afterpiece of "The Review," were presented. An original Prologue, from the pen of William Ormsby Gore, Esq., was spoken by the characters. The receipts of the night were $£ 76$ 12s. 6 d. On the evening of May 23rd, in the same year, Colman's comedy of "The Heir at Law," and the afterpiece of "The Review," were performed. Mr. Alderman Salisbury, a hale octogenarian, spoke a Prologue to the play, attributed to Garrick. Colman's Epilogue was spoken by the characters. The receipts on this occasion were $\mathfrak{£ 4 7}$. The third performance, 


\section{A PROLOGUE.}

May 25th, consisted of "Speed the Plough," and the afterpiece of "High Life below Stairs." Receipts £24. The late J. F. M. Dovaston, Esq., who had taken much interest in these performances, wrote a Prologue to "The Heir at Law," and it was intended that he should enact the part of Lord Duberly, and deliver his own witty effusion. Some differences, however, arose, and he did not therefore take any part in the performances. Although the total receipts amounted to the handsome sum of $£ 14712 \mathrm{~s}$. 6 d., yet the expense of scenery, \&c., exhausted nearly all the fund, and the original design, of establishing a Public Library, failed.

Mr. Dovaston's Prologue is given in his volume of Poems, published in 1825. It forms part of the literary history of Oswestry, and we therefore make no apology for transferring it to our pages :-

"PROLOGUE,

"To a Play for the Benefit of a PUBLIc Lrbrary; spoken in the character of Lord Duberly (formerly Old Daniel Dowlas, the Grocer).

Oswestry Theatre, 1822.

"Though here I struts, a lord so great and gay,

I was but tallow-chandler t'other day;

I've riches, dress, good dinners, rank, and station,

But what are all these without headication?

If I dines out, and says but aye or no, Sir,

As sure as figs is figs-out peeps the Grocer.

I sees as clear as isinglass or varnish,

Wealth without larnin is-but tawdry tarnish:

Poor men, of Manners, Sense, and Wit all handy,

Are to Society-bright Sugar-candy;

While ev'n in Senate, Bar, Church, Tabernacle,

Brass without Brains is-Brimstone without Treacle.

"I to the Playhouse goes, to see their vainery,

And (tho' enraptured with their fine new Scenery)

I knows not what their wit or weeping takes there,

Nor what they means by SHERIDAN or SHAKSPEARE.

"We've got no Books-and this our show's all brib'ry

To ax good-natur'd folks to fill our LiBREY.

We gives books to the poor-and all approves them;

Then why not by example shew we loves them? 


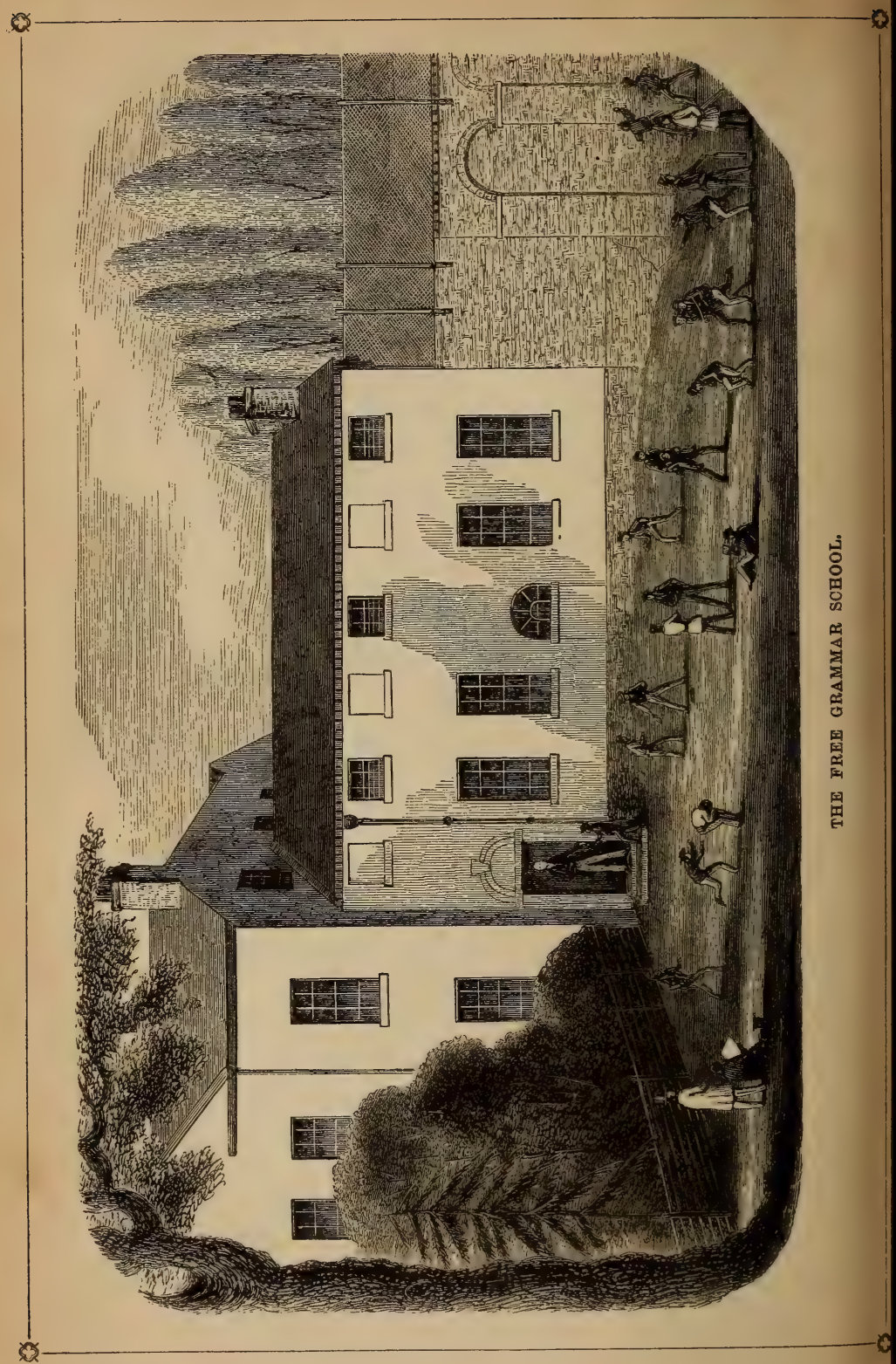




\section{HOTELS.}

" Knowledge, in this world's counting-house's mass,

Is good store candle, mould, or brilliant gas,

To keep our day-book faithful; which, when furl'd,

Will post us fitter for a future world."

It is worthy of notice also, that in the same year in which the performances were given in behalf of a Public Library, the celebrated actor, distinguished as "The Young Roscius," Mr. William Henry West Betty, appeared on the Oswestry Stage, and played several of his popular characters. Mr. Betty soon afterwards retired from public life; and for many years past has been residing in London, having earned a handsome fortune, enjoying his otium cum dignitate. He was a native of Shrewsbury, and in right of his mother was heir to the extensive estate of Hopton Wafers, in Shropshire.

\section{THE HOTELS.}

The principal Hotels in the town are, the Cross Keys, the Wynnstay Arms, the Queen's Head, and Osburn's Commercial. All these Hotels are well-conducted, and are much frequented by commercial travellers, private families, and tourists through the Principality and Border Lands.

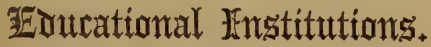

\section{THE FREE GRAMMAR SCHOOL.}

This ancient and valuable institution was founded and endowed in the reign of Henry IV., between 1399 and 1413, by Mr. David Holbetche, "a lawyer, steward of the towne and lordship," and who in the same reign was "made a denizen or free citizen of England." The munificent founder granted, for the maintenance of a schoolmaster, and the reparation of the school-house, certain lands in Sweeney, Treflach, Maesbury, and Crickheath, in addition to a house on the south-west side of the Parish Church. By an inquisition under a Commission of charitable uses, taken at Oswestry, 17th September, 1634, it was found that "how the said lands were granted, or to whom, or by whom, they were to be let, 107 


\section{THE FREE GRAMMAR SCHOOL.}

was not known, but that the bailiffs of the town of Oswestry had, for the most part, jointly let the same:" and it was further found, "that upon the granting of certain leases therein-mentioned, certain sums had been paid to the bailiffs, or to their use, as a gratuity for making such leases; and that they had cut timber upon the said estates which they had disposed of for their own use." In April, 1635, the Commissioners made a decree, stating "that they had not found that the bailiffs of Oswestry were trusted by the founder in ordering and disposing of the said school and school-lands, but that they had done the same without any just authority; and that if they had been trusted therein, they had manifestly abused the trust, in making leases at an under-value, and for secret rewards for themselves, and in committing great waste upon the timber-trees growing upon the said premises; the said Commissioners decreed, that the bailiffs of the said town should be for ever discharged and excluded from any trust, or intermeddling with the said school and school-lands, or from anything which should concern the same, otherwise than was thereafter limited; that the nomination and placing of the schoolmaster should be left to the bishop of the diocese according to the law; that the schoolmaster for the time being should let the premises in possession, and not in reversion, for the term of seven years, at the yearly rents mentioned in a particular of the lands referred to in the inquisition, or more, and so as the consent of the bishop and chancellor of the said diocese, and of the bailiffs of the said town, or any two of them, whereof the bishop should be one, should be first had in writing, for the making of such leases; that neither the master nor any of the tenants should cut or lop any timbertrees growing upon the premises without the like consent; that the then schoolmaster should, within one year, make a true terrier of all the school-lands and tenements, whereof one part should be delivered to the bishop, to be kept in his registrar's office, and the other to be delivered to the bailiffs, to be entered in the town-book. And the said Commissioners 


\section{THE FREE GRAMMAR SCHOOL.}

further ordered, that the schoolmaster should always have an usher, and allow him $£ 10$ a-year, and so much more out of the improved rents, as the said bishop for the time being should think fit; so that the whole stipend of the usher should not exceed $\mathfrak{£ 1 5}$; and that the schoolmaster for the time being should keep the school-house in repair."

A terrier of the school-lands was accordingly taken, and the report was as follows:-Crickheath, 24a. 1r. 37p.; Treflach, 20a. 1r. 5p.; Sweeney, 74a. 0r. 10p.; Maesbury, 12a.0r. 29p. The lands in Treflach mentioned in the terrier had been held for many years at the ancient rents, without any variation; and the Rev. James Donne, D. D. (the former master), brought actions of ejectment against the late Lazarus Venables, Esq., and Mrs. Hilditch, who held the lands, and insisted upon their right to hold them, paying the accustomed rents. Upon the trial of these actions verdicts were given in favour of Dr. Donne, and the lands being very much dispersed and intermixed with those belonging to the defendants, the judge recommended that lands equal in value, and lying together, should be given up to the plaintiff, instead of the identical lands which were the subject of the suits. This recommendation was cordially adopted by all parties concerned, and further litigation was therefore avoided.

Dr. Donne, through whose exertions these valuable properties were recovered for Oswestry School, may justly be looked upon as its second Founder. He raised the character of the School from comparative obscurity to being second to none of the Grammar Schools of England. His memory is held in affectionate remembrance by his pupils, who, to testify their feelings, raised a handsome Memorial in Oswestry Parish Church. The inscription on this Monument speaks deservedly of a revered Master, and does credit to the elegant scholarship and affectionate feelings of the distinguished Pupil who composed it.

Further advantageous exchanges of land have taken place 109 
during the time of the present Master, which have resulted in attaching some of the most valuable land in the Liberties of Oswestry and Township of Weston to Oswestry School.

The Rents of the property accruing to the benefit of the School, including a payment of $£ 112 \mathrm{~s} .0 \mathrm{~d}$. from the receiver of the Crown Rents, in respect of a sum of $£ 2$ charged on the land revenues, amount to $£ 27110$ s. 2d. Some land around the School-House is not included in this statement, so that the Endowment of the School may be considered to amount to $£ 300$ per annum.

In 1776 the late Sir W. W. Wynn, Bart., gave a piece of - land, called Cae Groes, comprising nearly eight acres, upon which the present School-House was erected, charged with a rent of $£ 12$ per annum, to the heirs of Sir W. W. Wynn; and the sum of $£ 7794$ s. 8 d. was subsequently subscribed towards completing the structure, the balance of expenses having been borne by Dr. Donne.

The School is open to all boys born in the parish of Oswestry, for instruction in English, Latin, and Greek; but it is expected that they should be able to read before they are admitted. For the before-mentioned studies no payment is demanded from the boys on the Foundation, except 12s. $6 \mathrm{~d}$. for entrance, and 2s. a-year for fire-money. The present Master is the Rev. Stephen Donne, A. M., who has filled the office since his appointment in 1833 with singular merit and success, and who has had the good fortune, during his connexion with the School, to acquire the esteem and confidence of his pupils, and the warm approval and regard of their parents and guardians.

The course of instruction in the School is Classical and Mathematical, embracing strict attention to Religious knowledge, with History and Geography, both Ancient and Modern; and whilst pupils are prepared for the Universities, and Addiscombe, Woolwich, and Sandhurst, boys who have in view the Profession of the Law or a Commercial life, in addition to their other studies, are carefully trained in Writing, 


\section{THE FREE GRAMMAR SCHOOL.}

Arithmetic, and Book-keeping. The Head Master receives Boarders into his House, who are treated in a liberal and gentlemanly spirit. Several Pupils from this School have, during the time of the late and present Master, highly distinguished themselves at Cambridge, Oxford, Dublin, Addiscombe, and Woolwich.

The late Rev. James Donne, D. D., retired from the School in 1833, and died at Llanyblodwel Vicarage (which he had re-built), January 23rd, 1844.

The early Masters of the School we are unable to discover. Our list of appointments commences with the year 1537 :-

\section{LIST OF HEAD MASTERS.}

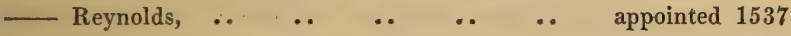

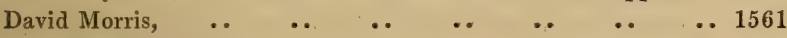

Vicar of Llansilin 1561.

John Berkley, D. D. $\quad \ldots \quad$.

Rector of Llanddoget 1606. He became Vicar of Llansannan 1611, Rector of Newtown 1613, Rector of Llanfyllin 1614, Prebendary of Llanvair Second Comportion 1621, and Rector of Llandyssil 1622.

John Kyffin

$\begin{array}{lllllllll}\text { Lloyd } & \ldots & \ldots & \ldots & \ldots & \ldots & \ldots & \ldots & 1624\end{array}$

$\begin{array}{lllllll}\text {. } & \text {. } & \text {. } & \text {. } & \text {. } & \text {. } & \text {. }\end{array}$

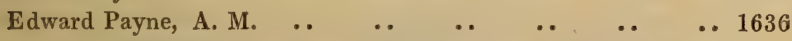

Rector of Cemmaes 1661, Vicar of Kinnerley 1668. This gentleman was ejected in the time of Oliver Cromwell's Usurpation.

William Griffiths

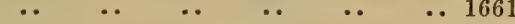

Rector of Cilken, 1673, Canon 1675, Rector of Llanrwst 1677, Prebendary of Myfod and Rector of Castle-Careinion 1678, and Rector of Christleton, Cheshire.

John Evans

Rector of Newtown 1666, Canon 1681, and Rector of Berriew 1686.

Edward Wicken

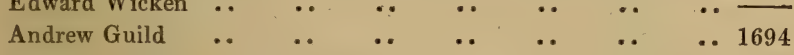

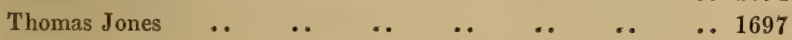

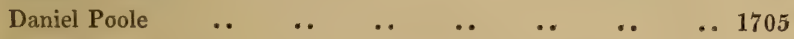

$\begin{array}{llllllll}\text { Lloyd } & \ldots & \ldots & \ldots & \ldots & \ldots & \ldots & \ldots \\ \text { Robert Patrick } & \ldots & \ldots & \ldots & \ldots & \ldots & \ldots & \ldots\end{array}$

Rector of Cemmaes 1717, Canon 1718 , and Rector of Mallwyd 1733.

John Skye

Peter Morris

.. 1763 
THE NATIONAL SCHOOLS.

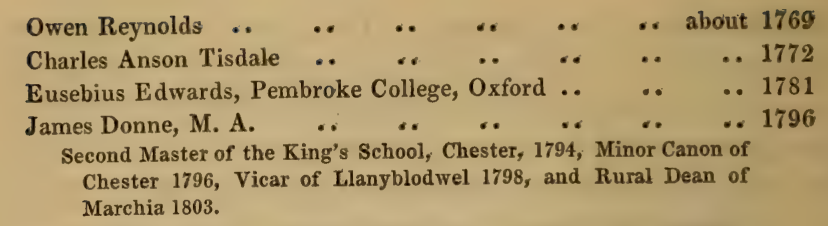

Stephen Donne, M. A., Scholar of St. John's College, Cambridge,

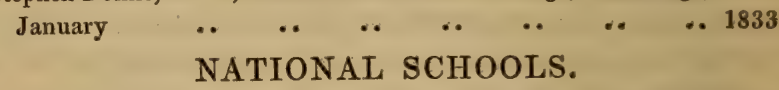

In the work of benevolence the borough of Oswestry has never acted with a niggardly hand. When the necessity of national education first engaged the sympathies of the community at large, Oswestry took a distinguished part in the good work, and liberally provided education for the children of the poor, who, until that period, had had none to help them. So early as the commencement of the last century a Charity School was established for the benefit of forty children, of whom twenty were clothed, and all taught by a mistress to read and spell. When the boys were made perfect in the reading of certain elementary books, they were transferred to a master; and the girls were fully instructed, besides reading and spelling, in spinning, knitting, and sewing. It is stated on one of the tables of benefactions in the Parish Church, that in $1713 \mathrm{Mr}$. Thomas Owen, Vicar of Oswestry, left the interest of $£ 20$ for the use of this Charity School; and that in 1716 the Rev. Daniel Poole, chief Schoolmaster of the town, left the interest of $£ 20$ for the like use. In a minute of vestry, dated July 5 th, 1737 , it is stated that $£ 32$ was laid out on the Poor-house in Church-Street, which sum, it is added, was paid out of the legacies of the Rev. T. Owen and the Rev. D. Poole. In December, in the same year, it was ordered at a vestry, that in lieu of the money laid out as mentioned in the preceding minute, forty shillings should be paid yearly toward maintaining the Charity School in the town of Oswestry. It does not appear what school was intended, or how long the payment was continued. 
The friends of education in Oswestry; still anxious for the well-being of the rising generation, united together in the year 1810 to carry out their benevolent intentions. In July of that year it was agreed, that the Guildhall should be appropriated for the reception of boys, and the school-room situated in the church-yard for the reception of girls, until rooms at the Bailey-Head should be properly fitted up for their instruction. A public notice was afterwards issued, announcing "That the Public Charity School, beloriging to the town and parish of Oswestry, is now open for the instruction of boys of the age of five year's and upwards." In November following, the boys' school was removed to the chapel of the House of Industry, the School Committee considering that such change would afford an opportunity to the children of parents residing in the country to attend the school. This plan partly failed, and soon afterwards convenient school-rooms, for boys and girls, were fitted up at the Bailey-Head, from plans by Mr. T. Jones, Architect. These schools were supported by general subscription and occasional aid from the National Society.

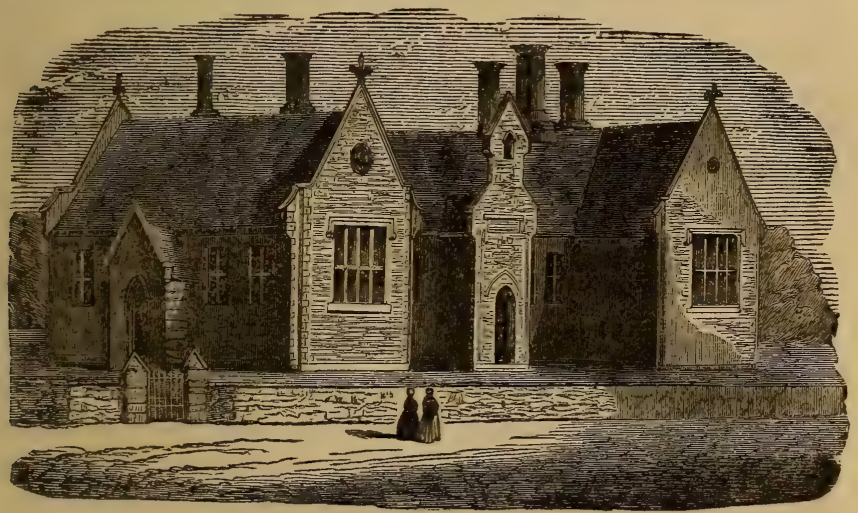

NATIONAL SCHOOLS.

At length it was deemed necessary to provide more spacious and convenient school-rooms, for the furtherance of the great 113 


\section{THE BRITISH SCHOOLS.}

object of education, and arrangements were made for accomplishing so important a design. A public subscription was entered into, and this was aided by grants of $£ 338$ from the Committee of Council on Education; $£ 200$ from the National Society; and a contribution of $£ 700$ from the funds of the Oswestry Church Sunday School. The present beautiful building was accordingly erected under the Welsh Walls, sufficient accommodation being rendered for an Infant School. The structure was designed by Mr. Penson, and raised by Mr.J. Vaughan, Builder. As a tribute of respect to the memory of the late Sir W. W. Wynn, Bart., the building was commenced on the 22nd of May, 1841, when his son, the present worthy possessor of Wynnstay, attained his majority. The sole control of the School is vested by the trust-deed in the Vicar of the parish for the time being. The number of children at present educated in the Schools is-Boys, 78 ; Girls, 64 ; Infants, 57.-Master, Mr. S. S. Lees ; Mistresses, Miss Whitfield and Miss Pierce.

\section{THE PARISH CHURCH SUNDAY SCHOOL}

Was established in 1831. A zealous interest is taken in its prosperity by the Clergy and many persons of wealth and influence in the town and neighbourhood. The average attendance at present is 280 Scholars; Teachers from 30 to 35 .

\section{THE BRITISH SCHOOLS}

Were erected in 1841 , at a cost, including the site, of about $£ 800$; the builder being Mr. James Vaughan.

They are held in trust for "the education of children and adults, or children only, of both sexes, of the labouring, manufacturing, and other classes, in the town and parish of Oswestry, and in the several parishes adjoining;" such education to be conducted on the principles of the British and Foreign School Society. The trust includes permission to use the premises on week days, prior to and after school hours 


\section{THE YOUNG MEN'S INSTITUTE.}

(i. e. before 9 a. m. and after 6 p. m.), for "such moral, literary, scientific, or other purposes," as shall be allowed in manner therein mentioned. The funds for the erection of the Schools having been subscribed chiefly by members of the congregation assembling at the Old Chapel, there is a trust assigning the use of the building on the sabbath to the Sabbath Schools connected with that place of worship.

The system of education on week days being conducted on the principles of the British and Foreign School Society, it need hardly be said that no denominational catechism or dogma is permitted to be taught; but the Holy Scriptures are in daily use.

The utility of the institution having become much crippled by a debt remaining on the building and an accumulation of current expenses, a special effort was made in the year 1854 to throw off the incubus. The generous efforts and contributions of friends in the town and neighbourhood, and others in various parts of the kingdom, aided by a Bazaar, not only effected the "consummation" so "devoutly to be wished," but also realized a fund applicable to the substantial repair of the building, and a needed supply of school materials.

The present Master and Mistress are-Mr. Farmer and Miss Jones.

\section{THE YOUNG MEN'S INSTITUTE}

Began its course about the year 1838. It was originated by the then minister of the Old Chapel (the Rev. W. Reeve), and a few members of his congregation, chiefly young men, who felt the importance of adopting some means calculated to promote the moral and intellectual advancement of the young men of the town, and which should offer to them a refuge and enticement, during the evening hours, from listlessness on the one hand, and from low and debasing pleasures on the other. 


\section{THE YOUNG MEN'S INSTITUTE.}

The meetings were for some time held in the vestry of the Old Chapel. When the British School-rooms were erected in the year 1841 the opportunity was taken of endeavouring to extend the benefits of the Institute, by transferring its meetings to the lower school-room. Still it was felt by its friends, that it was not so used or supported as they desired; but, necessity having no choice, no attempt was made for several years to change its location or enlarge its scope.

At the School-roor the Institute prospered for a considerable time, and did much good; but afterwards, from one cause or another, it drooped, and well nigh sank. Deeming it, however, too good a thing to die, and thinking it possible that many influential parties might have withheld their sympathy and aid, from an idea (erroneous though it was) that the Institution, from its antecedents and place of meeting, was not entirely unsectarian and liberal, its friends made a successful effort in the year 1850 to resuscitate it. The elergy and dissenting ministers of the town, together with several influential lay gentlemen, formed a committee, obtained the use of the Guild-Hall for the meetings, and raised very extended subscriptions. Many excellent lectures, professional and amateur, were delivered, and new life seemed for a time to flow in the veins of the Institute. The Guild-Hall being found inconvenient for the Library and Reading-room, these were removed to rooms over the Shop of Mr. Richard Jones, Hatter, at the Cross.

Subsequently, however, the falling-off of the subscriptions, and, it must be added, the backwardness of the young men generally to avail themselves of the privileges offered them, obliged the committee to relinquish these premises, and for more than a year past there seem to have been no meetings.

It is said that "all that's fair must fade." May we hope that the Young Men's Institute is only slumbering, and will not die, or, that dying, it will rise again to a stronger, happier, better life. 


\section{Benefrolent Enstitutions.}

\section{DISPENSARY AND BATHS.}

The establishment of these two institutions is honourable to the founders, and, we are glad to observe, of great benefit to the poor and needy afflicted with disease. The origin of both is part of the annals of the town, and claims especial record in our volume. We find that in the year 1828 a meeting of the leading gentlemen of Oswestry was held, for the purpose of endeavouring to establish a Dispensary. That assembly was presided over by William Ormsby Gore, Esq., and the benevolent institution was at once founded under most liberal auspices. Donations amounting to one hundred and sixty guineas were subscribed at the meeting, and a Committee was appointed, to carry out the objects of the Charity. At the same time a liberal amount in annual subscriptions was determined upon, that the new institution should be rendered permanent. The following parties formed the first Committee, \&c. :-

\section{President: \\ Wm. Ormsiy Gore, EsQ. \\ Committee of Management:}

The Hon. Thos. Kenyon,

T. Bulkeley OWen, EsQ.,

J. V. LovetT, ESQ.,

H. P. T. Aubrey, EsQ,

Rev. Thos. SALwey,

REv. G. N. K. LLOYD,
Robt. Morrali, Esq.,

T. L. Longuevilie, EsQ,

T. N. PARKer, EsQ.,

Rev. Thos. Hunt,

Rev. C. A. A. Lloyd,

Mr. Lucas.

Honorary Treasurer:-C. T. Jones, EsQ.

Visiting Physician:-Dr. Evans.

Surgeons:

Mr. MORRIS,

Mr. E. D. Bennion,

Mr. Cockereli,

Mr. Cartwright.

Dispenser and Secretary:-Mr. J. M. HaLes.

The original Dispensary rented for the Charity was situated in Lower Brook-Street; but the premises being found 


\section{THE DISPENSARY AND BATHS.}

too limited and inconvenient for the benevolent objects contemplated, a new building was suggested, and accordingly, in March, 1852, the Committee adopted a resolution to the effect, that it was desirable to erect a Dispensary, with Baths attached to it, for the accommodation of the public, as well as for the use of the patients of the institution. To carry out this excellent design a handsome subscription was entered into, amounting to between seven and eight hundred pounds ; to which was added, from the accumulated fund of the Dispensary, the sum of five hundred pounds. The

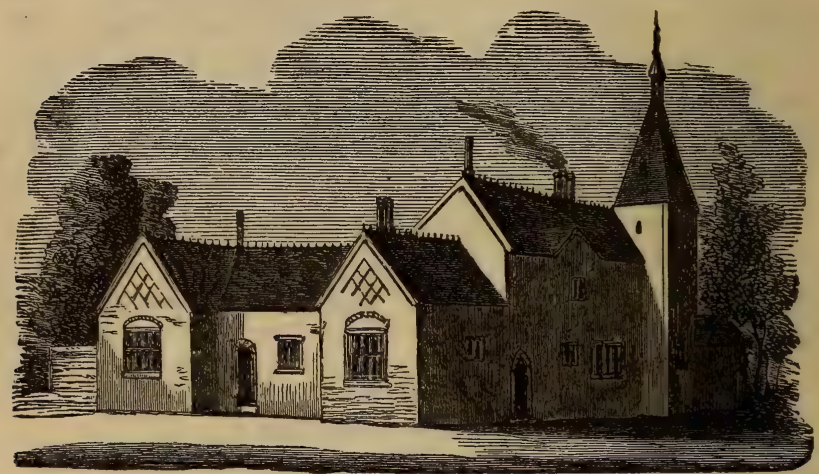

DISPENSARY AND BATHS.

present Dispensary and Baths were immediately erected from a design by R. Kyrke Penson, Esq., on ground near the site of the former Dispensary. The building is roomy and convenient, containing handsome and suitable rooms for the Dispensary, with the addition of Warm and Cold Baths, Shower Baths, a Vapour Bath, and Plunge Baths.

The number of patients who have partaken, within the last three years, of the benefits which the Dispensary affords, shows the necessity and value of the institution. From May, 1851, to May, 1852-Patients, 455. In 1853-Patients, 496. In 1854-Patients, 555. 


\section{THE HOUSE OF INDUSTRY.}

The Dispensary, with the Baths, was opened May 1st, 1854. Mr. Ormsby Gore still holds the office of President of the institution, and $\mathrm{Mr}$. Hales continues to officiate as Secretary and Dispenser. The Committee and officers are :-

\section{Committee of Management:}
E. Wright, EsQ.,
Rev. S. Donne,
REV. G. CAREW,
Rev. J. LuxMoore,
R. K. Penson, EsQ.,
J. V, LovetT, EsQ.,
Thos. Minshall, EsQ.,
Thos. Lovett, EsQ.,
Rowland J. Venables, EsQ.,
T. L. Longueville, EsQ.,
E. Williams, EsQ.,
John Croxon, Esq.

Treasurer:-J. T. Jones, EsQ.

Surgeons:

Mr. Cartwright,

Mr. Blaikie,

DR. FULLER,

Dr. Williams.

The Trustees to whom the site for the new Dispensary and Baths was conveyed are, William Ormsby Gore, Esq., Thomas Lovett, Esq., Edmund Wright, Esq., and Thomas Longueville Longueville, Esq.

The proposition for building the Dispensary with the addition of Baths originated with Edward Williams, Esq., of Lloran House; and his efficient and zealous efforts were used in promoting the benevolent design, which was most successfully accomplished in the end. In the prosperity of so valuable an institution all classes in the town and populous neighbourhood, who are blessed with this world's goods, should consider it a Christian privilege to take a lively interest, by contributing to its funds, and thus extending its usefulness among the labouring poor who have few to help them.

\section{THE HOUSE OF INDUSTRY,}

Situated on elevated ground near the river Morda, on the road from Oswestry to Welshpool, was erected by virtue of an Act of Parliament obtained in the year 1790, and opened for the reception of inmates April 28th, 1791. The first steward and matron were Mr. Thos. Cooper and Mrs. Cooper, 
who held those responsible situations for the long period of nearly thirty years. Directors were appointed, under the Act, to manage the affairs of the institution, on behalf of Oswestry town and parish, and the other parishes also thereby incorpo. rated: namely, Saint Martins, Selattyn, Whittington, West Felton, Ruyton, Kinnerley, Knockin, and Llanyblodwel, in the hundred of Oswestry, and county of Salop; that part of the parish of Llanymynech which lies in the hundred of Oswestry ; the parish of Chirk, in the county of Denbigh; and the parish of Llansilin, in the counties of Salop and Denbigh, The Directors held their first meeting on Monday, August 11th, 1791 : Chairman, John Lovett, Esq, Mayor of Oswestry. The building, of red brick, which still looks fresh and fair, cost $£ 12,000$. It has ever excited the attention of strangers, on account of its imposing stateliness of architecture, the exterior presenting, at the first view, the appearance of a fine old English baronial residence. Nicholson, in describing it thirty years ago, says, "it is a ridiculously-splendid brick building, intended, not for a purpose which its exterior seems to prompt, but for the abode of the indigent and wretched."

In 1851 a slight sensation was created in the united parishes of Oswestry by a proposal from Mr. Doyle, Poor-Law Inspector, to admit six additional parishes into union with the Oswestry Incorporation. The Poor-Law Board had some time before claimed a general authority over the Incorporation, to which the Directors, after a slight resistance, submitted. Public meetings of the rate-payers of the incorporated parishes were held, to consider Mr. Doyle's proposal, and one also was convened in the Old Church, Oswestry, on Saturday, July 21st: Peploe Cartwright, Esq, in the chair. Mr. Doyle stated that certain alterations in the House of Industry would have to be made; and in order to effect these improvements at as small a cost as possible to the incorporated parishes, he suggested that six other parishes should be united to the present, the expense being thus spread over a larger number 120 


\section{CHARITABLE DONATIONS.}

of rate-payers. The proposal was not favourably entertained, as such a measure would have involved the immediate dissolution of the Oswestry Incorporation. A resolution was adopted at the meeting, "That in the absence of proper information and details, we are at present of opinion that it is not desirable to dissolve the Oswestry Incorporation." From that time to the present the Poor-Law Board exercise only a general authority over the Incorporation, whose powers, as defined by the Act of Parliament, with the exception just named, remain intact.

In 1853 various alterations, suggested by the Poor-Law Board, were made in the House, at an expense of $\$ 1500$. The average number of inmates in the Institution is $\mathbf{1 7 4}$. The number which the House can receive is limited by the Poor-Law Board to 300. The election of Directors is independent of the Board; they are nominated by the vestries of the several parishes, and appointed by the Board of Directors.

The present officers of the Institution are as follows:The Rev. J. Maude, Chairman; the Rev. E. W. O. Bridgman, Vice-Chairman; Mr. John Hughes, Clerk to the Directors; and Mr. R. Richards, Master. Relieving Officers :-For the Upper Division, comprising Oswestry Town and Parish, Llanyblodwel, townships of Llwyntidman and Treprenal, Llansilin, and Selattyn, Mr. Thomas Davies. For the Lower Division, consisting of Chirk, Saint Martins, Whittington, Ruyton, West Felton, Knockin, and Kinnerley, Mr. Joseph Rogers.

\section{CHARITABLE DONATIONS TO THE POOR.}

In the present age the good old-fashioned mode of bequeathing some portion of worldly substance for the education or relief of the poor is recognized by very few of our wealthier fellow-countrymen. The usual channels of relief to the poor and needy - the Poor-Law Union, the Night Asylum, the Good Samaritan Society, and other institutions of like class-are excellent in their way, and diffuse much 121 


\section{CHARITABLE DONATIONS.}

benefit and comfort among the aged and indigent; but still our ancient charities, especially our schools and alms. houses, whilst they secure to their recipients permanent, not precarious good, shed a brilliant lustre over the land, and denote the kind and benignant spirit of many of our ancestors. Would that the old benevolent English spirit were revived among us, and that all affluent men, who have possessed their money by inheritance, or obtained it by the force of their talents, or success in trade or commerce, would, among their testamentary bequests, never fail to "remember the poor." Then should we have comfortable asylums for many hoary-headed men and women, who, reduced by misfortune, or overwhelmed by the distressing calamities of life, have no place of quiet shelter-no resting-place in which to pass the residue of their days.

The following list of Charitable Donations, left for the benefit of the poor of Oswestry, shows that in days gone by, the weak were not overlooked by the strong, and that many, imbued with practical Christian benevolence, deemed it their duty to aid, not only the poor of their own days, but those also of succeeding generations. The only Alms-Houses in the town are those situated near the turnpike-gate in WillowStreet. They are six in number, and were left by Dame Ellen, widow of Sir Francis Eure. Mrs. Jane Owen, in 1732, bequeathed to the twelve poor persons ( women), inmates of the alms-houses, the sum of $18 \mathrm{~s}$. to be paid to them yearly, for ever, and also ordered her executor to charge her real and personal estate with the payment thereof. Mrs. M. Ormsby, by her will in 1805, requested her daughter (the present Mrs. Ormsby Gore), and those who should succeed her in the Porkington Estate, would pay "as she had done," the poor people in the alms-houses for ever. Mrs. Ormsby Gore regularly distributes $£ 3$ among the inmates on Christmas-Day, that being the sum her mother had previously given. The alms-houses are kept in good repair by Mrs. Ormsby Gore, and she selects the inmates. 
TABLE OF CHARITABLE DONATIONS.

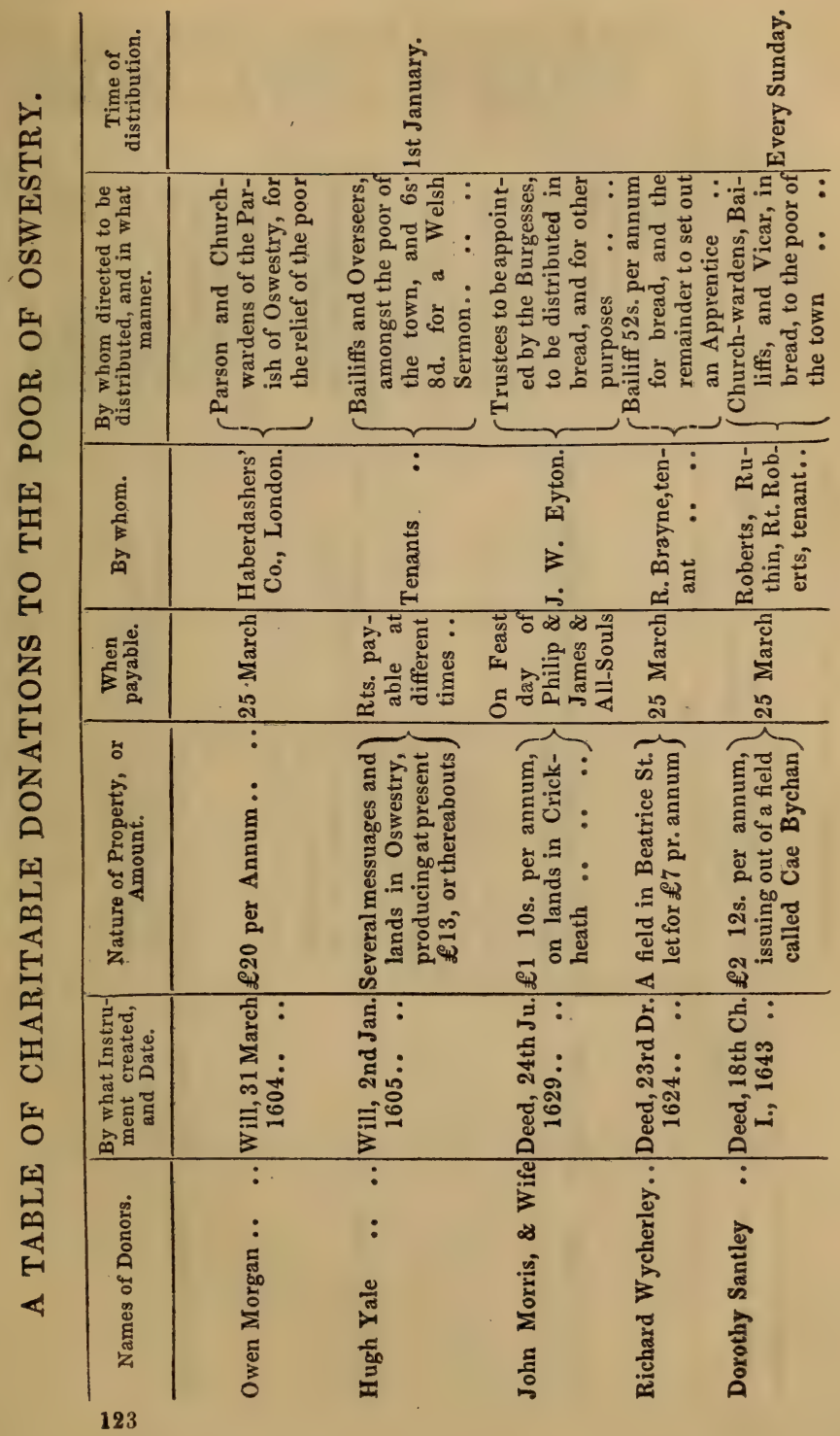




\section{TABLE OF CHARITABLE DONATIONS.}

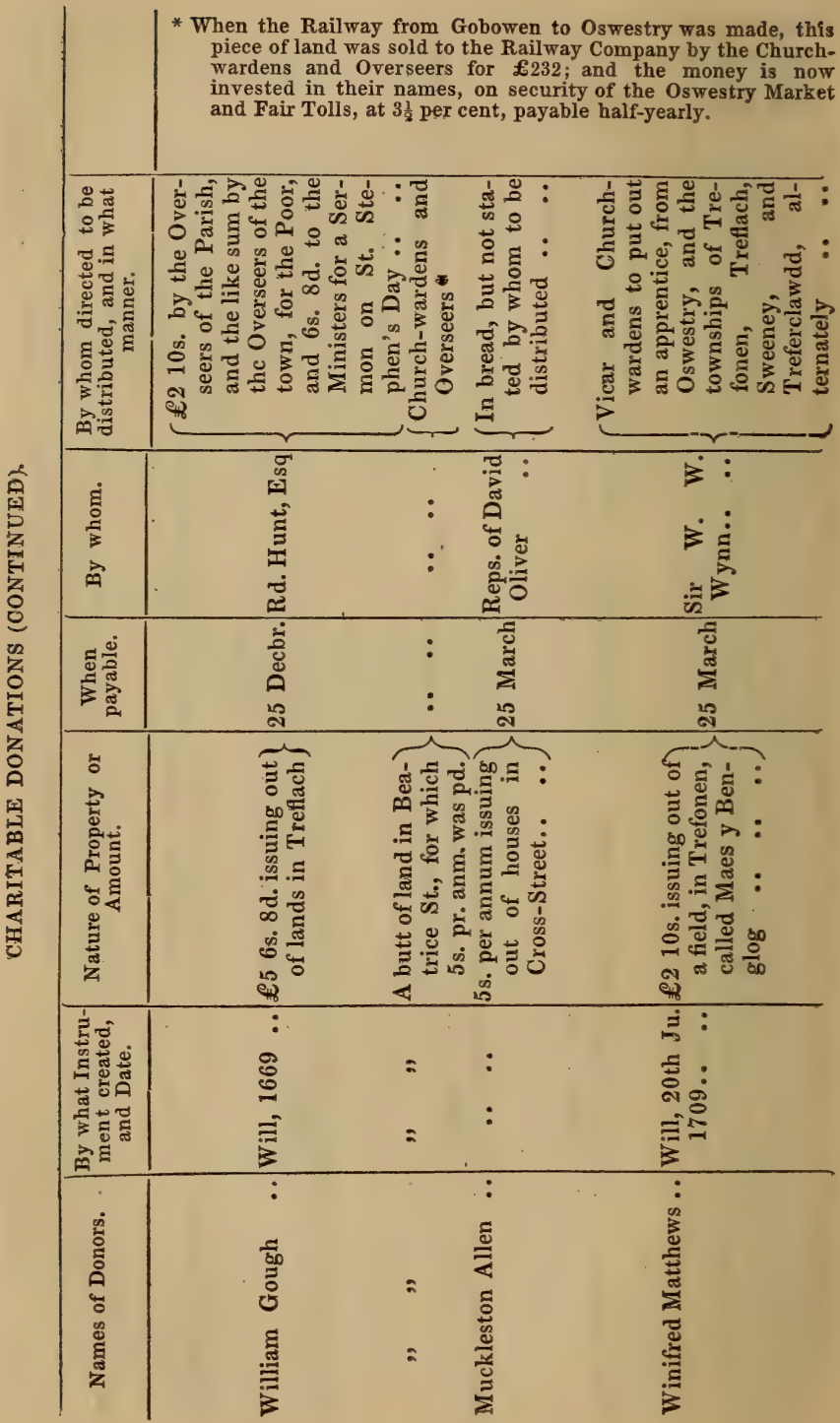


TABLE OF CHARITABLE DONATIONS.

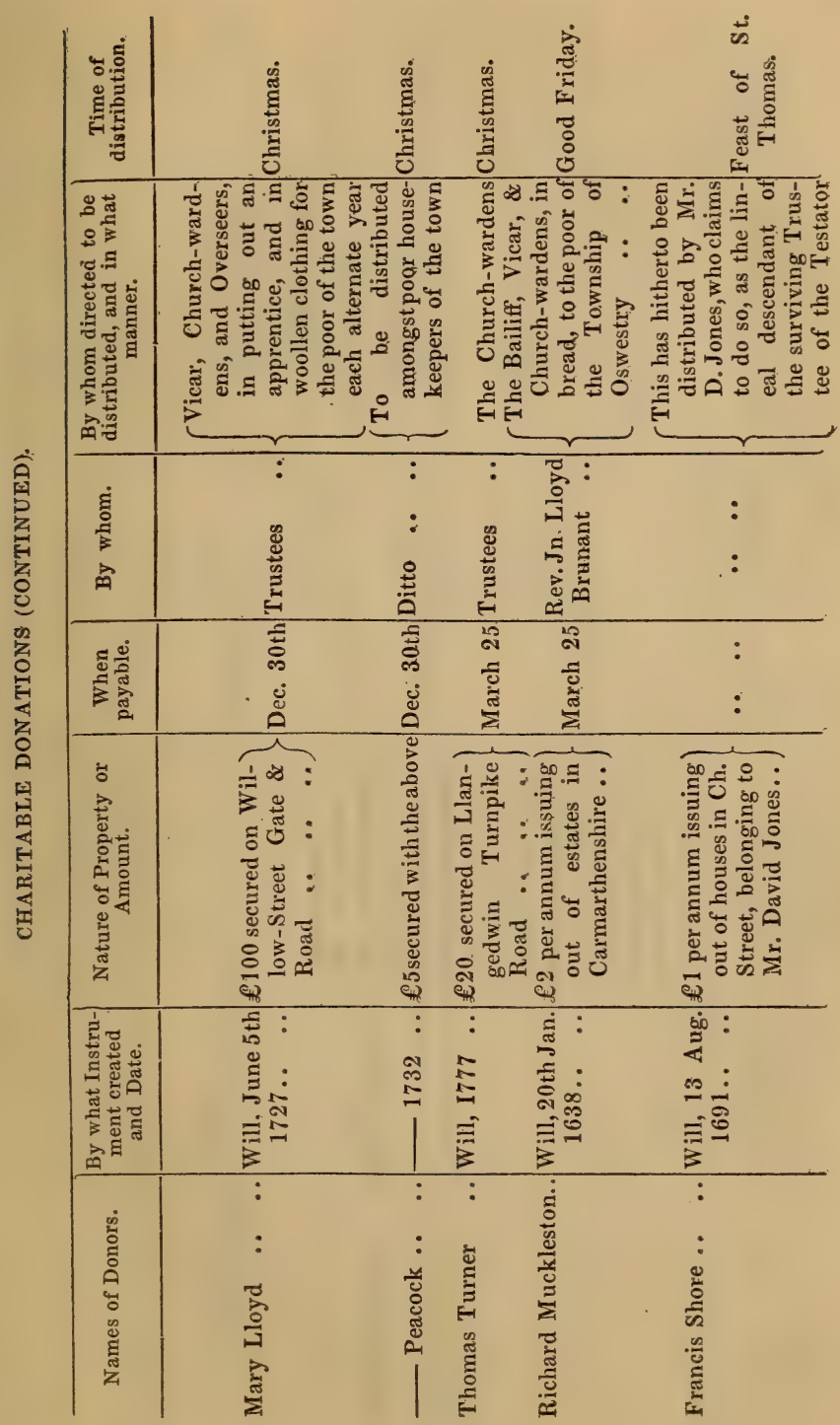

125 
TABLE OF CHARITABLE DONATIONS.

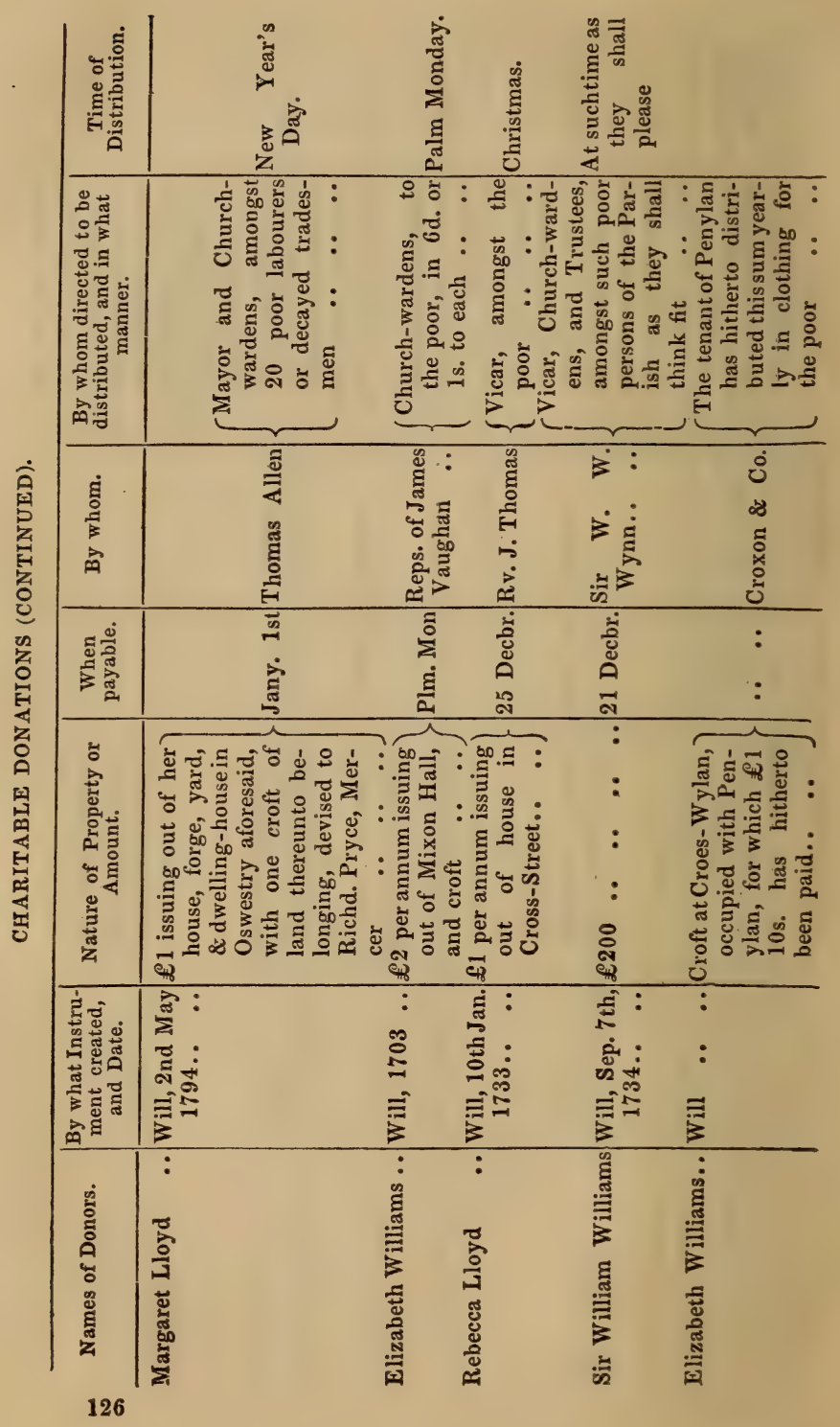


TABLE OF CHARITABLE DONATIONS.

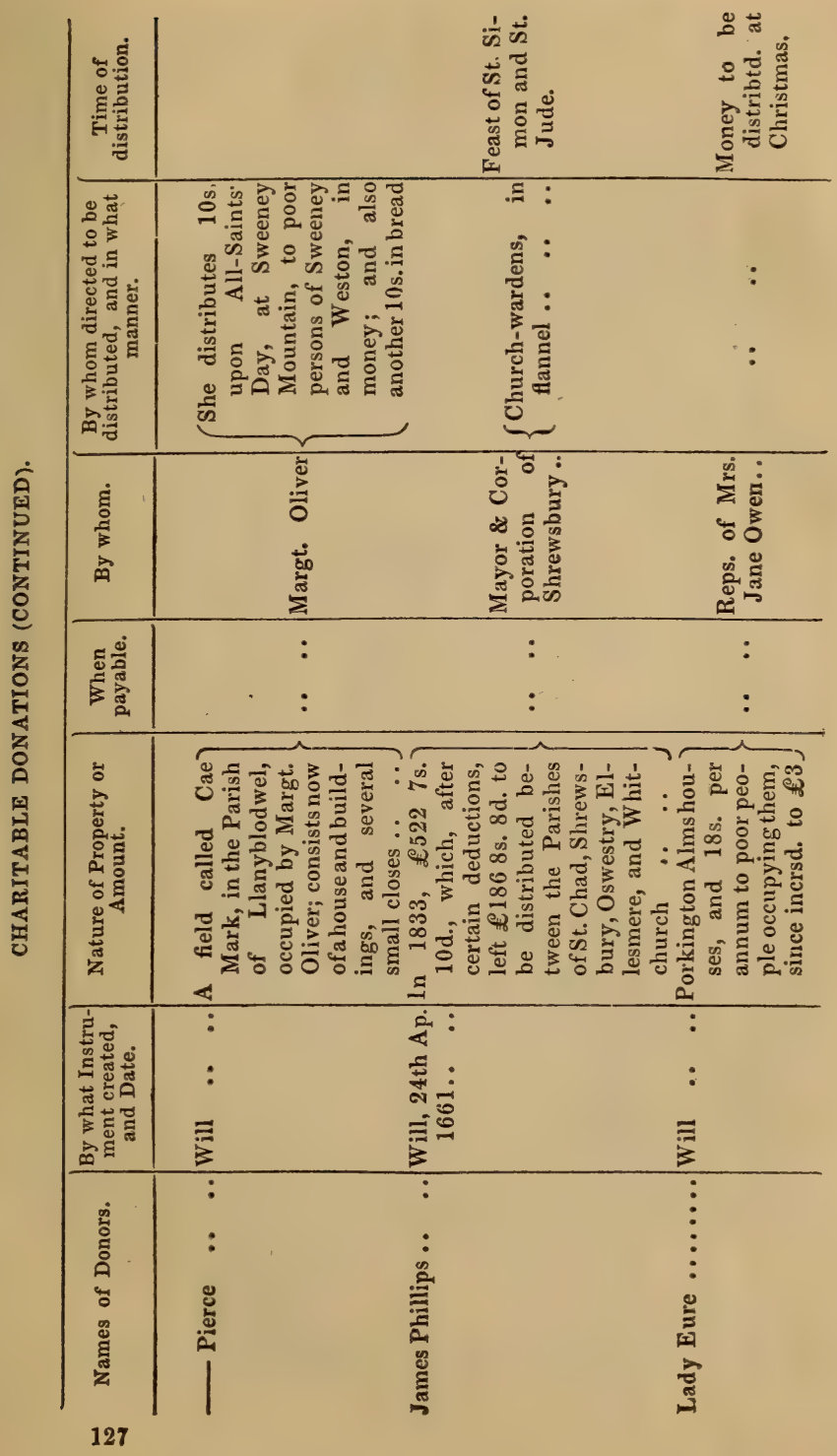


TABLE OF CHARITABLE DONATIONS.

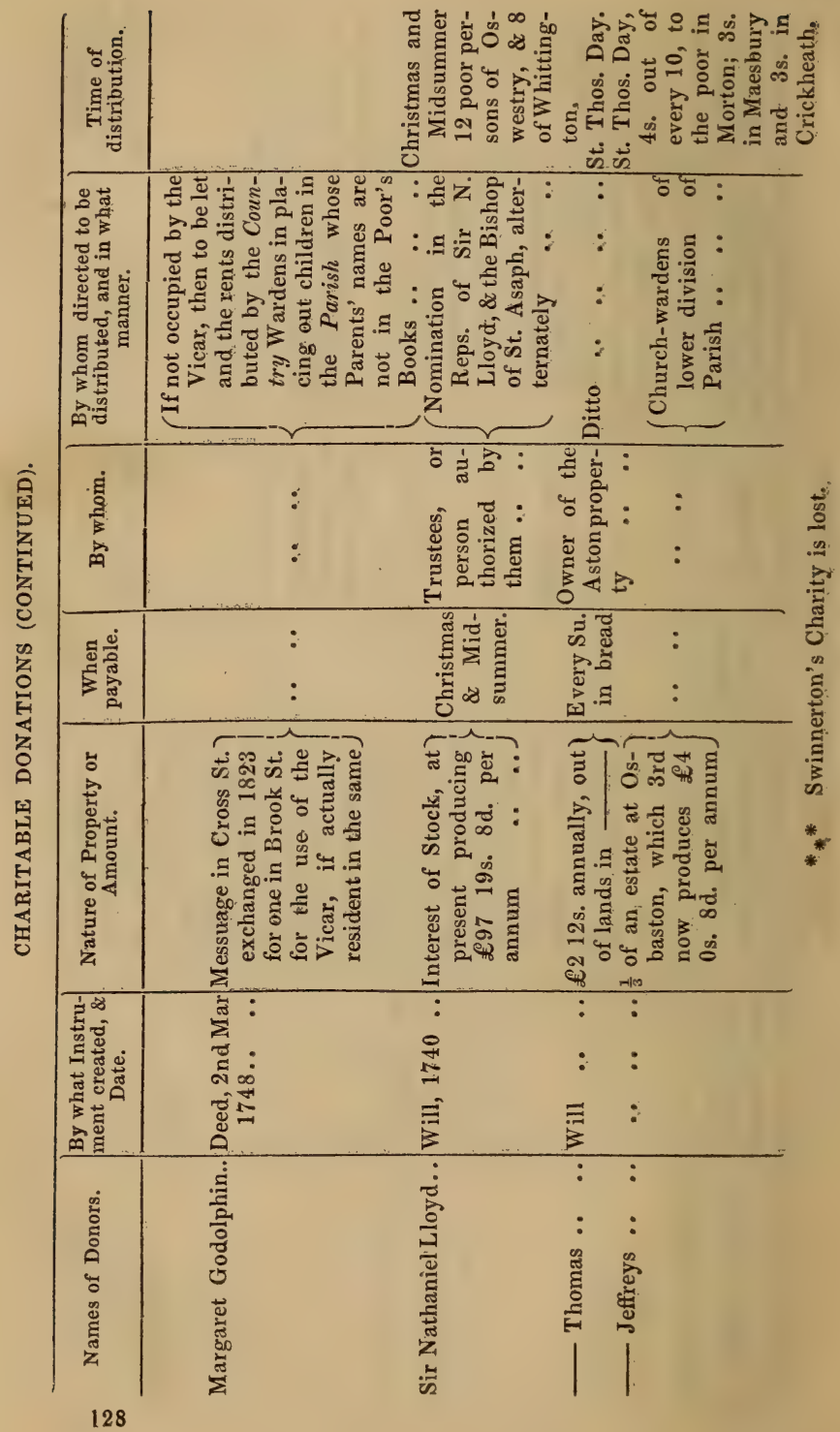




\section{BENEVOLENT INSTITUTIONS.}

\section{LIST OF CHARITIES FOR THE USE OF THE CHURCH. WARDENS, CONSISTING OF SUCH ONLY AS ARE PAID TO AND DISTRIBUTED BY THEM.}

\section{Charities relating to the Town only.}

Yale's; Morris's ; Witcherley's ; Sontley's ; Donor unknown, (Owen?) Land in Beatrice Street; Muckleston Allen's; Lloyd and Peacock's; Muckleston's (Poor of Oswestry) ; Margaret Lloyd's ; Elizabeth Williams's (Mixon Hall); Rebecca Lloyd's (Freeman).

Charities relating jointly to the Town and Parish.

Morgan's; Gough's; Winifred Matthews's; Turner's; Sir William Williams's.

Charities relating to the Parish only.

Elizabeth Williams's (Croft at Croes-Wylan); Jeffreys's.

\section{The SOCIETY For BETTERING the CONDITION OF THE POOR,}

Within the Hundred of Oswestry, was established in or about the year 1812, by the late Rev. C. A. A. Lloyd, Rector of Whittington, and the late Rev. G. N. K. Lloyd, Rector of Selattyn. The objects of the Society at its original institution were-the encouragement of schools for the education of the lower classes; the increase of the comforts of the poor in their dwellings, by the improvement of cottages ; the distribution of moral and religious books and tracts; the encouragement and promotion of friendly societies; the establishment of a bank for the poor, paying interest for small sums; and, finally, the distribution of rewards among the poor for extraordinary acts of industry.

During the progress of the Society very much has been done in the neighbourhood, through its instrumentality, with 


\section{BENEVOLENT INSTITUTIONS.}

regard to the above objects. Several schools were established soon after its commencement, and a vast number of moral and religious publications have been given as prizes, from time to time, to the best-informed children, and also as rewards for proficiency in writing, drawing, sewing, \&c. With respect to the improvement of cottages, the Society issued several small publications some years ago, directing the attention of owners of property to this very important social amelioration; some plans were also engraved, and rules printed, relative to the building of habitations for the poor. Through the influence of this institution some Friendly Societies were established, and also (which is well worthy of notice) a Savings' Bank for the poor, about four years before the present excellent institution commenced operations in conformity with an Act of Parliament passed on the subject. As soon as the Government Savings' Bank was opened, the funds of the former were transferred to it.

Subjoined are specimens of some of the prizes which were offered by the Society during the year 1854:-

No. 2.-To the Labouring Cottager who shall be found to occupy the best-furnished, neatest, and cleanest Cottage, together with the best-cultivated Garden, the same being not less than a quarter of an acre in extent:

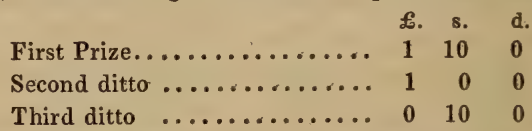

No. 5.-To the most deserving Widow, who under the greatest difficulties has supported herself by her own unassisted exertions:

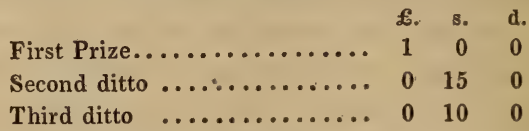

No. 8. - To the Cottager, or Farming Servant, who shall have accumulated most money in the Savings' Bank, the same to have arisen entirely from his or her own earnings :

\&. s. d.

First Prize.............. 2 0 . 0

Second ditto ............. 1000 


\section{FRIENDLY SOCIETIES.}

No recipients of parish relief are allowed to become candidates for any of the prizes.

It is to be regretted that the Society, since the loss of its benevolent founders, has been in a declining state; but it is to be hoped that an institution which has effected so much social and domestic comfort, and advanced the cause of morality and vital religion, will not, in this wealthy district, be allowed to expire for want of support. Franklin has well observed, that "more will be done for the happiness of the poor by inuring them to provide for themselves, than could be done by dividing all your estates among them." 'To establish principles of self-reliance among a people is to secure to them respectability and a manly independence of character.

\section{FRIENDLY SOCIETIES.}

There are several Friendly Societies in Oswestry, all of which are conducted with prudence and judgment, and are at present in a state of prosperity. The following is a list of these institutions:-

Sun Friendly Society, established 1765, consisting of 107 Members.

The Feathers Friendly Society, established 1830, consisting of 150 Members.

King Oswald Lodge of Odd Fellows, No. 603 Manchester Unity; established 1833, consisting of 153 Members. Held at Osburn's Hotel.

Philanthropic Lodge of ditto, No. 1637, established 1838, having 50 Members Held at the George Inn.

Duke of Cornwall Court of Foresters, No. 86, established 1840, consisting of 86 Members. Held at the Unicorn Inn. 


\section{Errlesingtiral}

\section{THE PARISH CHURCH.}

\section{9 . is beauty of architecture, externally or internally, yet,}

from its size and the massiveness of its ivy-mantled tower, has a venerable and somewhat imposing aspect. Girded on the west side by noble elm trees, and on the north by an avenue of limes, its tower presents on every side an object of much interest in the surrounding country. The eye even of the casual observer cannot fail to remark how much the fabric has suffered in former times, little probably of the original structure remaining. The different styles of architecture in the present building might enable the antiquary to decide with some probability when each particular part was restored. The only windows possessing any architectural beauty are those in St. Mary's chancel, and it is to be lamented that, when the south side of the chancel was restored some years ago, the new windows were not made uniform with these. At present nothing can be more incongruous than the different styles which present themselves on every side.

There are perhaps few churches, in a parish so large and important as Oswestry, which contain so meagre a collection of records relating to it. Doubtless many of the books belonging to it were lost during the disturbed times which ended in the establishment of the Commonwealth. The old Vicarage House is supposed to liave been burnt down, either at this time or in some former incursions of the Welsh. It stood on the north side of the church-yard, and when this site 132 


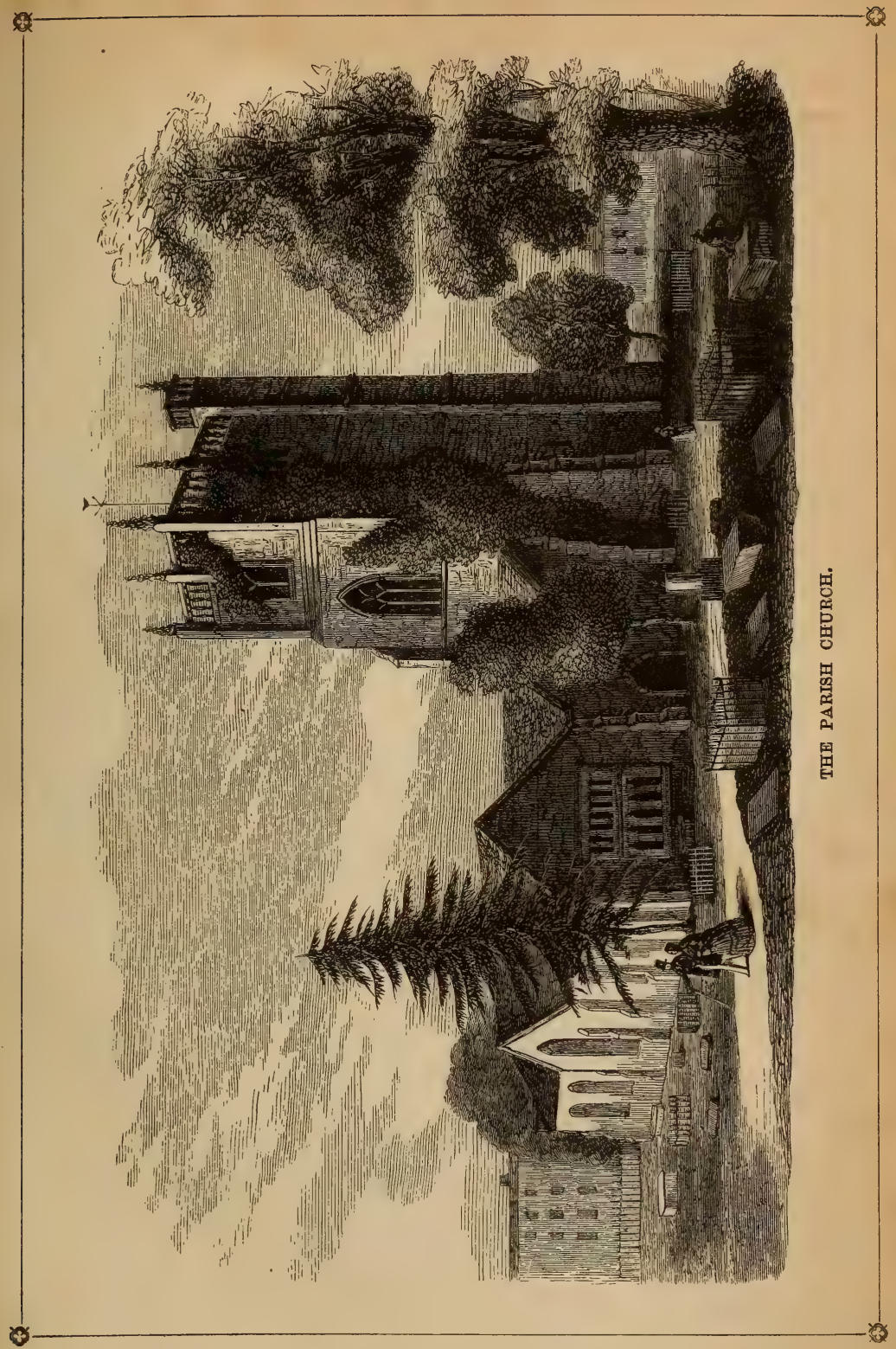



was exchanged with the late Mr. Lloyd, of Swan Hill, by the then Vicar, for what is now the New Church-Yard, and which then became the Vicar's Croft, the row of trees forming the north side of the avenue, though separated by a wall from the church-yard, was expressly reserved as belonging to the church; and the present owner of that property has no right to cut down, or even to lop, the trees; whilst the Vicar has at all times power to enter upon the premises to plant new trees, if any of the present ones should be blown down or injured. The croft which became the Vicar's, by the above exchange with Mr. Lloyd, was again exchanged by the late Lord Powis for what is now the Vicar's land in Salop Road, and Lord Powis then gave the croft thus obtained as a free gift to the parish for a new Burial-ground. This, however, is already nearly filled, and as the Old Church-yard ought unquestionably to be shut up and disused for burials, another and a larger Burial-ground is much needed.

In the year 1748 Mrs. Margaret Godolphin endeavoured to remedy the loss of the old Vicarage House, by leaving to the Vicar and his successors for the time being a small tenement at the back of Cross-Street, as a residence, but coupled with this proviso, that if the Vicar should not occupy it himself, then it was to be let by the Churchwardens, and the rent appropriated in putting out apprentices from amongst the poor. It does not appear that the house so given by Mrs. Godolphin was ever occupied by any Vicar, and it consequently fell at once under the second provision of the will, and became a sort of Poor-house for the town. This continued till the year 1823, when the house was exchanged for more desirable premises in Brook-Street, which were for many years occupied by the present Vicar; but in consequence of his non-residence, through ill health, the property has been given up by him, and has once more reverted to the second purpose of the charity. 


\section{THE PARISH CHURCH,}

The antiquity of the church, as we have already intimated, is not clearly defined in any of the books relating to the history of the county. In the records of the Augmentation Office the following minutes are made in reference to the Rectory and Vicarage of Oswestry:- "The Church of Oswestry is doubtless of great antiquity. There was certainly a vicarage here antecedent to the formation of the Valor by Pope Nicholas IV., A.D. 1291; for in the record, the original of which is preserved in the Exchequer, Oswestry is thus recorded:-

"ST. ASAPH,

SPIRITUALITIES.

DEANERY OF MARCHIA.

Church of Oswalstro:

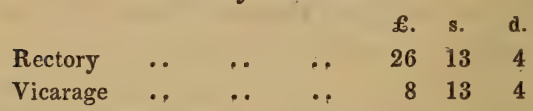

"From this it is evident that the vicarial endowment of Oswestry must be of a date prior to 1291 ; and in all probability, therefore, so ancient as to preclude the expectation of its being extant.

"The Church of Oswestry was, in early times, given to the Monastery of Shrewsbury, and afterwards appropriated thereto, and the rectory and tithes converted to the uses of the said monastery. They continued to belong to the monastery until, as one of the great religious houses, Shrewsbury was, by force of the statute of 31 Henry VIII., dissolved, when its tithes and other possessions came into the hands of the crown." The tithes of Oswestry afterwards became the property of the Earl of Arundel, Lord of Oswestry, and then of the Earl of Powis, who sold them in 1819 (excepting the liberties of Oswestry town and Middleton township) to Mr. W. Lloyd, of Aston, Mr. T. N. Parker, of Sweeney, the Hon. T. Kenyon, of Pradoe, and others.

Within the tower of the church are eight silver-toned bells, whose joyous peals on occasions of festivity give hilarity to 134 


\section{THE PARISH CHURCH.}

all who hear them. A new clock was substituted for an old one in 1836, the cost of which was paid by public subscription.

The church is dedicated to St. Mary. A new organ was erected by subscription in 1812; and the organist, by the adoption of effective sacred music, and the choir, by its able execution of the beautiful psalmody selected, contribute much to the solemnity and effect of public worship in this venerable church. The present Organist is Mr. Edward Eyeley. It is stated that the old organ, a fine-toned instrument, is fixed in one of the metropolitan churches.

The interior of the church, especially on a Sabbath morning, when a numerous congregation generally assembles, presents a most delightful spectacle. The place where, for ages past, divine worship has been held, and the footsteps of grandsires and great-grandsires have led them to bow before the "throne of the heavenly grace," cannot fail to exhibit an affecting scene to all who understand the frailty and brevity of human life.

The church was enlarged and beautified in 1807 ; and in 1831 a new entrance door was completed at the east or chancel end. A great improvement in the interior, both as to comfort and effect, would still be added, were a new set of pews erected. Many of the present pews are most unsightly and inconvenient. A new set, formed on the most approved principle of church seat-accommodation, would be acceptable to all pew-holders, giving neatness and adding comfort within the fabric which every member of the congregation would heartily approve. The inhabitants of the parish have accomplished much, in the way of public improvement, within the last few years; and the alterations we have now suggested would be a crowning point to their spirited exertions for the benefit and honour of the town. The altar-piece might be removed, and a more suitable one introduced, at a trifling expense.

The Communion Plate belonging to the church consists of the following articles:-A silver cup, bearing the inscription, 


\section{THE PARISH CHURCH.}

"Ex Dono Dauidi Edwards"; another cup, dated 1575, the gift of "Richard Stanni," "Elder Mercer"; a silver flagon, the letters "I.H.S." engraved thereon, with the inscription, "Given for the use of the Holy Communion, in the Parish Church of Oswestry, 1707"; and two silver salvers, the gift of Mrs. Elizabeth Roderick.

The CHURCH-YARD is no ordinary resting-spot for the dead. As we have already said, it would be well now to close it as a place of sepulture. Sanitary motives would urge this change; and the feelings of those whose departed relatives or friends are about to be consigned to the grave should be religiously deferred to. The Church-yard may soon be surrounded by human dwellings, and then the newly-laid dead will lie amidst the busy living.

Its beautiful avenue, rendered still more pleasant in spring, summer, and autumn, by the lofty row of lime-trees which separates it from the space appropriated to the tenements of the dead, might be made still more impressive in character, were a neat lattice-work constructed, extending from tree to

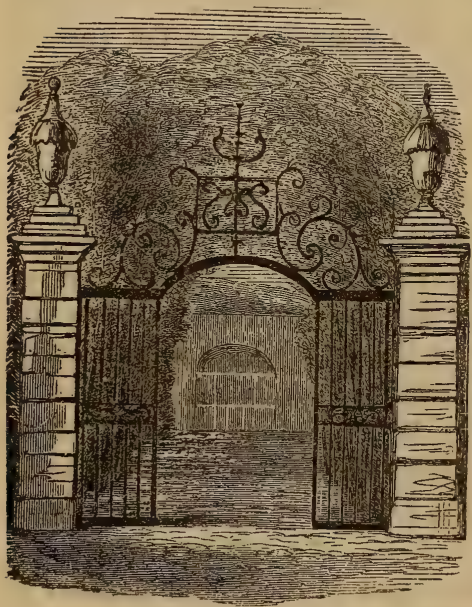

THE CHURCH GATE AND AVEYUR. tree, to mark the line of demarcation between the avenue and church-yard more distinctly. A sketch of the Avenue, with the Alcove at the west end, is here given, as well as the florid, chastely-designed Gate leading to it from Church - Street. This

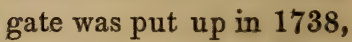
at the expence of the parish. Country churchyards are always deeply interesting to the contemplative and thoughtful; and Gray's truthful 136 


\section{THE PARISH CHURCH.}

and pathetic Elegy, which appeals so powerfully to the best feelings of our nature, has invested them, however rude and humble, with an affecting character that touches the hearts even of the most indifferent. Oswestry Church-Yard, with its aged elms of more than a century's growth; its sombre yews ; its stately tombs and humble graves for patrician and plebeian dust, "the rich and the poor meeting together," is a scene conveying monitory lessons to all who will seriously read them. Among the tombs are several, bearing appropriate inscriptions, containing the ashes of French prisoners of war, who died in Oswestry on their parole, between the years 1811 and 1814 . The ancient entrance to the Church-yard from Upper BrookStreet, through the Gridde $\mathrm{G}_{\mathrm{Ate}}$, is a curious relic of byegone times. Formerly, on occasions of burial from the south

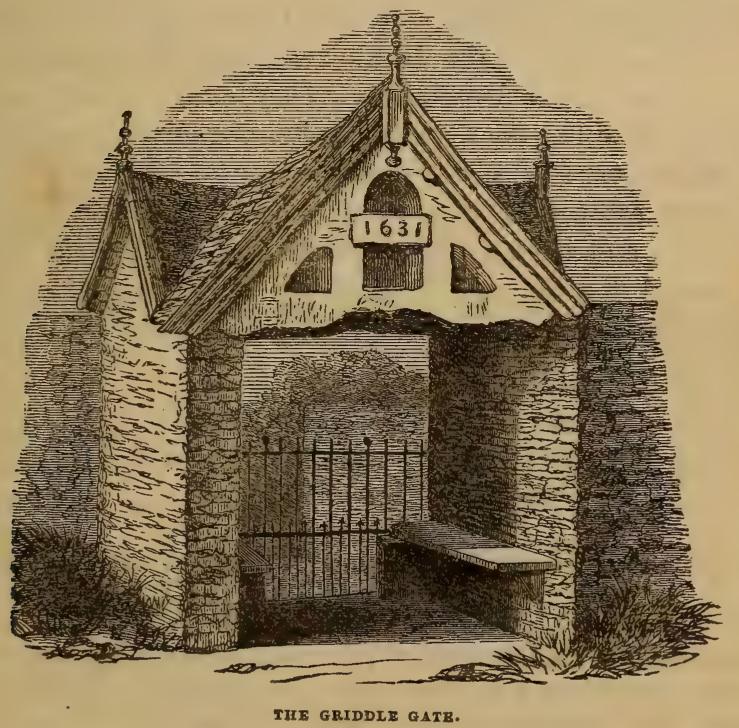

side of the town, the coffin of a deceased party was placed temporarily on a bier within the porch of the Griddle Gate, 


\section{THE PARISH CHURCH.}

and thence conveyed to the church. It will be seen from the engraving we give of this Gate that it was erected in 1631 .

We may here state that the elm-trees in the church-yard were planted at the expense of the Rev. Thomas Owen, when Vicar of the Parish, between the years 1707 and 1713.

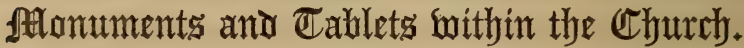

How valuable are Monumental Inscriptions, when they are the records of truth, and affectionate tributes to departed worth! The tablets on our church walls are silent, but often effective monitors, reviving drooping spirits, recalling scenes of sublunary enjoyments, transient as the stay of the dew-drop in the sun, and suggesting the brevity and uncertainty of human existence. Within Oswestry Church, as well as in its grave-yard, most of the Monuments and Inscriptions are simple, chaste, and impressive. They either plainly mark the spot where lies the departed body, or touchingly express the natural grief of surviving relatives or friends. Whilst wandering among the habitations of the dead, and viewing, with "slow and solemn steps," the houses, for rich and poor, "appointed for all men living," we can sympathize with Salopia's own sweet poet, in his beautiful apostrophe:

\footnotetext{
"Thou, sainted Memory, art mine, And smiling Hope, of birth divine, Ev'n now I feel your mingled pow'r, Ev'n in this solitary hour."
}

On the north wall, within the church, is an ancient monument exhibiting a male and female kneeling.

"In memory of Mr. HUGH YALE, alderman of this town, and DoROTHY his wife, daughter of Roger Roden, Esq., of Burton, in the county of Denbigh, whose bodies are interred within ye chancel of this church, commonly called St. Mary's, before its demolition in the late wars, anno 1616. They gave to ye poor of this town the yearly interest and benefice of one hundred pounds, to continue for ever ; besides other good acts of charity." 138 


\section{MONUMENTS WITHIN THE CHURCH.}

\section{Beneath this inscription:}

"Underneath are interred the remains of MARGARET, the wife of David Yale, Esq., daughter and heiress of Edward Morris, of Cae-mor, Gent. She departed this life, the 20th day of December, 1754, aged 66. Also lye the remains of DAvid YALE, Esq., who dy'd January the 29th, 1763, aged 81. This was erected by her son, John Yale, of Plas yn Yale, Clerk."

In 1721 died Edward Yale. There is a monument to him in Wrexham Church, with the following inscription:-

"Born in America, and in Europe bred,

In Africa travell'd, and in Asia wed,-

Where long he liv'd and thriv'd-in London died."

\section{On marble tablets on the same side:}

"Near this small monument lie the remains of Mrs. MARY Griffiths, the wife of William Griffiths, Gent., one of the aldermen of this corporation: she died on the 9th day of August, 1774, in the 70th year of her age. Likewise the remains of the said WrLliam Griffiths, who died the 14th day of November, 1791 , in the 81 st year of his age."

"Sacred to the memory of Elizaветн, the beloved wife of John Jones, Esq., of Brook Street, who departed this life the 2nd of February, 1835, aged 68. Also to the memory of the above-named JoHN Jones, who departed this life the 8 th of June, 1846, aged 86."

"VAUGHAN BarRetT, Esq., died 17th October, 1772, aged-years; MARY, relict of Vaughan Barrett; Esq., daughter of Thomas Kynaston, Esq., of Maesbury Hall, in the county of Salop, died 28th of May, 1779, aged-years; ELIZAвEтH, daughter of Vaughan and Mary Barrett, died 6th March, 1792, aged 58 years; LETrTiA, daughter of Vaughan and Mary Barrett, died 25th of March, 1803, aged 71 years. This testimony of affection and regard is erected to their memory by Edward Disbrowe, Esq., of Walton-upon-Trent, in the county of Derby."

"In memory of Elizabeth Venables, who died July, 1772, aged 39; Sarah Venables, who died June, 1807, aged 70; Margaret Venables, who died June, 1814, aged 80. Their remains are interred in an adjacent vault. They lived virtuously, and 'all died in faith,' in stedfast hope of a blessed resurrection."

"Likewise in memory of MARY ASHBURN, sister of the above-named, who died October 14th, 1817, aged 81, beloved and lamented." 


\section{MONUMENTS WITHIN THE CHURCH.}

On mural monuments on the north side of the chancel:

"M. S. RICHARDUS MAURICE, Arm. Ad pedem Columnæ huic Marm. oppositæ Exuvias Mortales Uxoris Alicı Æ, Filiæ Thomæ Carpenter, De Home, Com. Herefordiæ, Arm., cum unica ex eadem Filia Anna, tumulavit, September 4, A. D. 1700, Ætat. 22. Et MARgarete itidem, Secundis illi Nuptiis conjunctæ, Filiæ Johannis Price, A. M., ex qua Unum suscepit Filium, Johannem, cum Matre placide dormientem. Denat, September 4, A. D. 1716, Ætat. 32. In Uxorum et Liberorum Memoriam, H. M. R. MAURICE, P, C., in eodem Tumulo et suos aliquando Cineres depositurus, Æterna Requie fruiturus, si erga Deum Pietas, erga Pauperes Benignitas, erga Omnes summa Benevolentia illam Requiem afferre valeant. Obiit Primo die Junii, An. Salutis 1749, et suæ Ætatis 84."

"MDCCCXII. In memory of LEwis Jones, Esq., for fourteen years town-clerk of Oswestry: he died June 5 th, in the 56 th year of his age. This tablet was erected by the corporation of this town, in token of their affectionate remembrance of a man, who was remarkable for his knowledge of the laws of his country, and for his readiness in imparting that knowledge, with a view to prevent litigation among his neighbours."

"To the memory of ErizaBETH, the wife of Mr. Lewis Jones, who died 26 th of September, 1801, in the 38th year of her age. This small tribute of affectionate regard, as a testimony of her worth, and an expression of his own deep regret, is placed by her surviving husband."

"Sacred to the memory of Captain RoBert WATKIN LLoYd, of majorgeneral Gwynne's regiment of cavalry, only son of Robert Lloyd, Esq., of Swan Hill, aged 17. He fell a victim to the yellow fever, on the 26 th of June, 1794, at Port au Prince, in Saint Domingo, having survived the capture of that place. In him were united a mind firm and vigorous; a disposition kind and benevolent; manners engaging and mild, giving promise of a character which might one day have added lustre to his profession; have adorned the circle of polished society, and have sweetened the enjoyments of domestic life." "Sacred also to the memory of ROBERT LLoYD, Esq., of Swan Hill, father of the above-named Robert Watkin Lloyd, who departed this life on the 3rd day of October, 1803, aged 58. By that event, his family lost an affectionate husband and father; the. county an upright magistrate; and the public an amiable man."

A monument at the north end of the chancel:

"Robert Poweli Lloyd, son of Robert Lloyd, of Swan Hill, Esq., 140 


\section{MONUMENTS WITHIN THE CHURCH.}

by Sarah, his second wife, died 11th March, Anno 1769, and was interred in the vault beneath, aged 5 years. SARAH, mother of the above R. P. Lloyd, died 19th of August, 1790, aged 59 years; also Robert LLOYD, Esq., the father, died 5th of April, 1793, aged 72 years."

\section{A neat tablet at the same end:}

"Sacred to the memory of Thomas TrEvor, clerk, M. A., son of Roger Trevor, of Bodynfol, in the county of Montgomery, Esq., Vicar of this parish 50 , and of Ruabon, 15 years; chaplain to Sir W. Williams Wynne, baronet; and one of his Majesty's justices of the peace for the counties of Salop and Denbigh, who died the 29 th of February, 1784, aged 76. Of manners unaffected, he performed the service of the church with a peculiar grace; and by a propriety of elocution, attracted the attention, and raised the devotion of his hearers. He was an active and upright magistrate, tender husband, kind relation, and steady friend. He married twice-first, Elizabeth, daughter of Edward Maurice, of Trefedrhyd, in the county of Montgomery, Esq., 11th June, 1762 ; afterwards, Anne, daughter of Gabriel Wynne, of Dolarddyn, Esq., and relict of George Robinson, of Brithdir, Esq., both in the county of Montgomery, who survived."

\section{On tablets near the communion table:}

"Sacred to the memory of the Rev. TuRnER EDwards, L. L. B., Vicar of this parish, and of Llansilin, in the county of Denbigh ; rural dean of Marchia, in the diocese of St. Asaph; and one of his Majesty's justices of the peace for the county of Salop: he departed this life on the 10th of January, 1803, aged 44, leaving an afflicted widow, with five children, to deplore his untimely loss. Also underneath lie the remains of SARAH, relict of the above Rev. Turner Edwards, and second daughter of the late William Birch Basnett, Esq.; she departed this life on the 16th December, 1814, aged 52. This monument, a slender token of duty and affection, was erected by their surviving children, Turner, John, William, James, and Mary Anne."

"Sacred to the memory of the Reverend Joseph Venables, L. L. B., who was born 31st August, 1726, and died 14th August 1810. As a minister of the Gospel, he illustrated his precepts by his example, by his piety, benevolence, and general character as a man. To his relations, his affection and kindness were unbounded; for society, his friendship was ardent and sincere; and when his Creator called him to another and a better world, he closed a long and well-spent life, respected and lamented.". 


\section{A tablet near the communion table:}

"To the memory of Thomas KYNaston, of Maesbury, Esq., who died in 1710 , aged 33 ; also of three of his children, and five grand-children."

On a plain slab near the town door:

"Sweeney Vault.-Underneath lie the remains of EDWARD Browne, Esq., who departed this life 22nd of February, 1794, aged 80."

\section{On a neat marble tablet near the above :}

"Edvardo Browne, de Oswestry, in comitatu Salopiensi, armigero, qui vixit ann. 80. Decessit 8 Calend. Mart., Anno sacro 1794. Sara, conjux Thomæ Netherton Parker, haeres ejus, ex asse, pio gratoque animo in avunculum optime de se meritum, hoc monumentum faciendum curavit."

\section{Mural monuments near the above:}

"M. S. Jacobi Donne, S. T. P., Ecclesiæ Blodwell, in agro Salopiensi, Vicarii, qui, dum Scholæ Oswestriensi per annos 36 præfuit, quid sit verus ingenuarum artium finis, quid erga Deum patriamque pietas, quid strenua illa honestas, nominis Britannici prisca propugnatrix, præceptis, exemplo, tota vitæ ratione, pro virili edocuit. Quanta denique Religionis Christianæ vis, ipse jam tandem placida senectute degens otium, et ad extremam vitæ horam sacris literis officiisque deditus sanctioribus, sibi suisque feliciter demonstravit. Hoc monumentum poni curaverunt, qui, disciplina pueri tam honesta instituti, provectioribus jam annis venerandi illius capitis testari volunt desiderium."

"Sacred to the memory of Charles Penson, a friend and instructor of the poor, and a lover of all who loved the Lord Jesus Christ. He died November 26 th, 1836, aged 40 years. Although nearly blind, he was an honoured instrument in God's hand in turning many from darkness to light. His life was spent in an active course of self-denying Christian benevolence, yet ever counting himself an unprofitable servant. In life and in death he had but one ground of hope, the mercy of God in Christ Jesus. Near this place he long sat as a Teacher in the Sunday School, labouring to make known to others that Saviour whom he had found so precious to his own soul. 'His faith follow, considering the end of his conversation; Jesus Christ, the same yesterday, to-day, and for ever.' Heb. xiii, 7, 8. This tablet is erected to his memory by many who esteemed him very highly in love, for his work's sake." 


\section{MONUMENTS IN THE CHURCH-YARD.}

Tablet on a pillar in the chancel:

"Sacred to the memory of RICHARD PRICE, surgeon, one of the senior aldermen of this town, obt. 26th September, 1790, æt. 68. Also to the memory of Susanna, wife of Nathaniel Price, Esq., who departed this life February 23rd, 1844, aged 67 years. Also of Nathaniel Price, Esq., who departed this life May 22nd, 1847, aged 67 years. This tablet was erected as a tribute of affection by Harriet, daughter of Susanna and Nathaniel Price."

A brass plate near the organ gallery steps:

"Mary, wife of Humphrey Mostyn, Esq., died September 3rd, 1781, aged 60. Also of HuMPhreY, youngest son of William Mostyn, Esq., of Brongwyn, Montgomeryshire, died 12th of January, 1786, aged 60."

Scroll, surmounted by military insignia, on south-east wall:

"Sacred to the memory of Captain OWEn ARThur ORMSBy Gore, of the 43rd Light Infantry, third son of William Ormsby Gore, Esq., M. P., of Porkington, who fell in action with the Caffres, at the head of his Company, on the 6th of April, 1852, at 'Antas Cave,' British Caffraria. This monument was erected by his brother officers, as a mark of their affectionate regard."

Arms-Motto, "In hoc signo vinces."

Tablet, surmounted by an urn:

"Sacred to the memory of Henry Pinson Tozer Aubrey, Esq., of Broom Hall, in this Parish, who died deeply and deservedly lamented, September 30 th, 1848 , aged $69 . "$

"The memory of the just is blessed."

\section{ftomuments in the Churcly=nario.}

We select the following from various parts of the Churchyard :-

"Sacred to the memory of SAMUel LeACH, Esq., Llanforda Issa, and an alderman of the corporation of this town, who departed this life November 4th, 1833, aged 67 years."

"Sacred to the memory of MARY, relict of the late Samuel Leach, who departed this life February 25 th, 1838, aged 60 years." 


\section{MONUMENTS IN THE CHURCH-YARD.}

"To the memory of the Rev. JoHN SHeil, Incumbent of Cannock, Staffordshire, who died at Oswestry, September 24th, 1841, aged 61. This tribute of esteem and regard, is erected by his former pupils-Arthur Viscount Dungannon, of Brynkinalt, and the Rev. John Parker, Vicar of Blodwel."

"Thomas Hunt, died February 17 th, 1831, aged 69 years. Susanna, widow of the said Thomas Hunt, died August 21st, 1844, aged 82 years."

"Sacred to the memory of Francis CampbelL, Esq., an alderman of the corporation of this borough, who died September 26th, 1841, aged 73. Also, Mary Campbell, relict of the above, who died April 30th, 1845, aged 78."

"Sacred to the memory of ElizaBETH, daughter of the late Thomas Peate, Esq., of Preeshenlle, who died November 6th, 1841, aged 67 years."

"Sacred to the memory of JoHN TomLEY, Gent., late of Middleton, in this parish, who died August 25th, 1808, aged 74 years."

"Sacred to the memory of Eurzabeth, the beloved wife of John Jones, Esq., who departed this life, the 2nd February, 1835, aged 68. Also to the memory of the above-named John Jones, who departed this life the 8 th June, 1846, aged 86."

"Sacred to the memory of RANDLE Jones, son of John and Elizabeth Jones, who departed this life April 10th, 1821, aged 23 years."

"Sacred to the memory of MARY, youngest daughter of John and Elizabeth Jones, who departed this life January 27 th, 1833, aged 31 years."

"Sacred to the memory of Емма, the beloved wife of John Jones, jun. Esq., who died June 19th, 1834, aged 37."

"Sacred to the memory of ElizA, eldest daughter of John and Elizabeth Jones, who departed this life the 24th May, 1854, aged 61 years."

"Sacred to the memory of Skinner Hancox, Esq., late colonel of the 7 th Dragoon Guards, who departed this life January 27 th, 1843, aged 55." "If Thou, Lord, shouldest mark iniquities, O Lord, who shall stand? But there is forgiveness with Thee, that thou mayest be feared."

Psalm. $\operatorname{cxxx}: 3,4$.

"Sacred to the memory of General JoHn DEspard, late colonel of the 5 th West India regiment, who died at Swanhill, September 3rd, 1829, in the 85 th year of his age, after having honorably served his country for 70 years. Also of HARRIET ANNE, sister of the late Sir Thomas Dalrymple Hesketh, Bart., of Rufford Hall, Lancashire, and relict of the above General John Despard. She died at Brighton, May 14th, 1848, aged 76 years." 


\section{MONUMENTS IN THE CHURCH-YARD.}

"Conway Longueville, eldest daughter of Thomas Longueville Longueville and Anne, his wife, died 17th March, 1854, aged 14 years."

"Charles Henry Longueville, their youngest son, died 30th June, 1854 , aged 6 years."

"In memory of JoHn Croxon, alderman of this town, who died March 21st, 1803, aged 66; and of ALICE, his wife, daughter of Richard and Alice Jones. She died July the 19th, 1824, aged 87. Elizabeth, wife of Samuel Tudor, of Shrewsbury, and daughter of the above-named John and Alice Croxon, died January the $24 \mathrm{th}, 1811$, aged $36 . "$

"Sacred also to the memory of RICHARD CRoxon, of this town, eldest son of the said John and Alice Croxon, who died the 31st July, 1838, aged 70."

"Here lie the remains of Alexander Kyffin, who died August 10th, 1766, aged 51. Also of MARGARET, his wife, who died December 20th, 1815, aged 73,"

"In memory of SARAH, wife of Charles Osburn, who died February 11th, 1851, aged 66. Also of the above-named Charles Osburn, who died February 16th, 1851, aged 66."

"Sacred to the memory of William Price, who died November 4th, 1847, aged 70 years. Also of JANE, widow of the said William Price, who died April 10th, 1848, aged 68 years."

"Sacred to the memory of Charles Thomas Jones, late of this Town, Banker, who died 16 th October, 1847, aged 70 years."

"Sacred to the memory of RoBERT EDWARDs, late of the Queen's Head Inn, in this Town, who died February 2nd, 1843, aged 62. And of SARAH, his beloved wife, who died April 7th, 1843, aged 59. Also of Tномаs, third son of the above Robert and Sarah Edwards, who died June 20th, 1843, aged 27 years. Life, how short, how uncertain! Look, O! look on this monument, ye gay and careless; attend to these dates, and boast no more of to-morrow.

'Father, thy chastening hand we own,

And bow submission to Thy rod;

That must be wise which Thou hast done,

It must be kind, for Thou art God." " 


\section{MONUMENTS IN THE CHURCH-YARD.}

"In memory of RoBERT, second son of Robert and Sarah Edwards, who died December 1st, 1808, aged one year. Also of RoBERT, their fourth son, who died January 20th, 1818, aged 6 months. Also of MARTHA, their fourth daughter, who died March 8th, 1823, aged 11 months. Also of Sophra, their fifth daughter, who died May 15th, 1824, aged 4 months. Also of ROBERT EDWARDS, grandfather of the above infants, who died May 10th, 1837, aged 84."

"Sacred to the memory of JosepH, fifth son of Robert and Sarah Edwards, who died May 2nd, 1851, aged 32."

"In a vault beneath are deposited the remains of William Jones, late Ironmonger, of this town, who died December 28th, 1827, in the 71st year of his age. Also the remains of ELIzABETH JonES, relict of the above, who died April 12th, 1843, aged 81."

"THомAs, youngest son of William and Elizabeth Jones, died June $28 \mathrm{th}, 1828$, in the 27 th year of his age. Also of ALICE, eldest daughter of William and Elizabeth Jones, who died March 7th, 1844, aged 50."

"Sacred to the memory of JoHn Jones, late of Plas-fynnon, who departed this life December 10th, 1853, aged 61 years."

"In memory of Edward Bennion, Surgeon, Cyrn-y-Bwch, who died July 31st, 1844, aged 87. Also Alice Bennion, wife of the above Edward Bennion, who died July 16th, 1838, aged 70."

"In memory of EDWARD BEnNion (senior), Surgeon, who died February 27 th, 1788, aged 69. Also Elizabeth Batten and Elizabeth RoBERTs, who died in their infancy."

"MARgaret Cartwright, wife of Robert Cartwright, Surgeon, died June 28th, 1807, aged 29 years. RoBert CARTwright, died July 17 th, 1822 , aged 51 years."

"Sacred to the memory of GEORGE DoRSET OWEN, late of this Town, who departed this life November the 3rd, 1839, aged 52."

"Sacred to the memory of Edward Poweld, late of Preesgwyn, in this County, and of the Excise Office in the City of London, second son of Edward Powell, by Sarah his wife, who departed this life January 6th, 1825, and was interred the 12th of the same month, at St. Dunstan's Church, Mile End, Otd Town, Middlesex, aged 68 years. Underneath rest the mortal remains of JoHn PowesL, late of Preesgwyn, youngest son of the above Edward and Sarah Powell, who departed this life November 24th, 1825 , aged 63 years." 


\section{MONUMENTS IN THE NEW CHURCH-YARD.}

"In a vault beneath this stone are deposited the mortal remains of MARY, the beloved and affectionate wife of Mr. William Faulder, late of this town, and mother of Margaret, wife of John Richard Powell, of Preesgwyn, who died February 17 th, 1847, in the 73rd year of her age."

"Underneath lie the remains of MAREARET JENnings, eldest daughter of Thomas and Margaret Jennings, of Penylan. She died May 12th, 1826, aged 59. Also the remains of MARY, youngest daughter of Thomas and Margaret Jennings, who died 31st of March, 1834, aged 61. Also the remains of EDWARD, the youngest son of Thomas and Margaret Jennings, who died November 27th, 1835, aged 61. Also the remains of Thomas, eldest son of Thomas and Margaret Jennings, who died July 26th, 1844, aged 74. Underneath are deposited the remains of Thomas Jennings, of Penylan. He died 17 th of December, 1805, aged 79. Also the remains of Margaret Jennings, relict of Thomas Jennings, of Penylan, She died the 31 st of March, 1811, aged 79. JANE, the wife of John Wolfe, of Penylan, departed this life July 19th, 1695. SinaH, the second wife of John Wolfe, of Penylan, departed this life October 25th, 1736, aged 77. Mary Jennings, of Penylan, (widow), departed this life November 11 th, 1756 , aged 51. JонN Wolfe, of Penylan, departed this life July 3rd, 1739, aged $80 . "$.

"Edward Gough, departed this life March 14th, 1803."

"Also to the memory of Catherine Williams, who departed this life April 28th, 1840, aged 97."

"Also to the memory of MARIA, relict of the above-named Edward Gough, who departed this life February 25th, 1853, aged 82."

"Sacred to the memory of Thomas PotTER MACQueEn, late of Ridgemount, Bedfordshire, Lieutenant-Colonel of the Beds. Yeomanry Cavalry, and M.P. for that County, born May 28th, 1792, died March 31st, 1854."

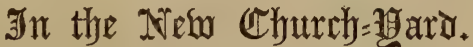

"In memory of CHaRlotte Elizabeth URwick, eldest daughter of Thomas and Frances Penson, and wife of William Urwick, of Ludlow. She died of consumption, at Torquay, on the 26 th of November, 1846, aged 30 years. In this dispensation of the Divine will, her parents have to sorrow for a most dear and dutiful daughter, and her husband to bemoan the loss of an affectionate wife. Her remains, with those of her only child, Thomas Penson URwick, who died on the 27 th of May, 1847, aged 13 months, are deposited beneath."

Near this place are deposited the remains of HANNaH Penson, who 


\section{TRINITY CHURCH.}

died an infant, on the 28th of September, 1823. And underneath lie the remains of SARAh Maria Penson, who died on the 25th of April, 1829, aged 8 years. Also the remains of Henry Penson, who died on the 1 st of May, 1832, aged 12 years; children of Thomas and Frances Penson.

'Happy children, early blest,

Rest, in peaceful slumbers rest.","

"Sacred to the memory of JANE, daughter of Edmund Faunce, Esq., late Lieutenant-Colonel of the 4th or King's own regiment, and Bridget his wife, who died April the 12th, 1826, aged 16. Also sacred to the memory of the above-named EDwARD FAUNCE, Esq., of St. Mary's Hall, county of Kent, late Lieutenant-Colonel in the 4 th or King's own regiment. He died September 29th, 1838, aged 72."

"Sacred to the memory of JoHN WILLIAM Bourke, obiit August 21st, 1823, ætat. suæ 47. Sacred to the memory of ANNE, relict of the Rev. John William Bourke, who died October 22nd, 1833, aged 73."

\section{TRINITY CHURCH.}

The great want of accommodation for the poor in the Parish Church led to the building of another church, in the outskirts of the town, in the year 1835. This church, dedicated to the Holy Trinity, was consecrated by the Bishop

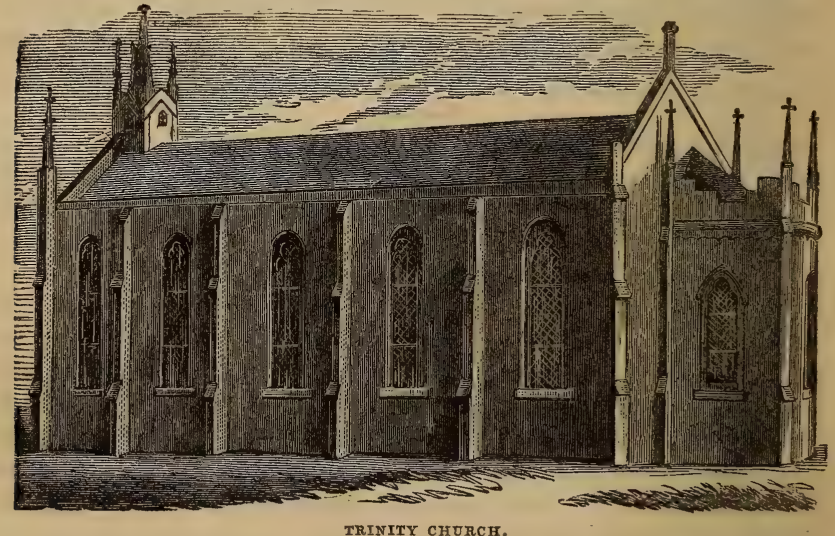

of St. Asaph (Dr. Carey) in 1837, and a district, consisting of the wards of Leg-Street and Beatrice Street, in the town, 148 


\section{TREFONEN CHURCH.}

and of the townships of Middleton, Hisland, Wootton, Aston, and Maesbury, has since been formed for it by the Church Commissioners. The population of the district so assigned was estimated at the time at about 2,300. The church contains accommodation for 700 persons, for about 400 of whom there are free sittings. The ornamental parts of the interior were executed at the expense of the Rev. John Parker, of Sweeney Hall, Vicar of Llanyblodwel. The Viscount Dungannon presented a handsome bible and prayer book, and the communion services, for the use of the church. The communion plate was given by the late Earl of Powis. T. L. Longueville, Esq., has also been a most liberal contributor to the church, both in presenting an organ, and in subscribing largely to the original structure, and to the subsequent improvements. A school-room at Maesbury, with a house for the master, was built some years since in this district, and subsequently licensed for the performance of worship by the Bishop of St. Asaph, and which is served gratuitously by the Incumbent of Trinity Church. It is much to be desired that a chapel-of-ease were erected in this part of the parish. Trinity Church is now altogether separated from the living of Oswestry, the Vicar of Oswestry for the time being appointing the Incumbent. The present Incumbent is the Rev. Frederick Cashel, M. A.

\section{TREFONEN CHURCH.}

To meet the wants of the Welsh population of the parish, a church was built in the township of Trefonen, and consecrated in the year 1821; and in 1842 a district was assigned to it, by an Order in Council bearing date August 27th, consisting of the three townships of Trefonen, Treflach, and Treferclawdd. In 1851 this district contained 319 houses, and 1233 inhabitants-viz., 589 males and 644 females.

Trefonen Church, which is capable of containing about 500 persons, was built on a piece of land given for that purpose 


\section{RHYDYCROESAU CHURCH.}

by the late Sir W. W. Wynn, father of the present Baronet. It was originally intended that the service of this church should be wholly in Welsh; but, owing to the increase and prevalence of the English language, that intention was not persevered in, and the service has for some years past been performed in Welsh and English alternately. A substantial school-room, with a house for the Master, was erected in the year 1825, upon a portion of the glebe given for that purpose, with the sanction of the Bishop, by the late Incumbent, the Rev. Edward Jones, and which has been of great advantage to the district. The living is a perpetual curacy, in the patronage of the Earl of Powis. The present Incumbent is the Rev. D. Lloyd.

Trefonen abounds in mineral wealth. Coal was raised in considerable abundance some years since in the adjoining township of Treferclawdd, but the pits there are now exhausted. It is still worked, however, in the township of Treflach, where there are also valuable and extensive quarries of lime. A mine was opened some years since in the Moelydd, which produces lead and calamine.

\section{RHYDYCROESAU CHURCH.}

In addition to the above means of providing church accommodation to the inhabitants of the parish, an additional advantage has been gained by annexing the two Welsh townships of Pentregaer and Cynynion to the new church at Rhydycroesau. This church is situated on the high road to Llansilin, about three and a half miles from the town of Oswestry. It owes its foundation to the Rev. G. N. K. Lloyd, late Rector of Selattyn, who contributed liberally himself, and, with the co-operation of the first and present Incumbent, the Rev. Robert Williams, M. A., raised a sufficient fund, by voluntary contributions, to complete the church and erect a glebe-house. The church was consecrated August 2nd, 1838, by the Bishop of St. Asaph, and the glebe-house was built 


\section{LIST OF VICARS.}

in 1840. It is a Consolidated District Church, licensed for all parochial purposes; and has a legally-assigned district, consisting of the townships of Cynynion and Pentregaer, in the parish of Oswestry; a detached portion of the parish of Llanyblodwel, called Cefnymaes; with portions of the parishes of Llansilin and Selattyn. A very neat Gothic building has also been erected by the present Incumbent, aided by voluntary contributions, and opened as a National School in January, 1850. The sites for the school and playground, as well as for the church and church-yard, are the munificent gifts of Sir Watkin Williams Wynn, Bart. The portion of the population of the parish of Oswestry thus transferred to the district of Rhydycroesau is about 200 .

Nothing is now needed to make the ecclesiastical arrangements of the parish of Oswestry complete but the building of a chapel-of-ease at Maesbury, and the annexing a district to Morton Chapel; the latter of which objects will no doubt be effected whenever a new Incumbent shall be appointed to it.

Oswestry is a discharged Vicarage, in the gift of the Earl of Powis. The present Incumbent is the Rev. Thomas Salwey, B. D.

\section{LIST OF VICARS.}

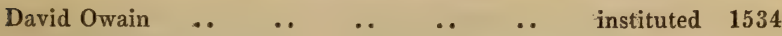
Rector of Whittington 1532, and Prebendary of Myfod 1534.

$\begin{array}{llllllll}\text { Peter Brereton .. } & \text {. } & \text {.. } & \text {. } & \text {. } & \text {.. } & \text {.. } & 1537\end{array}$

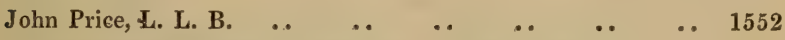

He became Prebendary of Myfod 1558, and Chancellor 1559.

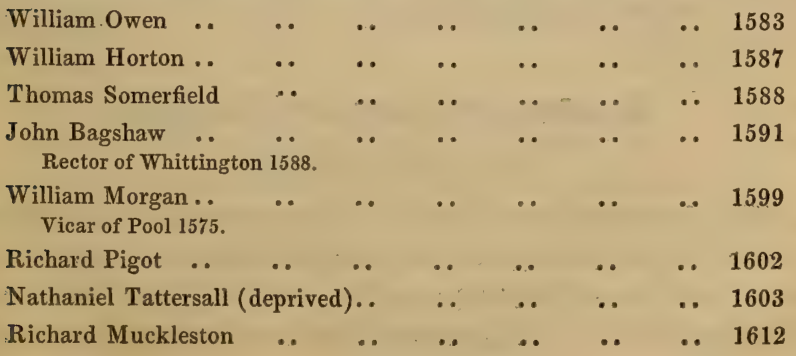




\section{THE OLD CHAPEL.}

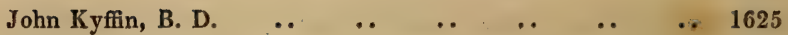

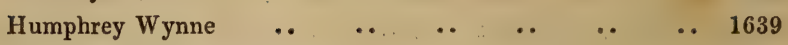

Rowland Nevet, A. M. ..

Ejected by the Act of Uniformity.

Richard Edwards,

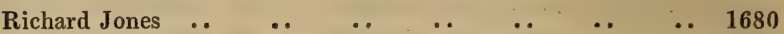

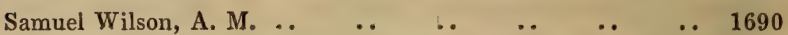

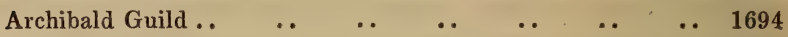

$\begin{array}{lllllllll}\text { Thomas Jones } & \ldots & \ldots & \ldots & \ldots & \ldots & \ldots & \ldots & 1697\end{array}$

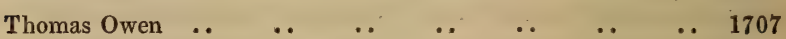

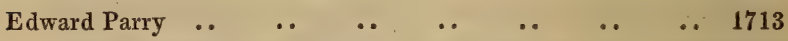

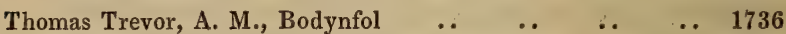

Turner Edwards, L. L. B., Talgarth $\ldots \quad \ldots \ldots, \ldots \quad \ldots 1784$ Vicar of Llansilin.

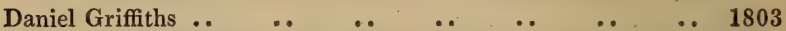

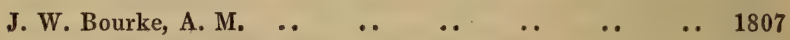

Vicar of St. Martins 1803.

Thomas Salwey, B. D. . . . $\quad$.. $\quad \ldots \quad$ December, 1823

The present esteemed Vicar of Oswestry, suffering much from illness, has long been unable to attend personally to the duties of his office. When however occasion has offered to promote, by his counsel and aid, any measure of benevolence in the Parish, he has been active in the good work. There are two Curates at present attached to the Parish Churchthe Rev. Llewelyn Wynne Jones, and the Rev. George Cuthbert, both of whom are zealous and faithful in their ministerial labours, and have acquired the regard and affection of the numerous congregations to whom they dispense the Bread of Life.

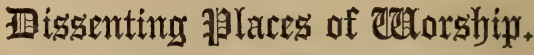 THE OLD CHAPEL.}

The Congregational. Church of Protestant Dissenters now assembling in the Old Chapel, Arthur-Street, was formed in the township of Sweeney, in the year 1662, and the Rev. Rowland Nevet, A. M,, ejected from the vicarage of Oswestry 


\section{THE OLD CHAPEL.}

by the Act of Uniformity, was its first pastor. Mr. Nevet laboured in the ministry for thirty years; seventeen as a clergyman of the established church, and thirteen as a dissenting preacher. Calamy, in his "Nonconformists' Memorial," mentions to his honour, that when the Plague prevailed at Oswestry, he still continued with his people, extending to them both temporal and spiritual aid. He died December 8 th, 1675 , and was succeeded by the Rev. James Owen, a distinguished minister, who bore part, as we have already mentioned, in a theological controversy which took place in the Oswestry Guildhall, in the year 1681, in the presence of Bishop Lloyd. He was appointed pastor at Sweeney in November, 1676 , the duties of which office he faithfully discharged, as well as those of chaplain to Mrs. Baker, a pious lady residing on her own estate at Sweeney Hall. Vestiges of the ancient burial-ground of the first Nonconformists are yet to be seen near the site of the old mansion at Sweeney, enclosed within iron railings by the late T. N. Parker, Esq. The following inscriptions are still legible:-

"Here lieth Mrs. Abigail Chetwood, daughter to Sir Richard Chetwood, who died the 1st May, 1658."

"Thomas Baker, Esq., deceased March 19, aged 68, A. D. 1675."

The above Thomas Baker served the office of High Sheriff of the county, in 1649, the first year of Cromwell's Protectorate; and in the parliament of 1653 he was summoned by Cromwell, with John Brown, of Little Ness, as a knight of the shire. In 1692 the place of worship was removed, for convenience, from Sweeney into the town of Oswestry. The room fitted up for religious worship was part of a house in Willow-Street, now known as the Butchers' Arms. Here $\mathrm{Mr}$. Owen laboured for eight years, and then removed to Shrewsbury, where he was soon placed at the head of the dissenting theological seminary. He was succeeded by the Rev. Jenkyn Evans, who died in 1709, and his funeral sermon was preached by the celebrated Mathew Henry. The Rev. Joseph 
Venables was the next minister appointed; and after $\mathrm{Mr}$. Venables came the Rev. Thomas Morgan. During his ministry the site on which the present chapel and chapelhouse stand was purchased, with an old maltkiln upon it, for $£ 38$. The sum of $£ 200$ having been given for the purpose by Mrs. Sarah Lloyd, a chapel was erected, and opened for public worship in July, 1750. The immediate successors of Mr. Morgan were Mr. Davies and Mr. Dewhurst; the latter became Socinian or Arian in his doctrines, and soon left. In September, 1777, the Rev. Dr. Edward Williams removed from Ross to Oswestry. In 1783 he enlarged the chapel ; and the Collegiate Institution at A bergavenny having been removed to Oswestry, Dr. Williams became its Tutor, and for the accommodation of the students he enlarged the chapel-house also. In 1791 he removed to Carr's-Lane, Birmingham; afterwards to Rotherham College, of which he was appointed Principal, and there he died. The Rev. John Whitridge, who had been minister of the Congregational Church at Newcastleunder-Lyme for nine years, succeeded Dr. Williams, and he remained the kind and benevolent pastor of his congregation, which greatly increased under his ministry, till the period of his death, October 11th, 1826. On the west side of the chapel, and orer the spot where the pulpit then stood, in which for thirty-five years he had dealt out the bread of life to his congregation, a plain marble tablet was erected, bearing the following inscription:-

"In Memory of the Rev. John Whitridge, this Tablet is affectionately inscribed by the Church over whom for 35 years he was the devoted Pastor. An example-in word-in conversation-in charity-in spirit-in faith-in purity. 'Whose praise is in the Gospel throughout all the Churches.' He was born 23rd March, 1760. Died 11th October, 1826. His body reposes in a tomb beneath, waiting the spirit's union at the resurrection of the just."

Dr. Jenkyn, of Wem, succeeded to the pastoral office, and afterwards the Rev. W. Reeve. The Rev. J. Davies was followed by the present able pastor, the Rev. James Matheson 


\section{THE BAPTIST CHAPEL.}

(son of the Rev. Dr. Matheson, the indefatigable Secretary of the Home Missionary Society), who entered upon his ministerial labours in September, 1851, and who, by his distinguished talents, great urbanity, and ardent zeal for the spiritual prosperity of his people, has succeeded in greatly increasing the number of his hearers, and in commending himself to the good opinion of all classes of his fellowtownsmen.

The present Chapel (of which we give a sketch) was built

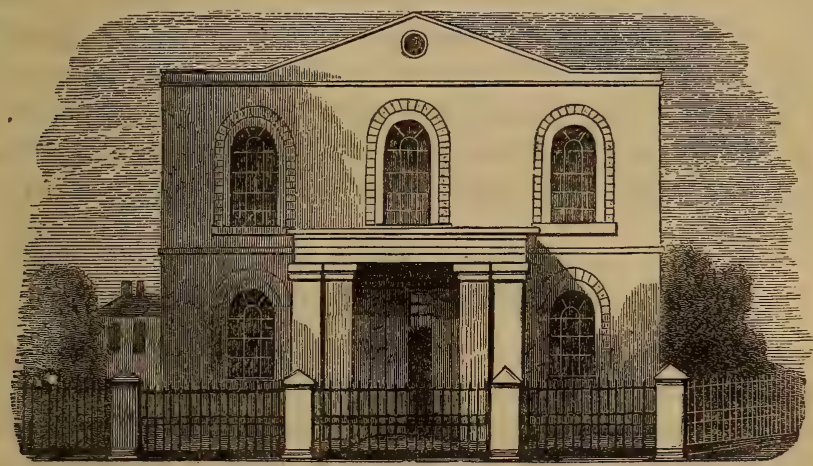

THE OLD CHAPEL.

during the ministry of the Rev. Dr. Jenkyn. The old Chapel having become too small for the increased number of hearers, it was pulled down, with the exception of part of one wall, and the present one was erected. It is a substantial and commodious place of worship, and capable of containing, when closely seated, about eight hundred persons.

\section{THE BAPTIST CHAPEL,}

Situated on the English Walls (opposite the Cattle Market), was erected by voluntary contributions, in the year 1805 , and enlarged in 1818. It contains two galleries, and will accommodate between 300 and 400 persons. The Baptist Church in Oswestry was formed September 6th, 1806, and then consisted of a few members dismissed from the Baptist 
Church, at Shrewsbury, at that time under the pastoral care of the late Rev. John Palmer, who, with other Baptist Ministers, preached the Gospel in Oswestry and its neighbourhood some time prior to the erection of the Chapel. The Rev. William Pain was the first Pastor, and was succeeded by the Rev. Thomas Cooke, in the year 1817, who, for twenty years, honourably sustained the office to which he had been chosen. In 1838 the Rev. Robert Clarke (late of Bridgnorth) became the Pastor; and his successor was the late Rev. H. G. Grainger, who settled in Oswestry, in the year 1846. The present Pastor, the Rev. David Crumpton, took the oversight of the Church in the year 1852. There is a Sabbath-School connected with this congregation. The Chapel is free from debt, as is also the Baptist Chapel at Sweeney, erected by this Church and congregation in the year 1831.

\section{THE WESLEYAN-METHODIST CHAPEL}

Is a plain brick building, situated in the Coney Green, and was erected in the year 1813. The interior is without galleries, but will accommodate on the ground floor about 500 persons. The Wesleyan body in Oswestry is included in the Wrexham Circuit, the present Superintendent being the Rev. Samuel Atkinson.

\section{ZION CHAPEL.}

Throughout the Principality the Calvinistic Methodists are the most numerous body of dissenters, and their annual meetings, or associations, are seasons of much interest and excitement. In 1814 a small chapel was erected on the Welsh Walls for the accommodation of persons of this persuasion resident in Oswestry, and this was occupied as a place of religious worship until 1836, when the great increase of the congregation rendered the erection of a larger chapel necessary. Accordingly the present building was commenced in Gatacre Place, and opened for public worship on the 6th of July, 1836. 156 


\section{PRIMITIVE METHODIST AND OTHER CHAPELS.}

It is a substantial stone structure, of rather imposing appearance, and affords accommodation for upwards of 500 persons.

\section{THE PRIMITIVE METHODIST CHAPEL.}

The first chapel erected by this body was on the site of the Bath in Upper Willow Street, and was opened in 1825. So rapid has been the increase of the members of this denomination, that from the summer of 1825 , when their first travelling preacher visited Oswestry, to the present time, they have built in this circuit no fewer than sixteen chapels; and the number of preachers on their quarterly plan amounts to 120 . Their place of worship in Willow Street having become incapable of accommodating their increasing numbers, the present chapel and chapel-house were erected in 1840, in Castle Street. It is a neat and convenient building, and will seat about 450 persons. . The Superintendent is the Rev. Thomas Parr.

\section{BETHESDA CHAPEL}

Is a small neat building in Castle Street, erected in the year 1844, for the use of the Welsh Congregationalists, or Independents. The Rev. Robert Thomas is the present Minister.

\section{THE INDEPENDENT ME'THODIST CHAPEL}

Stands below the Horse-Market, and was built in 1848 by a body of seceders from the Primitive Methodists. It is a plain brick building, and capable of seating about 300 persons.

Besides the above, there is a small but highly-respectable body of Christians who hold their meetings in the Assembly Room at Osburn's Hote], under the ministry of the Rev. J. Stewart; and also a congregation of Welsh Wesleyan-Methodists, who assemble in a school-room at Black Gate. 


\section{ftutritial and citril Goformment.}

The Corporation of Oswestry is of great antiquity. Its civic honours, primitively, flowed from its Barons or Lords, who, exercising themselves the power of petty sovereigns, appointed Bailiffs and other officers to superintend the civic affairs of the borough. Its first assumption of civic dignities appears to have been in the reign of Henry II., when William, Earl of Arundel, granted to the town a short charter (called by the Welsh "Siarter Cwtta"), denominated also a Charter of Protection. A clause in this ancient document sets forth that "I (the Earl of Arundel) have received in Protection my Burgesses of Blanc-Minster" (Oswestry). Richard de Chambre was Constable at this period. Here was subsidiary power given to the inhabitants of Oswestry, for the government of the town; but in the reign of Richard II., August 14th, 1399, that monarch granted to Oswestry its first royal charter, incorporating the Burgesses by the name and title of "The Bailiffs and Burgesses of Oswestry, infra I'alatinatum Cestria, in marchia inter Angliam et Walliam." In 1407, as heretofore noticed, Thomas, Earl of Arundel, granted a comprehensive and valuable charter, showing that still the exercise of power, in his lordship or barony, for the good government of the burgesses, \&c., was fully recognized by the crown.

The rights and privileges granted by Richard II. seem to have been strictly guarded and maintained by the inhabitants down to the reign of Elizabeth, when they were confirmed by that sovereign. It would appear, however, that subsequently "divers doubts and ambiguities" arose concerning the ancient liberties, franchises, \&c., of the borough, and in the reign of James I., 1616, the king granted a charter to the town, extending its liberties and privileges, and confirming the Bailiffs, Burgesses, \&c., as a body corporate, by the 


\section{SIR JOHN TREVOR.}

name of "The Bailiff and Burgesses of Oswestry, in the countie of Salop." The charter of Charles II., granted January 13th, 1673, to " the ancient borough and corporation of Oswestry, alias Oswaldstrey, in the county of Salop," enacted "That they be incorporated by the name of the Mayor, Aldermen, Common-Councilmen and Burgesses of Oswestry." This charter, it will be seen, was the instrument which first called into existence the offices of Mayor, Aldermen, Common-Councilmen, and Recorder. That charter was immediately acted upon, and Mr. Richard Pope was elected the first Mayor of Oswestry. Sir John Trevor, Knight (afterwards speaker of the House of Commons, and Master of the Rolls), Morgan Wynne, Esq., Edward Owen, Richard Edwards, Richard Lloyd, the before-mentioned Richard Pope, gentleman; Gabriel Edwards, woollendraper; Hugh Price, woollen-draper ; John Jones, mercer; Richard Jones, John Blodwell, gentlemen; and John Lloyd, mercer, were chosen as the first Aldermen. Richard Price, brewer, Richard Jones, mercer, John Glover, tanner, Richard Jones, glover, Edward Evans, apothecary, John Jones, glover, John Muckleston, shoemaker, Thomas Edwards, gentleman, Thomas Edwards, baker, Nathaniel Jones, brewer, Hugh Edwards, shoemaker, Timothy George, mercer, Thomas Vaughan, chandler, William Price, butcher, and Thomas Felton, brazier, were the first Common-Councilmen. Morgan Wynne, Esq., was the first Recorder of the town, and John Worral, Esq., first Common Clerk of the Borough, and Clerk of the Court. It may be mentioned as a fact worth knowing, that Sir John Trevor was the second Mayor of Oswestry, under the charter of Charles II. Sir John was an eminent man, and his history, connected as he was with the borough of Oswestry, is worthy of brief record in these pages. He was the second son of John Trevor, Esq., of Brynkinalt, in the county of Denbigh, by an aunt of Sir George Jeffreys. He was born about the year 1637, and it is supposed never received educational advantages beyond 159 


\section{SIR JOHN TREVOR.}

those furnished by a village school. He was sent to London to his uncle, Arthur Trevor, a leading barrister, who employed him as his clerk in his chambers in the Inner Temple. The Rev. Robert Williams, in his careful and elaborate "Biographical Dictionary of Eminent Welshmen," says of him, that "on his first arrival he displayed very lively parts, although his manners were rather uncouth, and he could not speak a sentence of correct English. His diligence, however, was so great, that being entered a student of the Inner Temple, he rendered himself well versed in all branches of his profession, and soon acquired extensive practice. Through the interest of his cousin, Sir George Jeffreys, he was made a king's counsel, in 1678 , and he obtained a seat in the House of Commons. Here he acquired considerable influence among the members, and such was his reputation as a high prerogative lawyer, that at the meeting of James II's. parliament in May, 1685, he was elected Speaker. In October of the same year he was appointed Master of the Rolls, and in July, 1688, he was sworn a Privy Councillor. On the accession of William and Mary, Sir John Trevor was dismissed from the office of Master of the Rolls. In the Convention Parliament he sat for Beraldstone, and opposed by every means in his power the measures of the Government. In the next Parliament, called in 1690, he made his peace with the Court, and was unanimously elected Speaker. In May, 1691, he was made first Lord Commissioner of the Great Seal, which office he held until May 2nd, 1693, and in January, 1693 he was restored to his office of Master of the Rolls. Such was his talent for managing party, and of recommending himself to the Government by his bold and dexterous measures, that had it not been for his great indiscretion, he would probably have reached the great object of his ambition, which was to become Lord Chancellor, and to be created a peer. In 1695 a violent outcry was raised against bribery, and a committee was appointed by the House of Commons, to inquire into the charges, which were 
made against members, and it reported that Sir John Trevor had received a bribe of a thousand guineas for furthering a bill called the "Orphan's Bill," promoted by the City of London. Accordingly, March 12th, 1695, he was subjected to the unparalleled humiliation of putting the resolution from the chair, and declaring himself guilty. He then resigned the chair, and was expelled from the House. Receiving money for voting in parliament was in those days so common, that his offence was not regarded in a very serious light, and he was permitted to retain his high judicial office of Master of the Rolls, for the long period of twenty-two years after his expulsion from the House of Commons. By the death of his elder brother he succeeded to the paternal estates of Brynkinalt, which, with large possessions of his own acquisition, have descended through his only daughter Anne to the present Viscount Dungannon. Sir John Trevor died May 20th, 1717, being nearly eighty years of age, at his house in Chancery Lane, and was buried in the Rolls Chapel." Yorke, in his "Royal Tribes of Wales," relates a droll anecdote of Sir John, which is worthy of transplantation. "Among his other virtues," says Yorke, "Trevor was an economist. He had dined by himself one day at the Rolls, and was drinking his wine quietly, when his cousin Roderic Lloyd was unexpectedly introduced to him from a side door. 'You rascal,' said Trevor to his servant, 'and you have brought my cousin Roderic Lloyd, Esquire, Prothonotary of North Wales, Marshal to Baron Price, and so forth, and so forth, up my back stairs. Take my cousin Roderic Lloyd, Esquire, Prothonotary of North Wales, Marshal to Baron Price, and so forth, and so forth; take him instantly back, down my back stairs, and bring him up my front stairs.' Roderic in vain remonstrated, and whilst he was conveyed down one, and up the other stairs, his Honor removed the bottle and glasses.'" Trevor had an obliquity of vision, or, in plainer words, he squinted abominably! When he was expelled from the House of Commons for bribery, pasquin161 


\section{CHARTER OF CHARLES II.}

ades were issued against him, in one of which it was wittily said, that "Justice was blind, but Bribery only squinted."

The charter of the 25 Charles II. (which was the governing charter previous to the passing of the Municipal Reform Act,) granted to the Borough of Oswestry a general Court of Quarter Sessions, to be held before the Mayor, the Steward, and the Recorder, or any two of them, of whom the Mayor was to be one. On the passing of that Act the Government refused to renew the grant of a separate Quarter Sessions, although strong and unanimous petitions from the town were presented in favour of this privilege. In 1842 , however, when the Ministry of Sir Robert Peel was in office, Sir James Graham being Secretary of State for the Home Department, the application was renewed, and was ultimately complied with. The grant is dated the 27th May, 1842, and under it John Robert Kenyon, Esq., was appointed Recorder. The first Quarter Sessions, under this grant, were held on July 8 th in the same year. Mr. Kenyon has ably and impartially discharged the duties of Recorder since that period; and to his legal acumen and zealous interest for the borough the inhabitants are indebted for many advantages.

The Corporation are chosen from the respectable and enterprising classes of the borough, so that all men who by perseverance and success in trade or commerce, in the learned profession of the law, or medical science, or who move in the quieter and more elevated ranks of life, where the otium cum dignitate is to be seen in perfection,-if to be seen anywhere,-are in the legitimate path to Magisterial authority and Aldermanic greatness.

The Municipal Act came into operation in Oswestry in January, 1836. James Edwards, Esq., was elected Mayor of the borough in 1834, and held office, pursuant to the new Act, until January 1st, 1836, on which day John Croxon, Esq., was elected the first Mayor under the Municipal Reform 162 
Act, and continued in office till November 9th, 1836, when Francis Campbell, Esq., was elected as the second Mayor of the borough under the same Act.

The Hon. Thomas Kenyon (second son of the celebrated Lord Kenyon, and father of the present Recorder of Oswestry) was appointed High Steward of the Borough in the year 1823. Mr. Richard Jones Croxon (who had succeeded Mr. Lewis Jones to the Town-Clerkship in 1834) was appointed Town-Clerk under the Municipal Act, and has continued to perform the duties of that office to the present time, with great credit to himself and satisfaction to the town.

Under the New Corporation Act the borough was divided into two Wards, viz., the East Ward, comprising 148 burgesses, and the West Ward, numbering 166 burgesses.

The Corporation of Oswestry, for the year 1854-5, consists of the following gentlemen :-

G. H. W I L L I A M S, M A Y O R.

Aldermen :

Thomas Longueville Longueville, $\begin{array}{ll}\text { Peploe Cartwright, } & \text { Thomas Rogers, } \\ \text { Thomas Hill, } & \text { Edward Morris, }\end{array}$

Thomas MrNshall.

Councillors :

\begin{tabular}{ll} 
William Hodges, & Thomas Edwards, \\
William Edwards, & James Thomas Jones, \\
Edward Wynne Thomas, & William Isac Bull, \\
David Lloyd, & William Morris, \\
George Morrall Bickerton, & Richard Kyrke Penson, \\
William Hayward, & John Lacon, \\
Francis Roberts, & John Minshall, \\
George James Saunders, John Phillips, \\
\multicolumn{2}{c}{ John Roberts. }
\end{tabular}

Town-Clerk:-R. J. CROXON.

Clerk of the Peace:-RoBERT SHMON.

Coroner:-JoHn MILES HaLES.

Treasurer:-GEORGE COOPER. 


\section{LIST OF MAYORS.}

We subjoin a full List of the Mayors of Oswestry, from the earliest period, with the names also of the entire body of other Corporate Officers, Aldermen, and CommonCouncilmen, elected under the Municipal Reform Act :-

1673 Richard Pope, first Mayor

1674 Sir John Trevor, Master of the Rolls

1675 Richard Edwards

1676 Richard Lloyd, Ford

1677 John Blodwell

1678 John Lloyd

Dying in his mayoralty, succeeded by Edward Owen

1679 Richard Price

1680 John Glover

1681 Peter Griffiths

1682 Humphrey Foulks

1683 William Price

Appointed instead of Thomas Edwards, who died before he was sworn

1684 Hugh Jones

1685 Phillip Ellis

1686 Sir Robert Owen, Porkington

1687 Roger Edwards

1688 Morgan Powell

1689 Thomas Jones

1690 Thomas Powell, Park

1691 Thomas Pritchard

1692 John Muckleston

1693 John Price

1694 David Lloyd

1695 Richard Jones

1696 Sir Robert Owen (second time)

1697 John Skye

1698 Nathaniel Edwards

1699 Peter Jones, Llanfyllin

1700 Francis Tomkies

1701 William Jones

170.2 Humphrey Davenport, Hayes-Gate
1703 Roger Green

1704 Thomas Powell, Park (second time)

1705 Robert Lloyd, Aston

1706 John Davies

1707 Edward Lloyd, Trenewydd

1708 Thomas Tornkies

1709 Thos. Kynaston, Maesbury

1710 John Price (second time)

1711 Richard Jones

1712 John Skye (second time)

1713 Roger Green (second time)

1714 John Davies (second time)

1715 Thomas Warter

1716 George Edwards

1717 Robert Lloyd, Aston (second time)

1718 Owen Hughes

1719 Thomas Edwards

1720 John Evans

1721 Richard Payne

1722 Richard Maurice

1723 Nathaniel Price

1724 Peter Povall

Dying in his mayoralty, succeeded by Owen Hughes

1725 John Kyffin

1726 Richard Thomas

1727 Edward Lloyd, Llwynymaen

1728 Watkin Williams Wynn

1729 Charles Lloyd, Trenewydd

1730 William Owen, Porkingtor

1731 John Huxley

1732 John Mytton, Halston

1733 Nathaniel Kynaston

1734 Richard Powell

1735 Robert Williams 164 


\section{LIST OF MAYORS.}

1736 Robert Barkley

1737 Thomas Jones

1738 John Burgess

1739 Corbett Kynaston

Dying in his mayoralty, succeeded by Thomas Tomkies

1740 William Price

1741 John Jones

1742 John Hughes

1743 John Mort

1744 Peter Williams

1745 David Morris

1746 Richard Lloyd

1747 Richd. Williams, Penbedw

1748 Vincent Phipps

1749 Nathaniel Jones

1750 John Griffiths

1751 John Williams

1752 John Griffiths

1753 Edward Price

1754 Thomas Jones

1755 John Jones

1756 Thomas Rathbone

1757 Edward Evans

1758 John Basnett

1759 Nathaniel Price

1760 Edward Evans

1761 Robert Lloyd

1762 Richard Price

1763 John Edwards

1764 Richard Jones

1765 John Gregory

1766 William Griffiths

1767 Richard Morrice

1768 John Evans

1769 John Lloyd

1770 Watkin Williams, Penbedw

1771 John Mytton, Halston

1772 Robert Godolphin Ówen, Porkington

1773 E. Thornes

1774 Sir Watkin Williams Wynn, Bart., Wynnstay
1775 William Griffiths

1776 Francis Chambre

1777 Joseph Richardson

1778 John Croxon

1779 Noel Hill, Shrewsbury

1780 Edward Brown

Dying in his mayoralty, succeeded by Nathaniel Price

1781 Thomas Vernon

1782 Edward Wynn Evans

1783 John Kynaston, Hardwick

1784 Richard Bickerton

1785 Thomas Howell

1786 Richard Salisbury

1787 Wm. Mostyn Owen, Woodhouse

1788- Lewis Jones

1789 John Gibbons

1790 John Lovett

1791 John Probert

1792 John Mytton, Halston

1793 Rev. Turner Edwards

1794 Arthur Davies

1795 Rev. John Robert Lloyd

1796 Owen Ormsby

1797 Thomas Lovett

1798 Robert Lloyd

1799 John Jones

1800 Sir W. W. Wynn, Bart.

1801 Richard Croxon

1802 Lawton Parry

1803 Richard Jebb

1804 Thomas Skye

1805 Rev. James Donne

1806 Robert Cartwright

1807 Thomas Longueville Jones

1808 William Lloyd

1809 Robert Roberts

1810 John Sheppard

Dying in his mayoralty, succeeded by Thomas Hilditch

1811 Edward Edmunds

1812 John Croxon 


\section{ALDERMEN AND COMMON-COUNCILMEN.}

1813 Rev. Charles Arthur Albany Lloyd

1814 Hon. Thomas Kenyon

1815 Thomas Morris

1816 S. Leach (R. Salisbury, Deputy)

1817 Rev. George Lloyd, Selattyn (Mr. Cartwright, Deputy)

1818 Thomas Netherton Parker

1819 H. W. W. Wynn (Mr. Salisbury, Deputy)

1820 W. Lovett (J. V. Jones, Deputy)

1821 John Bonnor, Brynygwalia (Robert Roberts, Deputy) 1822 Henry Pinson Tozer Aubrey

1823 W. Ormsby Gore

1824 John Mytton (Thomas Hilditch, Deputy)

1825 John Jones (second time)

1826 Rev. Turner Edwards

1827 Roger Mercy Cockerill

1828 Robert Morrall

1829 Peploe Cartwright

J830 Thomas Lovett
1831 Sir W. W. Wynn, Bart. (second time) (Dr. Donne, Deputy)

1832 Thomas Longueville Longueville

1833 John Jones, jun.

1834 James Edwards

1835 John Croxon

1836 Francis Campbell

1837 Charles Thomas Jones

1838 G. Dorset Owen

1839 Griffith Evans

1840 Thomas Penson

1841 John Hayward

1842 W. Williams

1843 W. Williams (re-elected)

1844 W. Price

1845 Thomas Rogers

1846 John Miles Hales

1847 Thomas Hill

1848 John Jones

1849 Edward Morris

1850 Edward Morris (re-elected)

1851 Thomas Minshall

1852 William Hodges

1853 Thomas Edwards

1854 George Harvey Williams

\section{ALDERMEN AND COMMON-COUNCILMEN.}

\section{ALDERMEN-1835 :}

John Jones

Richard Croxon

Thomas Morris
Peploe Cartwright

T. L. Longueville

John Jones, jun.

\section{COUNCILLORS-1835 :}

EAST WARD.

John Croxon

Francis Campbell

George D. Owen
WEST WARD.

John Hayward

Thomas Rogers

Edward D. Bennion 


\section{ALDERMEN AND COMMON-COUNCILMEN.}

COUNCILLORS, $1835-$ (CONTINUED):

EAST WARD.

Francis Lucas

Griffith Evans

James Howell

Richard Bill

William Price

William Roberts
WEST WARD.

Charles Thomas Jones

John Jones, jun.

Charles Sabine

William Williams

James Williams

Thomas Penson

\section{COUNCILLORS-1836 :}

Thomas Penson

John Miles Hales

Robert Edwards

John Croxon

Francis Campbell

George Dorset Owen

Francis Lucas

Griffith Evans

James Howell

Edward Edwards (in the room of James Williams, deceased)

William Williams

John Tomkies

John Hayward

Thomas Rogers

Edward David Bennion

Charles Thomas Jones

John Jones, jun.

Charles Sabine

1837 :

Francis Lucas

Griffith Evans

James Howell

Thomas Penson

John Miles Hales

Robert Edwards

John Croxon

Francis Campbell

George Dorset Owen

Charles Thomas Jones

Thomas Jones Rogers

John Davies

Edward Edwards

William Williams

John Tomkies

John Hayward

Thomas Rogers

Edward David Bennion

ALDERMEN-RE-ELECTED IN 1838 :

Peploe Cartwright, T. L. Longueville, and John Jones, jun.

COUNCILLORS-1838 :

George Dorset Owen

David Thomas

William Smale

Francis Lucas

Griffith Evans

James Howell

Thomas Penson

John Miles Hales

Robert Edwards

167
John Hayward

Thomas Rogers

Nathaniel Minshall

Charles Thomas Jones

Thomas Jones Rogers

John Davies

Edward Edwards

William Williams

John Tomkies 


\section{ALDERMEN AND COMMON-COUNCILMEN.}

\section{COUNCILLORS-1839:}

EAST WARD.

Thomas Penson

John Miles Hales

Robert Edwards

William Price (in the room of G. D. Owen, deceased)

David Thomas

William Smale

Francis Lucas

Griffith Evans

Richard Salter (in room of

James Howell, deceased)
WEST WARD.

William Williams

John Tomkies

Edward Edwards

John Hayward

Thomas Rogers

Nathaniel Minshall

Charles Thomas Jones

Thomas Jones Rogers

Richard Cross (in the room of

John Davies, deceased)

1840 :

Francis Lucas

Griffith Evans

Richard Salter

Thomas Penson

John Miles Hales

Robert Edwards

William Price

David Thomas

William Smale
Richard Powell (in the room of Thomas Jones Rogers)

Richard Cross

Thomas Hughes (in the room of Charles Thomas Jones, appointed Alderman)

John Tomkies

William Williams

Edward Edwards

John Hayward

Thomas Rogers

Nathaniel Minshall

ALDERMEN-1841 :

Thomas Penson (in the room of John Croxon, who had left the borough)

Charles Thomas Jones

John Jones

\section{COUNCILLORS-1841 :}

John Miles Hales

William Price

David Thomas

William Smale

Francis Lucas

Griffith Evans

Richard Salter

Robert Edwards

Charles Osburn (in the room of Thomas Penson)
John Hayward

Thomas Rogers

Nathaniel Minshall

Richard Cross

Thomas Hughes

Richard Powell

William Williams

John Tomkies

Edward Edwards 


\section{ALDERMEN AND COMMON-COUNCILMEN.}

\section{COUNCILLORS-I842 :}

EAST WARD.

John Miles Hales

Robert Edwards

William Price

David Thomas

Griffith Evans

William Smale

Richard Salter

Charles Osburn

Pryce Morris (in the room of Francis Lucas)
WEST WARD.

William Williams

John Tomkies

Edward Edwards

John Hayward

Thomas Rogers

Nathaniel Minshall

Richard Cross

Thomas Hughes

Richard Powell

Henry Hughes appointed Coroner June 20th, 1842.

1843 :

\begin{tabular}{l|l} 
Griffith Evans & \multicolumn{1}{|c}{ Richard Cross } \\
Richard Salter & Thomas Hughes \\
Charles Osburn & Edward Williams \\
John Miles Hales & William Williams \\
Thomas Hill (in the room & John Tomkies \\
$\quad$ of R. Edwards, deceased) & Edward Edwards \\
Pryce Morris & John Hayward \\
William Price & Thomas Rogers \\
David Thomas & Nathaniel Minshall \\
William Smale &
\end{tabular}

ALDERMEN-RE-ELECTED NoveMBER, 1844 :

T. L. Longueville, Peploe Cartwright, and John Jones, jun.

\section{COUNCILLORS-1844:}

John Broughall (in the room of David Thomas)

William Smale

Griffith Evans

Richard Salter

Charles Osburn

John Miles Hales

Thomas Hill

Thomas Minshall (in the room of Pryce Morris)
Thomas Rogers

John Hayward

Nathaniel Minshall

Thomas Savin (in the room of Richard Cross)

John Jones (in the room of

Thomas Hughes)

Edward Williams

William Williams

John Tomkies

Edward Edwards

1845 :

Thomas Hill

John Miles Hales

William Williams

William Price 169

John Phillips

Edward Edwards

Charles Humphreys

Thomas Rogers 


\section{ALDERMEN AND COMMON-COUNCILMEN.}

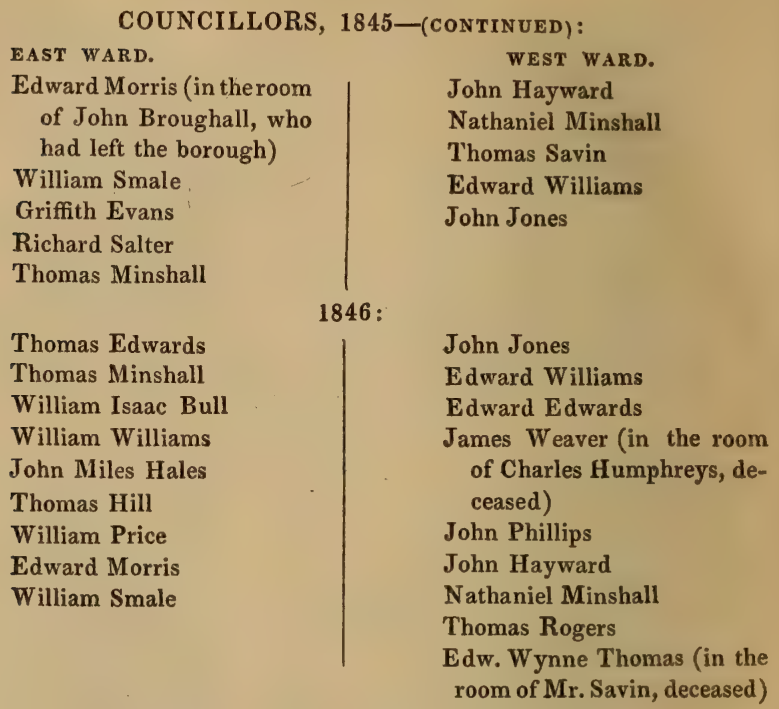

ALDERMEN-ELECTED November, 1847 :

John Hayward, Thomas Penson, and William Williams. COUNCILLORS-1847 :

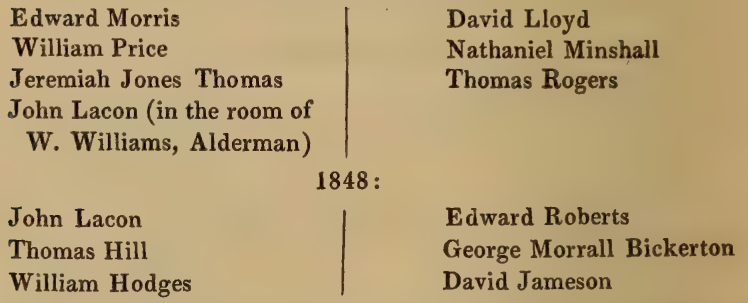

John Miles Hales appointed Coroner, and Robert Simon Clerk of the Peace, April 27th, 1848 (in the room of Henry Hughes, deceased).

\section{9 :}

Thomas Minshall

William Isaac Bull

Walter Edwards
John Jones

Edward Williams

Edw. Wynne Thomas

ALDERMEN-ELected November, 1850 :

T. L. Longueville, Peploe Cartwright, and Thomas Rogers. 


\section{ALDERMEN AND COMMON-COUNCILMEN.}

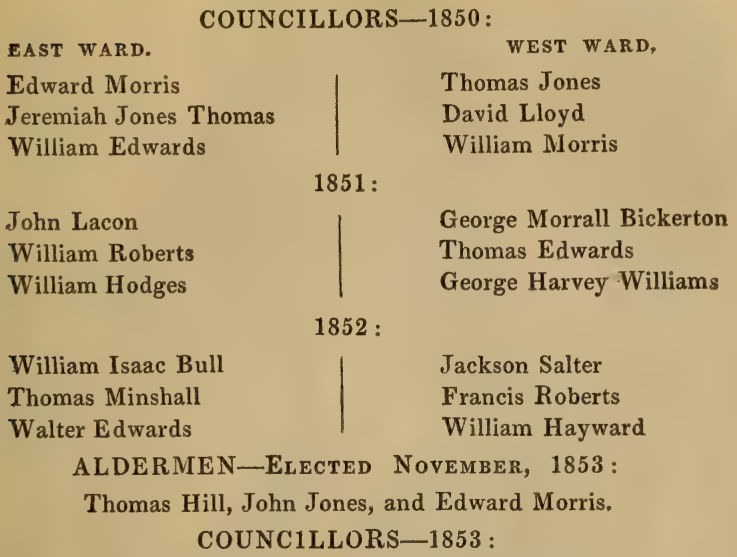

Edw. Wynne Thomas

William Edwards

William Morris

James Thomas Jones

David Lloyd

William Morris

1854:

John Lacon

William Roberts

Thomas Edwards

William Hodges

Benjamin Churchill (in the room of Walter Edwards, resigned)

George Morrall Bickerton

George Harvey Williams

[For the above List of Aldermen and Common-Councilmen, up to and including 1846, we are indebted to the Representative of a gentleman who filled the Civic Chair, and who for many years recorded the changes in the Municipal Body. The subsequent List is from the Corporation Poll Books.] 


\section{Intitimutititer.}

OSWESTRY CASTLE.

(9)

UR readers will have already learnt that Oswestry, from an early period in the history of the nation, bore no undistinguished part. Fixed in the midst of an arena of fierce and convulsive conflicts for many ages; its early state of warlike defence, rendered so complete by the sagàcious Edward I., and forming a powerful post on the Border Lands, the eyes of monarchs and their gallant nobles were frequently directed towards it for succour or defence. The Castle, in its primitive state, may have been a palace fit for regal splendour. The honour of erecting it is assigned, as we have previously mentioned, to Madog, descended from an illustrious Welsh Prince, the strenuous ally of Henry II., in his Welsh wars, and whose sire was the constant confederate of Randel the Third, and of his son, Hugh Cyveiliog, the fourth Earl of Chester. Madog was a man of high distinction in his day, and, being Prince of Powys, of which division Oswestry formed a part, there is presumptive evidence that the Castle was built by him, as the Welsh historians maintain, or very considerably enlarged or repaired. The English records fix its existence even before the Norman Conquest, and show that "Alan, a noble Norman," received it immediately from William the Conqueror, on his accession. "This Alan," adds Dugdale, the historian, "was the stock of the Fitz-Alans, Earls of Arundel; a potent race that flourished (with fewer checks than are usual with greatness) for near five hundred years." It may be necessary to mention here, to aid the reader as to dates, that Madog died A. D. 1159, and that the Norman Invasion occurred in 1066. If Dugdale is to be relied upon, the Castle of Oswestry was built at a period anterior to the Conquest, but he makes no mention of Madog. He says, "There was a Castle at Oswaldster at the time of the Conquest;" and Pennant, a good authority, adds to this note of Dugdale, "I think it very probable." The able Welsh tourist further remarks, "The artificial mount on which it was placed indicates it to have been earlier than 172 


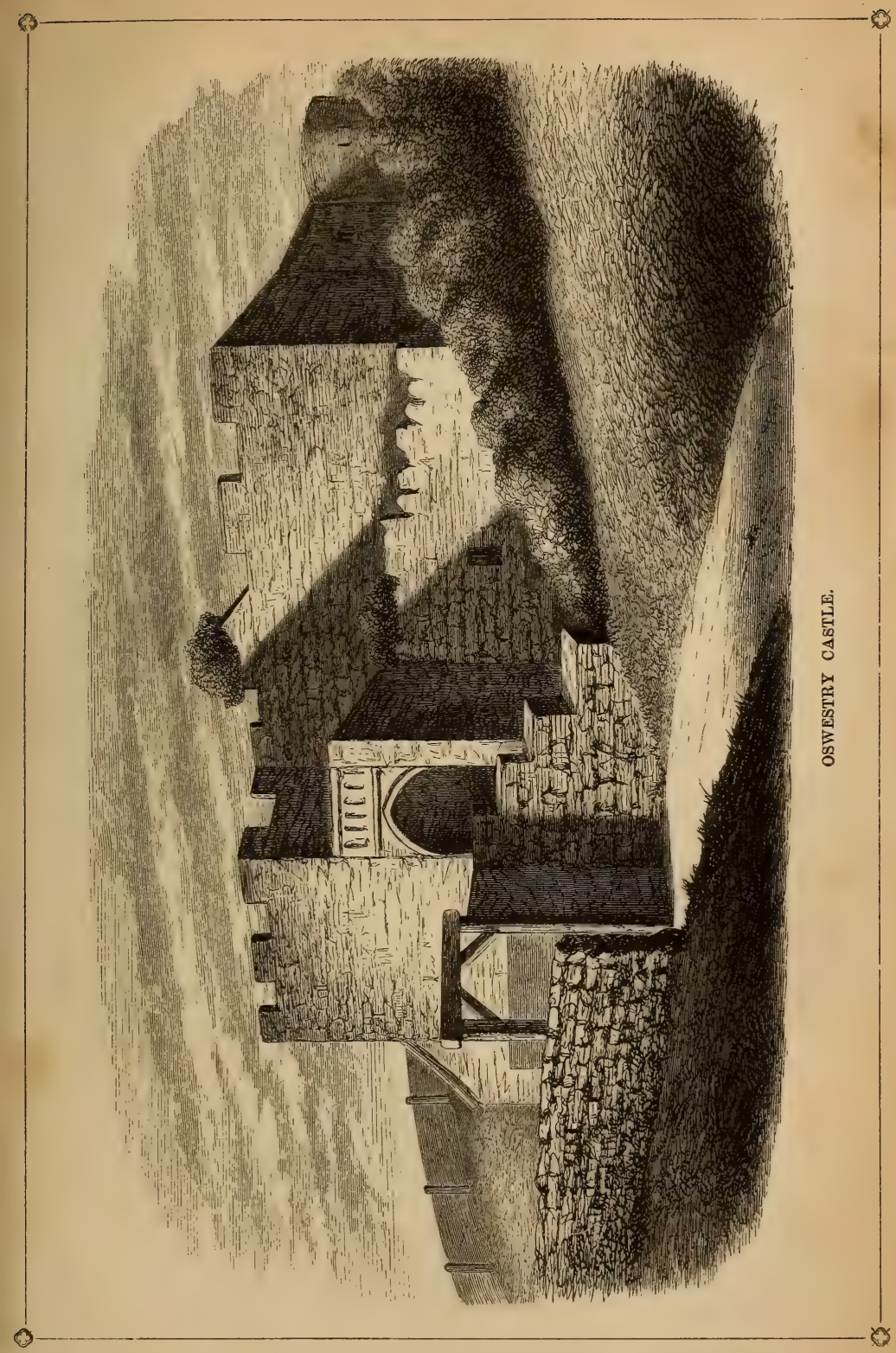



the Norman era. The Britons and the Saxons gave their fortresses this species of elevation. The Normans built on the firm and natural soil or rock, but often made use of these mounts, which they found to have been the site of a Saxon castle. I believe this to have been the case with that in question. A Fitz-Alan repaired or re-built, and added to that which he met with here : a tower also (as is not unfrequent) might receive the name of $M a d o g$, complimentary either to the son of Meredydd (Madog's father), or some other great man of the same title." We have collected all the authorities we could find on this vexed question; but the actual date of the building of the Castle, and the veritable party to whom the honour of founding it is due, are still among the undiscovered facts of ages past.

There is still, however, a notable event connected with Oswestry Castle that gives to its history surpassing interest, and ranks it among the more remarkable military relics of the nation. If the pains-taking researches of Chalmers, the historian of Scotland, are to be relied upon, one of the distinguished occupants of Oswestry Castle was the founder of the Stewart royal family. The real origin of that race of sovereigns had long perplexed genealogists; but the labours of Chalmers, who has minutely investigated all the written and printed records on the subject, have proved beyond further controversy that Walter, the son of Alan (the two first Norman possessors of Oswestry Castle), the son of Flaald, and the younger brother of William, the son of Alan, who was the progenitor of the famous house of Fitz-Alan, the Earl of Arundel, was the first of the Stewarts. Symon, and other Scotch historians, trace the Stewart family to a Thane of Lochabar. Lord Hailes disputed this and other opinions, treating them as fabulous, but it was reserved for Chalmers to establish and set at rest the long-contested question as to the origin of the Stewart race. Lord Hailes himself acknowledges that Walter, who flourished under David the First of Scotland, and Malcolm the Fourth, was indeed the first Stewart of Scotland; but he is unable to determine 1.73 


\section{OSWESTRY CASTLE.}

where, and what was the commencement of this family. The subject is important to every native of our land; but to the people of Oswestry it is of paramount interest, as it connects with the town, however remotely, the genealogy of our present beloved monarch, Queen Victoria.

Chalmers' evidence on this subject is curious and interesting. Hetells us that the great exploit of Walter, the son of Alan, was the founding of Paisley monastery, during the reign of Malcolm $I V$., by transplanting a colony of Cluniac monks from the monastery of Wenlock, in Shropshire. Such, then, he adds, was the connection of Walter the First Stewart with Wenlock, and with Isabel de Say, who married William, the brother of Walter. Alan, the son of Flaald, married the daughter of Gwarine, the famous Sheriff of Shropshire, soon after the Norman conquest; and of this marriage William was the eldest son of Alan, and the undoubted heir both of Alan and of Gwarine. Alan, the son of Flaald, a Norman, acquired the manor of Oswestry soon after the Conquest. Alan was undoubtedly a person of great consequence at the accession of Henry I. He was a frequent witness to the king's charters, with other eminent personages of that court. Mr. Chalmers, in his further investigations, proves the fraternal connection of William, the son of Alan, by a transaction which had before been as new to history as it is singular in itself. It has already been shown that Oswestry was the original seat of Alan on the Welsh border. Clun was added to his family by the marriage of his son William, who built Clun Castle; and John Fitz-Alan, Lord of Clun and Oswestry, by marrying Isabel, the second sister of William de Albany, the third Earl of Arundel, who died in 1196, became Earl of Arundel, and changed his residence from Shropshire to Sussex. Now, Richard Fitz-Alan, Earl of Arundel, being with Edward III., during the year 1335, and claiming to be Stewart of Scotland by hereditary right, sold his title and claim to the king for 1000 marks, which purchase he cautiously had confirmed to him by 174 
Edward Baliol; but Richard Fitz-Alan had not any right to the Stewartship of Scotland. Walter, who was the first purchaser of this hereditary office, was the younger brother of William, the son of Alan, the progenitor of Richard FitzAlan, the claimant; and till all the descendants of the first purchaser had failed, the claim could not ascend to the common father of the two families. But Robert the Stewart, who was born of Margery Bruce, on the 28th March, 1315-16, and became King of Scots the 2nd February, 1370-1, under the entail of the crown, was then in possession of the hereditary office of Stewart, by lineal descent. Walter, the son of Alan, undoubtedly obtained from David I., and from Malcolm IV., great possessions, a high office, and extensive patronage, and it may be reasonably asked, by what infiuence he could acquire from two kings so much opulence, and such an office? David I. was a strenuous supporter of the claims of his niece, the Empress Maud, in her severe contest with Stephen. William, the brother of Walter, influenced. by the Earl of Gloucester, the bastard son of Henry I., and other powerful partizans of his sister the Empress, seized Shrewsbury in September, 1139, and held it for her interest. He attended her, with King David, at the siege of Winchester, in 1441, where they were overpowered by the Londoners, and obliged to flee. Such then were the bonds of connection between David I. and the sons of Alan, who were also patronized by the Earl of Gloucester. It was probably on that occasion that Walter accompanied David into Scotland. William, the son of Alan, adhered steadily to the Empress, and was rewarded by Henry II. for his attachment. Thus Walter, the son of Alan, could not have had more powerful protectors, than the Earl of Gloucester with David I., and Henry II. with Malcolm the II. When Walter, by those influences, obtained grants of Renfrew with other lands, and founded the Monastery of Paisley for Cluniac Monks from Wenlock, he was followed by several persons from Shropshire, whom he enriched, and by whom he was supported. $\mathrm{He}$ 175 
married Eschina, of Moll, in Roxburghshire, by whom he had a son Alan, who succeeded him in his estates and office when he died, in 1177. Six descents carried this family, by lineal transmissions, to Robert the Stewart, whose office, as already stated, was purchased by Edward III., and who became King of Scots 1371: Walter, the son of Alan, was followed by his brother Simon. Thus does Mr. Chalmers treat the history of the Stewarts, whose blood, he says, runs in a thousand channels.

This historical subject has attracted the attention of a talented resident of Oswestry, whose taste and research, united with genius and poetic imagination, have already conferred upon the town no trivial honour. That gentleman has favoured us with a notice of the Castre Hill, which bespeaks the enthusiasm of the writer, and adds to the interest which all lovers of history must feel on a topic so closely connected with the present amiable Sovereign of the kingdom. It is only due to Mr. SABine to state (for to him we are indebted for aid in endeavouring to elucidate a dark and hitherto uncertain portion of Border History) that he has shed light even upon the pains-taking researches of Chalmers, and done much towards establishing a fact which, as we now consider it to be "proven," cannot fail to confer upon Oswestry an historical importance of no common degree.

Mr. SABINE's paper we have pleasure in quoting entire:"There is nothing," he remarks, "in the appearance of this Hill very imposing or very remarkable. It is a somewhat abrupt mound, with some rude fragmentary remains of the castle, with which it was formerly surmounted. It has long been a moot question whether this mound is natural, or whether it has been raised by artificial means. Its appearance would seem to indicate that it is the work of man; but an examination of its geological composition, and a comparison of it with similar surrounding elevations, lead to the conclusion that it is the accumulated deposit of ages during a period in which the district has probably been the 


\section{OSWLSTRY CASTLĖ.}

area of obstructed and pent-up waters, which, having becn set at liberty, have left exposed the present undulated portions of the district, of which this mound forms one of the most prominent. Its present abrupt character-abrupt as compared with some of the more shelving banks-is easily and obviously accounted for by manifold encroachments, and by the military necessity for making the Castle as inaccessible as possible to hostile attacks. But if there is nothing in the appearance of the Castle Hill of Oswestry that is remarkable, this cannot be said of its history ; for if there can be one fact topographically of greater interest than another in the history of a kingdom, it is that which is connected with the origin of its reigning monarch. To say nothing, then, of the numerous battle scenes of which Oswestry Castle has been the witness, and of which, it might say with ÆEneas, 'Quorum pars magna fui, a note of Sir Walter Scott's to the "Monastery" will be a sufficient warrant for saying that Oswestry, in point of historic interest, is second to no town in the united kingdom. 'The acute pen of Lord Hailes (says the author of Waverley), which, like the spear of Ithuriel, conjured up so many shadows from Scottish history, had dismissed among the rest those of Banquo and Fleance, the rejection of which fables left the illustrious family of Stewart without an ancestor, beyond WALter, the Son of AlÁN. The researches of our late learned Antiquary detected in this Walter the descendant of Alan, the son of Flaald, who obtained from William the Conqueror THE CAstle of Oswestry, in Shropshire; and who was the father of an illustrious line of English nobles, by his first son, William, and by his second son, Walter, the progenitor of the royal family of Stewart.' Few will be bold enough, even if so disposed, to question the authority of such an antiquarian as Sir Walter Scott, especially in matters relating to his own country. Assuming, then, that Alan Fitz-Flaald is the stirp of the Stewart House, a genealogical table may not be uninteresting to the readers of this work: 
GENEALOGICAL TABLE.

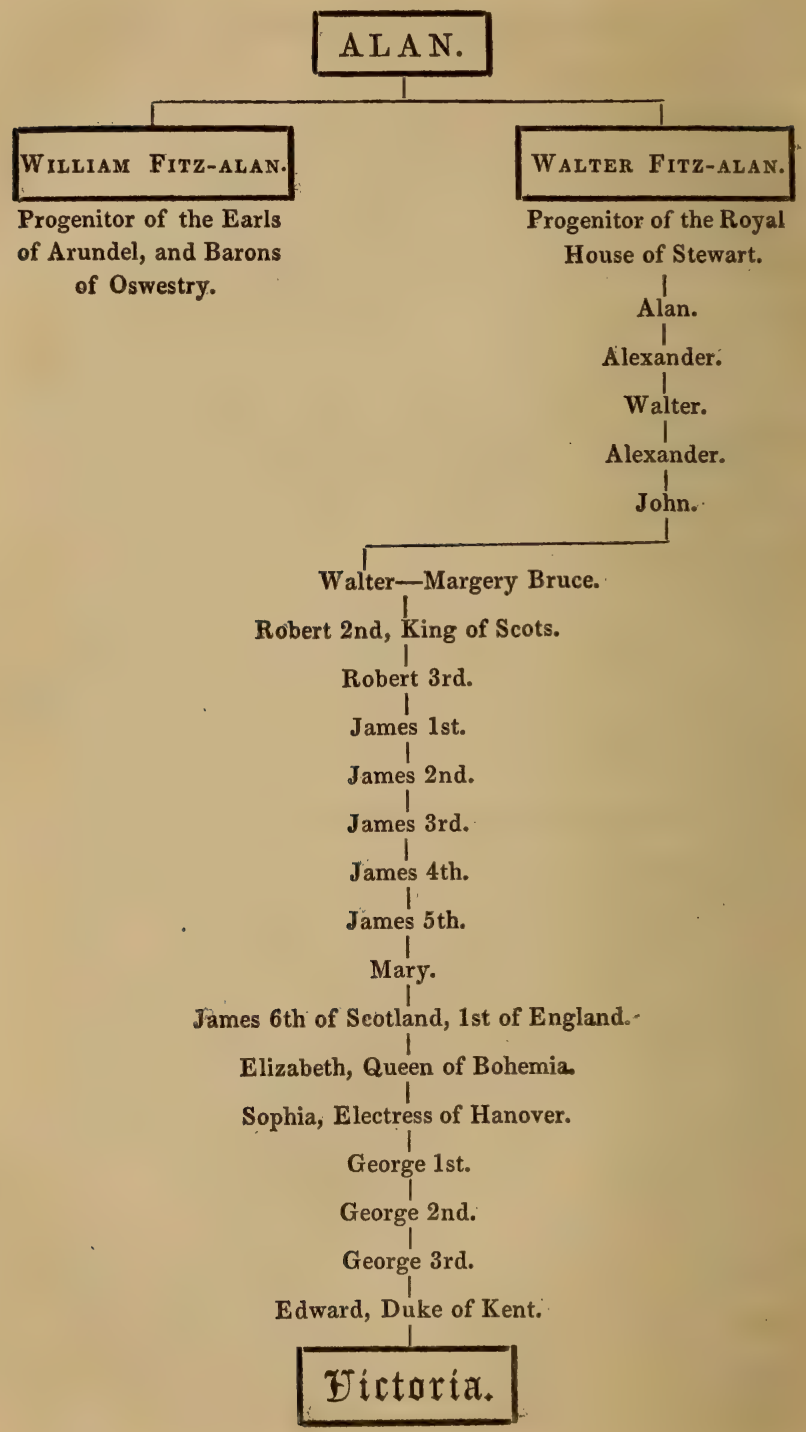




\section{OSWESTRY CASTLE:}

"That Sir Walter Scott is as indubitable an authority ir early English or Welsh History as in that of his own country may not be admitted by all. According to the Welsh records Oswestry belonged to Madog, Prince of Powys, who resided at Oswestry, and built the Castle there about the year 1140 . His second wife, Maud Vernon, an English lady of noble birth, on the death of Madog, married William Fitz-Alan, Lord of Clun, who in right of his wife obtained the Town and Castle of Oswestry. This William was a descendant of Alan who (says the Welsh Historian) came over with William the Conqueror, and was the first of the Fitz-Alans that was Baron of Oswestry. Again, the English historians assign to Oswestry Castle a more ancient date than 1140. They inform us that it was in being before the Norman conquest; and that Alan, a noble Norman, had the Town and Castle bestowed upon him by the Conqueror, soon after his accession. But whether Walter the Steward was the grandson of Flaald, and of Welsh descent, or whether his father came over from Normandy with the Conqueror, it may be taken as a fact that Walter, the son of Alan, the younger brother of William FitzAlan, went from Oswestry Castle, of which his father was Governor, into the service of David I., King of Scotland, as that monarch's Steward, and was the founder of the house of Stewart. The following extract from Chambers' Journal is concurrent in testimony with the main features of the above, and is fraught with additional interest, as it shows how greatly Scotland was indebted to the old Town of Oswestry for its progress in civilization :-

'During the troublous conflicts of Maud and Stephen, in their competition for the crown of England, Walter, the son of Alan, the son of Flaald, fled from the family seat at Oswestry, and settled in Scotland. David I. made him his Steward, and gave him lands to support the dignity of his office. By the charter we learn that these lands were those of "Passaleth (Paisley), Polloc, Talahee, Ketkert, le Drop, le Mutrene' 179 


\section{OSWESTRY CASTLE.}

Egglesham, Louchwinnock, and Inverwick." These estates in Renfrewshire (then a portion of Lanarkshire) were confirmed by Malcolm IV. in 1157, when he made the office of Steward hereditary, and granted, in addition, various other estates in the same quarter. Besides these possessions, Walter acquired the western half of Kyle, in Ayrshire, which hence was called Kyle Stewart. At this period the country was in a semibarbarous state; but Walter the Stewart introduced new and civilized usages. He settled many of his military followers on his lands, and, founding the Abbey of Paisley, introduced a body of instructed men, who taught the ancient people domestic arts and foreign manners. By the marriage of one of these Stewarts with Margery Bruce, Robert the Stewart was born, and became, 1370-1, King of Scots.'

"The Hill which claims this unique and unquestionable honour, in defiance of all the various contradictory and exploded fables which would give it to Scotland (for no spot in England seeks to withhold it from Oswestry), has been rescued from the destruction with which it has long been threatened, both by the encroachments of time and thoughtless spoliation, having been purchased by several of the Inhabitants of Oswestry, and vested in James Thomas Jones, Esq, as their Trustee, and is now planted as an Arboretum. The panoramic view from this Hill is one of the most beautiful scenic gems in the neighbourhood; and when the shrubs which have been planted shall have overcome the obstacles to their luxuriant growth, arising from exposure to bleak winds, and a comparatively uncongenial soil, it will constitute an ornament to the Town of Oswestry, such as few localities can boast; and which, in addition to its historic interest, will render it a spot, of which the Inhabitants of the County of Salop, and of Oswestry especially, may rank among their most remarkable objects of attraction. While the Hill was being planted a small silver coin was found, which, on examination, proved to be of the reign of David I. of Scot180 
land. This, though not a direct link in the chain of proof of the title of Oswestry Castle to the honour it claims, and defies Scotland to dispute, is a remarkable corroborative incident, most valuable, as circumstantial evidence, in support of the claim. A stone has been placed on the Hill, with the following inscription :- 'A. D. MCXXXVIII., Walter, son of Alan, the progenitor of the Royal House of Stuart, left this, his ancestral castle, in the reign of Stephen, King of England, and of David I., King of Scots." "

The more recent history of the Castle may be given in a few words. In the sixth of Henry II., Guy le Strange, Sheriff of Shropshire, accounted in the exchequer for salaries paid out of the king's revenues to the wardens in the Castle of Blancminster (Oswestry), the inheritance of William FitzAlan, then lately deceased. In the fifteenth of John, the nephew (John) of the Earl of Pembroke, guardian of the Marches of Wales, was made Governor of Blancminster. In Henry III., John Fitz-Alan, as heir to Hugh de Albany, Earl of Arundel, had upon the death of that Earl, assigned for his purpatry, the Castle of Arundel, and upon paying $£ 1000$ fine was admitted to the possession of Oswestry Castle. In the twenty-fourth of Henry III., on the death of John Fitz-Alan, John le Strange had a grant of the custody of the lands of John, his son (then a minor), with an allowance of 300 marks per annum, for guarding Blancminster and other places. In the first of Edward I., John de Oxinden had the custody of the Castle of Blancminster, upon the death of John, Earl of Arundel. In the third of Edward I., Bogo de Knovil was Sheriff of the county, and Keeper of the Castle of Blancminster. In the eighth of Edward I., Isabel, mother of Richard, Earl of Arundel, had the custody of the Castle of Blancminster, and also of the hundred of Oswaldster during the minority of her son; but two years afterwards her brother, Edmund de Mortimer, supplanted her, and got the grant to himself. In the eighteenth of Edward I.2 Adam 


\section{OSWESTRY CASTLE.}

de Montgomery died Governor of the Castle. In the twenty, seventh of Edward I., Peter Meuvesine de Berwicke, juxta Akinton, died in the same office. In the twenty-seventh of Edward II., after the attainder of Edmund, Earl of Arundel, Roger Mortimer, Lord of Wigmore, had a grant of the Castle. In the twenty-first of Richard II., Richard, Earl of Arundel, being attainted or executed, the king seized upon his lands and manors, and granted them to William Scrope, Earl of Wiltshire. In the seventh of Henry IV., Thomas, son of the attainted Earl, after he was restored in blood, freed the burgesses from many impositions of the Constable of the Castle. Amongst the names of subsequent Governors of the Castle we find those of John Trevor, Vaughan, Jeffrey Kyffyn; and in the twenty-fifth of James I., Thomas, Earl of Suffolik, his wife, Lord Walden, Sir Arnold Herbert, and William Herbert, " grant to the Lady Craven, Sir William Whitmore, George Whitmore, and their heirs, the lordship, manor, and Castle of Oswestry." The state of the Castle in the Civil Wars has already been described.

In a record of the Inquisition, 21 Richard II., 1398, preserved in the Tower of London, there is a curious inventory of articles contained in Oswestry Castle on the attainder of Richard, Earl of Arundel, taken by order of the King, The Jurors consisted of inhabitants of the town and district. The record states, that " the Castle, Vill, and Lordship of Oswaldestre, in the Marches of Wales, is worth yearly, with its customs and appurtenances, besides the fees of all the officers there, and besides all reprizes made there, one year with another, $£ 252,16$ s. 2 d." $\quad * \quad * \quad * \quad * \quad *$ "That the said Earl was seized as of fee of one messuage in the Vill of Oswaldestre, by his deed enfeoffed one John ap Wyllym, to have to him and his heirs for ever, worth yearly beyond reprizes, 6s. 8d. Also, that the said Earl was seized as of fee of the advowson of the free Chapel of St. Nicholas, within the Castle of Oswaldestre, worth 46s. 8d. Also, that 
the said Earl of Arundel had within the Castle of Oswaldestre, on the 18th day of July last past, and afterwards, the following goods and chattels, that is to say,-in the Wardrobe there, 5 yew bows, 4 elm bows, 20 sheaves of arrows, 6 cross-bows, 5 lances, with 6 heads, 1 gun, 1 barrel of gunpowder, 200 quirells, 3 pol-axes, 2 sparthes, 3 broken jacks, 3 pair of gauntlets, 3 pallets, 1 banderich for a cross-bow, 1 table, 1 pair of stakes, 3 pair of fetters, 6 pair of iron handcuffs, with iron bolts, 1 coler, with 2 iron shakylls, 1 file, 1 hammer. In the Great Chamber, 1 cupboard, 2 tables, 4 forms. In the Middle Chamber, 3 chests, 2 forms, 1 table. In the High Chamber, 1 hand-mill, panel of a certain trefreget. In the Constable's Hall, 3 tables, four tressels, 3 forms, 1 bason, with a laver, 1 small chest. In the Butlery, 1 chest, broken at the top, 1 bucket, with an iron chain, 1 barrel for weapons, 31 keys of different locks. In the Chapel, 1 vessel for the holy water, 1 missal, 1 gilt chalice, 2 linen towels, with a frontal, 2 surplices, 2 chessibles, with accompaniments, 1 hand-mill for grinding corn. In the Kitchen, 1 stone mortar, with a pile of wood. In the Larder, 2 broken oxheads, with 6 bushels of salt; which said artillery, arms, goods and chattels, are put into the custody of Madog Lloid, the Deputy of Robert Legh, Chivaler Constable of the Castle aforesaid, for the defence of the same." After enumerating several other articles, the Inquisition record adds, "and in a certain house $i_{n}$ the Vill of Oswaldestre (the said Earl possessed) 601 fleeces of wool, weighing 2 sacks, and $\frac{1}{8}$ th of a sack, at per sack 100 s.; 50 gallons of honey, at $7 \mathrm{~s}$. a gallon. Also the said Earl had on the 18th day of July aforesaid, and afterwards, in the said Castle, 1 white stallion, price $£ 10$; 1 race-horse, called Young Sorrell, price $£ 13$ 6s. 8d. And in the Park of Oswaldestre Superior, 16 horse colts, 13 of which are 3 years old, and 3 of them 2 years old: price in the whole, $£ 6613 \mathrm{~s}$. 4d. The record further adds, that the said "Earl had after the 18th of July, $£ 720$ in money, and that one Thomas Harlyng, late Receiver-General of the said Earl, took and 183 


\section{THE WALLS.}

carried away the same, whereof he is answerable to the King." A great number of articles, with monies, cattle, \&c., are stated to have been taken away by various persons named, who are made answerable to the King for the same.-This document is curious, inasmuch as it throws some light upon the military weapons in use at the period, on the plain and scanty domestic articles in the Castle, and on the low value of farming stock, \&c. The record presents no account of the Earl's apartments, or those of his servants, or of the furniture there used. Probably all the valuable property which he possessed in the fortress was carried away and disposed of before the Earl was attainted. The entire record furnishes evidence of nothing polished or luxurious; on the contrary, it is a catalogue of mere rudeness, discomfort, and barbarity; giving no marks whatever of vice-regal grandeur or princely state.

As an additional fact it is proper to mention, that the BaileyHead was the original ballium, or quadrangle of the Castle; that the mount in the Castle-field, known by the name of the Cripple-bank, or gathe, was also the site of the ancient Barbican, or outer gate, at which the poor and diseased received relief. Of the free chapel, dedicated to St. Nicholas, infra Castrum de Oswaldestre, the advowson of which belonged to the Arundel family, there is not a trace left to mark its situation.

The sketch of Oswestry Castle which forms one of our illustrations shows that, in its pristine state, it was a formid. able structure, of great strength and stateliness. The architecture seems to be of the Saxon order.

\section{THE WALLS.}

The ancient Walls of the town were the work of Edward I., and no doubt were well and firmly built; but scarcely a vestige of them remains. Their circumvallation is, however, correctly marked in most of the old books, and old inhabitants of the present day point out various sites on which portions of the 


\section{ANCIENT HOUSES.}

walls stood. Edward was generally successful in giving strength and endurance to his military buildings. Caernarvon, Conway, and Rhuddlan Castles, all designed and erected under his superintendence, are noble fortresses in the present age, notwithstanding the dilapidations they have suffered from military attack and "Time's effacing fingers." The Walls of Oswestry must have suffered much injury during the period of the Commonwealth; and perhaps private encroachments since that time have been the principal cause of their entire disappearance.

\section{ANCIENT HOUSES.}

There are still remaining several ancient timber houses, to mark the architecture of bye-gone times. Among these are, the Three Tuns public-house, in Bailey-Street, and an antique edifice forming the angle of Bailey-Street and CrossStreet, in front of which is the figure of a spread eagle, raised on the plaster, and supposed to have been the residence of the Lloyds, of Trenewydd, who bore the eagle in their coat of arms. The Three Tuns was a popular house in former days, and was the resort of most of the drapers who visited the fairs and markets of the borough. Among the other old timber buildings are Miss Holbrooke's, in SalopRoad, the most attractive of any in the town, from the neatness in which it is kept, the Coach and Dogs, and the Fighting Cocks public-houses. These relics of past days may not be allowed to remain much longer, now that improvement in the town is likely to become so rapid in its strides.

The railway extension, from Oswestry to Welshpool and Newtown, will effect important changes in most parts of the borough; and as the antique relics to which we have been alluding are comparatively useless in a social point of view, their sites may soon be covered with buildings better adapted to the comforts and requirements of the present day. 


\section{ANCIENT RELICS.}

A ball found many years ago near the Cross in Oswestry, and now in the possession of W. Ormsby Gore, Esq., is considered to be one of the weights used at the end of beams in what was called Auncel Weight, practised in the reign of Edward I. It is ornamented with a shield, bearing the arms of England simply, which dates it before the 15th of Edward, as in that year he claimed the crown of France, and immediately, on obtaining it, placed the arms of that kingdom in the first quarter of his shield. On the second shield appears the bearing of the Fitz-Alans, a lion rampant. The third shield has an eagle displayed, most probably of the gentleman who at that period filled the office of Steward.

Some further antiquities require a brief notice. The field known by the name of Croft-y-Spytty, that is, the Croft of the Hospitallers, intimates that the Knight Hospitallers had once some establishment in the town. The field known as Erw-Spiridion, the Acre of Sprudion, or Syiridion, would lead to the conclusion that a church or chapel, or the ground itself, had been dedicated to the supposed Saint ycleped $S p i$ ridion. In a former part of this volume we have referred to Maes-y-garreg-llwyd, that is, the Plain or Field of the Sacred Stone. That plain is now divided into fields, situated on the Shrewsbury road, contiguous to Gallows-tree turnpike-gate. In the field nearest to the town there stands a Stone Pillar, about seven feet in height, and twelve in circumference; and in the field farthest from the town, there is a similar Pillar. The late Rev. Peter Roberts, the learned antiquarian, was of opinion that all the fields at that end of the town formed a large plain when these pillars were erected, and bore the name already mentioned, of Maes-y-garreg-llwyd. Llwyd was an epithet of the Deity, as in the expression "Duw llwyd," the Sacred God. Between these two pillars there is still visible part of a ditch, called the Devil's Ditch; and adjacent to the farthest field was another called "Caerychain Bannog," or the Field of 


\section{ANCIENT RELICS.}

the bossed Oxen. Mr. Roberts adds, " according to a tradition common in Wales, these oxen were twins, and employed by $H u$ Gadarn, a hero of antiquity, to draw a monster out of a lake, by which means he saved the country from being inundated. The popular tradition of the Devil's Ditch is, that an evil spirit formed it, in order to convey water to deluge the country, and that the ditch was in one night carried as far as Wynnstay, but that when the said evil spirit had carried it so far, the cock crew, he was obliged to desist, and it was left unfinished. Absurd, however, as these traditions may appear, they lead to the true origin, namely, that this ground and the pillars had some reference to the Deluge, and it may reasonably be presumed, that in the space included between these pillars some druidical rites were performed, in commemoration of the Deluge. 'The setting-up of a pillar, and consecrating it to the Deity, was a memorial of reverence to Him in the time of the Patriarchs, as we read in Genesis that Jacob set up a stone pillar, and consecrated it, in memory of his devoting himself to the worship of the true God. And hence it may be concluded, that these and such Pillars were in like manner the memorials-rude indeed, but durable-of Pagan tradition."

In the Shrewsbury Chronicle of March 16th, 1832, there appeared the following paragraph:- "As some workmen were digging in a field near Oswestry, last week, they turned up the hilt and part of the blade of an elegant antique sword. The blade is in two pieces, completely encrusted with rust, and very much corroded, but upon cleaning and grinding a part of it, the steel was found to be of excellent temper. The handle is apparently of ebony, or some similar wood, but encrusted with the oxyde which has passed from the steel inserted in it, and worked its way through the pores of the wood, so as to make it resemble buck's horn. The part of the sword which is attached to the hilt (about four inches in length) remains in the scabbard, and, what is very remarkable, the canvass of which the scabbard is composed is still visible. 


\section{ANCIENT RELICS.}

The scabbard and hilt are mounted with highly-chased silver, as perfect as when it came out of the hands of the graver. On the end of the hilt is an eagle, pouncing on its prey, and a representation of Jupiter and Leda. On each side of the guard is a full-length figure, and on the sides of the sword end of the hilt are the figures of a spread eagle, and of a doe couchant regardant. The latter appears as a crest. On the silver plate which covers the opening of the scabbard is the representation of an Arcadian Shepherd scene. The sword is of the description of those which were worn by the Cavaliers, and there can be no reasonable doubt but that it was dropped by one of them in the route to which the Royalist army was put by Sir Thomas Myddelton, when they made an attempt to regain possession of Oswestry, on the 2nd of July, 1644, after its capture by the Parliament forces. 'They had taken the passage of water,' says Sir Thomas Myddelton, 'near to Whittington, and very furiously assaulted and charged us, but were repulsed and forced to retyre, through the courage of our horse, who most courageously entertained the enemy. Three several times the skirmish was doubtful, either side being forced so often to retreat; but in the end, our foot forces coming up, relieved the horse, beat back the enemy, and pursued them with such force, that they put them to an absolute flight, in which we pursued them five miles towards Shrewsbury, to a place called Felton Heath, and where we likewise remained after their flight again, masters of the field. In the skirmish with the enemy, and in the pursuite we lost several of our horse, some of our troopers, but never a footman which I am yet informed of. As for the enemy, they lost many stout men; had many of them taken prisoners, some of them being of great quality, as the Lord Newport's eldest son, and besides in their flight, such was their haste, that we found in our pursuite, the highway as it were strewed with ammunition, \&c.' As this relic was found in the line of this pursuit, the road having passed through the field, there can be scarcely a doubt of its having belonged to one of the officers of Charles's army.". 188 


\section{OSWALD'S WELL.}

The sword is in the possession of Mr. Sabine, in whose field it was found.

In March, 1811, two urns were dug out of part of the Coney Green, belonging to the late Mr. Thomas Hilditch, of Oswestry. They were both of the same composition, but the larger one of a finer and more symmetrical form. In the smaller urn were found the remains of bones, but whether of the human form could not be ascertained.

A piece of marble, of an oblong form, and resembling an ancient club, was dug out of the ground at Broom Hall, in Oct., 1836, about five feet below the surface, in a bed of clay. It was one inch in thickness, but tapered to an edge all round, the broad edge being very sharp. It is supposed to have been a weapon of defence in the early British period.

\section{OSWALD'S WELL}

Is one of the most interesting objects of the town. It is beautifully situated to the west of the Free Grammar School, and has easy and pleasant approaches to it from Upper Brooks Street and from Willow-Street. The Well is supplied by a spring flowing from the elevated ground beyond it. It is inclosed in a small square basin, in a recess made of stone, and arched over. At the back there is a sculptured head of King Oswald, once "banded by a royal fillet," and formerly the front of the Well was secured by an iron grate. Tradition and superstition have invested the Well with much interest, but the purity of the water it sends forth should have secured to it a far higher celebrity. We are told that Oswald's remains were interred near the spring; that a tree was planted there to mark the spot; that when Oswald was slain, in the battle with Penda, an eagle tore one of the arms from the body, and, flying off with it, fell down and perished: on the spot from which the waters burst forth, and have continued to flow ever since, as miraculously as the waters of St. Winifred's Well, in Flintshire. A later writer or 189 


\section{OSWALD'S WELL.}

Border History has ventured to inform us, that so recently as the year 1780 King Oswald's "skull was found in digging the pool just below the Well." How the skull was identified the writer does not state, probably from the great difficulty he must have had in establishing such an important identification. Setting aside all this mystification and nonsense, we are glad to put on record, that the water from this Well is justly entitled to the appellation of pure aqua fontana; and from the analysis of Sir James Murray, which we subjoin, its medicinal properties are of no mean order:- "Thermometer at 470 Fahrenheit, the water consisting of sulphate of lime (gypsum), carbonate of lime, muriate of soda (common salt), muriate of magnesia, and sulphate of magnesia.-June 6th, 1822."

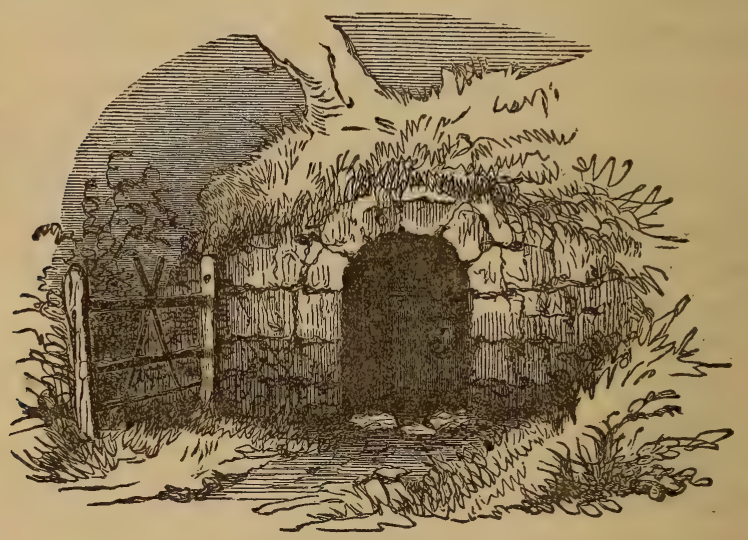

ST. OSWALD'S WELL.

It is generally admitted, from the records of the ancient historical writers, that on the spot where Oswald was slain a Monastery was founded, dedicated to him in the character of a Saint. It was called Blanc-Minster, or the White Monastery, and was situated according to Leland, "on the south side of the town." The time of the foundation or dissolution is not known, but its situation is fixed near the 


\section{ANCIENT CUSTOMS.}

site of the parish church, as some remains of the building are said to have been discovered in digging graves in the churchyard. A spot of ground near the church, still called Erw. Myneich, or Monk's Acre, would indicate that Blanc-Minster was contiguous to it. In the reign of Henry VIII., as we have already stated, Leland visited Oswestry, and noted that at that period "the cloister only was standing within the memory of persons then living."

Before closing this notice we would recommend all visitors to Oswestry to make a pilgrimage to Oswald's Well. The scenery around it is replete with beauty; and if the day be fine and warm, a draught of the water, which constantly bubbles up in freshness and pellucid clearness, will cheer and not inebriate. The inhabitants possess in this Well a valuable natural treasure which it is their duty to preserve, for their common benefit, free from all impurities and contaminations.

\section{ANCIENT CUSTOMS.}

In a work partly descriptive of the Border Lands of England and Wales, it might be deemed a reproach were we silently to pass by the customs that once prevailed in the district. Many of those ancient customs were innocent and harmless in their character, whilst others were connected with superstition which kept the people in mental darkness, and impeded the free course of education and knowledge. Our notice of these customs will be brief, for they are no longer observed in the town, and but slightly so, if at all, in the neighbourhood. The printing-press has exploded such folly, and most of the ancient customs will very soon, throughout our land, be referred to only as evidences of the ignorance of our forefathers, and their disregard of the educational improvement of their fellow-creatures.

Shrove Tuesday and its observances were vestiges of a Roman Carnival, when, as Aubanus tells us, "men eat and drank and abandoned themselves to all kinds of foolery, as if 


\section{ANCIENT CUSTOMS.}

resolved to have their fill of pleasure before they were to die." "Pancake Bell" is now unheard, because no sexton or bell-ringer can be found to pull the rope. Men and women do eat pancakes which, when well made, even Soyer would not object to; and such gastronomy is, we believe, the sum-total of Shrove-tide observances in the present enlightened day. Cock-fighting, bull-baiting, and other brutal amusements, formerly practised on this day, are abandoned, we trust; for ever.

Good FrIDAY is still observed so far, in reference to mundane things, that fathers and mothers indulge their children with a plentiful supply of Hot Cross Buns. This observance is harmless enough. The day being the anniversary of our Saviour's Crucifixion, it is now marked by the entire Christian community as one of solemn worship; and as time rolls on, and religious education prevails, we may reasonably expect that a still more derotional regard will be paid to this day.

EAster-Day is no longer observed by people walking into the fields early in the morning to see the "sun come dancing from the east." The Heaving or Lifting system, formerly much practised on Easter Monday and Tuesday, is now rapidly on the wane. By men and women not remarkable for their love of decency or modesty, it is still partially observed in Oswestry. The custom would, however, be "more honoured in the breach than the observance."

All Fools' Day (April 1) is, we believe, acknowledged by many of that class who are fond of a joke. The wit formerly displayed on this day consisted in sending persons on what are called sleeveless errands, for the history of Eve's mother, for pigeon's milk, and in quest of other absurdities. In the present day rude tricks are tried even upon philosophers, and with much gusto when they succeed. The "Verdant Greens," at this season of the year, are especially full-blown. 


\section{ANCIENT CUSTOMS.}

$\mathrm{MAY}_{\mathrm{Y}}-\mathrm{D}_{\mathrm{AY}}$ formerly brought with it flowery decorations in front of our house-doors ; but this pretty custom has long since faded away.

WALKING THE Boundaries.-A general custom formerly, but observed now in very few places. The Mayor, Churchwardens, Overseers, \&c., of Oswestry walked the boundaries in 1813 , and that was the last occasion of this ancient observance.

Palm Sunday, Maundy Thursday, Royal Oak Day, Corpus Christi Day, Oswestry Wake, All Saints' Eve, St. Swithin's DAY, \&c., have become, so far as rude observances are concerned, mere relics of past days. Our ancestors marked all these days with scrupulous attention; but few if any men of the present time have boldness enough to set them apart for rejoicing and merriment-for feast and carnival-as in days of yore. Gunpowder Plot (Nov. 5) is occasionally noticed by boys, discharging pop-guns, and alarming the lieges with bonfires, effigies, squibs and crackers ; but that absurd and bigoted observance is in its downward course, no one being interested in its continuance at present but the pyrotechnists, who tempt boys to spend their money in rockets, blue-lights, and other combustibles.

Christmas.-Some twenty years ago Christmas morn was ushered in with the singing of carols by "wakeful Waits," thus joyfully celebrating the opening of this truly-festive anniversary, and this custom is still partially observed. The singers of the Parish Church also greeted the inhabitants at their several dwellings with sounds of grateful melody. No longer is this latter custom maintained, but Christmas Day is marked as a sacred and solemn festival; " the rich and the poor meet together ;" on that day the conventionalities of rank and dignity are thrown aside; hospitality prevails in every house in the land, from the palace to the 


\section{RAILWAY COMMUNICATION.}

cottage; families are collected together to partake of that day's joyful festivity; and the nation at large presents the delightful picture of one happy family. The rich administer kindly to the poor, and all hearts are touched with benevolence or gratitude. Long may our merry Christmas-tides thus be observed; for such customs are based on true religion, whieh teaches men "to love one another."

\section{Liaillowan Communication.}

We need not enter into detail, now-a-days, to show how railway communication was rendered necessary a quarter of a century ago by the great increase of travelling throughout the land, and the insufficiency as well as inefficiency of stagecoach conveyance to satisfy the public wants. When railway travelling was first suggested stage-coaches had been "whipped-up " by "coming events " into improvement; the people were no longer compelled to "drag their slow length along," for full five wearisome days, from Chester to London. The "Gee-hos," and "Highflyers," at four miles an hour; "The Birmingham and Shrewsbury Long Coach, with six able horses, in four days;" even the "Flying Machine," from Snrewsbury to London in two days, had all passed the stage of their creeping existence; and the liege subjects of the realm were now beginning to be whirled along, at ten and tweive miles an hour, in "Quicksilvers," "Tantivys," "Eringo-braghs," "Tallyhos," "Wonders," and other well-horsed and well-appointed vehicles bearing equally excitable names. The Coach called "The Wonder" made the journey from Shrewsbury to London in a day. An intelligent contributor writes, - "The late old Justice Smith," in a conversation I had with him some 25 years ago, said, "I remember going to London 70 years ago by a coach called The Fly; we were 7 nights and 8 days on the road, and now they go in a day-what a man lives to see!" But even this increased "pace" did not meet the requirements of the community. James Watts' steam-engine had begun to revolutionize all classes 


\section{RAILWAY COMMUNICATION.}

and occupations. In manufactures, hand-looms, spinningjennies, shuttles, treddles, and the rest of early inventions were superseded by steam-power, moving machinery for spinning and weaving; in packet and marine conveyance generally 'Watts' steam-power wrought as great a change; and in the manufacture of metal and porcelain goods, the sawing of timber and stone, and even the making of pins and needles, steam was the great giant power. With this national revolution in trade, manufactures, and commerce, came a more active and enterprising spirit among the people; soft and hard goods, as the manufactures of the north and midland counties are technically called, were multiplied until supply exceeded demand; the locomotive wants and desires of the public increased; and all eyes and heads were turned towards Watts' steam-engine as the only mighty agent of accelerated travelling. The history of the country has supplied the results of this great experiment. The ever-honoured George Stephenson succeeded in carrying heavily-laden trains, of passengers and goods, on the Liverpool and Manchester Railway, at the rate of thirty miles an hour; and in the present day such is the appetite for rapid railway locomotion, that express trains, as they are called, flying over the earth at a more than race-horse speed of forty miles an hour, will scarcely satisfy the urgent requirements of manufactures and commerce.

Railway projects arose in various parts of the kingdom, and the first step taken towards what has since proved a direct communication with this borough and the metropolis was the incorporation of the Great Western Railway Company, by an Act passed in 5 and 6 of William IV. Some years elapsed before any measures were adopted to establish railway communication in this district. At length, in 1845 , when railway "bubbles and squeaks" "affrighted the isle from its propriety," a direct line was projected from Chester, through Whitchurch and Wem, to Shrewsbury. The scheme 


\section{RAILWAY COMMUNICATION.}

was promoted by the Chester and Holyhead Railway Com. pany, the London and Birmingham, and other important interests. Mr. Robert Stephenson was appointed engineer, and Mr. Mallaby, of Liverpool, solicitor, A Company, called the "North Wales Mineral Railway Company," had previously obtained an Act for making a line of Railway, from Chester to Rhuabon, and on the scheme for the line from the former place, via Whitchurch and Wem, being announced, a Company, in friendly connection with the North Wales Mineral Railway Company, and called the Shrewsbury, Oswestry, and Chester Junction Railway Company, was formed for the purpose of extending the Railway from Rhuabon to Shrewsbury, in opposition to the other scheme mentioned above. The late Mr, Henry Kelsall, of Chester, was appointed solicitor, and Mr. Robertson engineer. A sharp struggle between the rival Companies ensued, but at length the line from Chester to Shrewsbury, via Whitchurch and Wem, was abandoned; by the prudent interposition of $\mathrm{Mr}$. Edward Williams, solicitor, of Oswestry, (of the firm of "Longueville and Williams,") the dissentient landowners were appeased; and the "Shrewsbury, Oswestry, and Chester Junction Railway Company" obtained their Act, which passed through parliament as an unopposed Bill, the royal assent being given to it the 30th of June, 1845. W. Ormsby Gore, Esq., as Chairman of the successful line, rendered powerful assistance to its claims, having clearly seen the advantages which it must render to the important interests of North Shropshire. The next step was to unite the two lines between Chester and Shrewsbury, viz., the North Wales Mineral Railway, and the Shrewsbury, Oswestry, and Chester Junction, and an arrangement was accordingly entered into by the two Companies, by which, in 1846, they were united into one, under the title of "The Shrewsbury and Chester Railway Company." The subsequent history of this line is patent to the public; the battles of the Great Western Railway interest, with those of 


\section{RAILWAY COMMUNICATION.}

the North Western, each Company seeking to possess the line, almost rivalling in intensity the fierce struggles of the ancient Roses-York and Lancaster. In the Parliamentary Session of 1854 a Bill was brought into the House of Commons by Viscount Barrington, Lord Norreys, and Sir Phillip Egerton, to authorize the consolidation, into one Company, of the Great Western, the Shrewsbury and Birmingham, and the Shrewsbury and Chester Railways. The Bill was sanctioned by Parliament, and the Act is now cited for all purposes under the title of "The Great Western, Birmingham, and Chester Railway Section." By this consolidation of these several Companies a direct communication with London, under one system of Railway management, has been secured to the town of Oswestry; the journey by the Express Trains occupying no more than about five and a half hours. The country through which the Great Western line runs is remarkable for its beauty and interest. Windsor Castle, Oxford, Blenheim, Leamington, Warwick, and other attractive places, are in close proximity; and to add to these advantages, the care, attention, and able management of the entire line, are further agreeable features in the route, which all travellers on the railway gratefully acknowledge.

To the inhabitants of Oswestry and its vicinity it is unnecessary to say anything in praise of the attractive scenery that gives such lively interest to the railway between Shrewsbury and Chester. To the stranger, however, and the summer tourist in search of the sublime and picturesque, we may remark, that few lines in the kingdom present so many charms to the admiring gaze as this most delightful railway. Llangollen Vale has a world-wide celebrity; whilst the Chirk Viaduct, spanning the Ceiriog Vale; the pretty village of Chirk ; Lord Dungannon's pleasant seat at Brynkinalt ; "Chirk Castle walls;" Wynnstay Park ; the fine tower of Wrexham Church; Gresford Vale, with its luxuriant and refreshing scenery; and the graceful approach to Chester, across "Sweet 197 
Deva's wizard stream," and in sight of the animating races course (the Roodeye), the fine old Roman walls of the city, the ancient Castle, a work of Roman art, the Armoury, county Gaol, St. Werburgh's Cathedral, the venerable Church and Priory of St. John the Baptist,-these, with many other relics of days now

" Numbered with those beyond the flood,"

must give an intense interest to those who value objects stamped with natural beauty and hoary antiquity.

All hostility between the Great Western and North Western Railway Companies having, at least for the' present, ceased, both of these gigantic undertakings can, without ungenerous feelings one against the other, devote their energies and capital to the improvement of all departments of their respective undertakings, rendering to the public the attention, comfort, and assurance of safety in travelling which railway management ought to secure.

\section{EXTENSION LINE FROM OSWESTRY TO WELSHPOOL AND NEWTOWN.}

Whilst this volume was passing through the press a successful effort was made in carrying through Parliament a Bill for extending a line of railway through part of Montgomeryshire, commencing by a junction with the Shrewsbury and Chester Section of the Great Western Railway. The Bill was introduced into the House of Commons in the early part of the present Session of Parliament (1855), and passed through the various stages of that branch of the Legislature without opposition. In the House of Lords a siight but unsuccessful opposition was raised, and the Bill received the Royal assent on the 25th of June. Thus has been secured to the county of Montgomery, which is rapidly growing in population and importance, the advantage of railway com198 


\section{NEW EXTENSION LINE.}

munication direct from the metropolis, and from the busy seats of manufacturing industry in the north. The manufacturing and agricultural wealth and enterprise of Montgomeryshire, its rich mineral resources, and the benefits which will accrue to it by throwing open to its use the affluent coal-fields of Shropshire and Denbighshire, were strong claims entitling Montgomeryshire to the boon she sought. The further objects contemplated by the promoters of this line, in connecting it, at no far distant period, with the magnificent national harbour at Milford Haven, and thus opening a grand route from that capacious landing-place from the north of Ireland to Manchester, Yorkshire, and the Midland Counties, were doubtm less among the considerations of Parliament in granting their sanction to this railway. The line will commence by a junction with the Shrewsbury and Chester section of the Great Western Railway, at its Oswestry terminus, and then proceed by Llanymynech, Llandrinio, Llandisilio, and Buttington, to Welshpool; thence, crossing the river Severn, near Miltrewydd, will pass between Montgomery and Berriew, and on to Newtown, on the south side of the river, where it will unite with the Newtown and Llanidloes line.

The capital authorized to be raised by the "Oswestry and Newtown Railway Company" is $\mathbf{£ 2 5 0 , 0 0 0 . ~ M r . ~ B e n j a m i n ~}$ Piercy is appointed resident engineer of the line; and $\mathrm{Mr}$. Peter Barlow consulting engineer. The contractors for the making of the entire line are Messrs. M'Cormick and Thornton, whose previous railway contracts give the best assurance that the present line will be constructed in an efficient manner.

The first general meeting of the shareholders was held at the Town Hall, Welshpool, on Saturday, July 21 st; WiLliam Ormsby Gore, Esq., Chairman of the Board of Provisional Directors, in the chair. The attendance was very numerous. 


\section{FIRST RAILWAY MEETING.}

The report stated that it was the intention of the Directors to proceed with the construction of the railway with as little delay as possible, that the certificates of the proprietorship of the shares in the capital of the Company, under the seal of the Company, could be forthwith issued to the Shareholders; that the Directors congratulated the Shareholders and the district upon the unanimity which had prevailed in the establishment and progress of the Company, and expressed their hope that this would lead to the speedy completion of the undertaking, and the further developement of the resources of the country. The speakers on this occasion were the Chairman, Sir W. W. Wynn, Bart. M.P., the Rev. C. T. C. Luxmoore, the Ven. Archdeacon Clive, G. H. Whalley, Esq., the Rev. Maurice Lloyd, Richard Humphreys, Esq., George Brace, Esq., and other gentlemen. The Directors named in the Act were, William Ormsby Gore, Esq., M.P., Sir Watkin Williams Wynn, Bart. M.P., D. Pugh, Esq. M.P., John Naylor, Esq., John Carnac Morris, Esq., Richard Herbert Mytton, Esq., John Davies Corrie, Esq., Rowland Jones Venables, Esq., Arthur James Johnes, Esq., Col. Herbert Watkin Williams Wynn, M.P., J. Powell Wilding, Esq., and Wm. Lloyd, Esq., and they were re-elected unanimously. An important resolution was also passed, "That it is the opinion of this meeting, that it is of the utmost importance to the interest of the Company that a communication by railway should be effected between Newtown and Milford Haven; and the Directors are hereby requested to afford such co-operation and assistance to any Companies now existing, or which may be projected, as would best tend to accomplish that object." The entire proceedings were marked by harmony and good spirit, and all present appeared suitably impressed with the importance and value of railway communication through Montgomeryshire, and with the benefits, in connection with the great national harbour at Milford Haven, which would ultimately accrue to the "Oswestry and Newtown Railway Company." Few, if 


\section{STATISTICS.}

any, railway enterprizes were ever started under a more able and upright management, and perhaps equally few lines, of so short a distance, had at their outset such encouraging prospects before them. With these signal advantages no doubt can be entertained that the undertaking will be crowned with abundant success.

\section{Statistics.}

The Borovgh of Oswestry is situated on the north-west border of Shropshire, in the Diocese of St. Asaph, and Deanery of Marchia, and in the Hundred to which it gives name. In 1535, by a statute of Henry VIII., Oswestry, with Whittington, Maesbrook, Knockin, Ellesmere, Down, and Chirbury, was, by Act of Parliament, severed from Wales, and annexed to the County of Salop. The Hundred of Oswestry is bounded on the west by Montgomeryshire and Denbighshire; on the north by the rivers Ceiriog and Dee, and the stream of Shelbrook, which separates it from Denbighshire and Flintshire ; on the east by the Hundred of Pimhill; and on the south by the rivers Vyrnwy and Severn, which divide it from Montgomeryshire, and from the Hundred of Ford.

The Upper Division of the Hundred contains the parishes of

$\begin{array}{ll}\text { St. Martin, } & \text { Llanymyach (part of), } \\ \text { Whittington, } & \text { Llansilin (part of), } \\ \text { Selattyn (part of), } & \text { West Felton (part of), } \\ \text { Oswestry (part of), } & \text { Ellesmere (part of), }\end{array}$

LLANYBLODWEL,

and the extra-parochial places of Halston and Heath Farm.

The parish of St. Martin contains the townships of Ifton Rhyn (upper), Ifton Rhyn (lower), Weston Rhyn (upper), Weston Rhyn (lower), and Bronygarth (east and west). 


\section{STATISTICS.}

The parish of Whittington contains the townships of Whittington, Welsh Frankton, Old Marton (part of), Berghill, Daywell, Fernhill, Hindford, Henlle, and Ebnall.

The parish of Selattyn contains the townships of Porkington (upper), and Porkington (lower).

The parish of Oswestry contains the townships of Oswestry, Middleton, Aston, Hisland, Wooton, Sweeney, Weston Cotton, Maesbury, Llanvorda, Pentregaer, Cynynion, Coedtan y gaer, Treferclawdd, Treflach, Trefonen, and Crickheath. The parish of Oswestry contains also the township and chapelry of Morton, which are in the Lower Division of the Hundred.

The parish of Llanyblodwel contains the townships of Llanyblodwel, Abertanat, Blodwel, Bryn, and Llynclis, or Llunck-Llys.

The parish of Llanymynech contains the townships of Carreghofa, Llanymynech and Llwyntidman. The parish of Llanymynech contains also the township of Treprenal, which is in the Lower Division. The rest of the parish is in Denibighshire, and, for election and other purposes, is annexed to Montgomeryshire.

The parish of Ellesmere, in the Upper Division' of the Hundred of Oswestry, contains the townships of Dudleston (upper), and Dudleston (lower). The other townships in the parish are in the Ellesmere Division of the Hundred of Pimhill.

The parish of West Felton contains the townships of Woolston (part of), Sandford, and Twyford. The other townships in this parish, namely, West Felton, Sutton, Rednal, Haughton, and Tedsmere, are in the Lower Division.

The parish of Llansilin has only one township in Shropshire (Sychtyn). The rest of the parish is in Denbighshire. 


\section{STATISTICS.}

The Lower Division of the Hundred contains the parishes of

$\begin{array}{ll}\text { West Felton (part of), } & \text { Melverley (part of), } \\ \text { Knockin, } & \text { Oswestry (part of), } \\ \text { Ruyton, } & \text { Llanymyech (part of), }\end{array}$

KINNERLEY.

The parish of West Felton contains the townships of West Felton, Rednal, Sutton, Haughton, and Tedsmere, or Tedsmore. The other townships in the parish, namely, Woolston, Sandford, and Twyford, are, as already stated, in the UpPer Division.

The parish of Knockin contains only the township of Knockin.

The parish of Ruyton (of the Eleven Towns) contains the townships of Ruyton, Cotton, Shotatton, Shelvocke, Eardiston, and Wikey.

The parish of Kinnerley contains the townships of Kinnerley and Argoed, Dovaston, Kynaston, or Kinaston, Maesbrook-issa, Maesbrook-ucha, Edgerley, Tir-y-Coed, and Osbaston.

The parish of Melverley contains the townships of Melverley (upper), and Melverley (lower).

The parish of Oswestry, in the Lower Division of the Hundred, contains only the township of Morton.

The parish of Llanymynech, in the Lower Division of the Hundred, contains the townships of Carreghofa and Treprenal.

The Manors in Oswestry Parish are Aston, Duparts, and Middleton. Aston includes the townships of Aston, Hisland, and Wooton, and also Twyford, in West Felton parish. Duparts includes the township of Crickheath, 203 


\section{POPULATION.}

Cynynion, Llanvorda, Maesbury, Morton, Pentre-gaer, Sweeney, with Weston Cotton, and the township of Sychtyn, in Llansilin parish. Middleton includes the township of Middleton, and Oswestry the town and liberties of Oswestry. Lady of the Manor for Aston, Mrs. Lloyd; and Lord of the Manor of Oswestry and Duparts, the Earl of Powis.

\section{POPULATION.}

The population of the town and parish, in 1801, amounted to 5,839 ; and the number of houses, 788. In 1811 the population of the town and parish had increased to 6,733 . In 1821 the returns showed that the population of the town and parish was still on the increase, the number of males and females being 7,523. The population of the town and liberties, in June, 1831, was-males, 2,007; females, 2,471; total, 4,478. The return further showed that the number of houses in course of being built, was 3 ; houses uninhabited, 29 ; ditto inhabited, 885 ; families engaged in agriculture, 11 ; in trade, 276 ; all others, 613 . Total number of families, 899. Male servants, 42 ; females, 311 ; retired tradesmen, 38 ; clergy, educated men, \&c., 79; handicraft, 567 ; gardeners, \&c., 232. The returns for 1841 were as follows; - Town and Liberties, 4,569 ; Parish, 4,277; total, 8,846. Houses occupied in the town, 931 ; unoccupied and building; 68 ; in the parish, 886 ; unoccupied and building, 18. In 1851 the census returns were as follows :-

$\begin{array}{rcr}\text { Males. } & \text { Females. } & \text { Total. } \\ \text { Town and Liberties ......2,251 } & 2,565 & 4,816 \\ \text { The Parish } \ldots \ldots \ldots \ldots \ldots . . .1,972 & 2,006 & 3,978 \\ \text { Total.............4,223 } & \overline{4,571} & \overline{8,794}\end{array}$

\section{AGRICULTURAL STATISTICS.}

A return was made in 1854, giving the following details on agriculture, in reference to Oswestry Town and Liberties, Oswestry Parish, and other parishes within the Hundred:204 
The total number of acres occupied in the Town and Liberties of Oswestry, the Parish of Oswestry, Llansilin, Llanyblodwel, Selattyn, Llwyntidman, Sychtyn, St. Martin's, Chirk, Whittington, Felton, Ruyton, Knockin, and Kinnerley, was 78,301; sown with wheat, 7,909 acres; with barley, 6,512; oats, 2,924 ; rye, $39 \frac{3}{4}$; beans and peas, 275 ; vetches, 160 ; turnips, 4,420 $\frac{1}{2}$; mangold, $48 \frac{1}{4}$; carrots, 24 ; potatoes, 566 ; flax, 5. Total under tillage, 24,013; clover, lucerne, and other artificial grasses, $6,307 \frac{1}{4}$; permanent pasture, 3,198;

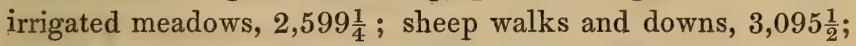
total under grass, 63,990 ; number of acres in houses, gardens,

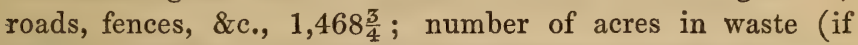
any) attached to the farms, 2,258; horses, 2,618; colts, 802 ; milch cows, 6,854 ; calves, 5,571 ; other cattle, including working oxen, 4,636; tups, 588; ewes, 12,509; lambs, 9,047 ; other sheep, 4,572; swine, 7,142; number of acres in wood and plantations, 3,749; common lands, 227.

The greatest registered quantity of wheat, according to the excise returns, ever sold in one day at Oswestry market, was disposed of on Wednesday, the 11th of July, 1855, namely, 4,373 imperial measures.

\section{Watural 鼠istorn.}

Our limits will not admit of extended observation on this subject, but it is our duty to direct the attention of our readers to the feathered tribes in the district, which include many of the more remarkable and beautiful of British birds. Mr. Cross, of Oswestry, has, in the last few years, made collections of rare and valuable birds, some delightful songsters, including the nightingale, the piping bullfinch, with birds of prey, those of the passerine order, and a large variety of water birds. The following list, formed more than twenty years ago, the names given according to Bewick's history of birds, will show that the neighbourhood has long abounded with fine specimens of the feathered creation :- 


\section{NATURAL HISTORY.}

Kites.-Ring-tailed eagle, osprey, common buzzard, honey buzzard, kite, goshawk, sparrow-hawk, hen harrier, kestrel, and marten.

Owls.-Great-eared owl, white owl, and tawny owl.

Butcher Birds.-Great ash-coloured shrike, red-backed shrike.

Pies.-Raven, carrion crow, hooded crow, rook, jackdaw, magpie, jay, starling, ring ousel, ousel cock or blackbird, missel thrush or storm cock, fieldfare, throstle or thrush, redwing, cuckoo, and wryneck.

Woodpeckers.-Green, greater spotted, lesser spotted, nuthatch, and creeper.

Grosbeaks.-Grosbeak or hawfinch, green grosbeak, bullfinch, pine grosbeak.

Buntings.-Brown, yellow hammer, blackheaded or reed sparrow, and snow bunting,

Finches.-House sparrow, mountain sparrow, chaff, or pied-finch, mountain-finch, gold-finch, linnet, and lesser redpole.

Larks.-Sky-lark, field-lark, grashopper-lark, woodlark, and tit-lark.

Wagtails.-Pied, or water wagtail, grey, and yellow.

Flycatchers.-Pied, or gold-finch, spotted, or house linnet.

Warblers.-Robin redbreast or ruddock, redstart or brantail.

Fauvette.-Lesser fauvette, winter fauvette or hedge sparrow, reed fauvette, black-cap, white-throat, yellow willow wren, willow wren, least willow wren, wren, golden-crested wren, white rump or wheat ear, win-chat, or gorsehopper, stonechat, and nightingale. 


\section{NATURAL HISTORY.}

Titmice.-Greater, blue or tom-tit, cole, marsh, long* tailed, or can-bottle.

Swallows.-Chimney swallow, marten, sand marten, swift or deviling, night jaw or fern owl.

Doves.-Wild pigeon, ring dove, turtle dove, and small black rock pigeon.

Gallinaceous.-Domestic cock, pheasant, turkey, peacock, pintado or guinea fowl, wood grouse, black grouse, red grouse, partridge, quail, corncrake or landrail.

I'lovers.-Great plover, pee-wit or lapwing, golden plover, and grey plover.

WATER Birds.-Long-legged plover, water crake, or rail, water ousel, and kingfisher or haleyon.

Herons.-Heron, bittern or bog-boom, and curlew.

Snipes.-Woodcock, great snipe, common snipe, and judcock, or jacksnipe.

Godwit.-Brown sandpiper, common sandpiper, water, or moor hen, coot, greater coot, great crested grebe, little grebe, or jack doucker.

Terns.-Common and lesser.

Common gull.

Ducks.-Wild swan, swan goose, grey-lag goose, tame goose, mallard, or wild duck, shieldrake, widgeon, and teal.

Pelicans.-Cormorant,-pelecanus graculus, or the shag.

The district has occasionally other aërial visitants, including the peregrine falcon, the bird which furnished the ancient amusement of falconry, the colymbus troile, or guillemot, and the corvus caryocatactes, or nutcracker. 


\section{NATURAL HISTORY.}

Mr. Cross's specimens are of recent date, many of the birds named having been taken during the last twelve months. We subjoin his list, which will be read with interest by all lovers of natural history :-

Peregrine falcon, kite, buzzard, goshawk, blue hawk, merlin, hobby, sparrow hawk, kestrel, large butcher bird, small butcher bird. Tawny owl, white owl, longeared owl, short-eared owl, night jay or goat suckercuckoo. Green woodpecker, great spotted woodpecker, lesser spotted woodpecker, nuthatch, creeper. Wood pigeon, rock pigeon, coblard turtle, turtle dove. Rook, crow, jackdaw, magpie, jay, starling, black bird, wood thrush, thrush, fieldfare, red wing, stone chat, whin-chat, yellow hammer, mounting finch, red finch, gold-finch, bull-finch, robin, reed sparrow, hedge sparrow, common sparrow, green linnet, grey linnet, yellow wagtail, pied wagtail, red start, black cap, pied flycatcher, spotted flycatcher, white throat, black cap titmice, small black cap titmice, blue cap titmice, long tailed titmice, willow wren, common wren, golden crested wren. Swift, barn swallow, house marten, sand marten. Woodlark, skylark, meadow pipit, tree pipit. Pheasant, grouse, partridge, black grouse, corncrake. Heron, bittern, cormorant, eared grebe, goosander, smews, curlew, widgeon, silver widgeon, magpie widgeon, golden eye widgeon, pintail duck, coot, moorhen, jack curlew, teal, seagull, woodcock, solitary snipe, common snipe, small grebe, lapwing, grey plover, golden plover, jack snipe, water rail, ring ouzel, water ouzel, marsh sandpiper, common sandpiper, knot, and kingfisher. 


\section{新iturtr.}

\section{ANGLING.}

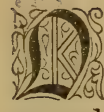

SSWESTRY has no rivers immediately contiguous to it, but at short and easily-approachable distances are several, namely, the Severn, the Vyrnwy, the Tanat, the Dee, the Ceiriog, the Perry, the Morlas, and the Morda. The Severn has its rise from a small lake, on the eastern side of Plinlimmon, whence it flows in a devious direction, under the Welsh name of Hafren, to Newtown, whence it assumes its English name of Severn, and pursues its circuitous route to Shrewsbury. From its source to fair Salopia it runs nearly one hundred miles, receiving the waters of several tributaries. From Shrewsbury it continues its winding course, and receives the Tern, at the foot of the Wrekin, about which it describes a semi-circle; then curving repeatedly, it flows towards Coalbrookdale, whence it flows in a north-west direction to Tewksbury, and eventually to the British Channel. Blakey, in his recently-published volume on " Angling," says, "The best bottom-fishing for carp, perch, roach, chub, and eel, is within those portions of the river appropriated to navigation. Grayling are to be met with in many parts of the Severn." The Vyrnwy and Tanat abound with fish; the former so much so that it has obtained the title of Piscosus Amnis. The Tanat falls into the Vyrnwy at Aber-Tanat, and the Vyrnwy into the Severn at a place called $Y$ Cymmerau (the Conflux), at the lower end of Guilsfield 209 


\section{RIVERS-ANGLING.}

parish, not far distant from the Breiddin, Moel y Golfa, and Cefn y Castell mountains. The scene in this district has been sung in rapturous and beautiful strains by a Welsh bard and warrior, of the 12th century (Gwalchmai) :-

" Rise orb of day! the eastern gates unfold, And shew thy crimson mantle, fring'd with gold;

Contending birds sing sweet on every spray,

The skies are bright-arise, thou orb of day!

I, Gwalchmai, call-in song, in war renown'd,

Who, lion-like, confusion spread around,-

The live-long night the Hero and the Bard,

Near Breiddin's rocks, have left a constant guard,

Where old transparent streams in murmurs glide,

And springing grass adorns the mountain's side,

Where snow-white sea-mews in the current play,

Spread their gay plumes, and frolic through the day!"

Blakey furnishes some practical information on this branch of our notice. He says :- "The Vyrnwy has a great number of dependent feeders, the principal of which are the Eunant, the Afon, the Gedis, the Afon Gynnan, the Glasgwn, and the Cown. These undoubtedly constitute a considerable range of the waters, and are well adapted for the fly, and some for trolling as well. After the main river receives all these tributaries, it flows a south-eastern course for twenty miles, and then receives the waters of the Twrch, which flows a distance of twenty miles, through a very interesting section of the country. This tributary itself has good angling feeders, capable of affording fair sport with the rod. The Vyrnwy likewise receives the Cain, and, a little farther down, the Tanat, both of which contain good fish. The Tanat itself is fed by several good streams, as the Rhaiadr, the Afon Harrog, and the $Y$ mrch. Here there is good fly-fishing. All these waters, large and small, are bright, sparkling, and flowing, and have that peculiar form of stream which indicates good sport. As to the colour of the fly requisite in these mountain streams, little need be said; in fact, when the fish 210 


\section{RIVERS-ANGLING.}

are in humour, and they are not here capricious, they seem to snatch at anything in the shape of an insect. Very large flies, however, will not answer well."

The Dee has its origin in Merionethshire, by the junction of two small streams rising about four miles to the north-west of Llanwchllyn, and two miles below that village enters Pimblemere, or Bala Lake (Llyn Tegid); issuing from that, beneath Bala, it flows under the bridge, takes a north-easterly direction through the Vale of Eideirnion, and turning to the east in fine meandering curves, waters the Vales of Glyndwrdwy (Vale of the Dee), and Llangollen, where it receives the tributary Brân. Thence, passing through Llangollen Vale, beneath Pont-y-cysyllte Aqueduct, and the Great Western (Shrewsbury and Chester) Viaduct, both of which span the Vale, it curves below Wynnstay Park, emerges into the Vale Royal of Cheshire, and finally, after passing through Holt, and skirting Eaton Hall, the magnificent seat of the Marquis of Westminster, glides past the Church of St. John the Baptist, in Chester, beneath the ancient and new bridges and railway viaduct there, and finally, at the estuary of the Dee, enters St. George's Channel. The portion of the Dee running through Denbighshire and Flintshire (not far distant from Oswestry,) is an excellent locality for trout-fishing, as the well-supplied dinner-tables of the two hotels in Llangollen (the Hand and the Victoria) can amply testify. The Ceiriog, the Perry, the Morlas, and the Morda, are each well stored with fish, and can supply the angler with tempting rewards for his patience and skill. The Lake of Llynclys, near Oswestry, has not only a poetical, but a piscatory celebrity also. It is the scene of a clever ballad, from the pen of the poet Dovaston, who, as a prefix to his metrical tale, has given the following description of the Lake:- "Llynclys Pool is a small but beautiful lake, of extraordinary depth, on the Welsh border, near Oswestry. The name in the Welsh signifies Sunk Palace, and the vulgar have a firmly-believed 
superstition (in which the neighbourhood abounds), corresponding with the catastrophe of this ballad; nay, some even at this day go so far as to affirm, that when the water is clear and the surface smooth, towers and chimneys may be seen in it at a great depth. In the summer months fishing parties of ladies and gentlemen frequently spend the day on it in a boat with music and refreshments; on one of these occasions this ballad was hastily written." The Lake is situated near the turnpike-road from Oswestry to Welshpool, only a short distance from Llynclys turnpike-gate. It is bordered on some of its sides with reeds and rushes, and a few years ago the flower of a white water lily was pulled up, not far from the shore, the stalk of which measured nearly fourteen feet. The fishery is the property of the Earl of Powis, and the water abounds with pike, bream, perch, and dace. R. H. Kinchant, Esq., of Park Hall, near Oswestry, has a]so an interest in the fishery.

The Ceiriog, a picturesque and romantic river, winds among the rocks behind Oswestry, forming deep glens and dingles, and falls into the Dee below Chirk. The Perry and Morlas are two bright rivulets arising in the mountains near Selattyn; the former passes Whittington and falls into the Severn, near Fitz, whilst the latter unites with the Ceiriog, near Pont-yblew. The Morda, no inconsiderable stream, finds its rapid way between the rocks at Llanforda, immediately above the town of Oswestry, and, sweeping its course to the south, falls into the Vyrnwy at Pentreheylin.

The following metrical instructions to the student angler, although the lines are quaint, may not be deficient of interest to the younger disciples of Isaac Walton:-

"In deep the silver Salmon loves to rove;

And marly swifts allure the Barbel drove;

Sharp streams delight the Trout, still deep the Bream;

The fearful $C h u b$, he loves the shaded stream. 212

In shady holes and hollow banks, the Perch he dwells, 


\section{BOTANY.}

And, for his boldness, the finny race excels ;

Roach and Dace the sandy bottom choose,

And Carp the weeds, and Tench the muddy ooze.

In streams with gravel bottom Gudgeons do delight,

The wanton Bleak will ever sport in sight;

The Pike, the tyrant of the finny brood,

Near weeds and ledge lies lurking for his food."

\section{Botany of the 担arishy.}

We are indebted to the Rev. Thomas Salwey, Vicar of Oswestry, for the subjoined interesting paper on the Botany of the Parish. It gives evidence of his ardent attachment to this pleasing branch of Natural History, and its publication may lead others to follow his example, in studying a science which delightfully leads the mind of its possessor to an increased admiration of the beauty and wisdom of the Creator's marvellous works :-

"By cooling streams and softening showers

The vegetable race are fed;

And trees and plants, and herbs and flowers

Their Maker's bounty smiling spread.

The flowing tribes all blooming rise

Above the faint attempts of art;

Their bright inimitable dyes

Speak sweet conviction to the heart."

"The interest and variety of the Botanical productions of any district will always be found to depend upon its geological character; and in this respect there are perhaps few Parishes which comprise within their boundaries so many different geological formations as that of Oswestry. The lower part of the Parish, from the neighbourhood of the Town to the Queen's Head, consists of the new red sandstone; or rather to that part of it which is called by modern Geologists the Permian formation, and which is so called because this formation is most amply developed in the District of Perm, in Russia. The Town itself is situated upon the coalmeasures. With this is associated the usual sandstone grit and 


\section{BOTANY.}

chert, breaking out in Sweeney Mountain and Mynydd-yMyfyr. Immediately at the back of these hills the mountain, or carboniferous limestone, breaks out, running in a line through the parish from Cynynion, through Pentregaer, Trefonen, and Treflach, to Porth-y-waen. This is here and there broken through by detached masses of Trap Rock, as at the point on which the Tower of Pentregaer is built, and upon the western slope of the Moelydd; whilst on the slope of the hill from Cynynion, and under Coed-y-Coch, the Silurian system begins to shew itself. In such a district we may reasonably expect a corresponding variety of plants. In the following list, however, it is by no means intended to give anything like a complete enumeration of the plants to be found within the district, which would be inconsistent with such a publication as the present. Such plants only have been selected as will show the character of the Botany, and be a sufficient guide to any Botanist in conducting his researches.

"Great, however, as is the variety of Greological formation within the Parish, there is one feature, always of the greatest interest to the Botanist, which unfortunately it does not possess, namely, old woods, with their ancient oaks, the growth of centuries, and the deep mossy dells which are so favourable to the production of the scarcer cryptogamic plants. We have no scenery of this kind in our Parish, or even in the immediate neighbourhood, and hence our mosses are only those which are found everywhere. The beautiful little Dicranum bryoides (the moss which so revived the spirit of the unfortunate Mungo Park when fainting in the deserts of Africa), may indeed be found in Broom Hall lane; and the Hypnum commutatum may be gathered at the foot of the Moelydd. The Bryum palustre may also be found above Morda pool; and the Bryum roseum, and the large and handsome Bryum ligulatum, in some of the wet and shady lanes in the upper part of the Parish; but beyond these I am not aware that there are any mosses of peculiar interest to be found amongst us. We have, however, a greater variety of 214 


\section{BOTANY.}

ferns than perhaps any other district of equal extent could produce; but here again only the more scarce ones are enumerated,

"The more minute cryptogamic plants, and especially those under the head of Fungi, will of course be the least interesting portion of the list; but any notice of the Botany of the district would be incomplete without the introduction of a proportionate number of these obscure, but, to a Botanist, highly-interesting plants,

"The following are some of the plants which will be found in the parish, or close to its immediate boundaries:-

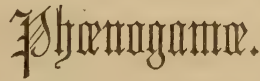

Circoea lutetiana-Penylan and Llanforda lanes

Scirpus lacustris--Llynclys pool.

Arundo phragmites-Llynclys pool *

Myosotis collina-Hedge banks about Pentreshanel.

Anchusa sempervirens-Croes-wylan, and Llanforda lane.

Menyanthes trifoliata-Bog above Morda pool.

Campanula trachelium-Hedges between Cynynion, and Pentregaer.

Viola hirta-Limestone rocks, Trefonen.

Artropa Belladonna--Porthywaen.

Gentiana amarella-Moelydd.

, campestris-Ditto.

Parnassia palustris-Meadows between Sweeney and Morton; and in a field on the west side of the Brick-kilns, at the High Vawr.

Galanthus nivalis-Upon the ledge of a low rock on the west side of Sweeney mountain.

Allium ursinum-Lanes and moist places about the upper parts of the Parish; and in the Nant-Mawr.

Colchichum autumnale-Meadows at Sweeney and elsewhere.

Paris quadrifolia-Thickets about Treflach.

Adoxa moschatellina-Broom Hall lane; Penylan lane; and other places.

Chrysosplenium alternifolium-Near the mill at Llanforda; and in other similar wet places.

," oppositifolium-Ditto.

Saxifraga tridactylites-Walls about the Town; and rocks at Pentregaer and Craig-y-Rhu.

* This reed is used extensively in Cambridgeshire, and the fen districts, for thatching, It has been known to last in this way for 100 years.

215 


\title{
BOTANY.
}

Cotyledon umbilicus - In the lane below the Race-ground, on the east side, Sedum anglicum-Rocks below Coed-y-coch; and between Craig-y-Rhu and Cynynion.

Prunus padus-Below Penylan mill.

Pyrus aria-Craig-y-Rhu.

Rosa villosa-Pentregaer.

Tilia parvifolia-Croes-wylan lane.

Cistus helianthemum-Rocks at Trefonen, above the Nant-Mawr.

Aquilegia vulgaris-Thickets at Treflach, where it is also found with white flowers.

Ranunculus parviflorus-Not uncommon on hedge banks; Maesbury road, near the Gallows-Tree Bank.

Trollius europaus-Fields in the upper part of the Parish; and below the house at the Hayes.

Teucrium chamedrys-This was found some years ago upon an old wall (since taken down) at the Hayes. It may be found now upon the wall of a garden in Brook-Street, lately belonging to the Vicar, having been transplanted there from the Hayes. It grows also. sparingly upon the old walls of Whittington Castle.

Scrophularia vernalis-Penylan and Llanforda lanes; brought there probably by the celebrated naturalist, Mr. Lloyd, who lived formerly at Llwynymaen.

Hutchinsia petrca-Pentregaer and Trefonen; upon the slope of the hills facing Llansilin.

Arabis hirsuta-Pentregaer.

Geranium colum binum-Hedge banks, occasionally.

Fumaria claviculata-Craigforda.

Ornithopus perpusillus-Moelydd, and Pentregaer.

Anthyllis vulneraria-Treflach, and Trefonen.

Tragopogon pratensis-Llanforda (1st park).

Tussilago petasites-Meadows near Llwynymaen.

Hieracium paludosum-Maesbury.

Achilloe a ptarmica-Upper part of the Parish.

Listera ovata-Road-side near Mount Sion.

Myriophyllum spicatum-Pool at Llanforda.

Typha latifolia-Morda, and Llynclys pool.

Carex paniculata-Llynclys pool.

" hirta--Llanforda

\section{Criyptugntmitr.}

\author{
F I L I C E S.
}

Polypodium phegopteris-Craigforda.

216 


\section{BOTANY.}

Aspidium oreopteris-Ditto.

Grammitis ceterach--Crickheath Hill and Treflach Hill, above Porthywaen and Blodwel rocks

Cystea dentata-On the loose heap of stones below the Tower at Pentregaer; also upon a high wall, at the back of the house, at Broom Hall.

Hymenophyllum Wilsoni-Upon a rock in a wood at Treflach.

Osmunda regalis-Maesbury.

Botrychium lunaria-In the 1st park at Llanforda; and on the brow of the

hill between the tower at Pentregaer and Craig-y-Rhu.

Ophioglossum vulgatum-Fields about Llanforda and Llwynymaen.

Equisetum limosum--Morda.

" fluviatile--Maesbury.

\section{U S C I.}

Dicranum bryoides-Broom Hall lane.

Bryum palustre-Above Morda pool.

" roseum-Wet and shady lanes in the upper part of the Parish.

, ligulatum-Ditto.

\section{LICHENES.}

Calicium furfuraceum (Coniocybe Fries)-Upon the hedge bank of the

Vicar's field on Cyrn-y-bwch.

Opegrapha chevallieri-Craigforda.

$$
, \quad \text { saxatilis-Ditto. }
$$

Lecanactis lyncea-Llanforda.

Spharopharon coralloides-Craigforda.

", b. caspitosum-Ditto.

Endocarpon miniatum-Ditto.

" late-virens-Mynydd-y-myfyr.

, rufo-virescens-Craigforda.

Verrucaria plumbea-Pentregaer, and Craig-y-Rhu,

, gemmifera-Craigforda.

" umbrosa-Ditto,

, codonoidea-Craig-y-Rhu.

, immersa-Craigforda.

" epipoloea-Treflach, Trefonen, and Craig-y-Rhu.

Pyrenothea leucocephala-Park Sychant.

Variolaria conspurcata-Limestone rocks, Craig-y-Rhu.

" globulifera-Upon an old ash tree at Craig-y-Rhu.

Urceolaria calcarea-Limestone rocks, Pentregaer.

Lecidea morio-Upon the loose stones under the Tower at Pentregaer.

, lapicida-Mynydd-y-myfyr.

" premnea-Upon an old oak in Middleton lane. 217 


\section{BOTANY.}

Lecidea griffithsia-Treflach, near Woodhill

", aromatica-Wall in Llanforda lane, just under the house.

פ, enteroleuca-The saxicolar form-same habitat as above.

"synothea-Upon an old gate-post near Treflach Hall.

, immersa-Limestone rocks, Pentregaer.

" pruinosa-Wall in the lane below the house at Llanforda.

"speirea-Limestone rocks, Pentregaer.

", incompta-Elm-trees in the Church-yard at Oswestry; and upon a wych elm at the Hayes.

" canescens-Occasionally found about Oswestry; but not common.

"quernea-Pentreshanel and Llanforda.

" oeruginosa-Upon an old gate-post, Treflach Hall.

"quadricolor-Mynydd-y-Myfyr.

"rupestris-Limestone rocks, Moelydd, \&c.

, pineti-Llanforda (scarce).

, lutea-Llanforda.

,, polytropa-Mynydd-y-myfyr.

" lucida-Pentreshanel, and other places.

" erythrella-Llanforda.

", coeruleo-nigricans-Moelydd.

Lecanora rubra-Craig-y-Rhu (very scarce).

, hamatomma-Craigforda.

, crassa-Moelydd and Craig-y-Rhu.

, candicans-Pentregaer.

, repanda-Pentregaer.

Parmelia glomulifera-Upon a single tree in Llanforda (2nd Park).

, Borreri-Upon oak trees opposite to the house at Woodhill.

, conspersa-Craigforda.

, pityrea-Upon a decayed oak near Old Port; and upon trees opposite to the house at Trafalgar.

, aquila-Mynydd-y-myfyr, upon a single isolated piece of rock on the south end of the hill. This is a very unusual habitat for this plant, which is usually a marine lichen.

, casia-In fruit; but rarely at Pentregaer and other places.

Sticta pulmonaria-Pentregaer.

Collema fragrans-Llanforda and Pentregaer.

, ceranoides-Llanforda and Pentregaer.

" multipartitum-Moelydd.

, marginale-Pentregaer.

, tunoeforme-Pentregaer.

, dermatinum-Pentregaer.

, muscicola-Pentreshanel.

Peltidea scutata-In fruit upon ash trees at Pentregaer. 


\section{BOTANY.}

Peltidea aphthosa-Craigforda; at the bottom of the wood a little above the brook (scarce).

, spuria-Upon a hedge bank, near Aston.

Gyrophora polyphylla-Mynydd-y-myfyr (scarce).

Borrera furfuracea-Mynydd-y-myfyr.

Cenomyce coespititia - Craigforda.

Cornicularia aculeata-Craigforda.

\section{CHARACC E.}

Chara hispida-Ditches above Morda Pool.

\section{ALGÆ.}

Ulva calophylla-Walls of Oswestry church; east end and lower part of the wall in the great walk; but not found every year.

" crispa-Oswestry church-yard; and other places about the town.

Lemania fuviatilis-In the Morda.

Zygnema nitidum-In the lane by the cottage at Porkington.

Batrachospermum moniliforme-In the well at Pen-y-lan; and in other places near the Morda.

Draparnaldia plumosa-In the Morda, below Penylan bridge.

Meloseira varians-In the Morda, below Craigforda, and below Penylan bridge.

Fragilaria hyemalis-In the Morda, below Craigforda.

Diatoma vulgare-In the Morda.

., flocculosum-In the pool, in the wood, at Llanforda.

Meridion circulare-In the well at Penylan; and in a ditch near the Morda, above Morda pool.

Cymbella minor-Penylan mill.

\section{FUNGI.}

Agaricus rubescens-In the shrubbery at Porkington.

, cristatus-Craigforda.

", phyllophilus-Craigforda.

", laccatus-b. amethystinus-Craigforda.

, clavus-Blodwel woods.

" galericulatus-Llanforda.

, stellatus-Llanforda (rare).

, disseminatus-Near the Lawnt.

Cantharellus cibarius-By the lower pool, at Porkington.

Dedalea betulina-In a timber yard at Oswestry.

Polyporus sulphureus-On the yew trees in the church-yard, at Oswestry;

but not found every year.

, salicinus-On stumps of trees, near Penylan mill. 


\section{BOTANY.}

Polyporus abietinus-On fir poles at Treflach.

" scoticus-Llanforda, in the wood above the garden.

" incarnatus-Upon broom by the pool in the wood, at Llanforda.

Fistulina hepatica-Upon a Pollard oak, at Penylan.

Thelephora purpurea-Llanforda.

Thelephora quercina-Llanforda.

" lactescens-Llanforda.

, incrustans-Upon an old felled trunk below Penylan Bridge.

, incarnata-On laburnum in the wood, by the pool at Llanforda,

Clavaria rugosa--Llanforda.

Peziza reticulata--Penylan.

" aurantia--Upon the stump of a tree near Trafalgar.

, humosa--Upon an old mossy trunk at Llynclys pool.

, anomala--Llanfurda.

" cyathoidea-On stems of herbaceous plants, Oswestry.

, cinerea-On fallen branches, Oswestry.

Bulgaria sarcoides-On an old stump at Llanforda.

Exidia glandulosa-Llanforda.

Namatelia encephala-On larch and fir rails in Llanforda park (scarce).

Sclerotium scutellatum-On oak leaves at Llanforda.

Phallus caninus-On an old stump by the pool, in the wood, at Llanforda (scarce).

Spheria concentrica-Upon an old ash tree at Maesbury.

" multiformis-On rails in Llanforda (first park), and at Craigforda.

, nummularia-Upon an ash tree near Penylan bridge.

" lata-On dry wood near Penylan mill.

, leiphomia-On dead oak branches, Oswestry.

" laburni-On laburnum, Oswestry.

, cupularis-On lime branches, Oswestry.

, elongata-On broom, Llanforda.

,y yuccœ-On yucca glancescens, Oswestry.

, sanguinea-On timber, at Llanforda.

" moriformis-On an old tree under the Blodwel rocks.

", pulvis-pyrius-Llanforda.

, eutypa-On a dead tree near Llwynymaen.

Phacidium patella-About Oswestry.

Scleroderma vulgare-Woods at Llanforda and Porkington.

Lycogala epidendrum-Llanforda.

Reticularia umbrina-On a decayed larch pole, Oswestry.

Trichia fallax-Llanforda.

, clavata-Llanforda.

", turbinata-Llanforda.

Trichoderma viride-On fallen trees, Oswestry. 


\section{GEOLOGY.}

Tubercularia granulata-On lime branches, Oswestry.

Torula antennata-On fallen timber, Llanforda.

Puccinia saxifragarum-On adoxa moschatellina; lanes about Oswestry.

Fecidium viole-Mynydd-y-myfyr.

Uredo scillarum -Llanforda.

\section{Geologr, \&t.}

The town of Oswestry is situated upon and near the southern termination of the North Wales Coal Field, which extends a little farther south of the town, and, north-west, through Ruabon, Brymbo, Flint, Mostyn, and on to the sea, near the Great Ormshead. Running parrellel, and lying at the back, or to the west of these coal-measures, is the great belt of mountain limestone, commencing at Llanymynech Hill, and extending also, north-westerly, to the Ormshead, and from thence dipping into the sea.

The metalliferous character of the district is distinguished for the production of lead, copper, and zinc. Trials have been made for minerals at Treflach Wood, and portions of carbonate and sulphuret of copper, of average qualities, have been found, but not in sufficient quantities to justify extended operations. At Llanymynech Hill both copper and lead, sulphurets and carbonates, with carbonate of zinc, or calamine, have been raised in Iarge quantities by various companies, and occasionally the ores have reached a high per centage, ranging from five to twenty-five per cent. The ores are found in beds or flats, at from thirty to fifty yards from the surface, and lying between, and running parallel with, the strata of limestone that inclose them. It is an extraordinary fact, that the metalliferous belt of limestone abruptly terminates at the south end of the hill, and cannot be traced farther. Proceeding west, at the back of Oswestry, in Treflach Wood, there are some fine beds of Derbyshire marble or entrochal limestone, that have been worked for mantle-pieces and other ornamental purposes. 


\section{GEOLOGY.}

Trials have been made, and small quantities of lead and copper found in this limestone belt, extending to Minera, including the Eglwyseg range which bounds a portion of the Vale of Llangollen, near to Ruabon.

The Minera district is too well known for its rich mineral products, especially of lead and zinc, to require particular notice, and the same may be said of the Mold, Halkin, and Holywell mineral formation, passing on with continued fine mineral deposits, to Talargoch, near Prestatyn, in Flintshire.

The coal-measures in the district of Oswestry abound in fossils, Lepidodendrons, Sigillaria, Stigmaria, and Calamites, $\& c$. ; and the carboniferous limestone is much more prolific of that class of fossiliferous productions which usually accompany the old mountain limestone.

The application of capital and scientific labour to mining operations, during the last ten years, has given to the district an active and business-like character, and brought with it a large increase to the working population. At Llanymynech Hill, in addition to mining operations, there are annually raised about 60,000 tons of limestone, which is chiefly used for farming purposes in Montgomeryshire and Shropshire. At Porth-y-Waen rocks, in the same range, there is nearly the same quantity of limestone raised. The united quantities hewn and blasted from these vast limestone rocks produce about 70,000 tons of burnt lime, thus showing the extended use now made of limestone in the cultivation of farm lands in the immediate district.

The manufacture of iron is most extensively carried on in Ruabon parish, principally by the New British Iron Company, the quantity of good bar iron made amounting on the average to 350 tons per week. These works give employment to about 2,500 people, men and boys. The Company works its own collieries, and consumes nearly all the coal its 


\section{BIOGRAPHY.}

numerous pits produce. In the same parish there are two extensive manufactories, for the conversion of the ores of calamine and black jack (carbonate of zinc) into zinc or spelter, and at each of these places from twenty to thirty tons of these metals are made.

The coals raised from the coal-fields in and around Oswestry, worked by Messrs. Croxon and others, amount to about 40,000 tons per annum; whilst nearly 250,000 tons are raised in the Ruabon district, and a much larger quantity at Brymbo.

At Minera a powerful Company is actively engaged in working the old mines that produced so much ore during the former operations upon them. These mines were closed from the influx of water, and the inadequacy of the machinery then employed to carry it off. The present Company have, with an enterprising spirit, adopted the highest class of machinery, and employed the best mining talent that could be procured. By these means, which have called forth the application of at least $£ 50,000$ to this gigantic undertaking, the Company has fortunately succeeded in discovering rich veins of lead-ore, which produce from 100 to 150 tons per month. Other mining companies are also largely engaged in the district, some of which are producing large quantities of lead-ore.

\section{Biouraptyon.}

Oswestri, although not the birth-place of many distinguished men, has amongst its present population some " choice spirits," men born not, perhaps, to wield " the fierce democracy," or to attract the nation's glare by the display of brilliant talents, yet who possess the happy art of imparting sterling benefits to their fellow-men, and scattering blessings all around them. We could point to gentlemen, still honourably connected with the borough, whose good names must be well-deserved, because they have been earned among their 


\section{BIOGRAPHY.}

fellow-citizens. The borough has nevertheless extended education to several eminent characters, and been the chosen residence of many others. The names of Kenyon, Charles W. W. Wynn, West, Parker, Longueville, Lloyd, Donne, and Dovaston, are still cherished with grateful recollections, their talents and labours having been ably exercised for the social benefit and intellectual advancement of the town.

We subjoin a few sketches of worthies that did the "State some service," and whose connection with Oswestry claims for them a notice in these pages:-

Dr. Thomas Bray, an eminently pious and learned divine of the 17th century, was educated in Oswestry. He was afterwards entered of Hart Hall, Oxford, took his degree of Master of Arts there, was chosen by Dr. Compton, Bishop of London, to model the infant church at Maryland, and afterwards took the degree of Doctor in Divinity. He returned from Maryland, after a long and useful residence there, and rendered immense service to the cause of foreign missions, by his numerous publications and remarkable personal exertions. He closed a useful life in 1730, having reached the age of seventy-three years. He was born at Marton, in Salop:

John Freeman Milward Dovaston, M.A.-The death of this sweet poet, accomplished musician, and profound naturalist, occurred in August, 1854. Mr. Dovaston was not a native of Oswestry, but his birth-place (Westfelton) being so near to the borough, and his social connexion with it so constant and intimate during the whole of his life; that he may fairly be ranked among the celebrities of the town. $\mathrm{He}$ was the only son of John Dovaston, Esq., of "The Nursery," at Westfelton, a man also of great natural talents, and who was distinguished for his science, learning and ingenuity. The subject of our present notice was educated for the Bar, 


\section{BIOGRAPHY.}

but having a dislike for the profession, and possessing an ample property left by his father, he preferred a life of literary leisure, amid the charming scenery in his neighbourhood, to the wordy war and the feverish excitement of forensic ambition. In his sylvan retreat he sought amusement and instruction from the glories of nature so profusely scattered around him, and with the pure taste of the poet and philosopher, found

\section{"Sermons in stones, \\ Tongues in trees, books in running brooks, And good in every thing."}

In early life he published a volume entitled "Fitz-Gwarine and other poems," to which he made considerable additions in later years, He also published an able discourse on Natural History, and contributed two lectures on Music and National Melody. He was the author of a most interesting sketch of Bewick, the clever wood-engraver, whom Mr. Dovaston styled "the celebrated xyographer and illustrator of nature;" wrote several prologues and epilogues to histrionic performances for charitable purposes; and employed his graceful pen so long as Providence gave him mental and bodily strength. For several years, however, he was confined to his bed, and died at the age of 72 years. His education was commenced at Oswestry Free Grammar School, to which Institution he reverts, in the pride of his manhood and the fervent inspiration of the poet; and subsequently he was removed to Shrewsbury School, where he remained for some years, under the able tuition of Dr. Butler, afterwards Bishop of Lichfield. Mr. Dovaston's poetic genius led him almost entirely into the realms of nature. His ardent fancy revelled amid flowers and trees, murmuring rivulets and mountain torrents, or roamed among "boxen bowers" and greenwood shades, where no sounds are heard but the drowsy hum of bees, the joyous notes of the mavis or the lark, or the plaintive warblings of his "bonny robin." His metrical romance of "Fitz- 


\section{BIOGRAPHY.}

Gwarine" gives evidence of high descriptive power; and his Ballad, entitled "Bala Water," will bear comparison with the best stanzas of Scott. His works will live in the district in which they were written, comprising as they do so many local allusions; but had his muse soared to loftier themes, he would, in all probability, have transmitted to posterity a name which the lovers of song throughout the land would have delighted to honour. Never having been married, he left a considerable property, which is now in the possession of his relation, John Dovaston, Esq.

Guto (x GLYN,) or Griffith, of Glyn, having been elected a burgess of Oswestry, is enfitled from that distinction, as well as from his genius as a poet, to a brief notice. We have already quoted from his quaint description of Oswestry, but we shall now give it entire, as it was this production of his muse that procured for him the honour of enrolment as a burgess of the town. He was a native of Llangollen, and domestic bard to the Abbot of Llanegwestl, or Valle Crucis, near that town, to whom several of his poems are addressed. $\mathrm{He}$ is represented as witty and social, and was an acceptable guest at the halls of the Welsh nobility and gentry in his triennial visitations through the Principality. His gentle muse must have been more than ordinarily gracious when he poured forth such mellifluous strains as the following, in honour of Oswestry :-

"Oswestry is the liberal, the best endowed of cities;

The beloved of heaven that draws me to it.

Oswestry the strong fort of conquerors; the London of Powys;

Where the houses are well stored with wine, and the land is rich.

Its school is celebrated, and its city for preachers and men of science.

- GoD is present in its beautiful temple-

A church adorned with rich chalices,

And with bells and a rich-toned organ.

No better choir is there from it to Canterbury:

None in which there is correcter singing,

Or the habilments more suitable.

To White Minster I know no convent superior. 226 


\section{BIOGRAPHY.}

The handsomest and best-dressed women are those of Oswestry.

It resembles Cheapside in merchandize,

And its people are honest and unanimous.

GoD's grace be with the city, and those that dwell therein;

May GoD be its guardian and kind preserver."

Humphrey Humphreys, D.D., an eminent prelate, born November 24th, 1648, was for some years placed at the Free School of Oswestry, under the care of his uncle, Humphrey Wynn, A.M., who was master of the school and vicar of the parish. Bishop Humphreys was an able Welsh antiquary, and wrote some memoirs of eminent Welshmen, in addition to those contained in Wood's Athence Oxonienses, printed in the last edition of that work, and in the first volume of the Cambrian Register. "He was a person of excellent virtues during the whole course of his life, and in his latter years of a piety so extraordinary, as has but few examples."

Thomas Jones, son of John Williams, was born in Oswestry, and distinguished himself as an able defender of the Protestant faith. Having received his early education in his native town, he was entered at Jesus College, Oxford, at the commencement of the rebellion, but he left the University soon after, and returned when Oxford was surrendered to the Parliament, in 1646. He became Fellow of University College, by authority, of the parliamentary visitors, in 1648 , and was remarkably zealous in the republican cause. He took the degree of M.A. in the year following, and in 1655 became rector of Castell Caerinion, in Montgomeryshire, where he acquired a knowledge of the Welsh language, to serve those parts where the orthodox clergy were rejected. His subsequent life was marked by strong zeal against papacy, and in an action for slander brought against him by Dr. Morley, Bishop of Winchester, whom he charged as a promoter of popery, he was fined $£ 300$, and the rectory of Llandyrnog, to which he had been appointed, was sequestered for the payment of it. He continued this severe course of 227 


\section{BIOGRAPHY.}

polemic warfare, and published several other works, amongst which, in 1682, "Elymas the Sorcerer; or a memorial towards the discovery of the bottom of this Popish Plot." This effusion exposed him to much persecution, and would have subjected him to further punishment, had he not escaped by his decease, which occurred at Totteridge, Herts, in the same year.

Humphrey Krnaston, surnamed The Wild.-This remarkable man, whose exploits would furnish skilful romancewriters with materials for at least three entertaining volumes, was not a native of Oswestry, but as there is a tradition that his first wife was Elizabeth, daughter of Meredydd ab Hywel ab Morris, of Oswestry, and another that she was Margaret, daughter of William Griffith, of Oswestry, called CochWilliam, or the Red, we have deemed his history worthy of brief narration in this volume. Kynaston was son of Sir Roger Kynaston, of Hordley, by Elizabeth, daughter of Henry Grey, Earl of Tankerville, by Antigony, daughter of Humphrey, Duke of Gloucester. The enormous debts he contracted by his imprudent life and conduct caused him to be outlawed, upon which he fled from Middle Castle, his usual place of residence, but which he had so neglected that it was falling into ruins, and sheltered himself in a cave in the western point of Nesscliff Rock, called to this day Kynaston's Cave. The cave is large, and divided into two rooms by a pillar of the rock, upon which is carved " $\mathrm{H}$. $\mathrm{K}$. 1564." Yorke says of him, that "he was a gentleman of many strange pranks, still the talk of the neighbouring peasantry. The cave in the rock, at Nesscliff, called Kynaston's Cave, was the retreat of himself and mad companions. He was outlawed the sixth of Henry VII., pardoned the next year, and died in 1531." Kynaston's career was brief, but his exploits and vagaries within the short period of twelve months filled the country round with enthusiastic reports of his courage and semi-madness. His horse, somewhat re228 


\section{BIOGRAPHY.}

sembling the notorious Turpin's "Black Bess," seemed to have an instinctive knowledge of his master's love of daring adventure. Tradition states that this animal was stalled in the cave, the ascent to which was by a flight of steps, and that when he was grazing in any of the fields below, on hearing his master's whistle, he would immediately attend to the summons, ascend the steps of the cave, and kneel at Humphrey's bidding. Kynaston is represented as no common outlaw, and that in all his depredatory warfare he ever regarded a sort of justice, giving freely to the poor, by whom he was idolized, a portion of the "black mail" he had levied from the rich. On the road, if he saw a cart with one horse, and another with three, he made them equal, by taking the fore-horse from the latter and hooking it to the former. Most of the adventures ascribed to him seem to have been more dictated by whim than a desire of plunder. He had a plentiful supply of necessaries from the people around, the rich paying him tribute through fear, and the poor from gratitude. Kynaston's Horse-leap, a place thus named on Dovaston Common, received its name from the following circumstance: Kynaston having been observed to go over Montford Bridge to Shrewsbury, the Sheriff, intending to take him, caused one of the divisions of the bridge (then formed of planks laid upon stone pillars,) to be taken up, and placed a number of men in ambush. When Kynaston had advanced on the bridge, the men came up and blocked up his retreat, upon which he put spurs to his horse, which bore him safely over the wide breach, and carried him to his cave at Nesscliff; some say the horse leaped into the Severn, and carried him across! The length of this leap was afterwards measured on Dovaston Common, with an $\mathbf{H}$ cut at one end and a $\mathbf{K}$ at the other. The letters were an ell long, a spade's graffe wide, and a spade deep, and were generally cleansed annually by order of Mr. Kynaston, of Kington, as Gough, the historian of Middle, informs us. Camden merely mentions Nesscliff and its cave, but says not a word about Kynaston. Wild 


\section{BIOGRAPHY.}

Humphrey's adventures were probably much exaggerated by the vulgar people of the district, some of whom have not scrupled to declare that his leap was forty yards! Kynaston, being a desperate man, would not hesitate much at daring feats, but a forty yards' leap is fit only for record in the pages of Major Longbow.

Edward Llwyd, or Lloxd, the celebrated antiquary, although not a native of Oswestry, was closely connected with it, as he was the natural son of Edward Lloyd, of Llanforda, a man of dissolute character, and who, after dissipating his estate, died without legitimate issue. Edward Llwyd was born in 1660, and at the age of seventeen was entered in Jesus College, Oxford. He studied fossils, and became under-keeper of the Ashmolean Museum, and in 1680 succeeded to the head-keeper's place, vacant by the resignation of his friend and patron, Dr. Plot. In 1704 he took the degree of M.A. His researches into the languages, histories, and customs of the original inhabitants of Great Britain obtained for him a distinguished name; but the chief fruit of his studies and travels was his "Archceologice Britannica," of which Baxter, in a letter to Sir Hans Sloane, said, "That it was the work of an age, rather than of a few years; that it gave great light to the history and antiquities of Britain, and was an honour to his ancient country." $\mathrm{He}$ was elected Fellow of the Royal Society, and in the following year the University gave "proof of the high esteem in which it held his extensive learning, by electing him Esquire Beadle in Divinity ;" but he did not long enjoy the appointment, as he died after a few days' illness, in June 1709. His manuscript collections, relating to Welsh and Irish antiquities, consisted of above forty volumes in folio, ten in quarto, and upwards of one hundred of smaller sizes. They were ultimately sold to Sir Thomas Seabright, of Beachwood, Herts, and were afterwards purchased from Sir John Seabright, part by the late Thomas Johnes, Esq., of Hafod, and the other 


\section{BIOGRAPHY:}

part by the late Sir W. W. Wynn, Bart., of Wynnstay. Some years afterwards, Mr. Johnes' portion of these literary treasures were consumed in a destructive fire that broke out at his elegant mansion, and a similar fate befel the more valuable of the Wynnstay portion, they having been consumed in a fire which occurred on the premises of a bookbinder in Covent-garden, London; where they had been sent for the purpose of being bound.

William Maurice, of Cefr-Y-Braich, and Hugh Morus; the Bard of Ceiriog.- These two able men, although not Oswestrians, were so closely connected with the town, as natives of the neighbouring parish of Llansilin, that a few words on their biography will not be misplaced. Mr. Maurice was an eminent antiquary, and the industrious collector of the library of manuscripts now in the Wynnstay library. He was descended from Lowri, sister of Owen Glyndwr, and what is singularly coincident, he married Letitia,.. a descendant of Glyndwr's successful opponent, Henry Bolingbroke. She was a Kynaston, ' of Morton, descended from the Greys of Powys, and the Greys from Antigony, daughter of Humphrey, Duke of Gloucester, fourth son of Henry IV:- William Maurice was so devoted to Welsh literature, that he erected close to his house, at Cefn-y-Braich, a building three stories in height, for his library. It was called "The Study," but has long since been in ruins. Mr. Walter Davies says of it, "From what I recollect of it, and of a print in an old Oxford almanack of 'Friar Bacon's Study,' in that university, I judge the one to have been a fac simile of the other." This assiduous antiquary died from about 1680 to 1690 .

Hugh Morus, the Poet, as he is emphatically called, because he excelled all others in the smooth and flowing awen, or song-writing, was born at Pont-y-Meibion, in the Vale of Ceiriog, in the year 1622. He died in 1709 , at the advanced 


\section{BIOGRAPHY.}

age of 87 years, as appears from his tomb-stone in Llansilin church-yard having lived in six reigns, exclusive of the commonwealth. His songs, carols, \&c., hundreds in number, show his fertile genius, and many of his productions are marked by wit, irony, fun, satire, and high poetic beauty. He was a frequent visitor at Porkington and Chirk Castle, and always a welcome guest.

Mr. John RExnolds.-This gentleman, a native of Oswestry, was a nephew of Mr. John Davies, of Rhiwlas, Denbighshire, author of a small work entitled "Heraldry Displayed." After his uncle's death he published a Book of Pedigrees, from Mr. Davies's manuscript, in the quarto form.

The Rev. Peter Roberts, A. M., an able writer on Welsh history, resided in Oswestry for some time. He was born at

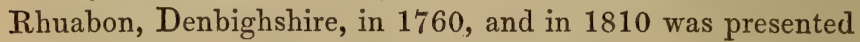
to the living of Llanarmon Dyffryn Ceiriog. He was prevented by the delicate state of his health from residing on his living for more than a few of the summer months, his regular home being in the town of Oswestry, where he was generally respected for his literary talents and private worth. In 1814 the freedom of the borough was presented in full assembly to Mr. Roberts, as "Author of numerous and extensive publications," "for his deep and laborious researches of ancient records," and "in consideration of his profound learning." Astronomy and the Oriental languages were his favourite studies in the early part of his life, and he had aspired to the Astronomical Chair in Trinity College, Dublin, as successor to the celebrated Archbishop Usher, whose friendship and regard he had long possessed. The illustration of his native language, and of the ancient history of the Cymry, afterwards deeply engaged his attention, and to the discussion of these subjects he brought such powers of mind, united with such multifarious learning, that he reminded his contemporaries of the gigantic power of the renowned Edward Llwyd, and 232 


\section{BIOGRAPHY.}

justly entitled himself to the high eulogium of Bishop Horsley, who declared "there was only one Peter Roberts in the world." He closed his earthly career at Halkin, Flintshire, in 1821, whilst administering relief to a poor parishioner; he was seized with apoplexy, and died in a few hours afterwards. His published works were numerous and able. In the list we find "Christianity vindicated, in a series of letters to Mr. Volney;" "Harmony of the Epistles;" "an essay on the Origin of the Constellations;" "Art of Universal Correspondence;" A Sketch of the Early History of the Cymry or Ancient Britons;" "Review of the Policy and Peculiar Doctrines of the Church of Rome;" "Manual of Prophecy;" "Collectanea Cambrica;" "Letter to Dr. Milner, on the supposed miracle at St. Winifred's Well ;" "Cambrian Popular Antiquities," \&c.

"Dick Sрот."-A man figuring under this patronymic, but whose real name was Edward Morris, flourished at Oswestry some years ago. He was celebrated as a conjuror or professor of legerdemain, and pursued his tricks with such marvellous success that the name of "Dick Spot" was popular among the humbler classes throughout the district. He professed to tell a love-sick damsel who was to be her husband; to detect thieves by turning a key upon the Bible; and by other "craft and subtlety" inspired his credulous visitors with hopes of coming grandeur and overflowing fortunes, \&c. At length death arrested Morris in his deceptive career, and his remains were consigned to the earth in Oswestry Church-yard. Hulbert, in a notice of Oswestry, in his "History of the County," refers to Dick Spot's career, and says, "On requesting an eccentric but ingenious inhabitant, now one of the Churchwardens, to furnish me with some particulars of a pamphlet said to be the Life of Dick Spot, he thus replied,-'I know not who has got his life, but this I know, that I am in possession of his mortal remains in 


\section{BIOGRAPHY:}

Oswestry Church-yard, having purchased the spot of earth which contained them, from his grand-daughter. His skull, which I had in my hand the other day, was treated with very. little respect by the Hamlet-like grave digger.' If poor Morris had been blessed with the gift of foresight, he certainly would have directed that his mortal remains should be deposited in a more secure place of sepulture." "Who the eccentric Churchwarden was the historian does not inform us. We are half inclined to believe that his grave discovery was a hoax, a species of pleasantry, somewhat resembling what is called "Bolton Trotting," and which two or three well-known wags were wont to indulge in, many years ago, occasionally. with thoughtless imprudence and merciless severity. .

Mr. Robert Salter.-This gentleman's family had for centuries been connected with Oswestry, the name of "Salter" being recorded in civic documents of very ancient date. $\mathrm{He}$ was author of a piscatorial work, entitled "The Modern Angler," a brochure, written in a series of letters to a disciple of Isaac Walton, and evidencing a thoroughly-practical acquaintance with the art of angling. It was published in 1811. Like that celebrated lover of the finny tribes, he looks upon his favourite recreation with the warmest enthusiasm of his craft, and quotes Walton's refreshing picture of some of the angler's joys on closing a long day's sport. Safely landed at some "friendly cottage, where the landlady is good, and the daughter innocent and beautiful: where the room is cleanly, with lavender in the sheets, and twenty ballads stuck about the wall; : there he can enjoy the company of a talkative brother sportsman, have his trouts dressed for his supper, tell tales, sing old tunes, or make a catch. There he can talk of the wonders of nature, with learned admiration, or find some harmless sport to content him, and pass away a little time, without offence to God, or injury to man.". Mr. Salter's Letters are worthy of re-publication.

234 . 


\section{放ntulutiliti.}

The use of coaches was introduced into England by FitzAlan, Earl of Arundel, in the year 1580. At first they were drawn only by two horses, but about the year 1619 six horses were used by the notorious Duke of Buckingham.

The Duke of Powis visited Oswestry in the Mayoralty of Robert Barkley, Esq. (1737), in whose accounts are the following items :- “Aug. 8th-Paid Mrs. Sarah Evans' bill for wine, for his grace the Duke of Powis, at the Town Hall, 13s. 3d.; paid John James, for drink to a bonfire when his grace the Duke of Powis was at the Town Hall, 2s. 6d!"

Oswestry Association, for the prosecution of felons, formed Dec. 14th, 1771. by John Lloyd, Esq., Solicitor. First Treasurer, Mr. Edward Browne. Mr. Lloyd was the original institutor of societies for the prosecution of felons.

Races re-commenced September 1802, under the patronage of Sir W. W. Wynn, Bart., after being discontinued 17 years.

The foundation of Castle Buildings was laid February 1803.

The first Sheriff's Court held at Oswestry, on Friday, June 20 th, 1804.

Stage-coach first established from Shrewsbury, through Oswestry to Holyhead, by Mr. Robert Lawrence, of Shrewsbury.

The Holyhead and London mail-coach first ran through Oswestry, instead of Chester, 6th September, 1808, when great rejoicings took place; a saving of 22 miles was effected in the journey by this change.

Act of Parliament passed in 1809, for paving, cleansing, lighting, watching, and otherwise improving the streets, and other public passages and places within the borough. 


\section{NOTABILIA.}

In 1809 Charles Williams Wynn, Esq., Recorder of Oswestry, received the thanks of the Corporation and inhabitants of the borough, for voting independently in the case of the late Duke of York, and for his strict attention to his

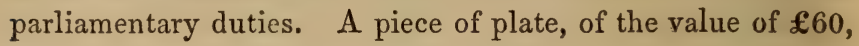
was presented to him at the same time.

From 1811 to 1814 about three hundred French prisoners of war (military and naval) on parol in Oswestry. They were in the service of Napoleon Bonaparte, and consisted of French, Germans, Spaniards, Dutchmen, Poles, \&c. Among them were the Prince D'Aremberg, General Phillipon (who broke his parol), and other officers of distinction.

In 1812 a Grand Musical Festival was held in the Parish Church, on occasion of the opening of the New Organ. The Messiah was performed with great eclât in the church, and a Miscellaneous Concert was given in the Theatre.

In 1814 the freedom of the borough was presented in full corporative assembly to John Freeman Milward Dovaston, Esq., A.M., of West Felton, author of Fitz-Gwarine, and other beautiful poems, "as a mark of their respect and admiration of his very pleasing poetic talents, and taste for elegant literature."

The New Gaol finished in 1816.

Monday, January 6th, 1817, The Archduke Nicholas, of Russia (the late Emperor), passed through Oswestry from Wynnstay, on his way to Powis Castle.

William Ormsby Gore, Esq., High Sheriff of the County in 1817.

The New Burial Ground (formerly Vicar's Croft), consecrated by the Bishop of St. Asaph (Dr. Luxmoore), October, 1817. 
Oswestry Herald Newspaper first published by the author of this book, March 21st, 1820, and discontinued Tuesday, Dec. 31st, 1822. In those days the newspaper stamp-duty was $4 d$., and advertisement-duty $3 \mathrm{~s}$. $6 \mathrm{~d}$. on each advertisement. The newspaper was swamped by excessive taxation.

February 14th, 1820, the Mayor and Corporation of the borough proclaimed the accession of George IV. to the throne.

The celebrated Mile Oak Tree felled Monday, May 20th, 1824. The girth of the lower part of the tree, $16 \frac{1}{2}$ feet; the largest branch, 5 feet 10 inches in circumference; length of the tree, 57 feet.

Evening Lectures commenced June 20th, 1824, in Oswestry Church, by the Rev: Thomas Salwey, Vicar of the Parish.

The Church and Burial-ground at Trefonen consecrated by the Bishop of St. Asaph, on Wednesday, January 17 th, 1825, and service commenced on Sunday morning, January 24th, by the Rev. John Hughes.

The Chancel and new entrance-door to the Parish Church, from Church-street, finished in 1831.

Our present Gracious Sovereign, when Princess Victoria, on her way from Powis Castle, visited Oswestry, with her illustrious mother, the Duchess of Kent,in September, 1832. The royal visitors were received at Croes-wylan gate by the High Steward (the Hon. Thos. Kenyon), the Deputy-Mayor, the Coroner, and other members of the Corporation, in their robes, and a large number of the gentry and tradesmen of the town bearing white wands. The Princess and her mother did not alight from their carriage, but merely changed horses at the Wynnstay Arms. During this short stay Mr. Kenyon congratulated the royal visitors in the name of the Corporation, and was commanded by the Duchess of Kent to inform the 


\section{NOTABILIA.}

"good people of Oswestry" of the "very great satisfaction she felt at the manner in which she was received by the inhabitants of the town and neighbourhood, and that she felt obliged by their loyal and affectionate feeling manifested towards herself and the Princess Victoria." The Corporation and gentlemen conducted the cavalcade to the Beatrice Gate, and the Oswestry squadron of North Shropshire Cavalry, under the command of Captain Croxon, escorted the royal party to Chirk Bridge. Here they were met by Sir W. W. Wynn, Bart., and a detachment of the Denbighshire Cavalry. Captain Croxon having been introduced to the Princess and Duchess, and received their thanks, the royal party proceeded onward to Wynnstay.

A new Church Clock put up, by subscription, April, 1836.

The first Writ of Enquiry from the Court of Queen's Bench, Pierce v. Foulkes, was tried at Oswestry, December 5 th, 1837.

A Vestry held 15th July, 1842, to assess a church-rate. Objections raised against the Organist's salary, which, upon vote, was rejected by a majority of five. The following Sunday the organ was not played, nor was there any singing!

November 2nd, 1842, Prince Ferdinand of Austria passed through Oswestry.

In 1846 the Corporation of Oswestry, assisted by the inhabitants of the borough, and the gentry of the neighbourhood, entered into a subscription to present to the Recorder (J. R. Kenyon, Esq.,) a piece of plate, on his marriage, as a testimonial of their regard and esteem. The plate consisted of a salver of chaste and elegant workmanship, weighing upwards of $164 \mathrm{oz}$, and measuring across twenty-four inches. The inscription in the centre was as follows:-(Surmounted by the Arms of Oswestry). "To John Robert Kenyon, D.C.L., 


\section{NOTABILIA.}

on his marriage, from the Corporation and inhabitants of the town of Oswestry, in testimony of the deep respect in which he is held as Recorder of the borough, and the grateful feelings entertained for his liberal support of the different charitable institutions connected with the town."-(The Family Arms below.)

Oswestry is 450 feet above the level of the sea, and 254 feet higher than the Shrewsbury meadows. Shrewsbury is 196 feet above the level of the:sea.

The following heights of places above the sea, either near or in sight of the Great Western Railway (Birmingham, Shrewsbury, and Chester Sections, ) taken by the Rev. T. E. Evans, of Trinity College, Cambridge, are "facts worth knowing :"-Hawkstone, 834 feet; Grinshill, 696 ; Nessc'iff, 630 ; Llanymynech church, 246; Breiddin, 1,236; Wrekin, 1,494; Cyrn Moelfre, 1,746; Cader Ferwyn, 2,826; Cern:y-Bwch, 1,206. By Mr. Murchison:-Oswestry, 460; plan of Shrewsbury, 97; surface of the Ellesmere canal under Heathhouse bridge, 260 feet. The canal at Chirk is the height of two locks more than the canal near Whittington. Allowing 24 feet for the rise, it would make the surface of the canal at Chirk, -334 feet.

The late Rev. Walter Davies, rector of Manafon, in his Historical notice of Llansilin, published in the first volume of the Cambro-Briton, says, "In 1699 there was a well in the parish of Oswestry, called Ffynnon Maen Tysilio, where the inhabitants resorted to celebrate their annual Wake.

Oswestry Show, long since discontinued, was generally held on the first Thursday after Trinity Sunday. As a pageant it bore no comparison with Shrewsbury Show. The incorporated companies of the town walked in procession, preceded with flags, bands of music, \&c. 


\section{NOTABILIA.}

"There was formerly," says the Oswestry Herald, "a castle at Maesbury, in that township, as we find from Domesday Book. Rainald the Sheriff (all whose estates devolved on the Fitz-Alans,) held Maesburie under Roger et ibi fecit Rainaldus Castellum Lvvre." No mention of this castle is made by Pennant, Bingley, or any subsequent historian or tourist.

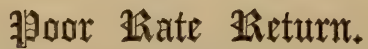 \\ OSWESTRY TOWN AND PARISH (1855.)}

\begin{tabular}{|c|c|c|c|}
\hline Town and Parish. & Acreage. & Gross Rental & 1. $\begin{array}{c}\text { Rateable value } \\
\text { assessed to } \\
\text { the Relief of } \\
\text { poor. }\end{array}$ \\
\hline Oswestry Town \& Liberties. & $\begin{array}{crr}\text { A. } & \text { R. } & \text { P. } \\
1753 & 2 & 24\end{array}$ & $\mid \begin{array}{ccc}\mathscr{L} & \text { s. } & \text { D. } \\
16604 & 18 & 6\end{array}$ & \begin{tabular}{c|ccc} 
& E & S. & D. \\
6 & 14933 & 13 & 0
\end{tabular} \\
\hline Parish & $13911 \quad 1 \quad 31$ & $22280 \quad 0 \quad 0$ & $02 \begin{array}{llll}20052 & 10 & 3\end{array}$ \\
\hline
\end{tabular}




\section{SKETCHES}

OF

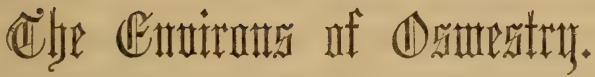

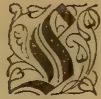

UFFICIENT has been said in these pages to justify much more extended notices than we can give to the ancient castles, fine old mansions, and modern residences of wealthy proprietors in this neighbourhood, imparting as they do so much additional beauty and interest to the bold and picturesque natural scenery in the midst of which they are so tastefully situated. Oswestry, as we have already described, is not only a pretty town, but historically curious; anc the charms of nature and art surrounding it render it still wore worthy of admiration. We append brief descriptions of neighbouring places, all fixed near the Border Lands of England and Wales, whose history teems with glowing narratives of embattled hosts, of fierce chieftains in bright array, and of minstrels famed

\section{"In Cambria's noon of story,}

Ere bright she set in glory!"

Almost every nook and corner has its historic tale, its love or war-song, or its tradition. These remains of ancient times and deeds of bravery, with natural beauties superadded,mountains, valleys, and rivers, of surpassing loveliness, have 


\section{ASTON HALL.}

invested the Environs of Oswestry with an enduring interest with which few, if any other towns in the kingdom, can vie. Our District Sketches, being arranged alphabetically, will commence with

\section{ASTON HALL,}

The seat of Mrs. Lloyd, widow of the late William Lloyd, Esq. It is situated on the right of the turnpike-road from Oswestry to Shrewsbury, about two miles distant from the former. The highly-respected family who have for so many years occupied this beautiful estate are of great antiquity, having descended from Einion, Prince of part of Powys, who distinguished himself in the wars against Henry I. Yorke, in his "Royal Tribes of Wales," writing in 1799, has furnished a copious notice of the house of Aston. "The Lloyds," he says, "are descended from Einion. The heiress of the house, Elizabeth, daughter of Thomas Lloyd, married Foulke Lloyd, of Fox Hall, or the hall of Foulke, and was great grandmother to the Rev. John Robert Lloyd, Rector of Whittington and Selattyn, both in his advowson, the present possessor of Aston. The name of the Fox Hall family was Rosindale, when they came first from the north. To a younger branch, settled at Denbigh, we owe our learned countryman, Humphrey Llwyd. He was of Brazen-nose, Oxford, studied physic, and lived as family physician in the house of the last Earl of Arundel, of the name of Fitz-Alan, the Chancellor of the University. He sat in Parliament for his native town of Denbigh, and died there in the forty-first year of his age, and was buried in the Parish Church with a coarse monument, a dry epitaph, and a psalm-tune under it. He collected many curious books for Lord Lumley (whose sister he married), which form at this time a valuable part of the Library in the British Museum. One of his sons was settled at Cheam, in Surrey, whose great grandson, Robert Lloyd, was Rector of St. Paul's, Covent Garden, and contended, but without effect, for the Barony of Lumley." 


\section{CHIRK CASTLE.}

Trevor, of Brynkinalt, Speaker of the House of Commons in England, and first Lord Commissioner of the Great Seal, assumed the name and arms of Trevor, and was created, April 27th, 1765, Viscount Dungannon." An interesting fact connected with this noble family is, that the mother of the Duke of Wellington, the "Hero of a hundred fights," was Anne, Countess of Mornington, daughter of Arthur Hill, the first Viscount Dungannon. This illustrious lady was closely allied with two greatly-distinguished men: her husband, the Earl of Mornington, ranked high as a musical composer, and "s the Duke," her son, placed himself high on the roll of fame with conquerors of ancient and modern renown.

The present Viscount Dungannon takes much interest in archæological pursuits, and is author of an ably-written work, in two volumes, 8vo., entitled "The Life and Times of William the Third, King of England, and Stadtholder of Holland." His Lordship has acquired the literary distinctions of M.A., F.A.S., and M. R.S. L., and is an active magistrate for the district in which he resides. He has large possessions in the north of Ireland, in which he takes much interest.

\section{CHIRK CASTLE,}

The noble residence of Colonel Myddelton Biddulph, is situated near to Chirk, on elevated ground on the Berwyn range of hills, commanding delightful views of the surrounding scenery. It is a bold castellated mansion, built of grey stone, partly mantled with ivy, and is supposed to have been erected on the site of an ancient fortress called by the Welsh Castell Crogen, near which, as is recorded, the celebrated Battle of Crogen took place in 1164, when the Welsh fought with more than their usual bravery against Henry II., for the recovery of their independence. The present castle was built in the reign of Edward I. by Roger Mortimer, son of Roger, Baron of Wigmore, to whom the king had granted the united lordship of Chirk and Nanheudwy. 


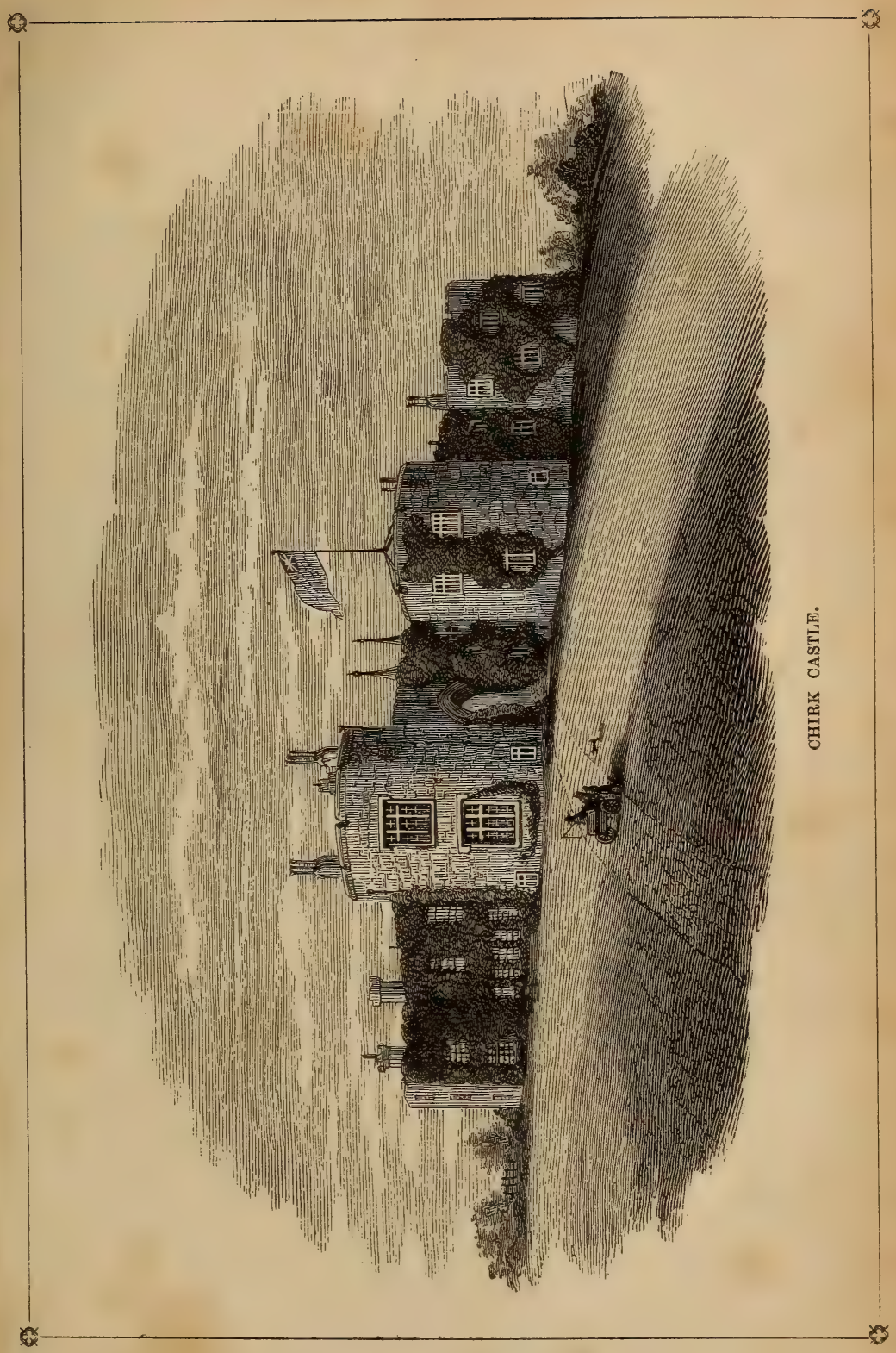





\section{CHIRK CASTLE.}

'The Castle continued in the hands of the Mortimer family but a short period, it being sold by John, grandson of Roger Mortimer, to Richard Fitz-Alan, Earl of Arundel, whose family possessed it for three generations. It afterwards passed to Thomas Mowbray, Duke of Norfolk and Justice of North Wales, Chester, and Flint, in right of his wife, Elizabeth, eldest sister to Thomas, Earl of Arundel. It then devolved upon the Beauchamp and Neville families, and afterwards became the property of Sir William Stanley, together with Holt Castle. Henry VIII. bestowed it upon his natural son, Henry Fitzroy, Duke of Richmond and Somerset; in the following reign it was granted to Thomas, Lord Seymour, brother to the Protector Somerset. Queen Elizabeth granted it to her favourite Dudley, Earl of Leicester, and on his death it became the property of Lord St. John, of Bletso, whose son, in 1595, sold it to Sir Thomas Myddelton, Knight, Lord Mayor of London, in a branch of whose family it still remains.

It is stated that the erection of the Castle was begun in 1011, and finished in 1013. The building partakes both of the castle and mansion, the form quadrangular, the angles being strengthened with bastion-like towers, each surmounted by a small turret. The principal entrance, through a fifth massive arched tower, is at the north front, leading into a court-yard 160 feet long by 100 broad. Around this are ranged the different apartments, and the east side is ornamented by a handsome colonnaded piazza. The north and east wings are occupied by the family, and the south and west given up to the offices. The most remarkable of the apartments are, a saloon of sixty feet by thirty, lighted by three large mullioned windows looking towards the court; a drawing-room thirty feet square; and an oak gallery, extending the whole length of the west wing, one hundred feet by twenty-two, leading to the chapel. The ceilings throughout are ornamented by rich plaster work, and the rooms display a large collection of paintings. Among 245 


\section{CHIRK CASTLE.}

the portraits are those of the Myddelton family, Sir Orlando Bridgeman, the Duke of Ormond, and his son Lord Ossory, the Countess of Warwick, daughter of the fourth Sir Thomas Myddelton, and afterwards wife to the celebrated Addison, author of the "Spectator" and other classic writings. Among the landscapes there is a view of the admired water-fall, Pistill Rhaiadr, in Montgomeryshire, represented as falling into the sea. Of this work of art a pleasant story is told. The artist employed in taking the view was a foreigner, to whom it was hinted, when he had nearly finished the picture, that the addition of a few sheep would add to the effect. The painter replied, "you want some sheeps in it. O! O ! ver veil. I vill put you some sheeps in it." He then introduced the sea, and with it several ships! The picture being thus Iudicrously transformed, it was allowed to remain in its altered state as an artistic curiosity ; and the visitor when inspecting it is sure to have his risible muscles disturbed by so droll a metamorphosis. The gallery contains several old cabinets, the work probably of Italian or French Artists; one, an exceedingly handsome one, a gift from Charles II. to the brave Sir Thomas Myddelton.

The history of the Myddelton family is one of national interest. There were four Sir Thomas Myddeltons at Chirk Castle, the two former knights, and the two latter baronets. The first Sir Thomas was Lord Mayor of London when his brother, the celebrated Hugh Myddelton, was knighted for bringing the new river into the Metropolis. The second Sir Thomas served in Parliament for the county of Denbigh, and took arms in its support when he was fifty-seven years old. For his services at Oswestry, Montgomery, and Holt, in 1643-4, he received the thanks of Parliament through the Speaker. When he engaged in the service of the Parliament his own castle became garrisoned forthe king, and the veteran knight was compelled to besiege it with all his force. It remained, however, in the hands of the royalists till February 246 
1646, when Sir John Watts, the governor, quitted it, and was captured, with his men, at Churchstoke, Montgomeryshire. Sir Thomas Myddelton, some ten years afterwards, abandoned the parliamentary cause, and took up arms with Sir George Booth, a Cheshire general, to restore the monarchy, and place Charles II. on the throne. The royalists were few in number, and easily defeated, by Lambert, who retook Chester, and made Sir George Booth prisoner. He then laid siege to Chirk Castle, which, after a sharp resistance, was surrendered by Sir Thomas Myddelton, who deemed it useless, he said, to oppose the whole kingdom. A resolution was passed in parliament, authorizing Lambert to demolish the Castle; but, Cromwell dying the same year, the threatened destruction did not take place. The damage and loss sustained at Chirk Castle, during the usurpation, are said to have amounted to $£ 130,000$. Such was the reward which the veteran Sir Thomas Myddelton received for his patriotism. His fate resembled that of his co-patriot, Major-General Mytton, but was somewhat more disastrous.

Sir Thomas's son, of the same name, was made a baronet at the Restoration. The son died in 1663, his father surviving him three years, when he died at the age of 80 years. His grandson, the fourth Sir Thomas, and the second baronet, married twice. By his second wife, Charlotte, daughter of the Lord-Keeper Bridgeman, he had an only daughter, Charlotte, who married first to the Earl of Warwick, and secondly to Addison, as already mentioned. Their daughter, Miss Addison, died unmarried. The baronetage became extinct at the death of Sir William, son of Sir Richard, brother to the last Sir Thomas, Sir William having died unmarried in 1718. The estate, by the entailment, came to Robert Myddelton, eldest son of Richard, the third son of Sir Thomas, the soldier. He, dying without issue, was succeeded by his brother John, father of Richard, father of Richard Myddelton, Esq., for many years M.P. for the Denbigh boroughs, who died 


\section{CHIRK CASTLE.}

unmarried in 1796. The estate was afterwards divided among his three sisters. The eldest, Mrs. Myddelton Biddulph, had for her share Chirk Castle and its domain, and it is now in the possession, as before stated, of her son, Col. Myddelton Biddulph. The second sister, Maria, who married the Hon. Frederick West, brother of the late Earl of Delawarr, had for her portion the property in Llangollen, Rhuabon, Wrexham, and Holt. The third sister had for her portion Ruthin Castle with its demesnes, and died unmarried; her property, with that of the Hon. F. West, came into possession of his son, Frederick Richard West, Esq., M.P. for the Denbigh Boroughs, who now resides at Ruthin Castle, a portion of which has been re-built, and the whole greatly embellished under his tasteful superintendence.

Chirk Castle is among the most interesting and oldest-inhabited feudal buildings in the kingdom. Its

"Towers, unmodernized by tasteless art, remain

Still unsubdued by time.",

The family have hitherto protected it from injury, as it has been repaired with care and skill where much decay or damage had presented itself, but in no degree to impair its original character. Within the last few years considerable improvements and alterations have been made in it, under the direction and superintendence of the late Mr. Pugin. The lower apartments are of the pure gothic of the fifteenth century. The large rooms are in the style of Francois the First. The bed in which Charles I. slept when he visited Chirk Castle, in his "utmost need," in 1646, is still shown in a room adjoining the gallery. The south-west wing has undergone little if any alteration by modern art, and there may still be traced the architecture of the period in which the fortress was erected.

The large estate surrounding the Castle has been much improved by Col. Myddelton Biddulph; the grounds and 248 



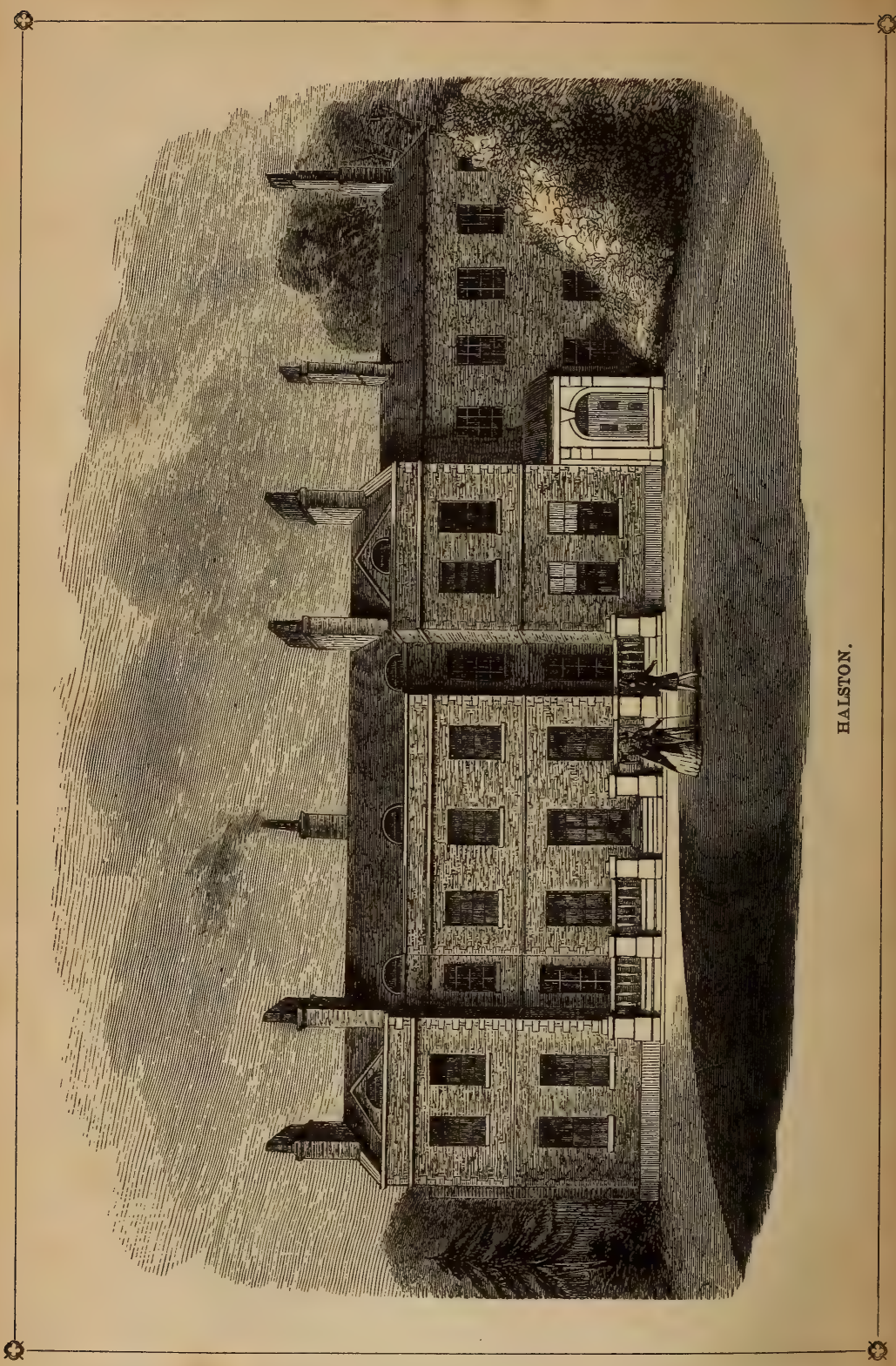




\section{HALSTON.}

noble trees that ornament it are kept in excellent order, and the farms upon the property are all in a flourishing and healthy condition.

Col. Myddelton Biddulph is Lord Lieutenant of the county of Denbigh, and representative also for the shire.

\section{HALS'TON,}

The seat of Edmund Wright, Esq., was for several centuries the property of the Myttons. It is situated within a mile of Whittington, on the Oswestry and Ellesmere turnpike road. It is called in ancient deeds Haly-stone or Holy-stone. Near the house stood the abbey, taken down about a century and a half ago. The Rev. Peter Roberts says, "That it had. been a sanctuary is evident. Meyric Lloyd, lord of some part of Uwch Ales, in the reign of Richard I., would not yield subjection to the English Government, under which the Hundred of Dyffryn Clwyd and several others were then, and having taken some English officers that came there to execute the law, (which was contrary to the customs of the Britons,) hanged some and killed others. For this act he forfeited his lands to the king, fled, and took sanctuary at Halston, where (for his notable enterprises and merited chivalry,) he was taken under the protection of its possessor, John Fitz-Alan, Earl of Arundel, 'who made him general of the army in the besieging of Acon, in Asia, anno dom. 1190, where he behaved himself,' as Reynolds informs us, 'with such dexterous attempts as were admirable to the spectators." " [See his exploits further recorded in our notice of "Llanforda."]

In the Saxon era the Lordship of Halston belonged to Edric, at which time there were on the property two Welshmen and one Frenchman. After the Conquest Halston became the property of an Earl of Arundel, or of Robert, Earl of Shrewsbury, and was afterwards bestowed on the Knights of St. John of Jerusalem. In the 26th Henry VIII. the commandry was valued at $£ 16014$ s. 10 d. a year. On 


\section{HALSTON.}

the abolition of many of the military-religious orders and monasteries, Henry empowered John Sewster, Esq., Scutifer, and afterwards allowed him to dispose of this manor to Alan Horde, who made an exchange with, or sold it to Edward Mytton, Esq., of Habberly, ancestor to the present John Mytton, Esq. This alienation was subsequently confirmed by Queen Elizabeth.

In a manuscript account of Halston, written in 1821 by the late Rev. C. A. A. Lloyd, we find the following description :"The Manor of Halston is extra-parochial. The Mansionhouse of Halston was formerly situated near the chapel, but in the year 1690 it was removed to its present situation, which is on an elevated spot of ground rising out of an extensive flat, and formerly subject to frequent floods. The grandfather of the present owner (the late John Mytton, Esq.,) was a gentleman of great spirit and enterprise, and at considerable trouble and expense drained vast tracts of the low ground, which rendered the neighbourhood more healthy. The river Perry here forms several islands, and its shores are shaded by oaks, perhaps the finest in the country." After describing the pictures and books at Halston at the time he was writing, he adds, "Mr. W. Mytton was engaged for many years in collecting materials for a History of the County, but unfortunately died before he arranged them. Among the collection is a manuscript copy of the History of the County, by Mr. E. Lloyd, of Trenewydd, which Mr. Pennant, by some blunder, mistook for Mr. Mytton's."

The Chapel of Halston is a donative, without any other revenue than what the chaplain is allowed by the owner, and is of exempt jurisdiction.

The Mytton family are of great antiquity, and their connection with Shrewsbury is of remote date. The late John Mytton, Esq., sold, among other property belonging to him in that town, a field called the "Chapel Yard," on Coton 


\section{HALSTON.}

Hill. When Leland visited Shrewsbury the Myttons lived on Coton Hill. In the bailiff's accounts for a year from Michaelmas, 2nd Richard III., among rents in decasu (in decay) is one "Procapella de Coton Thome Mytton," the sum defaced; and his descendant Thomas Mytton, Esq., was rated for it to the poor as late as 1686. Major-Greneral Thomas Mytton, the great parliamentary commander in the Civil Wars, was a descendant of the Myttons of Shrewsbury. Halston was his birth-place, and he resided there for many years. He was a zealous and untiring leader of the parliament forces under the Commonwealth, and gave his days and nights to the Protector's cause; but he lived long enough to realize the truth of the poet's exclamation,

"How wretched is the man that hangs on Princes' favours!"

He saw men of inferior talent, but ostentatious in profession, placed over him in rank, and had to suffer the penalty which many others paid for their attachment to Cromwell-the neglect and indifference of the party whom he had so long delighted to serve, and the favour of the Protector extended to sycophants and flatterers.

The late John Mytton, Esq., was the last member but one of the family who possessed the Halston estates. This unfortunate gentleman passed a brief life in folly and dissipation, and closed his existence with an unenviable notoriety. On reaching his majority he found himself the owner of immense wealth, in money and landed property. Under pernicious influences he plunged into extravagance, recklessly squandered away his patrimony, and in a few years became the inmate of a gaol,

"Deserted at his utmost need, By those his former bounty fed."

He drew his last breath within the gloomy walls of a prison, at the early age of thirty-eight, and was interred, with his ancestors, in the burial-ground at Halston Chapel. 


\section{HALSTON.}

It is painful to advert to so lamentable a career and so distressing an end. But, whilst we point to Mr. Mytton's ruinous habits, we cannot withhold the acknowledgment that he had redeeming qualities. Like most men of his pursuits, he often found the means he possessed too limited for his own wants; yet occasionally he would perform noble and generous deeds, that might be classed with the purest benevolence. His mental calibre was of no common order. Had he been rightly disciplined in his youth, and trained to habits of selfdenial and literary improvement, his life might have been honourable, and extended to a good old age. "It was the misfortune of John Mytton," as a county historian observes, "to lose his father in his infancy, and it is remarkable that the heirs of the house of Halston have for several generations been orphans."

Mr. Mytton was High Sheriff of Salop in 1823, and represented Shrewsbury in the last parliament of George III., being elected May 23rd, 1819. He was a candidate the second time for the same borough, in March, 1820, the other candidates being Panton Corbet, Esq., and the Hon. Henry Grey Bennett, but was then defeated. His Parliamentary career was therefore but of short duration; but brief and useless as it was, it cost him many thousand pounds, to raise which a large portion of his Shrewsbury and other property had to be sold.

Mr. Mytton married in 1818, soon after he became of age, a daughter of Sir Thomas Jones, and sister of the late Sir Thomas John Tyrwhitt Jones, of Stanley Hall, near Bridgenorth, by whom he had one daughter only, who is now the wife of Captain Clement Hill, a brother of Lord Hill. Mrs. Mytton died in 1820, and in the following year he married Caroline, one of the daughters of 'Thomas Giffard, Esq., of Chillington, in the county of Stafford, by whom he had an eldest son John, (who sold the Halston estate to Mr. Wright,) and several other children. Mrs. Mytton survived her 


\section{KNOCKIN.}

husband, but at her death, although from Mr. Mytton's erratic habits she had been compelled to separate herself from him, she was, at her own request, laid in the grave at Halston by his side.

The Halston Estate was purchased in April 1847 by the late Edmund Wright, Esq., of Manchester, from the present Mr. Mytton. The property was offered for sale by auction on the 13 th of that month, at Dee's Royal Hotel, Birmingham. At Mr. Wright's death it came into the possession of his son, Edmund Wright, Esq., the present worthy owner. Since his possession of the estate he has greatly improved it. Additions have been made to the house, and he has otherwise rendered. it more convenient and ornamental. The park has been thoroughly drained, four feet in depth, within the last three or four years, the main drain being carried underneath the upper pool, by which means an ample fall for the efficient working of the drain is secured.

\section{KNOCKIN.}

We briefly notice this place, from its antiquity, and having possessed a castle, erected in the reign of Henry II. Knockin is in the hundred of Oswestry, as already stated; is a rectory discharged, in the diocese of St. Asaph, and the deanery of Marchia. It is situated five and a half miles south-east of Oswestry. The origin of the name is not known. There is no mention of it in Domesday Book, nor in any of the British Chronicles before the Conquest. Camden refers to it but with brevity. The castle was built by Lord L'Estrange, the first of whose family was Guy L'Estrange (Guido Extraneous,) a younger son of the Duke of Bretagne. He had three sons, Guy, Hamon, and John, all of whom held lands in Shropshire by gift from Henry II. The younger Guy was Sheriff of Salop from the sixth to the eleventh of Henry II. ; and again from the seventeenth to the twenty-first of Henry II., Ralph, his son, gave (the first of Richard II.) the chapel of Knockin 


\section{LLANYMYNECH.}

to the canons of Haughmond. He left no issue, and his three sisters became his co-heiresses. John, grandson of Guy, in the thirty-third of Henry IlI., procured a market for the town on a Tuesday, and a fair on the eve-day and day after the anniversary of the decollation of St John the Baptist. Madog, who was at the head of an insurrection against the king's officers in North Wales, marched against the Lord Strange, and defeated him at Knockin. The male line of the family failed in John Le Strange, who died in the seventeenth of Edward IV., leaving an only daughter, Joan, who married George, son and heir of Thomas Stanley, who was created Earl of Derby by Henry VII. The castle was first demolished in the civil wars in the reign of King John, and repaired by John Le Strange in the third of Henry III. The title of Knockin is still kept up, though the family is extinct, the eldest son in the Derby family being styled Lord Strange. The castle was long since a heap of ruins, and scarcely a vestige of it remains to be seen. The materials of which it was composed were worked up to build the church-walls, \&c.; and, " tell it not in Gath, publish it not in the streets of Askelon!" cart-loads of the stones were carried away to repair the roads! The Poor-rate return for the parish gives the following statements :-Acreage, 1,384; gross rental, $£ 2,131$; rateable value assessed to the relief of the poor, $£ 1,916$.

\section{LLANYMYNECH}

Is situated about six miles from Oswestry, on the turnpikeroad leading from thence to Welshpool. The parish contains one township, Carreg Hofa (Offa's stone,) which, although detached from, yet is within the county of Denbigh, but attached to Montgomeryshire for election and other purposes. The other two townships, Llwyntidman and Treprenal, are within the county of Salop, but on the borders of Montgomeryshire. The church is dedicated to St. Agatha. Patron, - the Bishop of St. Asaph. The present Rector is the Rev. John Luxmoore. In the chancel is a monument to the memory of 


\section{LLANYMYNECH.}

the wife and daughter of George Griffith, Bishop of St. Asaph, who had been Rector of this parish whilst Canon of that Chapter. He was of the House of Penrhyn, in Caernarvonshire, and was consecrated to the above See in October 1660, in reward for his piety and great sufferings in the royal cause. A tablet, in another part of the church, has the following singular inscription:- "Randolph Worthington, died in the West Indies, of the yellow fever, nobly fighting for his king and country." The church and village are beautifully situated

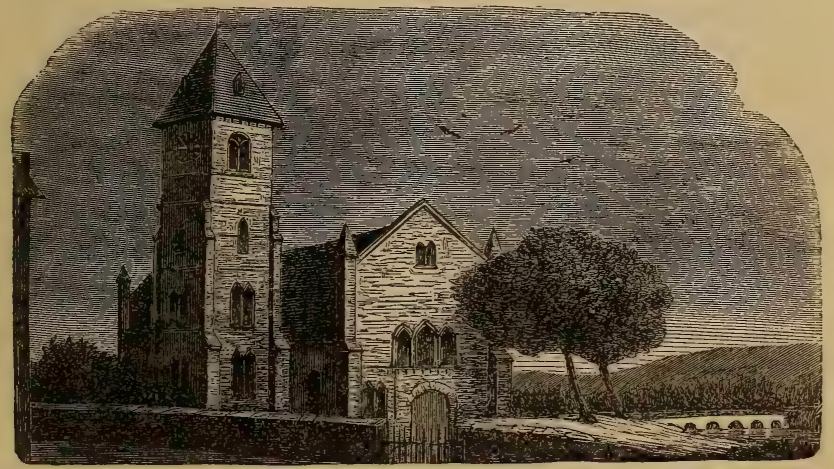

LLANYMYNECH CHURCH.

on a gentle slope above the river Vyrnwy, and from Llanymynech Hill present the appearance of a charming Swiss scene. Various interpretations of the name of the village are given. Some etymological writers have said that the word Llanymynech means "the Village of the Miners," whilst others contend that it signifies "the Church of the Monks, or Monkstown." Since the invasion of the Romans the hill has been known as mineral ground, so that the origin of the name "Village of the Miners," is easily understood. A monastery is said to have been in existence here at an early date, and hence "the Church of the Monks," \&c.

An ancient mansion called Carreg Hofa Castle once stood in the parish, but was demolished about the beginning 


\section{LLANYMYNECH.}

of the 13th century. Having been built of wood, not a vestige of the Castle remains. A foss, to guard the most inaccessible approach on the east, is the only index left. It was taken and pillaged in 1162, by the two cousins Owen Cyveiliog and Owen ab Madog. The latter kept possession of it for twenty-five years, and was eventually slain in it by Gwenwynwyn and Cadwallon, sons of Owen Cyveiliog.

Offa's Dyke separates the parish into two nearly equal parts, and continues its course as described in page 10. The river Morda divides the parish on the east from Kinnerley, and on the north it joins the parish of Oswestry.

Llanymynech Hill is an extensive tract of land, on the limestone formation, comprising about 160 acres. It belongs to F. R. West, Esq., M.P., and the minerals upon it are leased to the "Carreg Hova Copper and Lead Mining Company." The limestone rocks, part of which are 900 feet in height, are worked by another Company, and large quantities of fine limestone are annually raised and sold, principally for agricultural purposes, in Shropshire and Montgomeryshire. The ores raised from the hill are carbonates, sulphurets, and oxides of copper, carbonate of lead, and calamine (carbonate of zinc). On the north-west side of the hill are the remains of ancient surface mines, supposed to have been of Roman origin, and from vitrifications near this spot, there is no doubt that the Roman miners smelted their copper there in jars on open hearths. Near these old workings is an immense cave or level, known in the district by the name of the Ogo, from the Welsh Ogof-(a cave). Its windings are so numerous and intricate, that many years back the labourers, attempting to explore its mazes, were bewildered in the effort, and a number of miners, who had been sent in search of them, discovered them lying prostrate on the ground, in despair of ever again seeing the light of day. Skeletons, various utensils, and coins of Constantine and Vespasian, Antoninus and Faustina, have been found within and about the $O g o$. One of these skeletons 256 


\section{LLANYMYNECH.}

had a battle-axe by its side, and a bracelet of glass beads, like the druidical rings or beads called glain neidr, (the ova anguinum of Pliny,) and another with a golden bracelet encircling the wrist. In 1849 two other skeletons were found buried in trenches near the $O g o$, by the side of one of which lay a strong battle-axe, formed of mixed metal, but sharp at the edge. These skeletons were of a very large size, the bones evidently being those of remarkably tall men. The late Mr. J. F. M. Dovaston explored the Ogo several years ago, and declared that none of the paths extend more than two hundred yards from the entrance. Great quantities of human bones were found in many parts, especially where the cavern becomes wide and lofty, and this fact induced the belief that the place, at some early period, was a refuge in battle or a depository for the dead. For years it was commonly believed in the district that this labyrinth communicated by subterraneous paths with Carreg-Hofa Castle; and some persons have exercised their imagination so largely as to declare that, while in the far recesses of the cave, they have heard the rivers Vyrnwy and Tanat rolling over their heads, and that the said labyrinth actually leads down to fairy-land!

On the eastern brow of the hill there formerly stood a Cromlech, measuring seven feet by six, and eighteen inches thick. It was called by the Welsh people "Bedd-y-Cawr," or the Giant's Grave; and under it, according to tradition, a giant's wife was buried, with a golden torques about her neck. To search for this treasure three brothers named Paine, who lived in the neighbourhood some years ago, threw down the stone from its pedestal.

The prospect from Llanymynech Hill is indisputably one of the finest in the kingdom. On the Welsh side are seen the summits of mountains, rising in every variety of ridge, the distant in the softest azure, and the nearer in the most brilliant verdure, with hanging woods, fertile meadows, and the brightlyshining rivers, Vyrnwy and Tanat, uniting in the valley below, and sweeping their sunny waters to join the Severn, under the 257 


\section{LLANYMYNECH,}

abrupt and bold rocks of the Breiddin range of mountains. At a considerable distance, when enlightened by the sun, may be seen the glistening water-fall of Pistill Rhaiadr. Turning towards England the expansive Vale of Shropshire is seen richly wooded, and profuse in luxurious vegetation, terminated by the column and spires of Shrewsbury, the Wrekin, and the far distant hills of Staffordshire and Cheshire. In a northerly direction the Shropshire Union Canal is seen glitteringly interlacing the rich meadow land; the graceful lake at Llynclis peeps out amidst over-shading trees; and the ancient tower of Oswestry parish church completes the diversified and enchanting series of landscapes. We lately lieard a visitor from Switzerland, just arrived at Llanymynech Hill from that far-famed picturesque country, declare that he had seen nothing in the land of William Tell to compare with the beauty and grandeur of the scene before him. Enraptured with the prospects, he enthusiastically exclaimed, as the celebrated Lord Lyttleton had done on viewing Festiniog Vale, "With the woman one loves, with the friend of one's heart, and a good library of books, one might pass an age here, and think it a day !"

To the south-west lies Carreg Hofa Hall, formerly the pleasant retreat of Sir Thomas Jones, Chief Justice of the Common Pleas, and representative for Shrewsbury in 1660 . It came into the possession of Sir J. T. Tyrwhitt Jones, Bart., Usher of the Black Rod, and father of the first wife of the late John Mytton, Esq., of Halston. Further in the same direction is Pentre Heilyn, the seat of the Heilyn family, some members of which occupy a distinguished place in Cambrian biography. Below the western brow of the hill is Aber Tanat, formerly the seat of the Tanats, or Tanads, descended from Einion, who took their name from the river Tanat, near their house, for the same reason as the Mostyns, the Glynnes, \&c., to avoid the redundancy of Aps. Blodwel, a little farther north, was the graceful theme of bards and minstrels when Welsh song and music went joyously hand 258 


\section{LLANYMYNECH.}

in hand. Llwyn-y-groes, formerly the seat of the late John Evans, M.D., (but now of Richard Nightingale Broughton, Esq.,) viewed also from the hill, claims special notice. Dr. Evans was popular in the literary world, and his didactic poem, "The Bee," enriched with instructive notes, philosophical and botanical, is still read with delight. Dr. Evans was father of the author of " The Rectory of Valehead," a work which obtained public favour, and still holds its place as a literary production of high merit. The late $\mathbf{M r}$. Robert Baugh, of Llanymynech, was another distinguished parishioner. He officiated for many years as clerk of the parish, but his talents as a land surveyor and draughtsman procured for him a high reputation. His large map of Shropshire, a work honourable to his talents, is still referred to for its accuracy.

The identification of the Roman encampment at Clawdd Coch, in the parish of Llanymynech, with the ancient Mediolanum, is still a disputable point. A learned antiquary, the Rev. R. W. Evans, Vicar of Heversham (son of the late Dr. Evans), considers that such identification is clearly established; and the late Rev. Peter Roberts, who had viewed the place, "would fain insist, in conversation, that it was the identical spot where Mediolanum once quartered the legions of ambitious Rome." The late Rev. Walter Davies, no mean authority on questions of antiquity, paid much attention to the subject, and after personal inspection of Clawdd Coch, came to the conclusion that Mediolanum is still among the terre incognita.

The following is the estimated extent, gross rental, and

\begin{tabular}{|c|c|c|c|c|c|c|c|c|}
\hline rateable va & th & $\begin{array}{r}\text { Est } \\
\text { ex }\end{array}$ & $\begin{array}{l}\text { mated } \\
\text { tent. }\end{array}$ & Gross & rental. & $\begin{array}{c}\text { Rate } \\
\text { val }\end{array}$ & $\begin{array}{l}\text { able } \\
\text { ue. }\end{array}$ & \\
\hline Town & & & R. $\mathrm{x}$ & P. $\mathscr{f}$ & s. D. & . & s. & D. \\
\hline Llwyntidr & & 1052 & 32 & 292227 & $4 \quad 10$ & $0 \mid 2227$ & & 10 \\
\hline & & 227 & 21 & \begin{tabular}{l|l}
16 & 309
\end{tabular} & 160 & \begin{tabular}{l|l|}
0 & 309
\end{tabular} & 16 & \\
\hline Carreghofa, & $\begin{array}{l}\text { County of Denbigh, } \\
\text { now annexed } \\
\text { to Montgomery. }\end{array}$ & 1221 & & 224 & & 61968 & & 6 \\
\hline & To & 2502 & 12 & $\overline { 2 3 } \longdiv { 4 7 6 1 }$ & 16 & 44505 & & 4 \\
\hline
\end{tabular}




\section{LLANFORDA,}

The residence of the Right Hon. Sir Henry Watkin Williams Wynn, K.C.B. and G.C.H., is situated one mile and a half west of Oswestry. The original estate was part of the possession of Einion Evell, Lord of Cynllaeth and Mochnant, from whom it descended, together with Llwyn-y-Maen, to Ievan Vychan, constable of Knockin, whose heiress, Agnes, carried it into the family of the Lloyds, by her marriage with Maurice Lloyd, of whom the Welsh records give the following account:- "The said Maurice Lloyd ab Bleddyn Lloyd, finding himself much oppressed by the English Laws, did kill one of the judges and hanged divers other officers on oak trees in Uch-dûlas, upon whose conviction his lands and inheritance in Denbigh-land were escheated to the Crown, and so still remains for most part to this day, and known by the name of the said Maurice Lloyd ; and he for his safeguard withdrew himself to the sanctuary of Halston, in the county of Salop, and there betook himself to the protection of John Fitz-Alan, Lord of Oswestry and Clunne, and after Earl of Arundel. By the said Earl's commission he levied a great number of soldiers out of the said Earl's Lordships and Hundreds in the marches of Wales, and made the said Maurice Lloyd Captain over them, and the said Earl of Arundel being then General of the English forces, the King of England sent them to assist the Emperor in the Holy Warre against the Turke, in which service, at the scaling of, and entering, the breach at the siege of Acon, the Emperor's colours were taken by the enemies, and recovered back by the said Maurice Lloyd, and brought again by him to the Emperor, in reward of whose valour and faithful service therein the Emperor gave him the coat of the house of Austria, only changing the field for his first coat in his achievements before the parental coat of Hedd Moelwynog." The bearing thus acquired, and constantly used by his descendants, was the imperial eagle in a field sable. From Maurice Lloyd the Llanforda property descended to Richard Lloyd, who, dying in 1508, divided the 


\section{LLANSILIN.}

estate, and left Llanforda to his eldest son John, and Llwyn. y-maen to his second son Edward. Llanforda eventually passed from the hands of this family, Edward Lloyd, a man of dissolute character, having sold it to the first Sir William Williams, Speaker of the House of Commons in the two last Parliaments of Charles II., about the year 1685, in whose posterity (the Wynnstay family) it has since continued. The Edward Lloyd just mentioned was father, as we have stated in our Biographical notices, of the celebrated scholar and antiquary, Edward Llwyd. There was formerly a church at Llanforda, but it was suppressed by Rynerus, Bishop of St. Asaph. The river Morda passes close to the estate.

Sir Henry Wynn is a Privy Councillor, and for twenty-five years filled the important office of Minister Plenipotentiary to the Court at Copenhagen. He is also a magistrate for the county of Salop.

\section{LLANSILIN}

Is situated in the county of Denbigh, but the parish being on the confines of Salop, and near to Oswestry, a brief notice here will not be inappropriate, The parish has numerous historical associations. It was the birthplace of Morris Kyffin, the learned translator into Welsh of Bishop Jewell's Apology; of Charles Edwards, the pious author of "Hanes-y-Fydd," a history of Christianity; of John Davies, author of "Heraldry Displayed;" and of Hugh Morris, the eminent Welsh poet and song-writer. Glasgoed, a seat of the Kyffins (the last heiress of which married Sir William Williams, Speaker of the House of Commons), is now the property of Sir W. W. Wynn, Bart.; and Plasnewydd, an ancient and pleasant residence, once the property of the Chirk Castle family, belongs to Thomas Hughes, Esq., who resides there. The late Rev. Walter Davies contends, in his historical notice of Llansilin, that Owen Glyndwr " was an inhabitant at least, if not a native of this parish." Pennant makes Sycharth, situated in the valley of the Dee, about three miles below Corwen, as the mansion of Owen, whilst Mr. Davies fixes the Sycharth, in the parish of 261 


\section{LLANYBLODWEL.}

Llansilin, as another of Owen's houses. He says, " in the year 1792 I had the curiosity to visit this spot (Sycharth) in Glyndyfrdwy, and also another place called, and universally known by the name of Sycharth, in this parish of Llansilin; and when I returned to Mr. Pennant's volume, I entered in the margin, opposite the name Sycharth,- 'Sycharth, the seat of Owain Glyndwr, described by Iolo Goch, in his Invitation Poem, is in the parish of Llansilin, about twelve miles to the south by east of Glyndyfrdwy." Mr. Davies adds, "As Owain was baron of two townships, no one will deny his having a seat in each; one on the Dee in Glyndyfrdwy, the other on the Cynllaeth, in this (Llansilin) parish."-In the church there is a fine monument of the first Sir William Williams, Speaker of the House of Commons.-The present Vicar is the Rev. Walter Jones.-The Poor-rate return for the present year (1855,) gives the acreage at 13,000 ; gross rental, $£ 11,88013 \mathrm{~s} .10 \mathrm{~d}$.; rateable value assessed to the relief of the poor, $£ 1,07016 \mathrm{~s}$. $2 \mathrm{~d}$.

\section{LLANYBLODWEL,}

Although now included in the county of Salop, is nevertheless on the borders of Montgomeryshire, and is in the diocese of St. Asaph. It is a rectory (cum cap. Morton), dedicated to St. Michael, and is valued in the King's books at £39 5s. Patron, the Bishop of St. Asaph. It is situated six miles from Oswestry, on the east side of the river, below Abercynllaeth, and above Aber-tanat. In Domesday Book it is called Bodowan-ham, and in an old deed of the Fitz-Alans Blodwel (dated in the time of Henry 6th,) Vawre Villata, which'means "the village of Great Blodwel." Welsh etymologists contend that the name of the place is derived from Blodau, a flower, the spring there being very early; whilst other writers say that the name originated in the Saxon "blood" and "wold," in consequence of the bloody and inhuman battle fought there between the Mercians and the Cymry (or Welsh). In this parish is Blodwel-Hall, the deserted seat of the Tanats, descended from Einion. The 262 



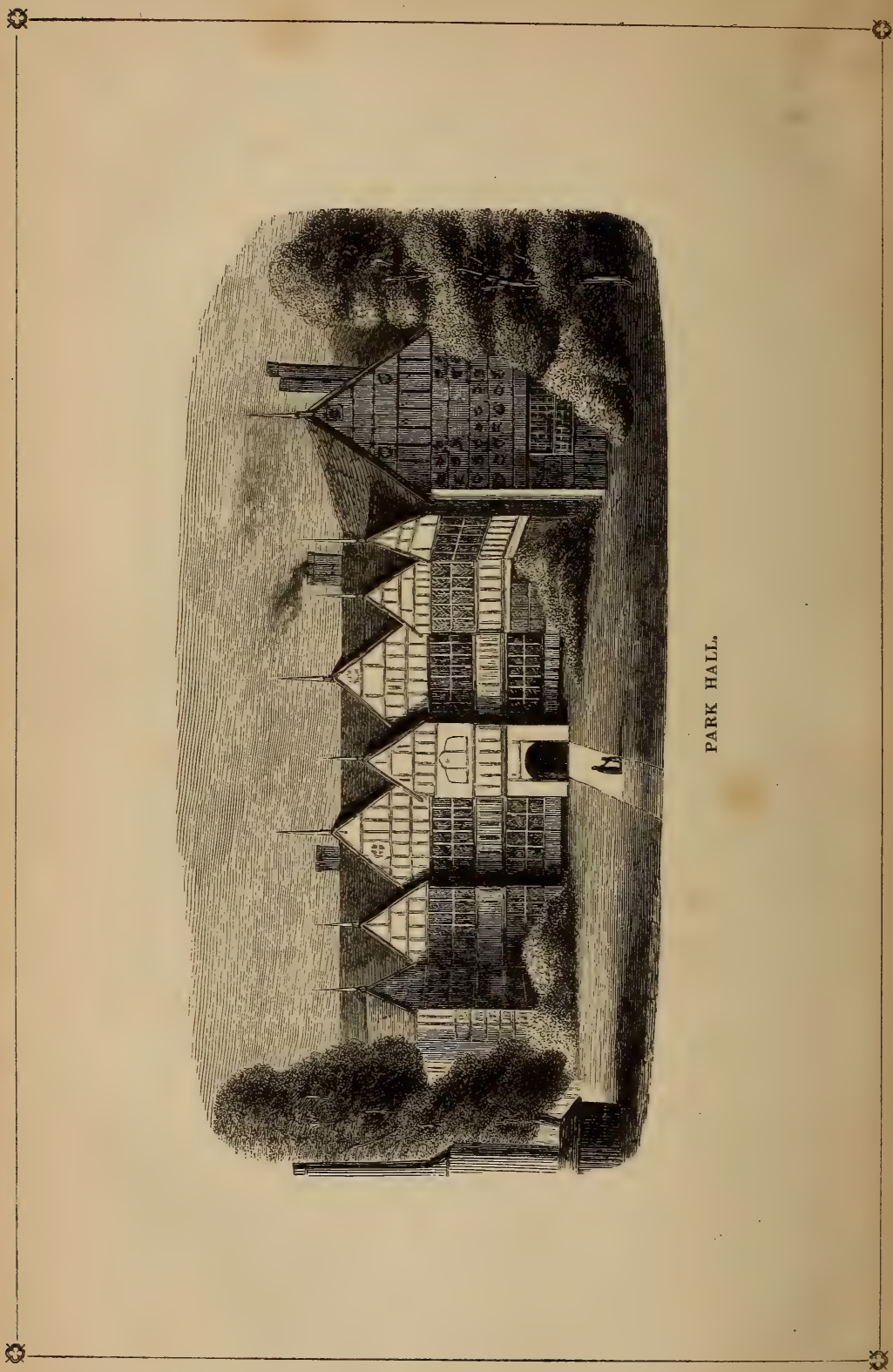


heiress of the house, Jane, married John Matthews, of Court, and the heiress of the Matthewses, Ursula, married Sir John Bridgman, grandson to the Lord-Keeper, Sir Orlando, and ancestor to the present Earl of Bradford, who inherits the estate. The rector of the parish is the Rev. John Parker, son of the late Thomas Netherton Parker, Esq., of Sweeney Hall, near Oswestry, and distinguished for his taste in eeelesiastical architecture and decorations.

\section{PARK HALL,}

In the parish of Whittington, the residence of Richard Henry Kinchant, Esq., is situated a little more than a mile east from Oswestry, and about the same distance from Whittington. It is one of those ancient timber mansions, few of which are now remaining in England, perhaps none in so perfect a state of preservation, and exhibits a fine specimen of the domestic architecture of bye-gone days. The estate on which it stands formed a portion, in ages past, of the once extensive and densely-wooded park appertaining to Whittington Castle, when that ancient stronghold could boast as its possessors in succession the powerful baronial families of Tudor Trevor, Peverel, Gwarine de Metz, and Fitz-Alan.

In those somewhat rare and beautifully-delineated maps of English counties, by Saxton, published in 1577, it is styled "The Park Hall." This very singular and time-honoured structure is presumed to have been built in the reign of Queen Mary (1553-8), by Robert ap Howell, otherwise Robert Powell, the first of that name seated at Park, son of Howel ap Griffith, of Oswestry, descended from a younger son of Ievan Vychan, of Abertanat, a junior branch of the royal line of Powys. It remained in this family until the death of Thomas Powell, High Sheriff in 1717; his line terminated in an heiress, Jane Powell, who sold the estate to Sir Francis Charlton, Bart., of Ludford, in the county of Hereford. Subsequently this property and that of Blundel Hall, near Bishop's Castle, became vested in the Kinchant family, by the marriage of John Quinchant (as the name was then spelt), of Stone 263 


\section{PARK HALL.}

House, near Ludlow, Shropshire, a Captain in the 32nd Regiment of Infantry, with Emma Charlton, daughter of the before-mentioned Sir Francis Charlton. By this marriage the present possessor of Park derives his pedigree from the Princes of Powys-land.

The house is $\mathbf{1 2 6}$ feet in length, the façade presenting numerous pointed gables, terminating in pinnacles. The entrance to the Hall is through a porch, and over the original oak door, which is of considerable thickness, and studded with large square-headed nails, is the following inscription, carved on stone, the letters in bold relief:- " Quod tibi fieri non vis alteri ne feceris." The chimnies, of solid brick-work, are quadrangular, a small space intervening between each, and crowned with a heavy mass of masonry uniting them together, and so placed as to present an angle to each of the cardinal points: thus formed they have resisted the tempests of three centuries. The hall is wainscoated, and is $33 \mathrm{ft}$. long by $23 \mathrm{ft}$. wide: it contains several old family portraits of the Charlton and Kinchant families. There is an oak table in it, cut from one plank, resting on massive turned pillars; the length is $23 \mathrm{ft}$. by $4 \mathrm{ft}$. in width, and $2 \frac{1}{2}$ inches thick: at one end is carved the date-1581. Over a door in the hall, leading to the great staircase, the arms of Powell, Needham, and Corbet, are painted in separate panels, of a deeply-recessed oak moulding. Thomas Powell, of Park Hall, who died in 1588, married Mary, daughter of Sir Robert Corbet, Knight, of Moreton Corbet, and his son, Robert Powell, married Anne, daughter of Robert Needham, Esq., of Shavington, sister of the first Viscount Kilmorrey. The large dining-room is beautifully wainscoated in diamond-shaped panels, and the mantel-piece is a noble specimen of rich oak carving. It bears the date 1640, with this motto carved on a scroll :"Nec vi nec vento." A Colonel Jones, of Shropshire, engaged with Cromwell's army, bore this motto on his banner, yet it does not appear that he ever resided at Park, or was connected 264 
with the Powell family. The ceiling is a fine example of plaster-work, and, as there appears no date upon it, is probably coeval with the house. It is ornamented with figures of birds, horses, and stags, and the central compartment has a representation in bold relief, of Neptune and his attendant Tritons. The great staircase, leading to the drawing-room, long gallery, and bedrooms, is a good specimen of the style of the 16th century; the balustrade of massive oak, the strong upright pillars, having pointed finials, are carved with a $\mathrm{T}$ like ornament, such as is of common occurrence on the ancient stone crosses of Wales. Underneath the window, on the first landing-place, is carved this sentence:- "Accurate cogita immutabilia." Here are also two fine paintings, the one by Holbein, representing the great reformers, Luther, Wyckliffe, Melancthon, and others, seated round a table; the other painting a boar hunt, after Schneider. The upper rooms are all wainscoated, and abound in elaborately-carved old oak furniture, some bearing dates early in the 17 th century. The gallery, extending nearly the entire length of the house, is hung with several old family portraits. There is a beautiful little chapel abutting on the west wing of the house; the windows are stained glass, the interior is wainscoated, and the whole arehed over with oak paneling; over the entrance is carved on stone these words :- "Petra et ostium Christus est." There is a gallery to the chapel, approached by a door from the drawing-room. On the south side of the garden is a terrace of considerable length, and in the centre stands a remarkable sun-dial, in stone, bearing several Latin inscriptions, alluding to the rapid flight of time: on the pediment is the date 1578. All the letters and figures on this stone, and all that are found in various parts round the house, are carved in relief. This dial fronts the south, and has no less than seven complete dials on it. On the terrace are likewise the fragments of several large stones and dials, bearing inscriptions in Latin. 


\section{PORKINGTON.}

In the List of the High Sheriffs of Shropshire will be found the following names, owners of Park Hall :-

\begin{tabular}{|c|c|c|c|c|c|c|c|c|}
\hline Robert Powell & - & - & & 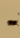 & - & - & - & 1647 \\
\hline Thomas Powell & $1-$ & - & - & - & - & $=$ & - & 1717 \\
\hline Job Charlton & - & - & - & - & - & - & - & 1748 \\
\hline John Charlton & Kinchant & - & - & - & - & - & - & 1775 \\
\hline Richard Henry & Kinchant & - & - & - & - & - & - & 1846 \\
\hline
\end{tabular}

\section{PORKINGTON,}

Situated about a mile from Oswestry, to the right of the road leading to the race-course, is the seat of William Ormsby Gore, Esquire, M.P. for North Shropshire. This delightful estate is associated with some of the most interesting incidents in the history of North Wales, and has for years been viewed as one of the great land-marks of the chequered history of the Welsh border. It derives its name from "Castell Brogyntyn," a fortress of the celebrated Owen Brogyntyn, a natural son of Madog ab Meredydd ab Bleddyn, Prince of half of Powys, and who, as a gift from his father, enjoyed the title of Lord of Edeirnion and Dinmael. He flourished in the latter part of the twelfth century. The site of the ancient fort still remains in the shrubberies of Porkington, the moat filled up serving as a gravel walk, surrounded by plantations. Owen resided at Brogyntyn, whence he assumed his surname. According to a drawing in the Mytton collection, the fort was of a circular form, surrounded by a large earthen dyke and a deep foss, that had two entrances close to each other, projecting a little from the sides, and diverging, the end of each being guarded by a semi-lunar curtain. The name of the fortress and house (for Owen Brogyntyn resided there) was soon altered into one closely resembling the present, as we find that in 1218 Henry III., in an address to Llywelyn, Prince of Wales, informs him that, among others, "Bleddyn Filius Oeni de Porkinton" had performed the service he owed to the English Crown. The house was formerly known also by the name of "Constables' Hall." The precise date of the change of name cannot be ascertained. 


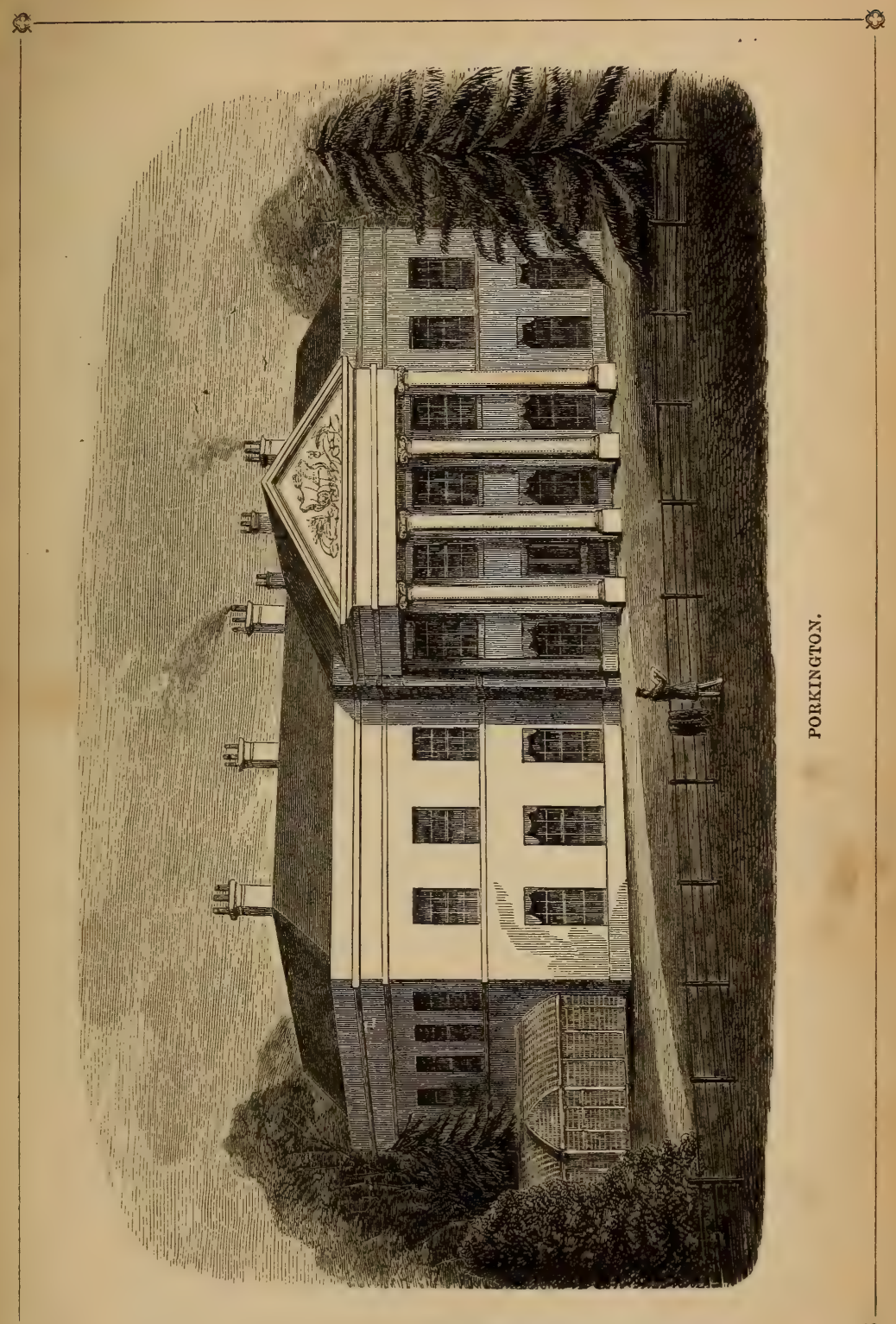





\section{PORKINGTON.}

Porkington is also historically connected with the distinguished royalist Sir John Owen, of Cleneney, Caernarvonshire, a man whose history reveals unshaken fidelity to the unfortunate Charles I., and a courage undaunted amidst the most trying reverses. A short biography of this eminent man will not be deemed out of place in these pages. Sir John Owen was the eldest son of John Owen, Esq. of Cleneney, and was born in 1600. His father had been secretary to the great Walsingham, and had amassed in his service a fortune of $£ 10,000$, a large sum in those days. He married Ellen Maurice, the heiress of Cleneney and Porkington, about 1597. Their son John entered the army, and soon distinguished himself. At the siege of Bristol he greatly signalized himself, and was severely wounded in that engagement. Throughout indeed the wars against the Common Wealth he proved himself a faithful and valiant commander on behalf of the king. At the famous battle of Llandegai, near Bangor, Caernarvonshire, fortune declared against him, and he was taken prisoner. This victory was considered by the Cromwell party of so much importance that Captain Taylor, who communicated the intelligence to Parliament, was rewarded with $£ 200$ from Sir John's estate. He was conveyed to Windsor Castle, where he found incarcerated four of his gallant compatriots, namely, the Duke of Hamilton, the Earl of Holland, and Lords Goring and Capel. All these prisoners were put upon trial, and Sir John Owen maintained a firm and heroic spirit during the enquiry that eventually saved his life. On being asked by the Court for his defence, he said " he was a plain gentleman of Wales who had always been taught to obey the king; that he had served him honestly during the war; and finding many honest subjects endeavouring to raise forces whereby they might get him out of prison, he did the like." He was condemned to lose his head, and at the conclusion of the sentence he bowed to the Court and gave his humble thanks. A bye-stander, marking his intrepid conduct, asked him what he meant, when Sir John replied267 


\section{PORKINGTON.}

"It was a great honor to a poor gentleman of Wales to lose his head with such noble lords, for he was afraid they would have hanged him." Strong remonstrances were made in Parliament on behalf of the duke and noble lords, but, finding no one speak in favour of Sir John Owen, Ireton rose as his advocate, and told the house " there was one person for whom no one spoke a word, and therefore he requested that he might be saved by the sole motive and goodness of the house." Ireton's appeal was effectual, and Sir John was pardoned after a few months' imprisonment, and permitted to return to his native country. He died in 1666, and was buried in Penmorfa Church, Caernarvonshire, where a monument is erected to his memory. The estates of Sir John Owen are possessed by his lineal descendant, Mrs. Ormsby Gore, and many interesting relics of the gallant knight are preserved at Porkington. Among these are his official seal as Vice Admiral of North Wales, and a sword given him by Lord Capel with the following inscription:- "Lord Capel, the day before his execution, presented this sword to Sir John Owen, by whom, he said, he was convinced it would be worn with honour." His portrait is also preserved at Porkington, from which the engraving, in Pennant's quarto edition of his tours, was made.

Porkington is chiefly indebted to the wife of Mr. Ormsby Gore (daughter and heiress of Owen Ormsby, Esq., who married the daughter of William Owen, Esq., and Mary Godolphin), for its present beautiful appearance. The mansion having been built at three several periods presented a confused mass, until the alterations made by Miss Ormsby conferred on it a correct Grecian elevation. The present worthy owner assumed on his marriage the name of Ormsby, prefixed to his own, and has added largely to the demesne, and to the well-timbered and romantic appearance of the hills which environ the rear of the building, the sight from the north-east and south giving extensive views over the counties of Denbigh, Chester, and Salop. 


\section{SELATTYN.}

On the pediment of the portico are the arms of the present possessors in alto-relievo. The principal stair-case is lighted by a dome of stained glass, exhibiting the names and arms of different proprietors, with the dates of their occupancy, and the names and arms also of various heiresses connected therewith, namely, Laken, Maurice, Owen, Anwyl, Wynne, Godolphin, Ormsby and Gore. The reception rooms are furnished with remarkable elegance and taste. In the saloon is the full-length portrait of Mrs. Siddons, a singularlyfaithful likeness, and also a curious painting on panel, being the only portion saved of the Altar-piece of Valle Crucis Abbey.

The views from the Terrace at Porkington are extensive and highly picturesque, displaying a variety of rich landscape scenery. In the foreground (now attached to the Porkington estate) is Old Oswestry, the Hen Dinas of the Welsh, (and in still more ancient periods Caer Ogyr-fan, from Ogyr-fan, a hero contemporary with Arthur,) a densely wooded hill, and supposed to have been a strong fortification of British or Roman origin. It is situated on the range of Watts' Dyke, which served as a boundary to the neutral ground on the Welsh side. It is surrounded by three deep entrenchments, one above the other, in which are two passes, north and south, to aseend to a very extended plain on the top of the whole, encompassed with fortifications \&c., comprising upwards of forty-two acres of land. The sides of the entrenchments are closely wooded, and carefully preserved by $\mathrm{Mr}$. Ormsby Gore, who has also planted an adjacent hill on the other side of the valley.

The parish of Selattyn, in which Porkington stands, is divided into two townships, deriving their names from the same source, namely, Upper Porkington and Lower Forkington.

\section{SELATTYN \& HENGOED.}

\section{SELATTYN,}

Or Sylattin, is a parish in the upper division of Oswestry, a rectory remaining in charge, in the diocese of St. Asaph and 269 


\section{SELATTYN.}

the deanery of Marchia. The village is situated about two miles from the Great Western Railway Station at Preesgwene, and three miles north-west of Oswestry. The population of the parish has greatly increased within the last forty years, much land, hitherto waste, has been brought into a profitable state of cultivation, and many neat and convenient cottages have been built. During the long residence in the parish of the late Rev. G. N. K. Lloyd, rector, who died in his sixtieth year, on the 17th January, 1846, the social condition of his parishioners was greatly improved, as he was constantly engaged for their benefit in every "good word and work," In October 1846 a water-ram was erected at the expense of his nephew, the Rev. Albany R. Lloyd; by which means the water is forced up, from a fine spring some distance off, to the rectory, and on towards the village, for the convenience and comfort of the inhabitants.

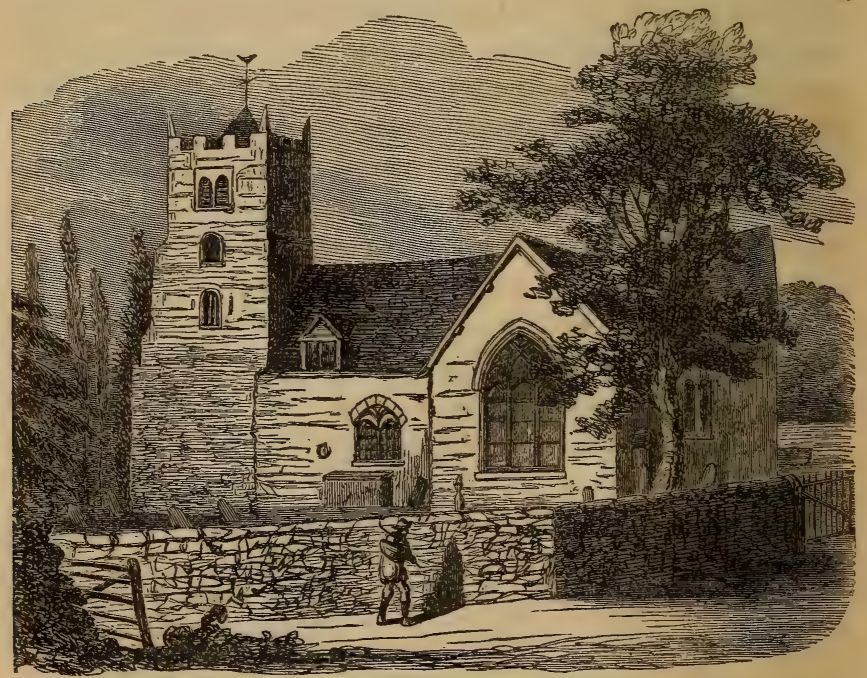

SELATTYN CHURCH.

The village is romantically situated. The church and school, the small collection of dwellings, with the little 270 


\section{RECTORS OF SELATTYN.}

picturesque valley leading to it, and the brook, which empties itself into the Morlas, rolling its limpid stream over a rocky and pebbly bed, are all delightful features of the scene. In the church-yard some beautiful and aged ash-trees expand their immense arms over the precipice beneath, while a noble avenue of lime trees adorns the northern side, and several lofty firs enrich the southern. There are also several ancient yews, which add solemnity to this interesting spot. On the hills above Selattyn are two large carneddu, with lesser ones near to them.

The erection of the steeple of the church was commenced upon in 1703. In 1821 a north transept was added to the fabric, and in 1828 the south transept was built. A new organ, built by Bryceson, was placed in the church in 1847 .

A whimsical derivation of the name of the place is given by the late John Davies, Esq., Recorder of Oswestry :- "A schoolmaster having set up here, and finding that few pupils attended, imagined that people did not know of him, but passed on to Oswestry, wrote over his door, 'I sell Latin!" "' Whether this was veritably the origin of the name we are unable to prove, but, as Mr. Davies adds, "if not the best, it is not worse than some derivations which may be found."

We subjoin a list of the rectors of the parish since 1537 , including the appointment of the fiery meteor Sacheverell, whose career we have noticed in preceding pages :-

\section{LIST OF RECTORS.}

\begin{tabular}{|c|c|c|c|c|c|c|c|c|}
\hline John ap Robert - & - & $=$ & - & - & - & - & - & {[} \\
\hline Robert Stanley & - & & - & - & - & - & - & 1537 \\
\hline T. Thomas & - & 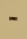 & - & - & - & - & - & 1556 \\
\hline Robert Powell & - & - & - & - & - & - & - & 1557 \\
\hline Richard Price - & - & 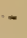 & - & - & - & - & - & 1578 \\
\hline Thomas Topperly & - & - & - & $\sim$ & - & - & - & 1587 \\
\hline William Horton ( & & Sv & & - & - & - & - & $\longrightarrow$ \\
\hline Rowland Thacker & - & - & - & - & - & - & - & 1592 \\
\hline Henry Jones & - & - & - & - & 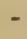 & - & - & 1600 \\
\hline $\begin{array}{l}\text { James Wilding - } \\
271\end{array}$ & - & - & - & - & - & - & - & 1610 \\
\hline
\end{tabular}




\section{HENGOED.}

Thomas Wilding
John Jones

\section{HENGOED,}

In the parish of Selattyn, is situated about two miles north of Oswestry, and has derived much interest from the recent erection of a neat and convenient church, dedicated to St. Barnabas, built chiefly at the expense of the Rev. Albany Rossendale Lloyd, the present much-respected Incumbent, aided by a few subscriptions. The foundation-stone was laid by the Rev. A. R. Lloyd, Aug. 16th, 1849; the church was opened for divine service June 11, 1850 ; and was consecrated by the Right Rev. Dr. Thomas Voule, Bishop of St. Asaph, August 15th, 1853. A district, with a population of about 650 persons, has been legally assigned to this church, and was duly gazetted January 31st, 1854. An excellent Sunday-school is attached to the church, and was originally used, until the present church was completed, as a place for divine worship.

The amount rated to the poor for the parish of Selattyn, for the year ending 25th March, 1855, was 1s. 3d. in the pound. The annual rental of the land and buildings is fixed at $£ 6,974$; rateable value, $£ 6,5016$ s. $8 \mathrm{~d}$. ; and the estimated extent of acreage, $5,434 \mathrm{a}$. $3 \mathrm{r} .13 \mathrm{p}$.

\section{ST. MARTIN'S}

Is a parish situated about five miles from, and in the hundred of Oswestry. It is a vicarage discharged, in the diocese of St. Asaph, and deanery of Marchia. The great tithes were 


\section{ST. MARTIN's.}

given by one of the Fitz-Alans to the Monastery of Oswestry, Album-Monasterium. They afterwards became the property of the Duke of Powis, and now belong in part to Viscount Dungannon. The living is a vicarage, and is valued at $£ 9$ 8s. 8d., but, having received Queen Anne's Bounty, is discharged from payments. The church is dedicated to St. Martin. The tower is a handsome building of freestone, but the body of the church is of rubble stone, and very inferior in appearance. In 1811 the church was new pewed, when a gallery was also erected, and the same year the late Lord Dungannon made a present of an organ. In the roof of the chancel were several beautiful wood-carved images, but they were destroyed by some merciless churchwarden. The Bishop of St. Asaph had a palace here, but Owen Glyndwr burnt it when he laid waste the county of Salop. In the Mostyn library is a Welsh manuscript on parchment, of the life of St. Martin. It was translated from the Latin by John Trevor, a writer who flourished between 1430 and 1470. In the parish are two schools, one founded by William ab Royd, Merchant Taylor, for fifteen poor children, and the other by the late Viscountess Dungannon, on the Lancasterian plan, for twenty poor girls. The poor-rate return for the year 1855 shows that the acreage of the parish is 5,315 ; the gross rental, $£ 10,01613 \mathrm{~s} .9 \mathrm{~d}$.; and the rateable value, $£ 9,5344 \mathrm{~s} .3 \mathrm{~d}$. The present Vicar is the Rev. William Hurst.

In the village called The Lodge, in this parish, a school was erected in the year 1851, and has been productive of much good among the humbler portion of the inhabitants.

In the parish of St. Martin's there are several beautiful residences, among which may be enumerated Preesgwene, The Quinta, Tyn-y-Rhos, and Greenfield Lodge.

Preesgwene House is historically connected with the Border Lands. It is the property and residence of J. R. Powell, Esq., is a neat mansion, embosomed in rich foliage, 273 
and situated four and a half miles from Oswestry. The house was built in the sixteenth century, by E. Phillips, Esq., an ancestor of the present possessor. The Rev. Robert Williams, in his "Biographical Dictionary of Eminent Welshmen," states that "Gwên, the most valiant of the twenty-four sons of Llywarch Hên, was slain on the ford of Morlas, a brook which rises in Selattyn mountain, near Oswestry, and flows into the Ceiriog. The name of Gwên is preserved in Prys Gwên, a gentleman's residence near the Morlas, in the parish of St. Martin's." Llywarch Hên is said to have died in the parish of Llanvor, near Bala, where a secluded place called Pabell, or the cot of Llywarch Hên, is still pointed out. He was a British Prince by birth, and a distinguished bard, as already stated. [See pp. 8 and 9.]

The Quinta was for many years the residence of the late Hon. Frederick West, (a gentleman whose virtues and honour endeared him to all who had the privilege of his acquaintance,) by whom it was greatly improved. This delightful estate was purchased by Thomas Barnes, Esq., M. P, for Bolton, Lancashire, one of the most successful manufacturers of that county. In his hands the property has undergone still further improvements.

TyN-y-Rhos, the seat of the Rev. John Croxon Phillips, is an ancient mansion. In 1164, the reign of Henry II., Owen (or Owain) Gwynedd, Prince of North Wales, slept at this house, and granted to the owner certain privileges already described. [See p. 24.]

Greenfield Lodge is a pleasantly-situated villa, the property, and formerly the residence of F. W. Smith, Esq., Agent to F. R. West, Esq., M.P. The house is approached by a remarkably fine avenue.

\section{WEST FELTON}

Parish comprises many beautiful residences, including PradoE, the seat of the Hon. Mrs. Kenyon (widow of the late Hon. 


\section{WEST FELTON.}

Thomas Kenyon, third son of Chief Justice Lord Kenyon); Woodhouse, the fine old mansion of W. Mostyn Owen, Esq.; Tedsmere, a house belonging to T. B. Bulkley Owen, Esq.; and "The Nursery," formerly the residence of J. F. M. Dovaston, Esq., but now possessed by John Dovaston, Esq., the inheritor of the Poet's estates. The parish church is dedicated to St. Michael the Archangel, and is of great antiquity, the nave being of Norman date. Within the last few years a new aisle on the north side, in the early English style, has been erected. At the east end of it there is an elegant triplet filled with stained glass of early English character, displaying scriptural subjects in medallions. Other improvements have been made in the church from designs by Mr. G. G. Scott. Near Haughton, in this parish, large quantities of earthenware have been discovered, of various colours, blue, red, green, and yellow, and highly glazed. Their origin or purpose remains a mystery, but is still worthy of antiquarian investigation. Sandford Hall, in this parish, was formerly the residence of the celebrated "Bumper Squire Jones," the hero of the once popular song of that name.

The present rector is the Rev. T. Hunt, According to the poor-rate return for 1855 the acreage of the parish is 5,989 acres 2 roods; the gross rental $£ 10,04810$ s.; and the rateable value assessed to the relief of the poor, $£ 7,9486$ s.

\section{WHITTINGTON}

Is a charming village, possessing all the beauties which give pleasure to the lovers of inland rustic scenery. Picturesque cottages, neat dwellings for people in retired circumstances, good-looking farmers' homesteads, the village church, in silent repose, surrounded by its grave-yard, and finally, the vestiges of its ancient Castle, once the baronial and stately residence of the renowned Norman Chief Fitz-Gwarine, and the scene of many a romantic story, give to Whittington village a lively interest in which all who can leisurely view it must 


\section{WHITTINGTON}

participate. It is situated upon the turnpike-road from Oswestry to Ellesmere, and two and a-half miles from the former, and five and a-half from the latter. The Great Western Railway passes through the village, where there is also a station, the trains stopping there several times a day.

Its antiquity extends so far back as the year 590, when, as the Welsh poet Llywarch Hên states, it was known by the name of the White Town (Drev-Wen.) In the reign of Rhodri Mawr (Roderick the Great,) king of all Wales, A.D. 843, a British Chieftain (Ynyr ab Cadfarch) built the Castle, which was afterwards possessed by his son, Tudor Trevor, subsequently Earl of Hereford. Tudor Trevor's mother was grand-daughter to Caradog Vreichvas, who fell in the memorable battle at Rhuddlan Marsh, A.D. 795. The descendants of Tudor continued in possession of the Castle for many generations, and several of the leading families in North Wales can trace their origin to him. At the conquest Whittington became the property of Pain Peverel, and afterwards of Roger, Earl of Shrewsbury. The Castle and lordship next passed into the hands of Hugh, and subsequently of Robert, both sons of Roger, the before-named Earl. On the defeat and forfeiture of Robert, by an Act of Henry I., the property was restored to the Peverels, in the person of Sir William Peverel, distinguished for his noble and valiant enterprises. He had two daughters; the youngest, named Mellet, of martial spirit, resolved to wed no one but the knight greatest in valour, and her father published this declaration, promising Whittington Castle as her dower. This announcement attracted the attention of many a gallant youth, and soon afterwards Peverel's domain at the Peak, near Castleton, Derbyshire, was the scene of contention for the fair prize. Among the combatants were a son of the King of Scotland, the Baron Burgoyne, and a noble Lorrainer, Gwarine de Metz, (Sheriff of Shropshire, and chief Counsellor to the Earl of Shrewsbury,) the latter of whom appeared with a shield of 


\section{WHITTINGTON.}

silver, and a proud peacock on his crest! To him the spirited Mellet was sincere, he having been declared victor. The son of this chivalrous pair was "famed for deeds of arms," and their posterity, for nine generations, assumed the christian name of Fulk, and the common name of Fitz-Gwarine. The Castle of Whittington was possessed by the family from the end of the reign of Henry I. till the reign of Henry VIII. Gwarine de Metz died in the reign of Henry I. at Alberbury, the Abbey of which place he had founded, and there he was interred, his wife, the famous Mellet Peverel, and her son, the first Fulk Fitz-Gwarine, being present on the affecting occasion.

This youth was as distinguished, in the arts of love and war, as his father. He became desperately enamoured with Hawys, the daughter of Sir Joos, of Normandy ; rescued the father from impending death, while in the hands of Walter Lacy and Sir Arnold de Lis, two inveterate enemies, and, as a reward for his gallantry and courage, received the hand in marriage of his beloved Hawys. Fulk Fitz-Gwarine was heroic in all his achievements, was knighted by Henry I., made steward of the King's Household, ard Lieutenant of the Marches. In a skirmish with the Welsh, under Grufydd ab Cynan, he was defeated, and Whittington Castle fell into their hands. In the reign of Henry II. peace was made with Owen Gwynedd, the succeeding Prince of North Wales: the Castle was retained by $\mathrm{O}$ wen; and as some compensation for his loss, Fulk had the manor of Alston, in Gloucestershire, bestowed upon him. It is recorded, says the Rev. W. Davies, in his interesting " History of Whittington," that "Fulk FitzGwarine, and John, son to Henry II. (afterwards King John,) were playing at chess together, when it happened that they disagreed, and the Prince gave Fulk a severe blow upon the head with the board, which the latter returned in such a violent manner as almost to kill the young Prince, a circumstance, had it happened, not much to be regretted, were it not in consideration of the glorious Magna Charta afterwards 


\section{WHITTINGTON.}

obtained from him." Dovaston, in his fine descriptive poem, entitled "Fitz-Gwarine," makes his hero describe the quarrel in the following lines:-

"Enough to name our last affray,

The Prince his temper lost at play,

The chess-board swung with coward sway,

And hurl'd my head upon ;

Ill could the wrong my bosom brook,

I sent him first a furious look,

Then firm with knuckles clench'd I strook

The pate of royal John."

Fulk Fitz-Gwarine was succeeded by his eldest son, who bore the same name, and eclipsed his father by the brilliancy and skill of his military enterprises. He accompanied Richard I. in the Crusades, and was made Lord Marcher of Wales. At the commencement of King John's reign Whittington was in the hands of Maurice, brother to the Roger to whom Owen Gwynedd had presented it. Fulk Fitz-Gwarine applied to John for the restoration of the ancient property of his ancestors; but John rejected his application. Indignant at this treatment Fulk joined the Welsh sovereign, made battle against Maurice, in which the latter was slain. The English King determined upon having Fulk Fitz.Gwarine put to death, but the latter fled to France, under the nom de guerre of Sir Amice, a wandering knight, and was so much admired by the French monarch for his honourable and chivalrous conduct, that he tendered to him a barony of France. After having performed many acts of valour and renown in France, Fulk returned to England, determined to see King John and propitiate his favour. Fearing discovery, he exchanged clothes with a peasant, and wended his way to Windsor, to confront the monarch. In Windsor Forest they both met, John being out hunting, and Fulk appearing before the King as a peasant. Fulk made known to him his errand, and declared that he was the obnoxious Fitz-Gwarine; with the courage and dignity of his race he menaced the king for the unjust treatment he had received, and forced him to restore to his undis- 


\title{
WHITTINGTON.
}

turbed possession the Castle and lordship of Whittington, his ancestral property. John immediately repudiated his grant, and Fulk was again compelled to leave the kingdom, having been pursued by emissaries of the monarch, charged to slay him. Fitz-Gwarine was still as adroit as he was brave; he killed the man who meditated his assassination, fled to Orkney, where he released a persecuted female from her captivity, and won a hauberk of hard steel, which, with other ancient pieces of armour belonging to his family, hung, till Cromwell's wars, in the church of Whittington. From Orkney Fulk sailed to Carthage, where he derived much information, his patriotism was inflamed, and where also his enthusiastic desire for the improvement of his native country glowed with increased ardour. Wrapt in these visions of future glory and happiness, he re-embarked for England, arrived safely, appealed again to King John, obtained pardon for all past offences, and with it the restoration of Whittington Castle and all its appendages. Thus once more in possession of his ancient halls, he lived in the state and hospitality which became his princely condition. Then, as the author of "Fitz-Gwarine" so sweetly sings-

\author{
"Other guests than yon lone bird, \\ And other music here were heard, \\ In times of better days; \\ Festive revelry went round, \\ The board with blushing goblets crown'd, \\ And costly carpets clad the ground, \\ Where now yon cattle graze. \\ Days were those of splendour high, \\ Days of hospitality, \\ When to his rich domain \\ Welcom'd many a crested knight, \\ Welcom'd many a lady bright, \\ Fitz-Gwarine of Lorraine!"
}

This remarkable man was afterwards sent by the English King to Ireland on an important service, and was distinguished on his return, with the title of The Great. He subsequently united with the English Barons in their memorable demand 


\section{WHITTINGTON.}

from King John of Magna Charta, and so resolute was his conduct on that great occasion at Runnymede, that the Pope actually conferred upon him the honour of excommunication from the papal church.

After various other conflicts and disasters, "by flood and field," he descended into old age, when he was stricken with blindness. He was buried in the porch of Whittington Church, and his remains were found there in an oak coffin, three inches in thickness, by digging a grave in the year 1796 . He left behind him a son who enjoyed his father's estates and titles, but for no considerable time. He followed Henry III. through all his adverse fortunes, and whilst engaged at the battle of Lewes was drowned in crossing a river, leaving behind him a young son, the fourth Fitz-Gwarine.

Fitz-Gwarine the second was married to Clarice of $\mathrm{Ab}$ bourville, and he went generally by the peculiar appellation of Proud-homme, as a mark of respect to his nobility.

Whittington Castle, after the battle of Lewes, was bestowed by the Earl of Leicester upon Peter de Montford. Leicester also compelled the captive king Richard II. to deliver it, with other Border Castles, into the hands of Lilywelyn ab Grufydd, Prince of Wales, who had just received the entire sovereignty of Wales, and required homage from all the barons under him.

The subsequent history of the Fitz-Gwarines presents but few interesting features. This illustrious race became extinct at the death of Henry, fifth Earl of Bath (who inherited the title of Fitz-Gwarine through the marriage of Elizabeth, sister and heiress to Fulk the ninth, with Richard Haukford, Esq.,) and the manor, after various transfers in succeeding ages, was purchased by Francis (or William) Albany, Esq., of London, from one of the Earls of Arundel, it having been granted to him by Queen Mary, but afterwards mortgaged and sold. The manor, advowsons, and estate of Fernhill passed subsequently to the house of $A$ ston, by the marriage of 



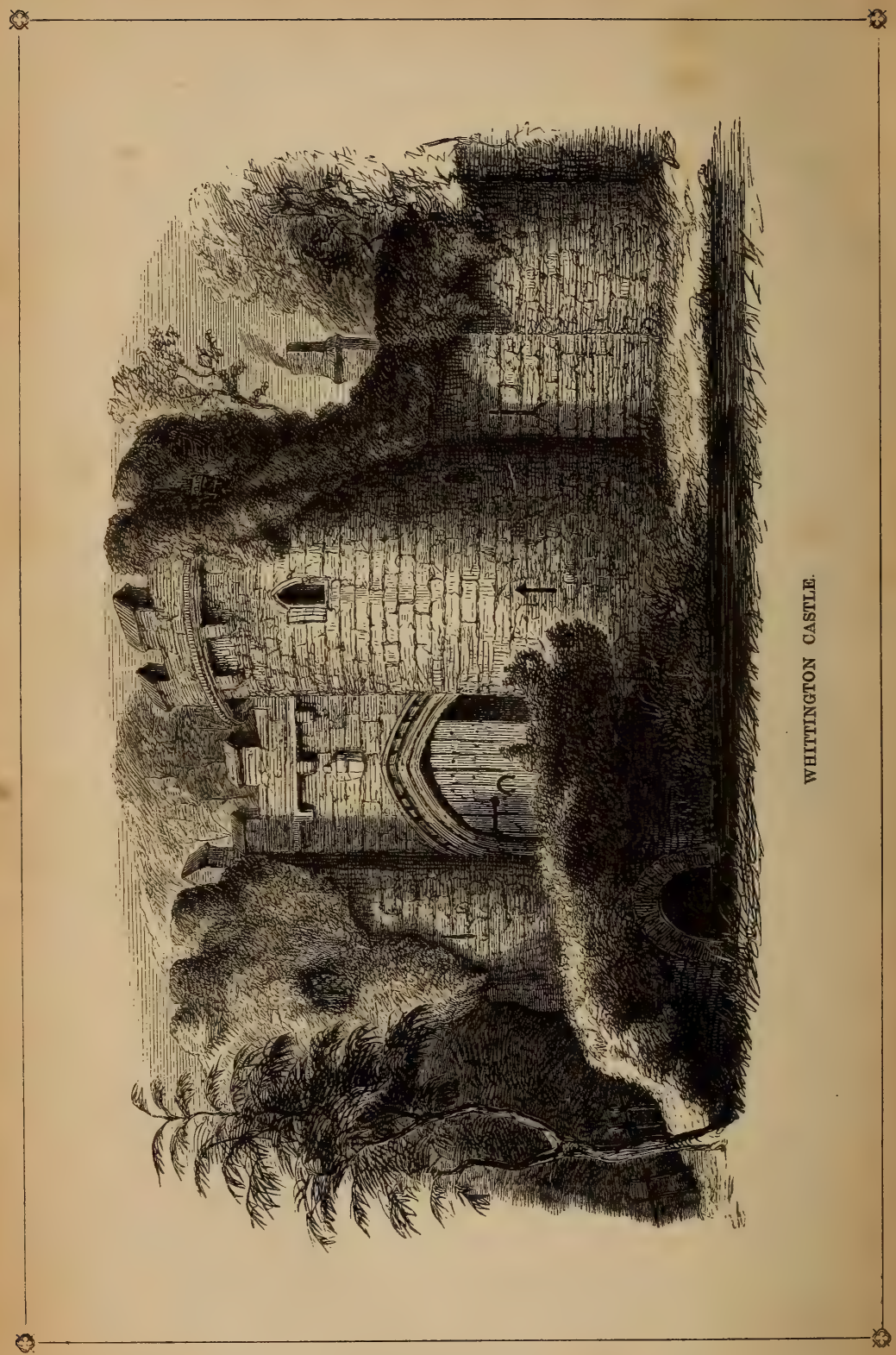




\section{WHITTINGTON.}

Sarah, daughter and heiress of the said Francis Albany, Esq., to Thomas Lloyd, Esq., of Aston. In the year 1760 the eastern tower of the Castle fell into the moat after a severe frost, and some years afterwards one of the northern towers and the western wall were taken down to repair, it is said, the road leading from Whittington to Halston bridge.

The remains of the Castle are still a picturesque ruin, which attracts artists from all parts of the kingdom to sketch its lingering beauties. Our own artist has done justice to the Castle in the sketch he has taken. The towers of the gate-house are still entire, and part of the ancient building is converted into a dwelling, and occupied by Thomas Broughall, Esq. A running brook passes through the moat, which is overhung with fine old trees, casting their shade upon the waters. In the year 1796 three curious bottles, richly gilt, were found, and subsequently, in clearing the bottom of one of the old towers, some huge iron fetters, a gyve of ponderous size, with a number of the heads and antlers of deer. The Castle, from its position on the frontier of Wales, and from the warlike spirit of its lords, was in feudal times a place of great consequence, and, like other border fortresses, alternately the scene of clashing arms and knightly festivity.

The church, which is dedicated to St. John, is a rectory in the archdeaconry and diocese of St. Asaph, and was originally designed as a chapel to the castle. The body of the church was rebuilt in 1805, from a design by the late Mr. Thomas Harrison, architect, of Chester. It is a large brick building of 60 feet by 50 , and cost $£ 1500$. To lessen the expense of building the church two briefs were procured that raised $£ 70315$ s. 1 d., but of this sum only $£ 42$ 2s. 1 d. was received. In 1810 a new organ was erected in the church. In the same year the church-yard wall, being much out of repair, was rebuilt with stone. The Rev. Charles Arthur Albany Lloyd, who had filled the office of Rector for many years, died July 24th, 1851, he being also Rector of Selattyn at the time. 


\section{WHITTINGTON.}

Whittington parish is divided into nine townships, namely, -Whittington to the south; Berghill and Francton (or Frankton) to the east; old Marton (or Martin), Hindford, Henlle, and Ebnall, to the north; and Fernhill and Daywell to the west.

In a manuscript description of the parish we find the following derivation of names:-

Whitmington, or White Town, from White Castle, in Welsh, Drewen.

Berghill-Welsh, Byr-Ghill, or Short Hazles. HiNDFord- " Hen-fordd, or The Old Road.

Henlle- " Hen, old, and Lle, Place.

DaYwell- " Fynnon du, or dydd. Day Spring (or well).

Fernhill- , Fwrn and Oven, or Hole and Hill.

A tradition long prevailed in the village, that it was the birth-place of the renowned Sir Richard Whittington, "thrice Lord Mayor of London town." It is now, however, generally understood that he was born in the township of Newnes, (not far from Whittington,) about one mile north-west of Ellesmere. Shropshire claims him for her own; and if Whittington really was "a proud Salopian," the county has a right to be proud of the honour of enrolling among its worthies so distinguished a name. Another vague tradition prevailed, that the well-known metrical tale of "The Babes in the Wood" derives its origin from Babins' wood, (commonly called Babbys' wood,) near Whittington. The tradition adds, that the murder of the two children by their cruel uncle was perpetrated at this place. Gough, the historian of Middle, relates particulars of the murder of a child by its uncle, but his account is only from tradition, and therefore mixed up with much error.

The version we now give of this murder, derived from an authentic source, shews that the ballad of the Babes in the 282 


\section{WHITTINGTON.}

Wood could not have been founded upon it. The scene of the nursery rhyme is laid in Norfolk, and all the circumstances it details differ materially from those of the murder at Knockin heath. The version we have is as follows:- " 1590,27 th March.-A man and woman were executed at Knockin heath, for murdering a child of the age of five years, for his land, being an heir of $£ 5$ a-year, or thereabout, which fell after the said child's death, if he died without issue, to his uncles, being three of them, which uncles procured and imagined the death of the said child ever since his birth. Two of the uncles were executed at Bridgenorth assizes, and the third pressed to death there. But the woman being grandmother to the child, and the man named Geffrey Elkes, being hired to do the deed, were executed at the said heath where the said deed was done." "Elkes, at his execution, affirmed that he did not kill the child, but brought a pail of water to the heath, and left it there with the child and the uncle that was pressed to death, but he confessed that before the deed was done, and after, two ravens usually would meet him, follow him, and cry about him ; and when he escaped and hid himself, the said ravens did cry, and flew about the place, and descried him out, and he was found in a cock of hay by their - means."

The parish register is a curious record of odds and ends, and from it we make a few quaint selections:-

“ Died March 1lth, 1767.-Thomas Evans, parish clerk, aged 72.

' Old Sternhold's lines, or Vicar of Bray,

Which he tun'd best is hard to say.'

I do make choice of William Evans, his son, to serve the office of parish clerk, being qualified according to the 91 st canon, viz : above twenty years of age, and of an honest conversation, and very sufficient for his reading, writing, and also for his competent skill in singing, tho' not so clever a piper as his father. This choice was signified to the parishioners in time of divine service, on Sunday, the 15th day of March, 1767.

(Signed) by me, W. Roberts, Rr." 


\section{WHITTINGTON.}

"1776.-ANDREW WILliams, in Whittington, aged 84, Decoy-man under the Aston family, at the Decoy, in this parish, above 60 years :-

"Here lies the Decoy-man, who liv'd like an otter,

Dividing his time between land and water:

His hide he oft soak'd in the waters of Perry,

Whilst Aston old beer his spirits kept cheery ;

Amphibious his trim, Death was puzzl'd, they say,

How to dust to reduce such well-moisten'd clay.

So Death turn'd Decoy-man, and decoy'd him to land,

Where he fix'd his abode till quite dried to the hand;

He then found him fitting for crumbling to dust,

And here he lies mould'ring, as you and I must."

"Samuel Peate, of Whittington Castle, died, aged 84.

"Here lies Governor Peate,

Whom no man did hate,

At the age of four-score,

And four years more,

He pretended to wrestle

With Death, for his castle,

But was soon out of breath,

And surrender'd to Death,

Who away did him take,

At the eve of our Wake,

One morn about seven,

To keep Wake in heaven."

"Nov. 29th, 1780.-SARAH Browne, of Babe's Wood, widow, aged 76.

"E P I T A P H.

"Here lies Mammy Brown,

Who oft sung ding and down

Over many a brat :

And what of all that?

Why she sung herself down,

So here lies Mammy Brown.

N.B.-She nursed many children besides her own."

There are several useful and important charities pertaining to Whittington parish. Jones's charity of 1670 , and Griffith Hughes's bequest in 1706, provide for the education of the 


\section{WHITTINGTON.}

boys of the parish, as that of Elizabeth Probert does for the girls. These bequests are now applied to the National Schools established in the village.

The old National Schools being too small for the increasing population of the parish, a new School House, for the accommodation of Boys and Girls, was erected in the year 1853, on the site of the former Boys' School, at a cost of $£ 900$, after a design by Messrs W. and J. Morris, Builders, \&c., of Oswestry, by whom also the structure was erected. The present much-respected Rector is the Rev. William Walsham How, who purchased the living in the life-time, and succeeded to it on the death, of the Rev. C. A. A. Lloyd.

The parish of Whittington contains 8,303a. 3r. 10p.; gross rental, $£ 13,1455$ s. 0 d. ; rateable value, $£ 12,86710$ s، 0 d.

It is worthy of record in our notice of Whittington, that the admirable Missionary Hymn, from the pen of the late Bishop Heber, "From Greenland's icy mountains," was written especially for a public meeting of the friends of Missions, held in the village about the year 1820, at which the poet Heber attended. The hymn was sung on that occasion for the first time; but since then how many thousand voices, in every part of the habitable globe, have been raised in tuneful melodies whilst pouring forth this immortal strain! Heber's hymn ranks with the sacred songs of our best poets, and has urged many a Christian heart to the heaven-born work of spreading the gospel throughout the heathen world.

Amongst the pleasant retreats in the neighbourhood of Whittington are BeLmont, the residence of J. V. Lovett, Esq., an active and intelligent Magistrate for the county; FERNHILI, about one mile from Whittington, the seat of Thomas Lovett, Esq., also an able county Magistrate; and the Derwen, the house of John Povey, Esq., a gentleman much respected in the district. 


\section{WYNNSTAY,}

The beautiful seat of Sir W. W. Wynn, Bart., M. P. for Denbighshire, is within twenty minutes' railway ride from Oswestry. The talent, wealth, and princely hospitality of the Wynnstay family have given to this mansion and its extensive domains a national celebrity. The late Sir W.W. Wynn (father of the present worthy baronet) did much to maintain the high character for hospitality and munificent liberality for which the House of Wynnstay has ever been distinguished, and his memory is embalmed in grateful recollections by hundreds who partook of his bounty and were generously aided by his purse and patronage.

Wynnstay is situated in the parish of Rhuabon, and is erected on the site of a residence of Madog ab Grufydd Maelor, Prince of Powys, and founder of the abbey of Llanegwest, or Valle Crucis, near Llangollen. The original name of this house was Rhuabon. It was the property of Edward Eyton, Esq., whose daughter Mary, the heiress, married Richard Evans, Esq., son of Thomas Evans, Esq., of Oswestry, attorney-general in the Court of the Marches. Their grandson, Eyton Evans, (son of Thomas, son of Richard,) altered the name to Watt-stay, on account of its proximity to Watts' Dyke; and Jane, sole daughter and heiress of Eyton Evans, Esq., married Sir John Wynn, who again changed the name to Wynnstay, in compliment to his own family, he being grandson of Sir John Wynn, of Gwydir, by his tenth son, Henry, representative for Merionethshire. The above-named Sir John Wynn, of Wynnstay, left that and other estates of great value to his kinsman, the first Sir Watkin Williams Wynn, grandson of Sir William Williams, Speaker of the House of Commons in the reign of Charles II., and in the early part of his career Recorder of Chester. Sir William was one of the most successful lawyers of his time, and was a zealous and eloquent advocate of the popular party in Charles's reign. The notorious Jeffreys was reprimanded, on his knees, by him 



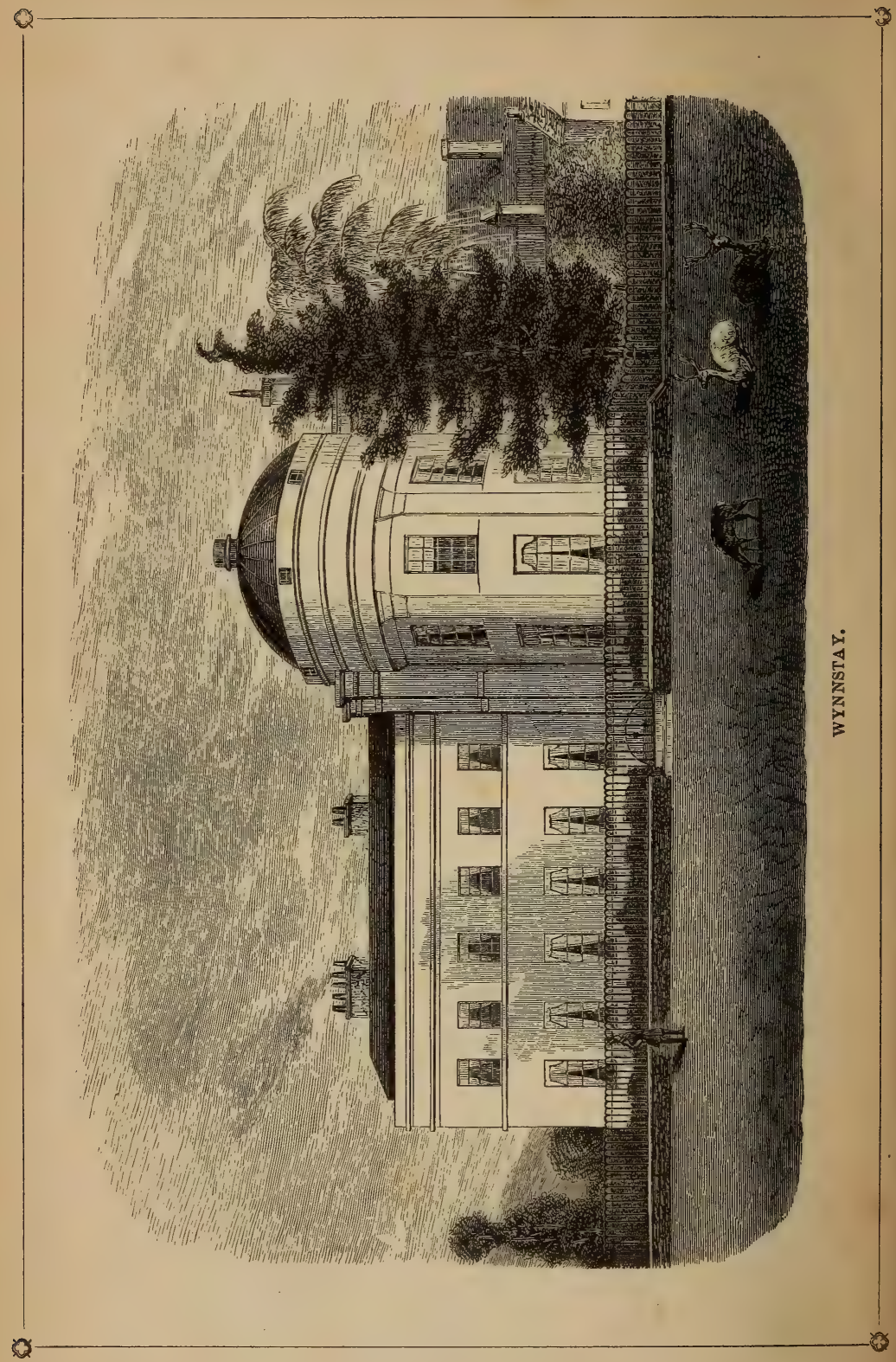




\section{WYNNSTAY.}

whilst he was Speaker of the House of Commons; who also conducted the prosecution of the Seven Bishops, when solicitorgeneral; and the "Treating Act," which still continues one of the safeguards of the purity and independence of Parliament, was introduced by him in the House of Commons. This celebrated lawyer was made a baronet in 1688 . He married Margaret, daughter and heiress of Watkin Kyffin, Esq., of Glascoed, in the parish of Llansilin, near Oswestry. He left two sons, and the elder, Sir William, of Llanforda, married another great heiress, Jane, the daughter of Edward Thelwall, Esq., of Plas-y-ward, and was father, as already mentioned, of the first Sir Watkin Williams Wynn. The Speaker's youngest son, John, was an eminent provincial lawyer, and practised at Chester, and was direct progenitor of the present Sir John Williams, of Bodelwyddan, Flintshire.

The mansion is a noble pile of building, of fine white stone, and has, recently, under the direction of the present possessor of Wynnstay, undergone much improvement. The interior comprises several noble apartments, which are embellished with paintings by the first masters, portraits of various members of the family, and busts by eminent sculptors, of the distinguished statesmen Lord Grenville, William Pitt, \&c. The library consists of a fire collection of books, in ancient and modern literature, with valuable MSS. illustrative of early British history. Among the variety of plate, including elegant race-cups, \&c., is a large silver vase, or punch-bowl, presented to the late Sir W. W.Wỳn, by his countrymen, on his return from the battle of Waterloo.

The grounds in which the house is situated are remarkable for their sylvan beauty. The avenue leading to the mansion from Rhuabon is formed of fine oak, elm, beech, and other trees, one of which, "The King," measuring thirty feet in circumference, and with its outspreading arms appearing to bid defiance to its fellows, seems to have a just claim to the monarchical title it bears. A fine sheet of water in front of 


\section{WYNNSTAY.}

the house adds much to the picturesque and deeply-wooded scenery around. Both the near and distant views from the park are distinct and attractive, those especially towards the Berwyn chain of mountains, with the grand breach in it beyond Llangollen, through which rolls the rapid Dee. An obelisk or handsome free-stone column is erected in the park, after a design by Wyatt, as a tribute of maternal affection, in memory of Sir Watkin Williams Wynn, grandfather of the present baronet. Round the entablature is a gallery, with a circular iron balustrade, nine feet high, in the centre of which stands a handsome urn in; bronze. The plinth is wreathed with oak leaves descending from the beaks of eagles. A door-way leads, by a wide stair-case, to a gallery at the top. On the lower part of the Cenotaph is the following emphatic inscription:-

\section{"Filio Optimo. \\ MATER CHEU! SUPERSTES."}

Although this column cannot be seen from the house, a glimpse of it may be caught on the left side of the railway, in passing from Rhuabon towards Oswestry. The Nant-y-Bela Tower, in "The Dingle of the Marten," is another Cenotaph, erected by the late Sir W. W. Wynn, after a design by Sir Jeffrey Wyattville, in memory of his brother officers and private soldiers slain in Ireland during the rebellion of 1798. Itstands on an eminence, and commands a view of the Vale of Llangollen, for several miles. The Waterloo Tower, close also to the xailway, is another ornament to the park.

In the days of Sir W. W. Wynn, grandfather to the present baronet, theatrical performances were often given during the Christmas Holydays, in a neat theatre near the house, erected for the purpose. David Garrick, "the British, Roscius," as he was called, frequently superintended these histrionic displays, where wit and revelry prevailed. The surrounding nobility and gentry participated in these festivities, which uniformly passed off with eclât. The late Sir W. W. Wynn divested this Thespian Temple of its ornaments, and 288 


\section{BROOM HALL.}

appropriated it for an annual agricultural meeting, as an auxiliary to the society at Wrexham. An annual show of cattle was held at Wynnstay, where premiums were adjudged, for the best of every species of stock, for ploughing the greatest number of acres, with two horses a-breast, without a driver, \&c. This bucolic fete was generally held in September, when a numerous assemblage of practical agriculturists attended. A dinner at the hall followed, where covers were laid for five or six hundred persons. The tables groaned beneath the weight of viands, including fine samples of roast beef and unctuous venison; "rosy wine" spread its charms along the festive board, and "old October," from the cellars of Wynnstay, were handed round in huge flagons worthy of the merriest days of Cambria. On these occasions Sir Watkin generally presided, and did the honours of the table with an urbanity and cheerful hospitality that endeared him to all his visitors.

The present Sir W. W. Wynn represents in parliament the county of Denbigh, is Steward of the Lordships of Bromfield and Yale, and is Lieutenant-Colonel of the Montgomeryshire Yeomanry Cavalry.

Among the more attractive residences in the immediate suburbs of the town the following claim a brief notice:-

Broom HaLl, the residence of Mrs. Aubrey, widow of the late H. P. T. Aubrey, Esq., is situated near to the town, on the west side. Mr. Aubrey died in 1848. [See p. 143.] DRENEWYDD stands about a mile and a-half from Oswestry, on the road leading to Whittington, is a very ancient house, and has some interesting historical facts connected with it. It was formerly the residence of Edward Lloyd, Esq., eldest son of Marmaduke Lloyd, Esq., by Penelope, daughter of Charles Goodman, Esq. He was eminent for his learning, and after a long and diligent search into ancient recorỏs, wrote 
a history of his native county, but did not live to publish it. A MS. copy of his learned works is preserved in the Bodleian Library, Oxford. He was elected Mayor of Oswestry in 1707; in which office, it is recorded of him, "he corrected many existing abuses." He left an only son, Charles, who was the last in the male line of the Drenewydd family. The old house at Drenewydd is now the property of William Ormsby Gore, Esq,. and is occupied as a farm house. Mount Pleasant, the seat of Thomas L. Longueville, Esq., (a gentleman distinguished for his public and private worth,) is situated about one mile from Oswestry, on the road leading to Llansilin. OAKHuRst, a newly-erected mansion, about one mile northwest of Oswestry, on the road leading to Selattyn, commands extensive and delightful views of the surrounding country, including the Vale of Salop and the Breidden hills. It is built in the Elizabethan style of architecture, and is the property and residence of R. J. Venables, Esq., one of the Magistrates of the county, and a Director of the Great Western and Oswestry and Newtown Railway Companies. The family of Mr. Venables have for many years been honourably connected with the borough of Oswestry. At RHYD-Y-CROESAU is the residence of the Rev. Robert Williams, author of "Biographical Dictionary of Eminent Welshmen." Mr. Williams is a profound scholar, and his location in the district, at the head of an ably-conducted school, may be looked upon as a great advantage to the inhabitants generally. Pentrepant, the property of T. G. Warrington Carew, Esq., is the residence of Colonel Frederick Hill. It is about one mile from Oswestry, on the road to Selattyn. The estate was for many generations in the Hanmer family, and John Hanmer, Bishop of St. Asaph, resided here. He died in 1629, and was buried in the church of Selattyn, to the poor of which parish, and also of Oswestry and St. Asaph, he gave $£ 15$ to be equally divided between them. Penylax is a very beautiful House, about one mile from Oswestry. The pleasure-grounds and shrubberies are laid out with much taste and skill. It is the 290 
residence of Mrs. Longueville, (Widow of the late T.L. Longueville, Esq.,) a lady of enlarged benevolence, and who has ever shewn herself ready to alleviate the sufferings of the poorer classes of the district. SWEENEY HaLL, situated about two miles from Oswestry, on the left of the road to Welshpool, is a handsome mansion built of freestone, and beautifully placed in the midst of a well-timbered park. The house was erected by the late Thomas Netherton Parker, Esq., a gentleman who will be long remembered as an active and impartial Magistrate of the county; as an enlightened landed proprietor; and a liberal and warm-hearted friend to the poor of his district. Mr. Parker was an able writer on agricultural and social economy, and some clever essays from his pen show how intimately acquainted he was with the condition of the rural population of all classes. He was an ardent promoter of agriculture, and most assiduously employed hinself for its practical advancement. The estate is now the property of his son, the Rev. John Parker, vicar of Llanyblodwel, and the house is occupied by Hugh Beavor, Esq. Some particulars relative to the ancient burial-ground upon the estate are given in page 153. Wood Hill $\mathrm{H}_{\text {ALL, }}$ about two miles from Oswestry, in the right of the road to Llanymynech, was formerly the property of L. J. Venables, Esq., but has recently been purchased, and is now occupied by J. Lees, Esq.

In closing our SKETCHES of the ENviRons, a brief reference to Chirk and Llangollen Vale, both being within half an hour's railway ride from Oswestry, seems to be necessary.

CHIRK is situated upon the northern bank of the river Ceiriog, and is a pleasant and somewhat picturesque village. The entire parish is the property of Col. Myddelton Biddulph. The church, dedicated to St. Mary, contains an interesting monument of the gallant Sir Thomas Myddelton; and in the church-yard are some fine yew trees, the growth of centuries. 


\section{CHIRK.}

There is an excellent inn in the village, The Chirk Castle Arms, kept by Mr. Moses, who is also post-master there. From the poor-rate return for the present year (1855), it appears that the acreage of the parish is $4,635 \mathrm{a} .3 \mathrm{r} .29 \mathrm{p}$; the gross rental, $£ 9,4018 \mathrm{~s} .4 \mathrm{~d}$. ; and the rateable value assessed to the relief of the poor, $£ 9,3082 \mathrm{~s}$. $1 \mathrm{~d}$. The present muchrespected Vicar is the Rev. Joseph Maude, who is also, as. already stated, Chairman of the Board of the Oswestry Incorporation. The Vale of the Ceiriog, like that of the Dee, generally attracts the attention of railway travellers, from its singular beauty and historical associations. It is crossed by a Viaduct of the Great Western Railway, and by an Aqueduct also, extending along the Ellesmere canal upon long ranges of arches at a considerable elevation. Llangollen Vale is only a few minutes' ride from Chirk, and, we need not add, "the admired of all observers." The tourist is amazed with the first view obtained of it; its hills and slopes display enchanting spots, and the beauty of the natural scenery is increased by the massive elegance of Robertson's railway viaduct across the Dee, and the classic grace of Telford's aqueduct. The Vale, on both sides the river Dee, is at length brought to a high state of cultivation. Looking down the valley from the railway viaduct, or from the more elevated portions of the Holyhead road, the scene presents a strange admixture of beauty and ugliness; and a stranger, for the first time viewing the scene, would declare, "I see nothing but smoke." On the north side of the river are the extensive iron works of the New British Iron Company, disgorging smoke and flame day and night, and on the opposite side of the river are the Vron limestone quarries and kilns, equally active in discharging huge volumes of vapour. The tourist must pass on from these manufacturing localities, and his eye will soon rest upon scenery of surpassing loveliness and grandeur. The wood-crowned heights of Trevor, the Eglwyseg and Berwyn range of mountains, the old battered fortress, Castell Dinas Bran, the luxuriant Vale, which presents 292 


\section{LLANGOLLEN.}

the form of a capacious amphitheatre, and the Dee, winding its course over beds of clay-slate, limestone, and granitic boulders, - these, with abundance of full-grown timber, snug villas, white-washed cottages, and well-managed farms, with fertile fields and well-farmed hill-sides, show of what materials the panoramic valley is composed. Could Moore have viewed it, as we have done on a bright summer day, he would have been constrained to quote his own beautiful line,

"The valley lies smiling before me."

Of Llangollen itself we shall attempt no description. Its charms have been transmitted to glowing canvass and sung in rapturous verse from Anna Seward downwards ; its hostelries, the Hand and the Royal Hotels, its "trouts," its mountain mutton, sparkling ale, and other delicacies, have too long been the "household words" of tourists, album-writers, and after-dinner orators, to render eulogium or even " faint praise" from us in the slightest degree necessary.

After these poetic visions it is difficult to descend to sober reality. The tourist, generally speaking, unless he be a botanist, a geologist, or an artist, penetrates little beyond the public highway, except in those localities distinguished by a waterfall, an ancient castle, or a noble residence. Thousands of people, from the manufacturing districts, cannot in their visits to the Principality do more than give a passing glance to the country through which they hurriedly travel. In the immediate vicinity of the turnpike-roads on both sides of the Dee the land there lets at a high price, and, generally speaking, is ably farmed ; and ascending the hills, to the heights of ten or twelve hundred feet, most of the little inclosures occupied by small farmers, or by parties engaged principally in other occupation than that of agriculture, are also well cultivated, and fetch a rental of from 30 s. to 40 s. per acre. Some twenty years ago the mountain-land in the Vale of Llangollen was deemed common, and but few habitations were erected 


\section{LLANGOLLEN.}

upon it; but at the present time neat cottage-dwellings for the industrious poor are raised in clusters, and most of the land attached to them is farmed with a skill and success that would put to the blush many a professed agriculturist. No doubt that this comparatively high price for mountain-land is caused by the large number of working-men employed in the various manufacturing and other working establishments in the neighbourhood. Such men require small portions of what is called occupation land, on which to feed a cow and grow a little wheat, barley, oats, and potatoes. To them the land even at the price is an advantage; but still it is a fact worthy of note, that mountain-land in this busy district is in great demand, and whenever let fetches a high rental. Such is the influence of manufactures upon agriculture, both of which, as Sir Josiah Child said years ago, "must wax or wane together." 


\section{CORRIGENDA.}

Some few typographical and other errors have occurred in the progress of the volume, which we are anxious to correct.

In page 210 , line 13 , for "old transparent," read "cool transparent."

In page 223 , line 3 , for "carbonate of zinc," read "carbonate and sulphuret of zinc."

In page 251, line 4, for "Procapella de Coton," read "Pro capella de Coten."

In the List of Illustrations, for "Corn Market," read "Cross Market."

\section{THE POST-OFFICE.}

Since our notice of the Post-Office was printed, a new postal arrangement has been made, by which Letters to the north and south can now be posted, without extra charge, till eight o'clock, p.m.; and, with an extra stamp, till half-past eight.-Money Orders can be obtained till 5, p.m.; and Letters registered till 7 , p.m. 


\section{LLANGOLLEN.}

upon it; but at the present time neat cottage-dwellings for the industrious poor are raised in clusters, and most of the land attached to them is farmed with a skill and success that , ...... kl- h.woh manv a professed agriculturist. No 



\title{
THE UNITED KINGDOM TEMPERANCE
}

AND

\section{GENERAL PROVIDENT INSTITUTION,}

FOR THE MUTUAL ASSURANCE OF LIVES, \&C.,

1, Adelaide Place, London Bridge, London.

Established 1840.

\section{ACCUMULATED CAPITAL, 125,000.}

This flourishing Institution has just completed its financial year, within which it has accepted One Thousand Eight Hundred Proposals for Assurances, covering considerably more than a Quarter of a Million Sterling. It has issued 4,640 Policies, making, since its commencement, an aggregate of more than TEN THOUSAND. Its present income is above $£ 45,000$ per annum. It has paid in claims, chiefly to the Widows and Orphans of its members, $£ 36,000$.

The Temperance and General Sections are kept separate, the members of each participating in the Profits of their respective Sections. The Office transacts every description of Life Assurance.

W. R. BAKER, RESIDENT DIRECTOR.

\section{JOHN WINDSOR, AGENT FOR OSWESTRY,}

Of whom Prospectuses \&c. may be obtained.

\section{MR. JAMES EDISBURY,}

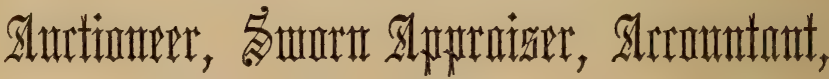

\author{
AND

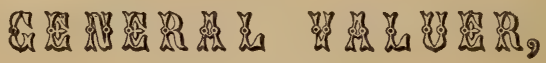 \\ rarexyam.
}

* All Sale Accounts immediately settled.-Valuations for the Probate of Wills and Administrations faithfully and promptly attended to. 


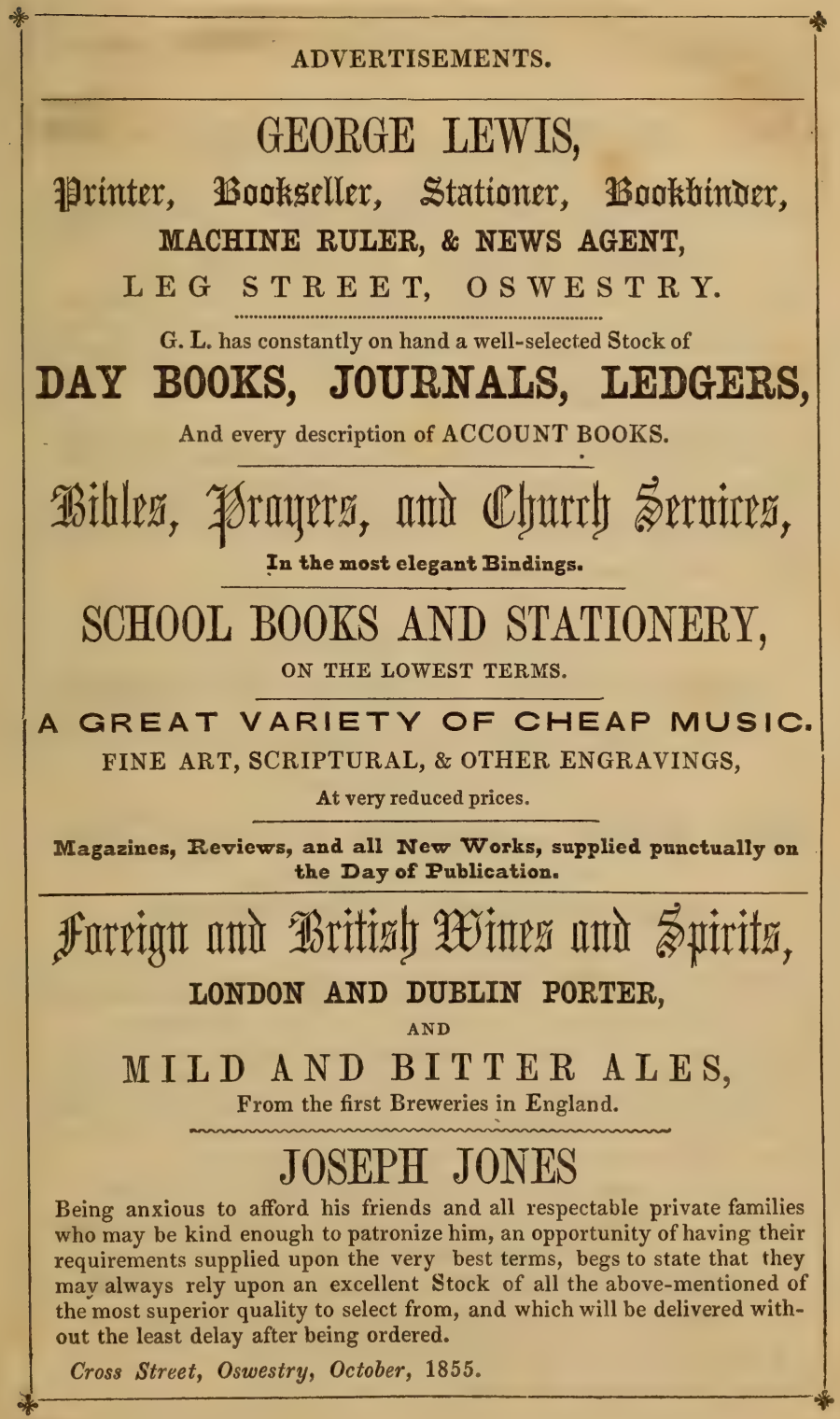




\section{ADVERTISEMENTS.}

\section{嗮illinm}

1, K I N G A L F R E D'S P L A C E, Near Bingley, Irall, Broad-Street, Birmingham, MANUFACTURER OF

\section{IMPROVED BLINDS FOR SHOP FRONTS,}

SPRING ROLLERS, from 1 to 5 in. diameter,

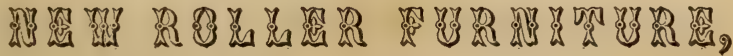
ON AN IMPROVED PRIKCIPLE, ALL SIZES,

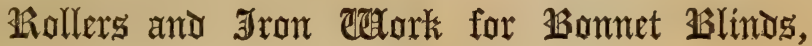
VENETIAN BLIND FURNITURE,

Cornice Poles, with Rings,

BLINDS FOR GREEN-HOUSES, SKY-LIGHTS, ETC,

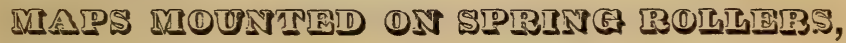

In Boxes, and every other description of

BLIND FURNITURE \& FITTINGṢ.

ESTABLISHED A.D. 1803.

\section{J. EDISBURY, \& Co.,}

(LATE RATCLIFFES)

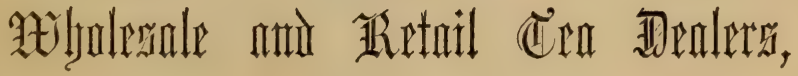
Family Grocers, CHEESE FACTORS, \&C., TOWN HILL, OPPOSITE THE TOWN HALL, WREXHAM. 


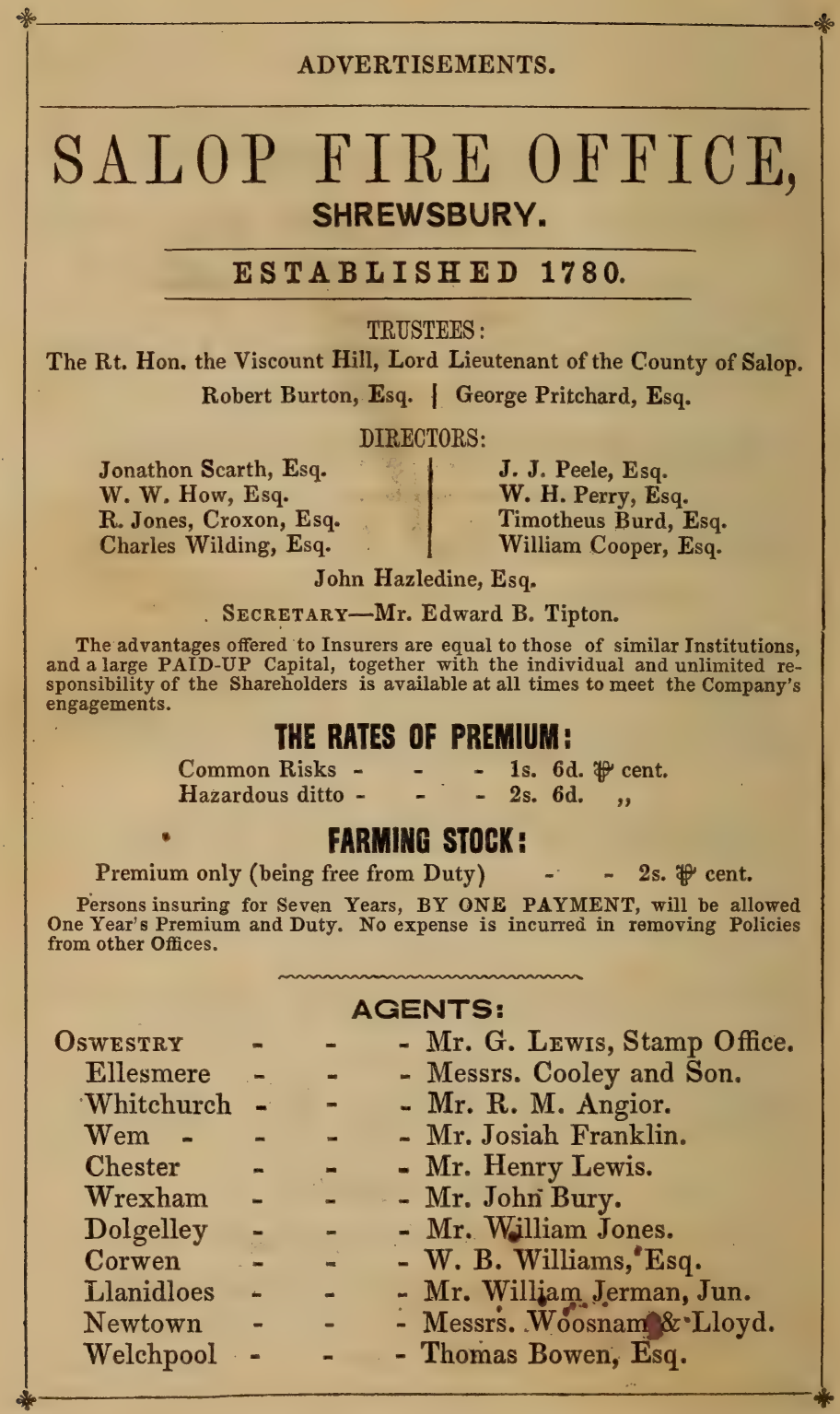




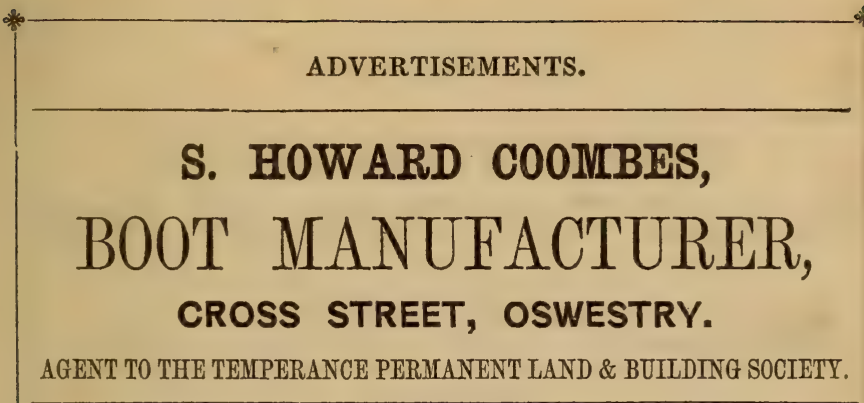

AGENT TO THE TEMPERANCE PERMANENT LAND \& BUILDING SOCIETY.

\section{JOHN WINDSOR,}

Agricultural Implement Manufacturer,

Begs to call Public attention to his

STOCK OF IMPLEMENTS, CONSISTING OF

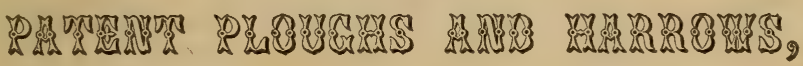

CAMBRIDGES \& PLAIN LAND ROLLERS, వCA

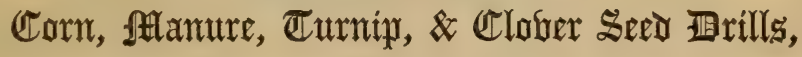

With the latest improvements.

\section{STEAIENGINES,}

(PORTABLE OR FIXTURE,)

\section{PATENT THRASHING MACHINES,}

Of the most approved makes;

\section{WINNOWING MACHINES,}

\section{AND}

CHAFF-CUTTERS OF VARIOUS KINDS.

Wire-work of every kind executed on the shortest notice.

N.B.-Agent for Milners' Fire-resisting and Thief-proof Safes. 


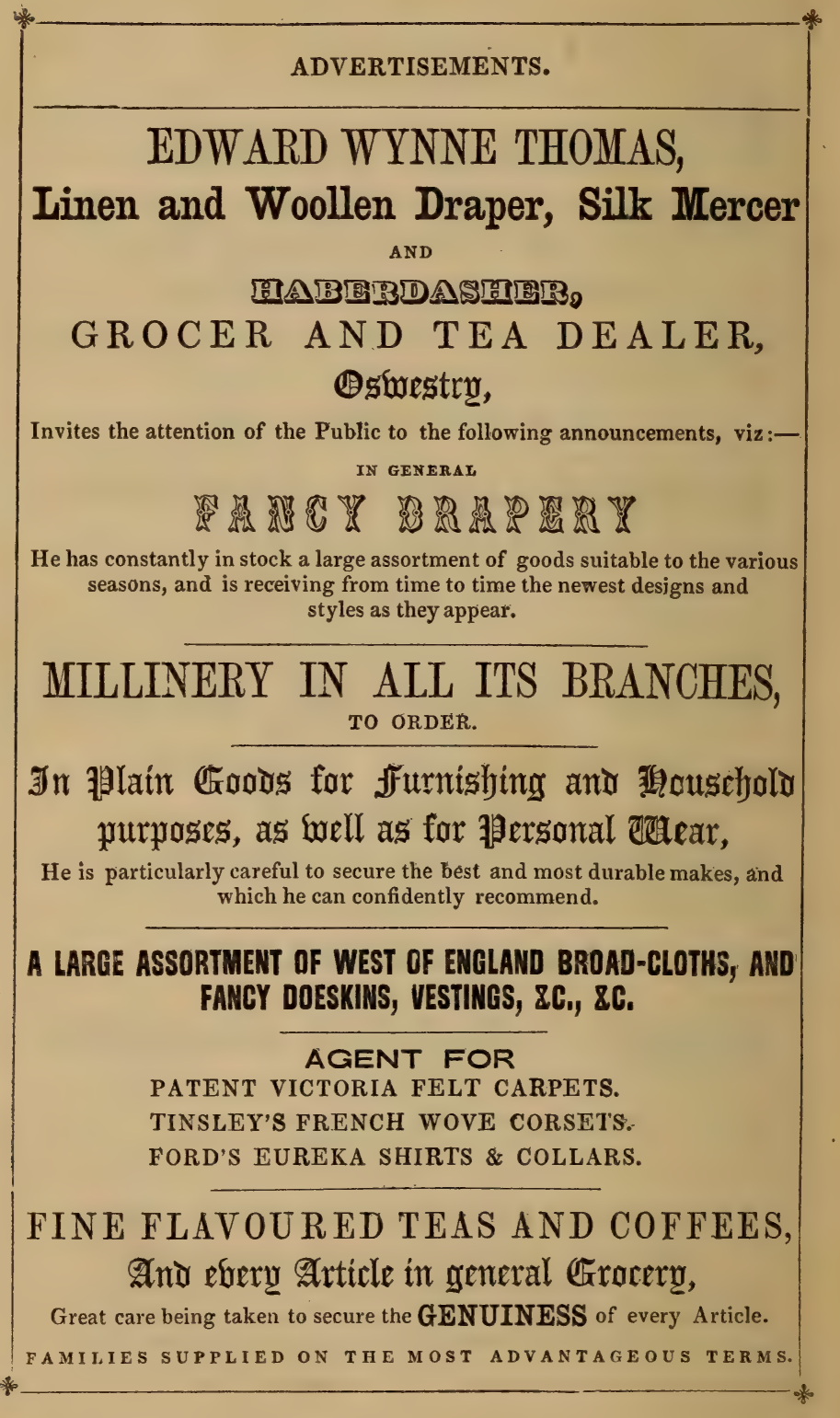


ADVEERTISEMENTS.

\section{IOCAI NEWS.}

THE ONLY NEW'PAPER THAT GIVES ALL THE LOCAL INTELLIGENCE OF THIS DISTRICT IS THE

\section{OSWESTRY ADVERTISER,}

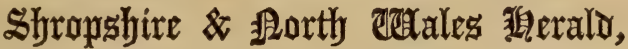

Published every Wednesday Morning.

Each number contains the London markets of Monday, and the Liverpool of Tuesday, accurately reported; a summary of General News ; Telegraphic Dispatches of Latest Intelligence; besides a quantity of Local News not to be found in any other paper. Orders for the Paper and Advertisements to be given to the Publisher,

J, ASKEW ROBERTS, BAILEY HEAD, OSWESTRY.

\section{EDWARD DAVIES,}

Confectioner, Pastry Cook, Biscuit Baker,

And Dealer in all kinds of Fancy Cheese,

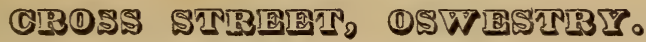

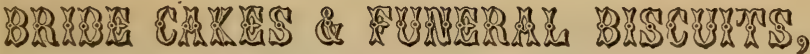

On the shortest notice.

SUPERIOR

BRITISH WINES, JAMS, JELLIES, PICKLES \& SAUCES.

Agent for the Dublin China Tea Company's Teas.

, Căstle Lansdown \& Cos. celebrated Coffees.

, Feast's Superior Calfs' Foot Jelly.

Adcock's celebrated Melton-Mowbray Pork Pies.-Oranges, Lemons, \&c.

\section{GEORGE LEWIS,}

Law Stationer and Accountant,

Zlieg Street, Oswestru. 


\section{ADVERTISEMENTS.}

\section{A. LYONS, \\ W A T CH M A KER,

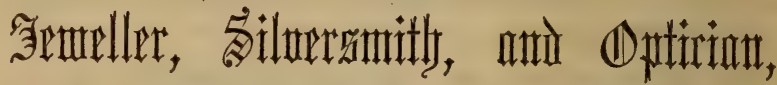

\section{LEG-STREET, OSWESTRY,}

Respectfully announces that he has constantly on sale a large assortment of

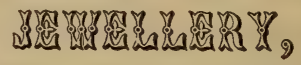

of his own and foreign manufacture; also

\section{SPECTACLES, PRESERVERS, \& EYE-GLASSES,}

To suit all sights and ages, made on the premises, with the best

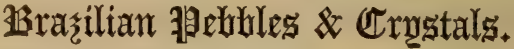

A. L. having been for many years practically engaged in the best houses on the Continent, is able to suit, at first glance, the sight of any person from the age of 10 to 70, with Spectacles or Eye-glasses.

\section{AGENT FOR ANDERSONS PATENT SPECTAGLES AND GLASSES.}

IMPORTER OF, AND DEALER IN

\section{RAVANNAR, AND OTIRIB CIGABS。}

\section{PARIS HOUSE,}

Nơ, 1, Bailen Street, and 1, ftlarket Street, (1)

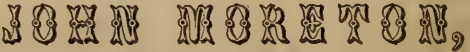

\section{IINEN \& WOOLLEN DRAPER,}

Begs to call the attention of the Public to the above establishment, where they niay rely upon being supplied with every description of LINEN \& WOOLLEN DRAPERY, of the best quality, selected from the first manufactories, and OFFERED AT THE SMALLEST REMUNERATIVE PROFIT. 




LIBRARY OF CONGRESS

|||||||||||||||||||||||||||||||||||||||||||||||||||||||||

00213990962 